

\section{Editorial Board}

\section{Editor in Chief}

Mark Zilberman, MSc, Shiny World Corporation, Toronto, Canada

\section{Scientific Editorial Board}

Viktor Andrushhenko, PhD, Professor, Academician of the Academy of Pedagogical Sciences of Ukraine, President of the Association of Rectors of pedagogical universities in Europe

John Hodge, MSc, retired, USA

Petr Makuhin, PhD, Associate Professor, Philosophy and Social Communications faculty of Omsk State Technical University, Russia

Miroslav Pardy, PhD, Associate Professor, Department of Physical Electronics, Masaryk University, Brno, Czech Republic

Lyudmila Pet'ko, Executive Editor, PhD, Associate Professor, National Pedagogical Dragomanov University, Kiev, Ukraine

\section{IntellectualArchive, volume 10, Number 3}

\begin{tabular}{|c|c|}
\hline $\begin{array}{l}\text { Publisher } \\
\text { Address }\end{array}$ & $\begin{array}{l}\text { Shiny World Corp. } \\
9200 \text { Dufferin Street } \\
\text { P.O. Box } 20097 \\
\text { Concord, Ontario } \\
\text { L4K 0C0 } \\
\text { Canada }\end{array}$ \\
\hline $\begin{array}{l}\text { E-mail } \\
\text { Web Site } \\
\text { Series } \\
\text { Frequency } \\
\text { Month } \\
\text { ISSN } \\
\text { DOI } \\
\text { Trademark }\end{array}$ & $\begin{array}{l}\text { support@IntellectualArchive.com } \\
\text { www.IntellectualArchive.com } \\
\text { Journal } \\
\text { Every } 3 \text { months } \\
\text { July - September } 2021 \\
\text { 1929-4700 } \\
\text { 10.32370/IA_2021_09 } \\
\text { IntEllectualArchiveTM }\end{array}$ \\
\hline
\end{tabular}

(C) 2021 Shiny World Corp. All Rights Reserved. No reproduction allowed without permission. Copyright and moral rights of all articles belong to the individual authors. 


\section{Intellectual Archive}

Volume 10

Number 3

July/September 2021

Table of Contents

Physics

M. Pardy

M. Pardy

J. Hodge

J. Hodge

I. Karkhut,

J. Luchko,

V. Kirichok

A. Kofanov,

N. Pavlovska,

M. Kulyk,

Y. Tereshchenko,

A. Symchuk

L. Kotlyarenko,

N. Pavlovska,

Y. Komarynska,

O. Nesen,

O. Kotliarenko

\section{G. larmolovych}

I. Kanyukova,

E. Sidorovskaya

G. Turchynova,

L. Pet'ko,

V. Grigoruk
From Classical Theory to Spin 2 Gravity

From the Galileo Free Fall String to the Principle of Equivalence

Replacing Special Relativity

22

Physics Use of Mathematics

\section{Engineering}

Numerical Studies of Deformations and Crack Propagation in Reinforced Concrete Annular Sections Under Thermopower Loads

\section{Law}

Corruption in the Economy of Ukraine

Improvement in Ukraine

\section{Philology}

The Concept of Distributivity In Old High German and Middle High German Texts ..

\section{Sociology}

Communicative Taboos in Modern Business Etiquette

\section{Education}

The Colosseum in the film «Roman Holiday» (1953) 


\section{Table of Contents (continued)}

D. Nefyodov

M. Surzhyk

N. Koresandovich

Liao Bin

A. Zhuravlova

L. Turchak
Methods of Using the Google Classroom Service in Teaching Historical Disciplines During Blended and Distance Learning ....

Conceptual Technologies of Application of Coaching Technology in Public Administration

Specifics of the Concert Master's Pedagogical Activity in the Context of Trends of Modern Art Education

Organization of Experimental Work on the Formation of Musical and Aesthetic Competence of Adolescents in Out-Of-School Art Education

\section{Art}

Social Dance as a Phenomenon of Modern Dance Practice

\section{History}

Specificity of M. Novak's Activity in the Context of the Development of Ukrainian Film Production in the Countries of North America

Manuscript Guidelines

160

\section{Toronto, July/September 2021}




\title{
From classical theory to spin 2 gravity
}

\author{
Miroslav Pardy \\ Department of Theoretical Physics and Astrophysics \\ Masaryk University \\ Kotlářská 2, 61137 Brno, Czech Republic
}

August 11, 2021

\begin{abstract}
We consider here the simple derivation of the Einstein equations by Fock. Then, we approach the way from the spin 1 fields to the spin 2 fields for massive and massless particles and we derive the gravity equations from this base. In conclusion, we discuss the principle of equivalence in classical Einstein theory and in the Schwinger spin 2 gravity.
\end{abstract}

\section{Introduction}

While the electromagnetic field was determined from the motion of charges and currents, the Einstein-Hilbert theory of gravity being the spacetime geometry was determined from presence of mass-energy and linear momentum. The corresponding equations Einstein-Hilbert equations (EHE) - determine the metric tensor of spacetime for a given arrangement of stress-energy in the spacetime. The relationship between the metric tensor and the Einstein tensor allows the EHE to be written as a set of non-linear partial differential equations. The solutions of the EHE are the components of the metric tensor. The inertial trajectories of particles and radiation (geodesics) in the resulting geometry are then calculated using the geodesic equations. As well as obeying local energy-momentum conservation, the EHE reduce to Newtons law of gravitation, where the gravitational field is weak and velocities are much less than the speed of light.

We consider here the simple derivation of the Einstein equations by Fock. Then, we approach the way from the spin 1 fields to the spin 2 fields for massive and massless particles and we derive the corresponding action for spin 2 gravity from this base.

\section{The Einstein equations derived by Fock}

There is the simple derivation of the EHE given by Fock (1964). The similar derivation was performed by Chandrasekhar (1972), Kenyon (1996), Landau et al. (1987), Rindler 
(2003) and others. Source theory derivation of Einstein equations was performed by Schwinger (1970).

It is well known that the gravity mass $M_{G}$ of some body is equal to the its inertial mass $M_{I}$, where gravity mass is a measure of a massive body to create the gravity field (or, gravity force) and the inertial mass of a massive body is a measure of the ability of the resistance of the body when it is accelerated. At present time we know, that if components of elementary particles have the same gravity and inertial masses, the body composed with such elementary particles has the identical gravity and inertial mass. There is no need to perform experimental verification. So, particle physics brilliantly confirms the identity of the inertial and gravity masses.

According to the Newton theory, the gravity potential is given by the equation

$$
U(r)=-\kappa \frac{M}{r},
$$

where $r$ is a distance from the center of mass of a body, $\kappa$ is the gravitational constant and its numerical value is in SI units 6.67430(15)10 $10^{-11} \mathrm{~m}^{3} \cdot \mathrm{kg}^{-1} \cdot \mathrm{s}^{-2}$ (CODATA, 2018).

The potential $U$ is as it is well known the solution of the Poisson equation:

$$
\Delta U(r)=-4 \pi \kappa \varrho,
$$

where $\varrho$ is the density of the distributed masses.

The problem is, what is the geometrical formulation of gravity equation (2) following from the space-time element $d s$, which has the Minkowski form in case of the special theory of relativity.

Let us postulate that the motion of a body moving in the g-field is determined by the variational principle

$$
\delta \int d s=0
$$

In order to get the Newton equation of motion, we are forced to perform the following identity:

$$
g_{00}=c^{2}-2 U=-4 \pi \kappa \varrho .
$$

The second mathematical requirement, which has also the physical meaning is the covariance of the derived equation. It means that the necessary mathematical operation are the following replacing of original symbols:

$$
U \rightarrow g_{\mu \nu}
$$

with

$$
\Delta U \rightarrow \text { Tensor equation }
$$

and

$$
\varrho \rightarrow T_{\mu \nu}
$$

where $T_{\mu \nu}$ is the tensor of energy and momentum.

In order to get the tensor generalization of eq. (2) it is necessary to construct new tensor $R_{\mu \nu}$, which is linear combination of the more complicated tensor $R_{\alpha \beta, \mu \nu}$, or

$$
R_{\mu \nu}=g^{\alpha \beta} R_{\mu \alpha, \beta \nu}
$$


and the scalar quantity $R$, which is defined by equation

$$
R=g^{\lambda \mu} R_{\lambda \mu}
$$

and construct the combination tensor $G_{\lambda \mu}$ of the form

$$
G_{\mu \nu}=R_{\mu \nu}-\frac{1}{2} g_{\mu \nu} R
$$

which has the mathematical property, that the covariant divergence of this tensor is zero, or,

$$
\nabla^{\lambda} G_{\lambda \mu}=0
$$

With regard to the fact that also the energy-momentum tensor $T_{\mu \nu}$ has the zero divergence, we can identify eq. (10) with the tensor $T_{\mu \nu}$, or

$$
R_{\mu \nu}-\frac{1}{2} g_{\mu \nu} R=-\frac{8 \pi \kappa}{c^{2}} T_{\mu \nu}
$$

where the appeared constant in the last equation is introduce to get the classical limit of the equation.

The approximate solution of the last equation is as follows

$$
d s^{2}=\left(c^{2}-2 U\right) d t^{2}-\left(1+\frac{2 U}{c^{2}}\left(d x^{2}+d y^{2}+d z^{2}\right)\right) .
$$

The space-time element (13) is able to explain the shift of the frequency of light in gravitational field and the deflection of light in the gravitational field of massive body with mass $M$.

So, we have seen that the basic mathematical form of the Einstein general relativity is the Riemann manifold specified by the metric with the physical meaning. The crucial principle is the equality of the inertial and gravitational masses.

While the derivation of the EHE is elementary, Feynman wrote that the derivation of EHE by Einstein is difficult to understand. Namely:

Einstein himself, of course, arrived at the same Lagrangian but without the help of a developed field theory, and I must admit that I have no idea how he guessed the final result. We have had troubles enough arriving at the theory - but I feel as though he had done it while swimming underwater, blindfolded, and with his hands tied behind his back! (Feynman et al., 1995).

Now the question arises, what is the the force acting on the point moving in the homogenous gravitational field. It was calculated in the 3-form as follows (Landau, et al., 1987):

$$
\mathbf{f}=\frac{m c^{2}}{\sqrt{1-\frac{v^{2}}{c^{2}}}}\left\{\operatorname{grad} \ln \sqrt{h}+\sqrt{h}\left[\frac{\mathbf{v}}{c} \operatorname{rot} \mathbf{g}\right]\right\},
$$

with (Landau, et al., 1987).

$$
h=1+\frac{2 \varphi}{c^{2}}
$$

where $\varphi$ s gravitational potential generating the acceleration $\mathbf{g}$. So, we see that it is not in the simple Newton form. 
Let us still remark that the derived Einstein equations (12) can be generalized to form the Einstein equations with the cosmological constant, or, (Einstein, 1917)

$$
R_{\mu \nu}-\frac{1}{2} g_{\mu \nu} R+\Lambda g_{\mu \nu}=-\frac{8 \pi \kappa}{c^{2}} T_{\lambda \mu}
$$

where $\Lambda$ is the new cosmological constant introduced formally, with the goal to find new form of the cosmological model and their solutions in the mathematical form. In addition to that the last equation can be still derived in order to involve so cosmological matrix (Pardy, 2018b). The new form of such equations is as follows:

$$
R_{\mu \nu}-\frac{1}{2} g_{\mu \nu} R+\left(\Lambda_{\alpha \beta} g^{\alpha \beta}\right) g_{\mu \nu}=-\frac{8 \pi \kappa}{c^{2}} T_{\mu \nu}
$$

where

$$
\Lambda_{\alpha \beta}=\left(\begin{array}{cccc}
\Lambda_{00} & \Lambda_{01} & \Lambda_{02} & \Lambda_{03} \\
\Lambda_{10} & \Lambda_{11} & \Lambda_{12} & \Lambda_{13} \\
\Lambda_{20} & \Lambda_{21} & \Lambda_{22} & \Lambda_{23} \\
\Lambda_{30} & \Lambda_{31} & \Lambda_{32} & \Lambda_{33}
\end{array}\right)
$$

The generalization of cosmology and the new deal of cosmology is then based on the Einstein-Pardy gravity equations (17) (Pardy, 2018b).

\section{The spin 1 field equations}

Spin was originally introduced as the rotation with an angular momentum of a particle around some axis. On the other hand, spin has some peculiar properties that distinguish it from orbital angular momenta: a) Spin quantum numbers may take half-integer values. b) Although the direction of its spin can be changed, an elementary particle cannot be made to spin faster or slower. c) The spin of a charged particle is associated with a magnetic dipole moment with a g-factor differing from 1 . This could only occur classically if the internal charge of the particle were distributed differently from its mass.

The conventional definition of the spin quantum number, $s$, is $s=n / 2$, where $n$ can be any non-negative integer. So, the allowed values of $\mathrm{s}$ are $0,1 / 2,1,3 / 2$, 2, etc. The value of $\mathrm{s}$ for an elementary particle depends only on the type of particle, and cannot be altered in any known way (in contrast to the spin direction).

We show that the natural construction of the field of the particles with spin 1 is presented in source theory method. The relation

$$
\left|\left\langle 0_{+} \mid 0_{-}\right\rangle\right|^{2}=\exp \{-2 \operatorname{ImW}\} \leq 1
$$

is postulated to be valid for all spin fields. Let us show here the construction of action and field equations concerning spin one.

If spin zero particles and fields are described by the scalar source, then a vector source denoted here as $J^{\mu}(x)$ can be considered as a candidate for the description of the spin 1 fields and particles. However, there exist some obstacles because source $J^{\mu}(x)$ has four components and spin one particles have only three spin possibilities. Nevertheless first, let us investigate by analogy with the spin zero fields the following form of the action for the unit spin fields:

$$
W(J)=\frac{1}{2} \int(d x)\left(d x^{\prime}\right) J^{\mu}(x) \Delta_{+}\left(x-x^{\prime}\right) J_{\mu}\left(x^{\prime}\right) .
$$


Then,

$$
\left|\left\langle 0_{+} \mid 0_{-}\right\rangle\right|^{2}=e^{i W} e^{i W^{*}}=\exp \left\{-\int d \omega_{p} J^{* \mu}(p) J_{\mu}(p)\right\}
$$

However,

$$
J^{* \mu}(p) J_{\mu}(p)=|\mathbf{J}(p)|^{2}-\left|J^{0}(p)\right|^{2} \leq 0, \quad \text { or, }>0
$$

and it means that the quantity defined by eq. (21) cannot be considered as the probability of the persistence of vacuum.

The difficulty can be overcome by replacing the original form $J^{* \mu}(x) J_{\mu}(x)$ by the following invariant structure:

$$
J^{* \mu}(p)\left[g_{\mu \nu}+\frac{1}{m^{2}} p_{\mu} p_{\nu}\right] J^{\nu}(p)
$$

which can be with regard to its invariance, determined in the rest frame of the time-like vector $p^{\mu}$, where $p^{\mu}=(m, 0,0,0)$ in the rest frame. Then, with $g_{\alpha \alpha}=(-1,1,1,1)$ we have

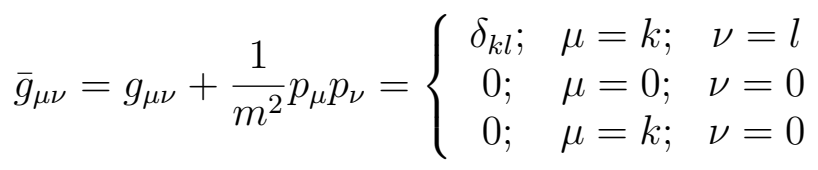

and

$$
J^{* \mu}(p) \bar{g}_{\mu \nu} J^{\nu}(p) \equiv|\mathbf{J}|^{2},
$$

and now the quantity $\left|\left\langle 0_{+} \mid 0_{-}\right\rangle\right|^{2}$ can be interpreted as the vacuum persistence probability.

At the same time $|\mathbf{J}|^{2}$ contains three independent source components, transforming among themselves under spatial rotation, as it is appropriate to unit spin.

After using eq. (23) it may be easy to get $W(J)$ in the space-time representation by the Fourier transformation, as it follows

$$
\begin{gathered}
W(J)=\frac{1}{2} \int(d x)\left(d x^{\prime}\right) \times \\
\left\{J_{\mu}(x) \Delta_{+}\left(x-x^{\prime}\right) J^{\mu}\left(x^{\prime}\right)+\frac{1}{m^{2}} \partial_{\mu} J^{\mu} \Delta_{+}\left(x-x^{\prime}\right) \partial_{\nu}^{\prime} J^{\nu}\left(x^{\prime}\right)\right\} .
\end{gathered}
$$

The field of spin one particles can be defined using the definition of the test source $\delta J^{\mu}(x)$ by the relation

$$
\delta W(J)=\int(d x) \delta J^{\mu}(x) \varphi_{\mu}(x),
$$

where $\varphi_{\mu}$ is the field of particles with spin 1 . After performing variation of the formula (26) and comparison with eq. (27) we get the equation for field of spin 1 in the following form:

$$
\varphi_{\mu}(x)=\int\left(d x^{\prime}\right) \Delta_{+}\left(x-x^{\prime}\right) J_{\mu}\left(x^{\prime}\right)-\frac{1}{m^{2}} \partial_{\mu} \int\left(d x^{\prime}\right) \Delta_{+}\left(x-x^{\prime}\right) \partial_{\nu}^{\prime} J^{\nu}\left(x^{\prime}\right) .
$$

The divergence of the vector field $\varphi_{\mu}(x)$ is given by the relation

$$
\begin{gathered}
\partial_{\mu} \varphi^{\mu}(x)=\int\left(d x^{\prime}\right) \Delta_{+}\left(x-x^{\prime}\right) \partial_{\mu}^{\prime} J^{\mu}\left(x^{\prime}\right)- \\
\frac{1}{m^{2}} \partial^{2} \Delta_{+}\left(x-x^{\prime}\right) \partial_{\nu}^{\prime} J^{\nu}\left(x^{\prime}\right)=\frac{1}{m^{2}} \partial_{\mu} J^{\nu}(x),
\end{gathered}
$$


where we used relation $-\partial^{2} \Delta_{+}=\delta\left(x-x^{\prime}\right)-m^{2} \Delta_{+}$.

Further, we have after applying operator $\left(-\partial^{2}+m^{2}\right)$ on the equation (28) the following equation:

$$
\begin{gathered}
\left(-\partial^{2}+m^{2}\right) \varphi_{\mu}(x)=J_{\mu}(x)-\frac{1}{m^{2}} \partial_{\mu} \partial_{\nu} J^{\nu}(x) \\
\left(-\partial^{2}+m^{2}\right) \varphi_{\mu}(x)+\partial_{\mu} \partial_{\nu} \varphi^{\nu}(x)=J_{\mu}(x)
\end{gathered}
$$

as a consequence of eq. (29).

It may be easy to cast the last equation into the following form

$$
\partial^{\nu} G_{\mu \nu}+m^{2} \varphi_{\mu}=J_{\mu}
$$

where

$$
G_{\mu \nu}(x)=-G_{\nu \mu}(x)=\partial_{\mu} \varphi_{\nu}-\partial_{\nu} \varphi_{\mu}
$$

Identifying $G_{\mu \nu}$ with $F_{\mu \nu}$ of the electromagnetic field we get instead of eq. (32) so called the Proca equation for the electromagnetic field with the massive photon.

It is evident that the zero mass limit does not exist for $\partial_{\mu} J^{\mu}(x) \neq 0$. In such a way we are forced to redefine action $W(J)$. One of the possibilities is to put

$$
\partial_{\mu} J^{\mu}(x)=m K(x)
$$

and identify $K(x)$ in the limit $m \rightarrow 0$ with the source of massless spin zero particles.

Since the zero mass particles with zero spin are experimentally unknown in any event, we take $K(x)=0$ and we write

$$
W_{[m=0]}(J)=\frac{1}{2} \int(d x)\left(d x^{\prime}\right) J_{\mu}(x) D_{+}\left(x-x^{\prime}\right) J^{\mu}\left(x^{\prime}\right),
$$

where

$$
\partial_{\mu} J^{\mu}(x)=0
$$

and

$$
D_{+}\left(x-x^{\prime}\right)=\Delta_{+}\left(x-x^{\prime} ; m=0\right) .
$$

The detail discussion concerning helicity, angular momentum, etc. of this new particle (photon) can be found in the Schwinger book (Schwinger, 1970).

\section{Spin 2 fields}

Exploiting the experience with spin 1 fields we form the combinations

$$
\begin{gathered}
T_{\mu \nu}(x), \\
\partial_{\mu} T^{\mu \nu}(x), \\
\partial_{\mu} \partial_{\nu} T^{\mu \nu}(x)
\end{gathered}
$$

and $T(x)$ with appropriate coefficients in order to get the plausible form of action $W(T)$ for particles with spin 2 . 
While the spin one particles are described by the four-vector fields and sources the possible mathematical object describing particles with spin 2 should be the tensor field $\varphi_{\mu \nu}$ and the tensor source $T_{\mu \nu}$. Let us suppose that the tensor source is symmetrical, or, $T_{\mu \nu}=T_{\nu \mu}$.

Then, it has ten independent components. The vector source

$$
\partial_{\mu} T^{\mu \nu}(x)
$$

has $3+1$ components and the scalar source

$$
T(x)=g_{\mu \nu} T^{\mu \nu}(x)
$$

is the one-component object. If we eliminate them, then the multiplicity of the system will be equal to five and this situation corresponds to the particle with spin 2 .

Now, the question arises, what is the mathematical structure of the action $W(T)$ for particles with spin 2. Exploiting the experience with spin 1 fields we observe that $W(J)$ as the scalar quantity is formed by suitable combinations of sources and their derivatives. Similarly, in case with spin 2 particles we use the combinations of $T_{\mu \nu}(x), \partial_{\mu} T^{\mu \nu}(x), \partial_{\mu} \partial_{\nu} T^{\mu \nu}(x)$ and $T(x)$ with appropriate coefficients. The plausible form of $W(T)$ for particles with spin 2 is as follows:

$$
\begin{gathered}
W(T)=\frac{1}{2} \int(d x)\left(d x^{\prime}\right)\left\{T^{\mu \nu}(x) \Delta_{+}\left(x-x^{\prime}\right) T_{\mu \nu}(x)+\right. \\
\frac{2}{m^{2}} \partial_{\nu} T^{\mu \nu}(x) \Delta_{+}\left(x-x^{\prime}\right) \partial^{\prime \lambda} T_{\mu \lambda}\left(x^{\prime}\right)+ \\
\frac{1}{m^{4}} \partial_{\mu} \partial_{\nu} T^{\mu \nu}(x) \Delta_{+}\left(x-x^{\prime}\right) \partial_{\alpha}^{\prime} \partial_{\beta}^{\prime} T^{\alpha \beta}\left(x^{\prime}\right)- \\
\left.\frac{1}{3}\left(T(x)-\frac{1}{m^{2}} \partial_{\mu} \partial_{\nu} T^{\mu \nu}(x)\right) \Delta_{+}\left(x-x^{\prime}\right)\left(T\left(x^{\prime}\right)-\frac{1}{m^{2}} \partial_{\alpha}^{\prime} \partial_{\beta}^{\prime} T^{\alpha \beta}\left(x^{\prime}\right)\right)\right\},
\end{gathered}
$$

where the coefficients follow (as we will see in the next text) from the probability condition $\left|\left\langle 0_{+} \mid 0_{-}\right\rangle\right|^{2} \leq 1$

The probability of the vacuum persistence generated by action (43) calculated in the momentum space is of the form:

$$
\left|\left\langle 0_{+} \mid 0_{-}\right\rangle\right|^{2}=\exp \left\{-\int d \omega_{p} T^{* \mu \nu}(p) \Pi_{\mu \nu, \alpha \beta}(p) T^{\alpha \beta}(p)\right\},
$$

where (Schwinger, 1970):

$$
\Pi_{\mu \nu, \alpha \beta}(p)=\frac{1}{2}\left[\bar{g}_{\mu \alpha} \bar{g}_{\nu \beta}+\bar{g}_{\nu \alpha} \bar{g}_{\mu \beta}\right]-\frac{1}{3} \bar{g}_{\mu \nu} \bar{g}_{\alpha \beta}
$$

with

$$
\bar{g}_{\mu \nu}=g_{\mu \nu}+\frac{1}{m^{2}} p_{m u} p_{n u}
$$

being the invariant tensor.

It may be easy to calculate $T^{*} \Pi T$ in the rest frame of $p_{\mu}$ where 


$$
\bar{g}_{\mu \nu} \rightarrow \delta_{k l}
$$

Under this condition it is

$$
T^{*} \Pi T \rightarrow \bar{T}^{* k l} \bar{T}^{k l} \geq 0 ; \quad k, l \neq 0,
$$

where

$$
\bar{T}^{\mu \nu}=T^{\mu \nu}-\frac{1}{3} g^{\mu \nu} \bar{g}_{\varrho \sigma} T^{\varrho \sigma}
$$

and the following relations have been used:

$$
\begin{gathered}
\bar{g}_{\mu \nu} \bar{T}^{\mu \nu}=0 \\
p^{\mu} \bar{g}_{\mu \nu}=0 \\
\bar{g}^{\mu \nu} \bar{g}_{\mu \nu}=0 .
\end{gathered}
$$

By analogy with spin 1 fields we define the spin 2 field $\varphi_{\mu \nu}(x)$ by relation

$$
\delta W(T)=\int(d x) \delta T^{\mu \nu}(x) \varphi_{\mu \nu}(x)
$$

which can be easily transformed into momentum space as

$$
\delta W(T)=\int \frac{(d p)}{(2 \pi)^{4}} \delta T^{\mu \nu}(-p) \varphi_{\mu \nu}(p) .
$$

The symmetrical field $\varphi_{\mu \nu}(x)$ following from eq. (54) has the following form (Schwinger, 1970)

$$
\begin{array}{cc}
\varphi_{\mu \nu}(x)=\int\left(d x^{\prime}\right) \Delta_{+}\left(x-x^{\prime}\right) T_{\mu \nu}\left(x^{\prime}\right) & - \\
\frac{1}{m^{2}} \partial_{\mu} \int\left(d x^{\prime}\right) \Delta_{+}\left(x-x^{\prime}\right) \partial^{\prime \lambda} T_{\lambda \nu}\left(x^{\prime}\right) & - \\
\frac{1}{m^{2}} \partial_{\nu} \int\left(d x^{\prime}\right) \Delta_{+}\left(x-x^{\prime}\right) \partial^{\prime \lambda} T_{\mu \lambda}\left(x^{\prime}\right) & + \\
\frac{1}{m^{4}} \partial_{\mu} \partial_{\nu} \int\left(d x^{\prime}\right) \Delta_{+}\left(x-x^{\prime}\right) \partial_{\kappa}^{\prime} \partial_{\lambda}^{\prime} T^{\kappa \lambda}\left(x^{\prime}\right) & - \\
\frac{1}{3}\left(g_{\mu \nu}-\frac{1}{m^{2}} \partial_{\mu} \partial_{\nu}\right) \int\left(d x^{\prime}\right) \Delta_{+}\left(x-x^{\prime}\right) & \times \\
\left(T\left(x^{\prime}\right)-\frac{1}{m^{2}} \partial_{\kappa}^{\prime} \partial_{\lambda}^{\prime} T^{\kappa \lambda}\left(x^{\prime}\right)\right) .
\end{array}
$$

From this equation follows immediately the divergence of $\varphi_{\mu \nu}(x)$ :

$$
\partial^{\mu} \varphi_{\mu \nu}(x)=\frac{1}{m^{2}} \partial^{\mu} T_{\mu \nu}(x)-\frac{1}{3 m^{2}} \partial_{\nu}\left[T(x)-\frac{2}{m^{2}} \partial_{\kappa} \partial_{\lambda} T^{\kappa \lambda}(x)\right]
$$


and

$$
\varphi=g_{\mu \nu} \varphi^{\mu \nu}=-\frac{1}{3 m^{2}}\left[T(x)+\frac{2}{m^{2}} \partial_{\kappa} \partial_{\lambda} T^{\kappa \lambda}(x)\right] .
$$

The combination of eq. (56) and (57) forms

$$
\partial^{\mu} \varphi_{\mu \nu}(x)-\partial_{\nu} \varphi=\frac{1}{m^{2}} \partial^{\mu} T_{\mu \nu}(x)
$$

The differential equation following from eq. (55) is of the form:

$$
\begin{gathered}
\left(-\partial^{2}+m^{2}\right) \varphi_{\mu \nu}(x)=T_{\mu \nu}(x)- \\
\frac{1}{m^{2}}\left[\partial_{\mu} \partial^{\lambda} T_{\lambda \nu}(x)+\partial_{\nu} \partial^{\lambda} T_{\mu \lambda}(x)\right]+g_{\mu \nu} \frac{1}{m^{2}} \partial_{\kappa} \partial_{\lambda} T^{\kappa \lambda}(x)- \\
\frac{1}{3}\left(g_{\mu \nu}-\frac{1}{m^{2}} \partial_{\mu} \partial_{\nu}\right)\left[T(x)+\frac{2}{m^{2}} \partial_{\kappa} \partial_{\lambda} T^{\kappa \lambda}(x)\right]
\end{gathered}
$$

If we replace the scalar and vector combinations of sources in eq. (59) by the field objects from eqs. (56)-(58), we get the following differential equation for $\varphi_{\mu \nu}$ :

$$
\begin{gathered}
\left(-\partial^{2}+m^{2}\right) \varphi_{\mu \nu}+\partial_{\mu} \partial^{\lambda} \varphi_{\lambda \nu}(x)+\partial_{\nu} \partial^{\lambda} \varphi_{\mu \lambda}(x)-\partial_{\mu} \partial_{\nu} \varphi(x)- \\
g_{\mu \nu}\left[\left(-\partial^{2}+m^{2}\right) \varphi(x)+\partial_{\kappa} \partial_{\lambda} \varphi^{\kappa \lambda}(x)\right]=T_{\mu \nu}(x),
\end{gathered}
$$

which also follows from $\delta W(T)=0$, where

$$
W(T)=\int(d x)\left[T^{\mu \nu}(x) \varphi_{\mu \nu}(x)+£\right],
$$

where $£$ is the Lagrange function and it has the following mathematical structure:

$$
\begin{gathered}
£=-\frac{1}{2}\left[\partial^{\alpha} \varphi^{\mu \nu}(x) \partial_{\alpha} \varphi_{\mu \nu}(x)+m^{2} \varphi^{\mu \nu}(x) \varphi_{\mu \nu}(x)-\right. \\
\left.\partial^{\alpha} \varphi(x) \partial_{\alpha} \varphi(x)-m^{2} \varphi^{2}(x)\right]- \\
\partial_{\mu} \varphi^{\mu \nu}(x) \partial_{\nu} \varphi(x)+\partial_{\mu} \varphi^{\mu \nu}(x)+\partial_{\mu} \varphi^{\mu \nu}(x) \partial^{\alpha} \varphi_{\alpha \nu}(x) .
\end{gathered}
$$

If we take the spur of eq. (60), we get

$$
\left(-\partial^{2}+m^{2}\right) \varphi(x)+\partial_{\mu} \partial_{\nu} \varphi^{\mu \nu}(x)=-\frac{1}{2}\left[T(x)+m^{2} \varphi(x)\right] .
$$

After inserting eq. (63) into eq. (60), we get

$$
\begin{gathered}
\left(-\partial^{2}+m^{2}\right) \varphi_{\mu \nu}(x)+\partial_{\mu} \partial^{\lambda} \varphi_{\lambda \nu}(x)+\partial_{\nu} \partial^{\lambda} \varphi_{\mu \lambda}(x)- \\
\partial_{\mu} \partial_{\nu} \varphi(x)+g_{\mu \nu} \frac{m^{2}}{2} \varphi(x)=T_{\mu \nu}(x)-\frac{1}{2} g_{\mu \nu} T(x) .
\end{gathered}
$$

Introducing 


$$
G_{\mu \lambda \nu}(x)=-G_{\nu \lambda \mu}(x)=\partial_{\mu} \varphi_{\lambda \nu}(x)-\partial_{\nu} \varphi_{\lambda \mu}(x)
$$

we can write eq. (64) in the following form:

$$
\begin{gathered}
\partial^{\lambda} G_{\mu \nu \lambda}(x)-\partial_{\nu} G_{\mu \lambda}^{\lambda}(x)+m^{2}\left[\varphi_{m u \nu}(x)+\frac{1}{2} g_{\mu \nu} \varphi(x)\right]= \\
T_{\mu \nu}(x)-\frac{1}{2} g_{\mu \nu} T(x) .
\end{gathered}
$$

Further relations concerning spin 2 fields can be found in monograph by Schwinger (1970).

\section{The massless limit of the spin 2 theory}

It is evident that in order action (43) continue to exist in the limit $m \rightarrow 0$ it is natural to put

$$
\partial_{\nu} T^{\mu \nu}(x)=\frac{m}{\sqrt{2}} J^{\mu}(x)
$$

and

$$
\partial_{\mu} J^{\mu}(x)=m\left[\sqrt{3} K(x)-\frac{1}{\sqrt{2}} T(x)\right],
$$

where $J^{\mu}(x)$ and $K(x)$ are independent sources. The independence of them is expressed by constants $\sqrt{3}$ and $1 / \sqrt{2}$ which are chosen to eliminate any coupling between sources $K(x)$ and $T(x)$. After insertion of eqs. (67) and (68) into action (43), we get for $m \rightarrow 0$ :

$$
\begin{gathered}
W(T)=\frac{1}{2} \int(d x)\left(d x^{\prime}\right)\left\{T^{\mu \nu}(x) D_{+}\left(x-x^{\prime}\right) T_{\mu \nu}(x)-\right. \\
\frac{1}{2} T(x) D_{+}\left(x-x^{\prime}\right) T\left(x^{\prime}\right)+J^{\mu}(x) D_{+}\left(x-x^{\prime}\right) J_{\mu}\left(x^{\prime}\right)+ \\
\left.K(x) D_{+}\left(x-x^{\prime}\right) K\left(x^{\prime}\right)\right\}
\end{gathered}
$$

where $D_{+}\left(x-x^{\prime}\right)=\Delta_{+}\left(x-x^{\prime} ; m=0\right)$ and for $m=0$

$$
\begin{gathered}
\partial_{\mu} T^{\mu \nu}(x)=0 \\
\partial_{\mu} J^{\mu}(x)=0 .
\end{gathered}
$$

The formula (69) represents the invariant decomposition by means of sources of massless particles with spin 2, 1 and 0 . The massless particles of helicity \pm 2 is called graviton and the action which corresponds to this particle follows from action (69) in the form

$$
W(T)=\frac{1}{2} \int(d x)\left(d x^{\prime}\right)\left\{T^{\mu \nu}(x) D_{+}\left(x-x^{\prime}\right) T_{\mu \nu}(x)-\right.
$$




$$
\left.\frac{1}{2} T(x) D_{+}\left(x-x^{\prime}\right) T\left(x^{\prime}\right)\right\}
$$

with

$$
\partial_{\mu} T^{\mu \nu}(x)=0 .
$$

The graviton is the particle which was not hitherto experimentally discovered. Nevertheless, we can suppose it is the mediate boson which initiates the gravitational phenomena, just as the photon initiates the electromagnetic ones.

The source restriction $\partial_{\mu} T^{\mu \nu}(x)=0$ for the graviton source states the existence of a conservation law of the vector

$$
p^{\nu}=\int d \sigma_{\mu} T^{\mu \nu}(x)
$$

where $d \sigma_{\mu}$ is an invariant element of area, which can be identified with the energymomentum vector. The connection between the mechanical tensor $T_{m e c h}^{\mu \nu}$ and the gravitational tensor $T_{\text {grav }}^{\mu \nu}$ is postulated by relation

$$
T_{\text {grav }}^{\mu \nu}=\kappa^{1 / 2} T_{m e c h}^{\mu \nu},
$$

where $\kappa$ is the gravitational constant of the magnitude

$$
\kappa=8 \pi G,
$$

where $6.67430(15) 10^{-11} \mathrm{~m}^{3} \cdot \mathrm{kg}^{-1} \cdot \mathrm{s}^{-2}$ (CODATA, 2018).

The action corresponding to the gravitational field initiated by the mechanical tensor $T_{\text {mech }}^{\mu}$ is now

$$
\begin{gathered}
W(T)=\frac{\kappa}{2} \int(d x)\left(d x^{\prime}\right)\left\{T^{\mu \nu}(x) D_{+}\left(x-x^{\prime}\right) T^{\mu \nu}(x)-\right. \\
\left.\frac{1}{2} T(x) D_{+}\left(x-x^{\prime}\right) T\left(x^{\prime}\right)\right\}
\end{gathered}
$$

with

$$
\partial_{\mu} T^{\mu \nu}(x)=0
$$

The corresponding gravitational field definition is

$$
\delta W(T)=\int(d x) \delta T^{\mu \nu} h_{\mu \nu},
$$

which implies the field equation for $h_{\mu \nu}(x)$ in the following form:

$$
\begin{gathered}
-\partial^{2} h_{\mu \nu}(x)+\partial_{\mu} \partial^{\alpha} h_{\alpha \nu}(x)+\partial_{\nu} \partial^{\alpha} h_{\mu \alpha}(x)-\partial_{\mu} \partial_{\nu} h(x)= \\
\kappa\left(T_{\mu \nu}(x)-\frac{1}{2} g_{\mu \nu} T(x)\right)
\end{gathered}
$$

with

$$
T(x)=g_{\mu \nu} T^{\mu \nu}(x)
$$




$$
h(x)=g_{\mu \nu} h^{\mu \nu}(x) .
$$

Let us remark that action (77) was used by author to determination of the spectral form of the emitted gravitons by the binary system and by the related systems (Pardy, 1983; 1994a; 1994b; 1994c; 1994d; 2011; 2018a; 2019). Action (77) enables also the derivation of the Newton gravity potential and Einstein gravity field equations (Schwinger, 1970; Pardy, 1984). After the verbal investigation of the Schwinger book involving theory of gravity (Schwinger, 1970), we can honestly say that the words principle of equivalence are not involved in his book.

\section{Discussion}

We have seen that the Einstein equivalence principle was not used in the Schwinger spin 2 gravity. Einstein formulated this principle with two reference frames, $\mathrm{K}$ and $\mathrm{K}$ ' where $\mathrm{K}$ is a uniform gravitational field, whereas $\mathrm{K}^{\prime}$ has no gravitational field. It is uniformly accelerated in such a way that objects in the two frames experience identical forces. According to Einstein systems K and K' are physically exactly equivalent. This assumption of exact physical equivalence makes it impossible to speak of the absolute acceleration of the system of reference, just as the usual theory of relativity forbids to talk of the absolute velocity of a system. It makes the equal falling of all bodies in a gravitational field (Einstein, 1911).

Or, Inertia and gravity are identical; hence and from the results of special relativity theory it inevitably follows that the symmetric fundamental tensor $g_{\mu \nu}$ determines the metric properties of space, of the motion of bodies due to inertia in it, and, also, the influence of gravity (Einstein, 1918).

According to Fock (1964), principle of equivalence is understood to be the statement that in some sense a field of acceleration is equivalent to a gravitational field. It means that by introducing a suitable system of coordinates (which is usually interpreted as an accelerated frame of reference) one can so transform the equations of motion of a mass point in a gravitational field that in this new system they will have the appearance of equations of motion of a free mass point. Thus a gravitational field can, so to speak, be replaced, or rather imitated, by a field of acceleration. Owing to the equality of inertial and gravitational mass such a transformation is the same for any value of the mass of the particle. But it will succeed in its purpose only in an infinitesimal region of space, i.e. it will be strictly local. In the general case the transformation described corresponds mathematically to passing to a locally geodesic system of coordinates.

The principle of equivalence states that it is impossible to distinguish between the action on a particle of matter of a constant acceleration, or, of static support in a gravitational field (Lyle, 2008). We have seen that Schwinger theory does not use the principle of equivalence.

The controversions between different opinions on the principle of equivalence can be easily solved by the physical definition of gravity and inertia. Namely: gravity is the specific form of matter, or, form of vacuum. And inertia is the interaction of the massive body with vacuum which is the physical medium. So, Gravity is form of matter and inertia is form of interaction. 


\section{References}

Chandrasekhar, S. (1972). On the "Derivation" of Einstein's Field Equations, AJP 40, No. 2, pp. $224-234$.

Einstein, A. (1911). Über den Einflus der Schwerkraft auf die Ausbreitung des Lichtes, Ann. Phys. 1911, 35, 898-908. ibid. On the Influence of Gravitation on the Propagation of Light, Vol. 3, Doc. 23, 485-497 (Einstein 1911h).

Einstein, A. (1917). Kosmologische Betrachtungen zur allgemeinen Relativitaetstheorie, Sitzungsberichte der Königlich Preussischen Akademie der Wissenschaften Berlin. part 1: $142-152$.

Einstein, A. (1918). Principieless zur allgemeinen Relativitätstheorie, Ann. Phys. 1918, 55, 241-244. ibid. On the Foundations of the General Theory of Relativity Vol. 7, Doc. 4, 37-44 (Einstein 1918e).

Feynman, R., Morinigo, F. B. and Wagner, W. B. Feynman Lectures on Gravitation, (Pinguin Books, London, 1995).

Fock, V. Theory of space, time and and gravitation, Second revised ed., (Pergamon Press, Oxford, London, ... 1964).

Kenyon, I. R. General Relativity, (Oxford University Press Inc. New York, 2-nd ed., 1996).

Landau, L. D. and Lifshitz, E. M. The Classical Theory of Fields, Fourth Revised English Edition, (Amsterdam, Boston, Heidelberg, London, ..., 1987).

Lyle, S. N. Uniformly Accelerating Charged Particles. A Threat to the Equivalence Principle, (Springer-Verlag, Berlin, Heidelberg, 2008).

Pardy, M. (1983). The synchrotron production of gravitons by the binary system, GRG 15, No. 11, 1027.

Pardy, M. Source methods in gravity, (FOLIA, Facultatis Scientiarum Naturalium Universitatis Purkynianae Brunensis, XXIV, 1984).

Pardy, M. (1994a). The High-energy gravitons from the binary: Preprint: CERN-TH. $7239 / 94$.

Pardy, M. (1994b). The quantum energy loss of a binary system: CERN-TH. 7299/94.

Pardy, M. (1994c). The gravitational Cerenkov radiation with radiative corrections: CERN-TH.7270/94.

Pardy, M. (1994d). The gravitational Čerenkov radiation with radiative corrections: Phys. Lett. B 336, 362.

Pardy, M. (2011). The radiation of the gravitational and electromagnetic binary pulsars; pp. 97-123. in: Pulsars: Discoveries, Functions and Formation (Editors: Peter A. Travelle, Nova Science Publishers, Series: Space Science).

Pardy, M. (2018a). The black hole binary gravitons and thermodynamics, viXra: $1810.0304 \mathrm{v} 1$. 
Pardy, M. (1918b). Einstein Equations with Cosmological Matrix, Intell. Arch., ID 1994, 2018-10-31

Pardy, M. The Black Hole Binary Gravitons and Related Problems. Book title: New Ideas Concerning Black Holes and the Evolution of the Universe, (IntechOpen, 2019).

Rindler, W. Relativity, Special, General and Cosmological, (Oxford University Press, 2003).

Schwinger, J. Particles, Sources and Fields, (Addison-Wesley Publishing Company, Reading, Mass., 1970). 


\title{
From the Galileo Free Fall String to the Principle of Equivalence
}

\author{
Miroslav Pardy \\ Department of Physical Electronics \\ Masaryk University \\ Kotlářská 2, 61137 Brno, Czech Republic \\ e-mail:pamir@physics.muni.cz
}

September 17, 2021

\begin{abstract}
We consider the string with the length $l$, the left end and the right end of which is non relativistically accelerated by the constant acceleration $a$. We calculate the motion of such string and then the motion of the Galileo free fall string in gravity. The solutions are not identical. So, we distinguish between noninertial field and the gravity field and we discuss the principle of equivalence. In conclusion we suggest to drop charged objects from the very high tower Burj Khalifa in order to say crucial words on the principle of equivalence.
\end{abstract}

\section{Introduction}

It is well known that Galileo performed experiment in Pisa - later the famous experiment - with the result that the every falling body is falling with a uniform acceleration, the resistance of the medium being through which it was falling remained negligible. He also derived the correct kinematic law for the distance traveled during a uniform acceleration starting from rest, namely, that it is proportional to the square of the elapsed time. Prior to Galileo, Nicole Oresme, in the 14-th century, had derived the times-squared law for uniformly accelerated body, and Domingo de Soto had suggested in the 16-th century that bodies falling through a homogeneous medium would be uniformly accelerated. Soto, however, did not recognize the strictly uniform acceleration is only in a vacuum, and that it would otherwise eventually reach a uniform terminal velocity. Galileo expressed the time-squared law using geometrical constructions and mathematically precise words.

We here repeat the Galileo experiment in the generalized mathematical form. Namely with the string. We discuss the motion of the string accelerated by the Newton forces 
and by gravity and we discover substantial differences leading to the philosophy of the principle of equivalence.

\section{The uniformly accelerated string}

Let us consider the string with the length $l$, the left end of which is accelerated by the constant acceleration $a$ and the right end is accelerated also by the constant acceleration a.

Our problem is described by the wave equation (Koshlyakov, et al., 1962)

$$
u_{t t}=c^{2} u_{x x}+g(x, t)
$$

with the boundary conditions

$$
\begin{gathered}
u(x=0)=\kappa_{1}(t)=\frac{1}{2} a t^{2} \\
u(x=l)=\kappa_{2}(t)=\frac{1}{2} a t^{2}+l=\kappa_{1}(t)+l
\end{gathered}
$$

and with the initial conditions

$$
u(t=0)=f(x) ; \quad u_{t}(t=0)=F(x) .
$$

The problem cannot be solved by the standard Fourier method because the boundary conditions (2)-(3) are not homogenous. So, we introduce the auxiliary function (Koshlyakov et al., 1962)

$$
w(x, t)=\kappa_{1}(t)+\left[\kappa_{2}(t)-\kappa_{1}(t)\right] \frac{x}{l}
$$

with the boundary conditions

$$
w(x=0)=\kappa_{1}(t) ; \quad w(x=l)=\kappa_{1}(t)+l
$$

and the final solution we find in the form:

$$
u(x, t)=v(x, t)+w(x, t)
$$

with the boundary conditions

$$
v(x=0)=0 ; \quad v(x=l)=0
$$

and the initial conditions

$$
v(t=0)=f_{1}(x) ; \quad v_{t}(t=0)=F_{1}(x) .
$$

After insertion of $u=v+w$ into eq. (1), we get the following equation for $v$ and $w$ :

$$
v_{t t}=c^{2} v_{x x}+g(x, t)+c^{2} w_{x x}-w_{t t} .
$$

Then, if we use the definition of $w$ by eq. (5), we get equation for $v$ in the form:

$$
v_{t t}=c^{2} v_{x x}+g_{1}(x, t)
$$


where

$$
g_{1}(x, t)=g(x, t)-\kappa_{1}^{\prime \prime}(t)-\left[\kappa_{2}^{\prime \prime}(t)-\kappa_{1}^{\prime \prime}(t)\right] \frac{x}{l} .
$$

So, we see, that the last algebraic procedures lead to new system of equations. Namely:

$$
v_{t t}=c^{2} v_{x x}+g_{1}(x, t)
$$

with

$$
v(x=0)=0 ; \quad v(x=l)=0
$$

and

$$
v(t=0)=f_{1}(x) ; \quad v_{t}(t=0)=F_{1}(x) .
$$

It is easy to show that $g_{1}(x, t)=g-a$ and the system of equation to be solved is as follows:

$$
v_{t t}=c^{2} v_{x x}+g-a
$$

with

$$
v(x=0)=0 ; \quad v(x=l)=0
$$

and

$$
v(t=0)=f_{1}(x)=0 ; \quad v_{t}(t=0)=F_{1}(x)=0 .
$$

The solution of the system is well known (Koshlyakov et al., 1962) and so we write the final form:

$$
v(x, t)=\sum_{k=1}^{\infty} T_{k} \sin \left(\frac{k \pi x}{l}\right)
$$

where

$$
T_{k}(t)=\frac{2}{l \omega_{k}} \int_{0}^{t} d \tau \int_{0}^{l} G(\xi, \tau) \sin \omega_{k}(t-\tau) \sin \left(\frac{k \pi \xi}{l}\right) d \xi
$$

where

$$
\omega_{k}=\frac{k \pi c}{l} ; \quad G(\xi, \tau)=g-a
$$

\section{The Free fall of the string in gravity}

Let us consider the string with length $l$, the upper end is hanged in the gravity with the acceleration $g$ and the second end is free at time $t=0$. So the mathematical formulation of the problem is as follows (Koshlyakov, et al., 1962):

$$
u_{t t}=c^{2} u_{x x}+g
$$

with

$$
\begin{array}{ll}
u(x=0)=0 ; & u_{x}(x=l)=0 \\
u(t=0)=0 ; & u_{t}(t=0)=0 .
\end{array}
$$


Putting $u=v+w$, we get for $w$ the obligate system of equations:

$$
w_{t t}=c^{2} w_{x x}
$$

with the boundary conditions

$$
w(x=0)=0 ; \quad w_{x}(x=l)=0
$$

and the initial conditions

$$
w(t=0)=-v(t=0) ; \quad w_{t}(t=0)=-v_{t}(t=0) .
$$

It is possible to show (Koshlyakov, et al., 1962) that

$$
v=\frac{g x(2 l-x)}{2 c^{2}} .
$$

So, we can write

$$
f(x)=\frac{g x(x-2 l)}{2 c^{2}} ; \quad F(x)=0
$$

Then, by the standard method of integration, we get

$$
\begin{gathered}
u(x, t)=\frac{g x(2 l-x)}{2 c^{2}} \\
-\frac{16 g l^{2}}{\pi^{3} c^{2}} \sum_{k=1}^{\infty} \frac{1}{(2 k+1)^{3}} \cos \left(\frac{(2 k+1) \pi a t}{2 l}\right) \sin \left(\frac{(2 k+1) \pi x}{2 l}\right)
\end{gathered}
$$

and

$$
u(x=l)=\frac{g l^{2}}{2 c^{2}}-\frac{16 g l^{2}}{\pi^{3} c^{2}} \sum_{k=1}^{\infty} \frac{(-1)^{k}}{(2 k+1)^{3}} \cos \left(\frac{(2 k+1) \pi a t}{2 l}\right) .
$$

The maximal quantity $u_{\max }$ is at point $t=2 l / c$ and so we get

$$
u_{\text {max }}=\frac{g l^{2}}{2 c^{2}}+\frac{16 g l^{2}}{\pi^{3} c^{2}} \sum_{k=1}^{\infty} \frac{(-1)^{k}}{(2 k+1)^{3}}
$$

With regard to the mathematical formula

$$
\sum_{k=1}^{\infty} \frac{(-1)^{k}}{(2 k+1)^{3}}=\frac{\pi^{3}}{32}
$$

we get

$$
u_{\max }=\frac{g l^{2}}{c^{2}} .
$$

So, the length of the string (rod) is in the interval $\left(l, l+\frac{g l^{2}}{c^{2}}\right)$. 


\section{Discussion}

We have seen how to calculate the internal motion of the uniformly accelerated nonrelativistic of the length $l$ by the Newton force and by the gravity force which is the analogue of the experiment where Galileo dropped objects from the leaning tower of Pisa. Galileo have used two bodies made of the same material, differing only in size. He had in fact stated that, if the effects of air friction could be ignored, the two bodies would reach the ground at the same time. So, he supported the conclusion that the every falling body is falling with a uniform acceleration, the resistance of the medium being negligible. Galileo experimentation represented the kernel of scientific investigation and Galileo was keen to point this out (Frova et al., 2006).

Galileo experiment can be related to the Einstein equivalence principle with two reference frames, $\mathrm{K}$ and $\mathrm{K}^{\prime}$ where $\mathrm{K}$ is a uniform gravitational field, whereas $\mathrm{K}^{\prime}$ has no gravitational field but is uniformly accelerated in such a way that objects in the two frames experience identical forces. According to Einstein systems K and K' are physically exactly equivalent. This assumption of exact physical equivalence makes it impossible to speak of the absolute acceleration of the system of reference, just as the usual theory of relativity forbids to talk of the absolute velocity of a system. It makes the equal falling of all bodies in a gravitational field (Einstein, 1911).

Or, Inertia and gravity are identical; hence and from the results of special relativity theory it inevitably follows that the symmetric fundamental tensor $g_{\mu \nu}$ determines the metric properties of space, of the motion of bodies due to inertia in it, and, also, the influence of gravity (Einstein, 1918).

According to Fock (1964), principle of equivalence is understood to be the statement that in some sense a field of acceleration is equivalent to a gravitational field. It means that by introducing a suitable system of coordinates (which is usually interpreted as an accelerated frame of reference) one can so transform the equations of motion of a mass point in a gravitational field that in this new system they will have the appearance of equations of motion of a free mass point. Thus a gravitational field can, so to speak, be replaced, or rather imitated, by a field of acceleration. Owing to the equality of inertial and gravitational mass such a transformation is the same for any value of the mass of the particle. But it will succeed in its purpose only in an infinitesimal region of space, i.e. it will be strictly local. In the general case the transformation described corresponds mathematically to passing to a locally geodesic system of coordinates.

The principle of equivalence states that it is impossible to distinguish between the action on a particle of matter of a constant acceleration, or, of static support in a gravitational field (Lyle, 2008).

We have seen that the motion of the accelerated string by the non-gravity forces differs from the motion of the string caused by the gravity with the acceleration g.

The controversions between different opinions can be easily solved with regard to the physical definition of gravity and inertia. Namely: gravity is form of matter in the physical vacuum. And inertia is the result of the interaction of the massive body with quantum vacuum being the physical medium.

It is well known that synchrotron radiation influences the motion of the electron in accelerators. The corresponding equation which describes the classical motion is so called the Lorentz-Dirac equation, which differs from the the so called Lorentz equation

$$
m c \frac{d u_{\mu}}{d s}=\frac{e}{c} F_{\mu \nu} u^{\nu}
$$


only by the additional term which describes the radiative corrections. So, the equation with the radiative term is as follows (Landau et al., 1988):

$$
m c \frac{d u_{\mu}}{d s}=\frac{e}{c} F_{\mu \nu} u^{\nu}+g_{\mu},
$$

where $u_{\mu}$ is the four-velocity and the radiative term was derived by Landau et al. in the form (Landau et al., 1988):

$$
g_{\mu}=\frac{2 e^{3}}{3 m c^{3}} \frac{\partial F_{\mu \nu}}{\partial x^{\alpha}} u^{\nu} u^{\alpha}-\frac{2 e^{4}}{3 m^{2} c^{5}} F_{\mu \alpha} F^{\beta \alpha} u_{\beta}+\frac{2 e^{4}}{3 m^{2} c^{5}}\left(F_{\alpha \beta} u^{\beta}\right)\left(F^{\alpha \gamma} u_{\gamma}\right) u_{\mu} .
$$

The last equation can be easily converted into equation for charged particle moving in gravity. However, the term describing the radiation caused by gravity is not present (Landau, et al., 1988).

It was proved by author (Pardy, 2009) that synchrotron radiation influences the spin motion of the electron in accelerators. The corresponding equation which describes the classical spin motion is so called the Bargman-Michel-Telegdi-Pardy and is of the form (Pardy, 2009):

$$
\begin{gathered}
\frac{d a_{\mu}}{d s}=2 \mu F_{\mu \nu} a^{\nu}-2 \mu^{\prime} u_{\mu} F^{\nu \lambda} u_{\nu} a_{\lambda}+ \\
\Lambda u_{\mu}\left\{\frac{2 e^{3}}{3 m c^{3}} \frac{\partial F_{\lambda \nu}}{\partial x^{\alpha}} u^{\nu} u^{\alpha}-\right. \\
\left.\frac{2 e^{4}}{3 m^{2} c^{5}} F_{\lambda \alpha} F^{\beta \alpha} u_{\beta}+\frac{2 e^{4}}{3 m^{2} c^{5}}\left(F_{\alpha \beta} u^{\beta}\right)\left(F^{\alpha \gamma} u_{\gamma}\right) u_{\lambda}\right\} a^{\lambda} .
\end{gathered}
$$

Let us remark that the conversion of this equation to the situation where the interaction with the gravitational field is present, was not still derived.

Let us remark, that free fall of the positronium is of the same law as the free fall of an electron, or, positron apart. Also, free fall of the protonium is of the same law as the free fall of the proton, or, antiproton apart. It was experimentally verified. It means that the charge interaction with gravity is zero. Gravity interact only with mass and the result of such interaction is the free fall with emission of gravitons. In case of the binary system it was confirmed by NASA and the spectral formula of the emission of gravitons by the binary was calculated by author (Pardy, 1983; 1994a; 1994b; 2011; 2018; 2019). In case of the existence of the gravitational index of refraction, the gravitational Cherenkov radiation is possible (Pardy, 1994c; 1994d).

While Galileo dropped objects from the leaning tower of Pisa, now, we have possibility to drop charged objects from the very high tower Burj Khalifa, in order to confirm the law that charged objects accelerated by the gravitational field do not radiate the electromagnetic energy. It is not excluded that such experiment with the adequate title Galileo-Pardy-Burj Khalifa project will be realized sooner, or, later. The project is cheaper than LHC.

\section{References}

Einstein, A. (1911). Über den Einflus der Schwerkraft auf die Ausbreitung des Lichtes, Ann. Phys. 1911, 35, 898-908. ibid. On the Influence of Gravitation on the Propagation of Light, Vol. 3, Doc. 23, 485-497 (Einstein 1911h). 
Einstein, A. (1918). Principieless zur allgemeinen Relativitätstheorie, Ann. Phys. 1918, 55, 241-244. ibid. On the Foundations of the General Theory of Relativity Vol. 7, Doc. 4, 37-44 (Einstein 1918e).

Fock, V. Theory of space, time and and gravitation, Second revised ed., (Pergamon Press, Oxford, London, ... 1964).

Frova, A. and Marenzana, M. Thus Spoke Galileo, The Great Scientist's Ideas and Their Relevance to the Present Day, (Oxford University Press, 2006).

Koshlyakov, N. S., Gliner, E. V. and M. M. Smirnov, The Differential Equations of Mathematical Physics. (Nauka, Moscow, 1962). (in Russian).

Landau, L. D. and Lifshitz, E. M. , The Classical Theory of Fields, Fourth Revised English Edition, (Amsterdam, Boston, Heidelberg, London, ..., 1987).

Lyle, S. N. Uniformly Accelerating Charged Particles, A Threat to the Equivalence Principle, (Springer-Verlag, Berlin, Heidelberg, 2008).

Pardy, M. (2009), The bremsstrahlung equation for the spin motion in electromagnetic field, International Journal of Theoretical Physics, Volume 48, Number 11, pp. 3241-3248; arXiv: hep-ph/0809.3888 v1, acc-ph/0801.2483.

Pardy, M. (1983). The synchrotron production of gravitons by the binary system, GRG 15, No. 11 (1983), 1027.

Pardy, M. (1994a). The High-energy gravitons from the binary: Preprint: CERN-TH. $7239 / 94$.

Pardy, M. (1994b). The quantum energy loss of a binary system: CERN-TH. 7299/94.

Pardy, M. (1994c). The gravitational Cerenkov radiation with radiative corrections: CERN-TH.7270/94.

Pardy, M. (1994d). The gravitational Čerenkov radiation with radiative corrections: Phys. Lett. B 336, 362.

Pardy, M. (2011). The radiation of the gravitational and electromagnetic binary pulsars; pp. 97-123. in: Pulsars: Discoveries, Functions and Formation (Editors: Peter A. Travelle, Nova Science Publishers, Series: Space Science).

Pardy, M. (2018). The black hole binary gravitons and thermodynamics, viXra: $1810.0304 \mathrm{v} 1$.

Pardy, M. (2019). The Black Hole Binary Gravitons and Related Problems, IntechOpen. Book title: New Ideas Concerning Black Holes and the Evolution of the Universe 


\title{
Replacing Special Relativity
}

\author{
J.C. Hodge ${ }^{1 *}$ \\ ${ }^{1}$ Retired, 477 Mincey Rd., Franklin, NC, 28734
}

\begin{abstract}
The Special Theory of Relativity applies where gravitation is insignificant. There are many observations that remain poorly explained by the standard models of either the big of cosmology or the small of Quantum mechanics. The strength of the Scalar Theory Of Everything (STOE) is its ability to describe an extremely wide range of observations and to predict observations. Each of the STOE axioms has been used in the development of models of observations in the big and the small. The axioms that replace Special Relativity are: (1) Time is an abstraction of the duration between events causing events. (2) The diameter of the hods is the same throughout the universe. (3) The distance between hods is related to plenum density $\rho$. Higher $\rho$ reduces the distance between hods. (4) The speed of photons and hods (light) is the greatest of any matter in a given environment. (5) The speed of the plenum wave is much faster than the speed of the hods. The STOE passes the tests of Special Relativity and does much more. The STOE is a major paradigm shift.
\end{abstract}

keywords: STOE, special relativity

\section{INTRODUCTION}

The theory of Special Relativity (SR) was developed from consideration of the aberration of light, Lorentz's elaborations of Maxwell's equations (independence of the speed of light $c$ of the source and observer), the moving magnet and conductor experiment, the null results of aether drift experiments, and the Fizeau experiment (suggesting the $c$ is modified to $c / n$ where $n$ is the index of refraction). Additional experiments considered to be tests of SR are the Doppler effect, the Kennedy-Thorndike like experiments (testing constancy of $c$ ) and Ives-Stilwell like experiments (testing time dilation and length contraction).

The Scalar Theory Of Everything (STOE) was developed to model cosmological problems (Hodge 2015d, 2020). Hodge (2004) posited the universe was composed of two components and their interaction. The STOE is causative, Machian, and fractal (self-similar).

The STOE application to SR started with Newton's speculations about corpuscular nature of light (Hodge 2012, 2020). A particle model of diffraction and

*E-mail: jchodge@frontier.com 


\section{INDEX OF REFRACTION}

interference must first describe "coherence" of light. Passing the light through a slit in a mask tests coherence. If the light is coherent, a diffraction pattern appears on a screen. If the light is not coherent, a diffraction pattern will not appear on a screen.

Hodge (2012) expanded on the characteristics of the plenum, hods, and their interactions to derive the STOE particle ${ }^{1}$ photon diffraction model. This photon model and a toy simulation program were developed to yield a diffraction pattern after random particle photons moved a large distance that simulated the development of coherence of light. The computer program involved several iterations, which raises the specter of chaos. However, chaos is avoided by having several feedback conditions that are also in nature. Passing the photons through a slit and matching the screen pattern to a Fraunhofer pattern demonstrated coherence. Other observations suggest the photon distribution in a laser beam and explain the Afshar Experiment (Ashar 2007).

The photon model was extended and modified to describe the single photon at a time in the experiment (Hodge 2015b,c, and references therein). This model suggested the experiments (Hodge Experiments) involving the varying illumination of coherent light across a slit(Hodge 2017b,c). The prediction was found to be consistent with the observations of Hodge Experiments. In addition, an experiment involving a transparent mask rejected wave models of light. Only the STOE model of interference was not rejected (Hodge 2019a). One of the characteristics of this model is that the $c$ varies linearly with the $\rho$ and is the highest speed that any matter (hods) may achieve. Because the $\rho$ caused by the Sun and the universe may vary locally to the photon without being in a refractive substance, this model differs from the Fizeau model.

The STOE addressed Maxwell's Equations by experiments that suggested the "moving magnet and conductor thought experiment" had a basis in a different view of the Biot-Savart Law and the magnetic field (Hodge 2018a,b,c).

This paper explores how the STOE applies to the Special Relativity basic observations. The sections of this paper discuss the aspects of Special Relativity: 2 Index of refraction

3 Null Experiments

4 Length contraction

5 Moving magnet and conductor problem

6 Clocks

7 Time dilation

8 Discussion and Conclusion.

\section{Index of refraction}

Figure 1 shows the diffraction simulation trajectories of photons (Hodge 2015a). Note the photons start to change direction toward the mask before they reach the mask. Experimenters have noted this effect. Also, the speed of light changed

\footnotetext{
${ }^{1} \mathrm{~A}$ distinction is made between a wave packet type model that is called a "photon" and a particle type model.
} 


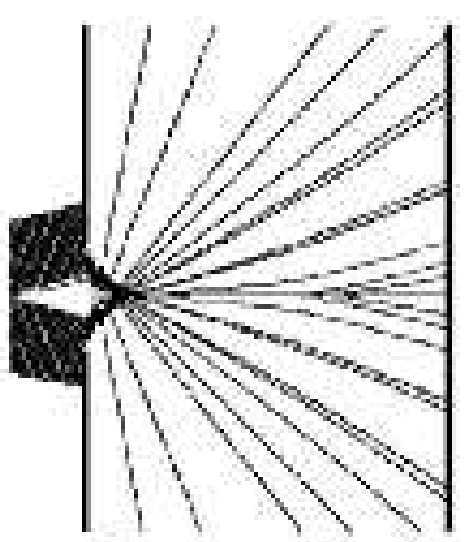

Figure 1: Photon diffraction simulation from Hodge (2015a).

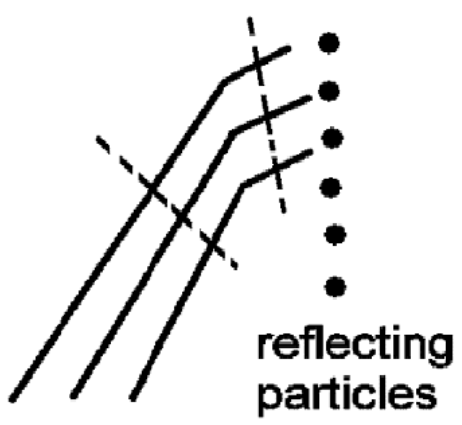

Figure 2: Index of refraction starts before photons enter the new media.

in the slit (Verdad 2019). This is consistent with the unexplained observation that the light beam changes direction immediately before entering a different medium such as from air to glass, see Fig. 2.

Light from distant objects (stars) achieves coherence. The STOE model of this was demonstrated in a computer simulation (Hodge 2012). The part of the model that produced coherence is that each particle causes a variation in the $\rho$ field. The other photons then travel faster or slower depending on the $\rho$ as depicted if Fig. 3. The Shapiro delay is interpreted to mean the lower $\rho$ closer to bodies causes a lower speed of photons. Higher $\rho$ causes faster photon speeds.

The photons/bodies in a trough also reinforce the trough for other photons. Thus, the photons tend to align in bunches which are coherent as diagramed in Figs. $4 ; 5 ; 6$; and 7 .

The model of a photon (Hodge 2012) included the simulation of how a random distribution of photons become coherent with distance traveled. The forces on the photons force them to become organized in accordance with the number of hods (frequency) in a photon as depicted in Figs. 4. The speed of photons is the fastest that matter can travel in any environment. If the source is moving away from the direction of previously emitted photons, the rate spacing of the photons becomes longer Fig. 5. The spacing of the bunches changes. The STOE suggests the forces on the photon tend toward becoming coherent. The addition of hods to matter particles has been assumed for galaxy redshift, the Doppler effect, and for the generation of the magnetic field of electromagnetic waves of photons. They become coherent by attracting free hods or by ejecting hods during their travel. The coherent grouping is reestablished (see Figs. 6 and 7).

A distinction is made between the velocity of an object such as hods that depends on the environment $(\rho$ and $n$ ) along its path and the velocity of an object such as bullets and balls that depend on the velocity of the source. 


\section{NULL EXPERIMENTS}

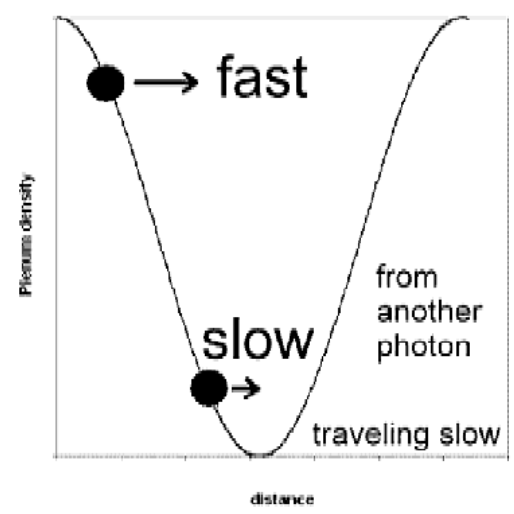

Figure 3: Photons change speed depending on $\rho$ from Hodge (2012).

The Fizeau experiment demonstrated the speed of light $c$ is higher in the direction of fluid flow and slower against the fluid flow. This is the same mechanism. That is, the immediate environment of the photon determines the photon's trajectory. This effect is called "carry-along".

Carry-along is not a drag effect. Carry-along derives from a necessary condition in the toy simulation to produce photon interference. The concept of "drag" refers to a major body such as the Earth dragging the aether to create a co-moving situation. The carry-along is a varying plenum that causes photons to change speed amongst atoms.

\section{$3 \quad$ Null experiments}

The null experiments such as the Michelson-Morley Experiment, the Miller Experiment, and similar experiment are explained because the $\rho$ and $\vec{\nabla} \rho$ (gravity) are carried-along with the experimental apparatus. The overall $\rho$ caused by the Sun and Moon cause tides (Hodge 2019b). The changes around the experiment are too slow and may have caused the 6 P.M. observations to be slightly higher than the noon observations (Sun perpendicular to the plane of the experiment) (Michelson \& Morley 1987). Therefore, there is no "wind" causing the required change in the diffraction pattern, but a tidal force of $\vec{\nabla} \rho$ is present.

Note that the theory used by Michelson-Morley is inconsistent with the Fizeau experiment.

The STOE model suggests the carry-along concept will produce a zero result. But the result was not zero and was in a different direction than a possible "wind". Perhaps Fitzgerald was correct in suggesting a real contraction of matter. The STOE suggests a contraction based on the $\rho$ value in the immediate 


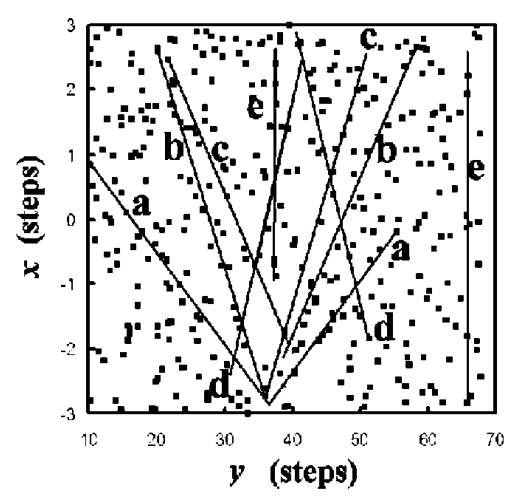

Figure 4: Coherent distribution of photons from Hodge (2012).

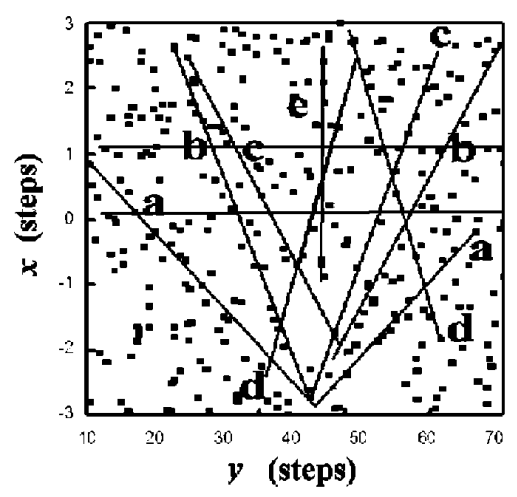

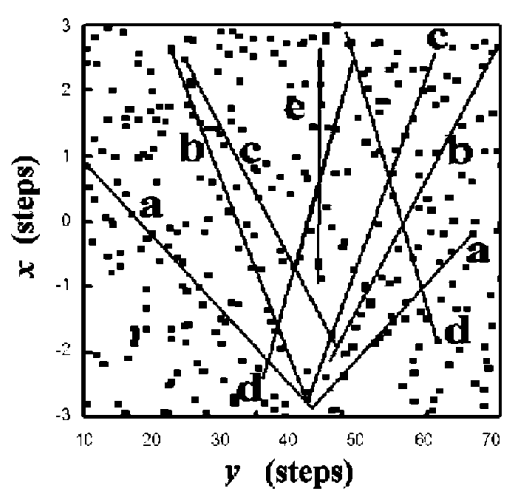

Figure 5: Distribution of coherent photons if source moving away.

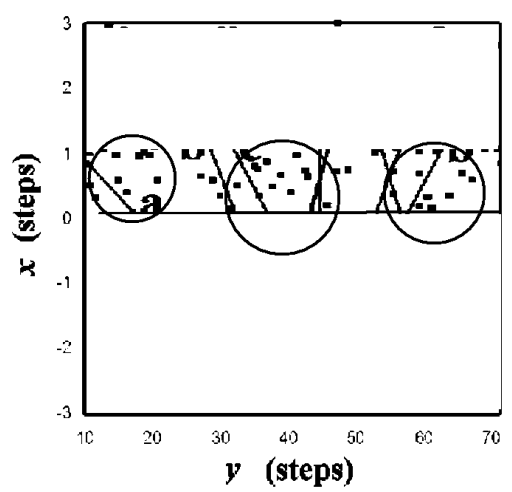

Figure 6: Distribution of coherent Figure 7: Distribution of coherent photons if source moving away fo- photons if source moving away focused view. cused view with the concentrated areas circled and after moving through a slit. 
environment of the matter such as across the experimental apparatus. This contraction is speculated to be a variation between atoms or between hods caused by the variation of the overall $\rho$ value.

The STOE speculates that bodies are composed of hods held a distance between hods. This model was simulated by disk magnets such as seen in Fig. 8 for a neutrino (Hodge 2015e). If the distance between hods is reduced such as depicted in Fig. 9, the body is subject to disintegration. This lessens the particles' size but not the gravitational mass. Thus, particles contract toward the center of spiral galaxies and become black holes. The black holes compress to release high-energy photons which radiate outward as observed in periodic Xray bursts without accompanying radiation of other frequencies (Hodge 2006b). A subset of length contraction is aberration because of the direction of photon movement.

The STOE speculation of atomic structure is that electrons are held in place by photons that are columns of hods such as depicted in Fig. 10 (Hodge 2019i). Also, such as compression may be the Heaviside Ellipsoid compression of the coulomb field. Such a structure would also compress with varying $\rho$ that would cause the distance between atoms to change as $\rho$ changes.

\section{Length contraction}

Length contraction is a measurement phenomenon. That is, the length of rods does not change from one inertial frame to another due to the relative velocity. Figure 11 shows the actual length of a rod $l=P_{3}-P_{1}$ in the comoving coordinate system where the P's are points of interest. The length $l^{\prime}=P_{2}-P_{1}$ as measured in another coordinate system $(\mathrm{O})$ moving at a constant velocity $v$. The distance moved during the time $t$ a photon takes to move from $P_{1}$ to $O$ is $v t$ as shown on the diagram. $P_{2}$ was the position of the end $\left(P_{3}\right)$ at $t=0$. During $t$, light travels toward the observer and moves a distance of $c^{\prime} t$. That is, the direction of light appears to originate from each end of the rod. Therefore, the $l^{\prime}<l$ by the Lorentz factor.

The measured length contraction depends on the speed of the communication such as light speed or sound speed. Measuring gravitational mass depends on the speed of a wave in the plenum. The speed of plenum waves is the speed of gravity which is many times the speed of light (van Flandern 1998). For example, Fig. 12 depicts the difference in identifying the center of a moving rod measured by light and by the plenum wave (gravity).

A subset of length contraction is aberration because of the direction of photon movement.

\section{Moving magnet and conductor problem}

Maxwell's Equations suggests fields that transform according to Lorentz invariance. The STOE posits hods are permanent magnets. Electromagnetic 


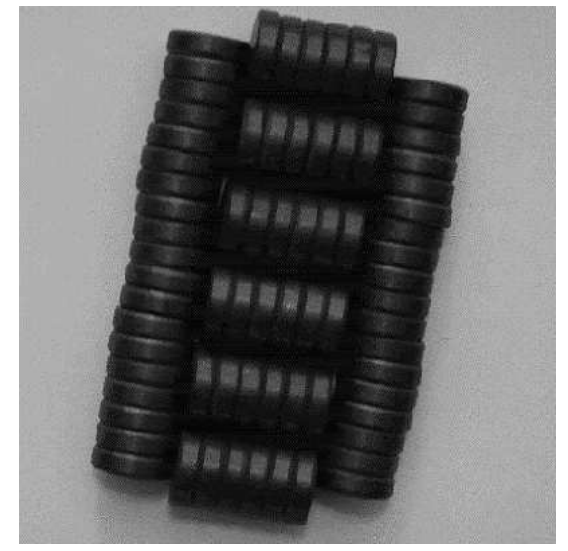

Figure 8: STOE structure of a neutrino in our region of the Milky Way Hodge (2015e).

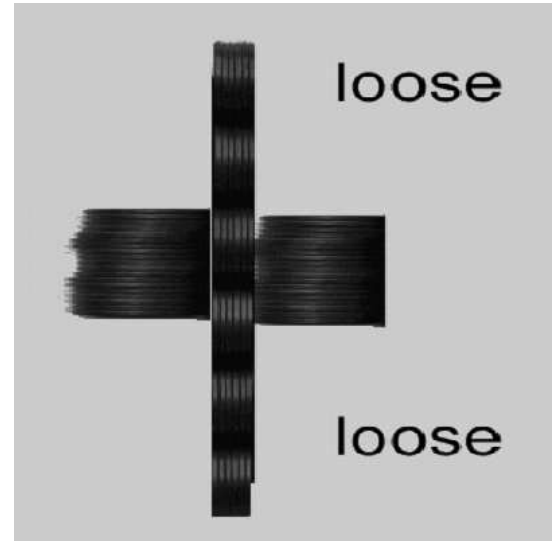

Figure 9: STOE structure of a neutrino in a region of the Milky Way closer to the center.

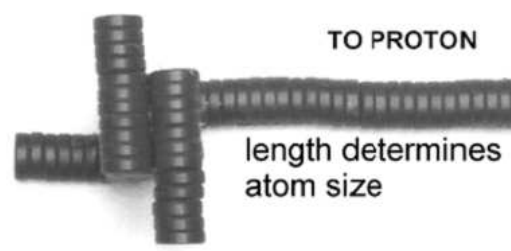

electron

Figure 10: Distribution of coherent photons if source moving away focused view (Hodge 2019i). 


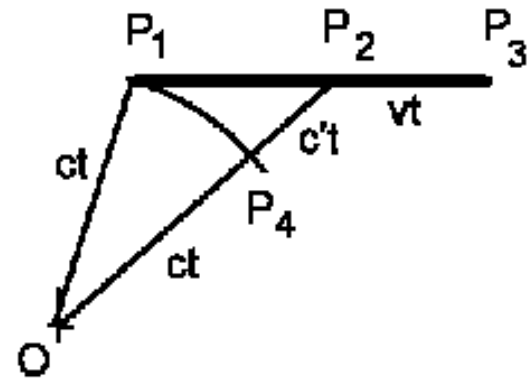

Figure 11: The length of a rod and its measured length.

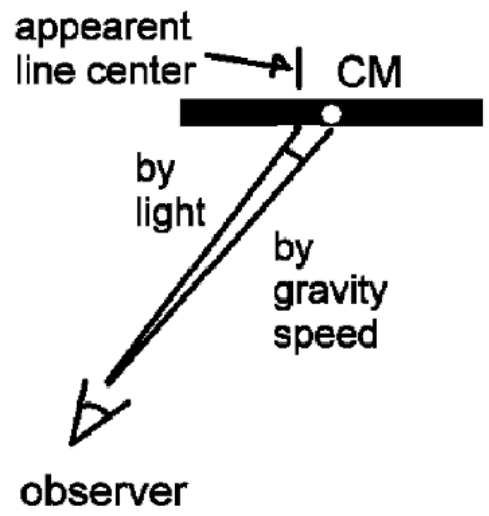

Figure 12: The length of a rod and its center as measured by light and as measured by gravity.

radiation signals are hods that travel at the speed of light. The magnetic field is the plenum density that is high on one side of a hod and zero on the other side (Hodge 2019j). The coulomb force is a plenum effect because it travels at the speed of the plenum (de Sangro 2012).

The moving magnet and conductor problem is a variant of the earlier Faraday paradox associated with Maxwell's Equations. If a magnet is in motion and a conductor is stationary in a lab frame, an electric field arises in the conductor. If the conductor is in motion and the magnet stationary, no electric field around the magnet arises.

The STOE has noted an inconsistency between Faraday's law of induction and Ampere's circuit law that derives from the Biot-Savart law. The experiment of Hodge (2018a,b) demonstrates the magnetic effect of a current in a wire is ejected perpendicular to the wire. That is, the integration along the entire length of the wire in the Biot-Savart law is incorrect. The STOE suggests the hods with their magnetic characteristic are ejected from the wire. Calculations using the Biot-Savart law's cross product or Ampere's circuit law dot product are incorrect.

Another experiment demonstrates the magnetic field induced by a electric current traveling at hod speed is not the same magnetic field from permanent magnets traveling at plenum wave speed (Hodge 2018c). That is, two different types of magnetic field that in Maxwell's Equations are considered as one variable. Therefore, the speed of an electromagnetic wave (speed of light) calculation from Maxwell's equations is incorrect.

Consider an analogy of a wave on a string,

$$
v^{2}=\frac{T}{\sigma}
$$




\section{CLOCKS}

where $v$ is the velocity of the wave, $T$ is the tension on the string, and $\sigma$ is the inertia per unit length that keeps the string moving.

The STOE suggests the hod is a permanent magnet that warps the plenum density. The warp causes gravity. The warp is a tension in the $\rho$ field. The plenum has the property of inertia and the inertia of bodies is the captured plenum in a body (Hodge 2017a). The speed limit of the hod depends on its inducing a tension in the plenum and the $\rho$ environment.

$$
\begin{gathered}
v^{2} \sim c^{2} \\
T \sim \mu^{-1} \\
\sigma \sim \epsilon \\
c^{2}=\frac{\mu^{-1}}{\epsilon},
\end{gathered}
$$

where $c$ is the maximum speed of the hod(s) or electromagnetic speed, $\mu$ is the permeability of the plenum environment, and $\epsilon$ is the permittivity of the plenum environment. The $\mu$ and the $\epsilon$ are the proportionality constants in Maxwell's Equations as re-interpreted by the STOE.

\section{Clocks}

Clocks are assumed (designed) to produce a uniform duration between ticks (events). They consist of two parts, the physical process that is repeating and the counting mechanism. Therefore, the "clock" is really just comparing one physical process with another. The "time" abstract concept is a misinterpretation in physics.

Consider a pendulum clock. The pendulum clock is well modeled. We can predict the tick rate if the clock is placed in a box and dropped. The time between ticks slows if not stops. Similarly, the tick rate slows or stops if placed in an accelerating plane, at a higher altitude, etc.

We have no model of the decay rates of atomic clocks beyond the statistical description. But, the statistical description omits the mechanism of decay. Without the knowledge of the mechanism of decay, ascribing the rate of time progression to time dilation is questionable (Rautio 2020). For example, the muon decay rate while falling may be analogous to a free falling pendulum clock in a box. The change in decay rate may indicate the cause of decay.

\section{Time dilation}

The concepts of "space" and "time" are only backdrops in the STOE where events play out their trajectories. "Space" allows movement to and back and is distance between objects. "Time" is only in one direction, the "arrow of time" and is the duration between events. Processes are NOT symmetric as current physics suggests measured by "entrophy". 


\section{DISCUSSION AND CONCLUSION}

Another phenomenon attributed to time dilation is two different photons traveling through the plenum with different $\rho$. For example, the Shapiro delay of the photons traveling closer to the Sun is traveling through a lower $\rho$ than the photon traveling farther from the Sun. The STOE suggest the time difference is because the slower speed of the photons traveling closer to the Sun. Therefore, the delay is the slower speed not time dilation. Another phenomenon is the bending of light around massive objects. The inner photons travel slower. This is consistent with the Hodge diffraction experiment (Hodge 2015c).

\section{Discussion and Conclusion}

The list of problematical observations that the STOE explains continues to grow with an improved understanding of the universe (Hodge 2015d, 2016, 2020).

The scalar $\rho$ depends on all the masses, Sources and Sinks in the universe. The $\vec{\nabla} \rho$ gives the "gravity" and Mach's Principle. The STOE Relativity considers the accelerated frame indistinguishable from the inertial frame. This has already been used to calculate the galaxy redshift and the Pioneer Anomaly. This gives the Poisson Equation. The STOE extends into General Relativity scales by considering the changes in position of the masses, Sources, and Sinks which will yield the d'Alembert's Equation without the complexity of tensor General Relativity that involves the conversion to geometry and the inverse conversion to gain physical observations.

The STOE calculates all physical quantities as invariant under velocity except as specifically calculated or as caused by changes in $\rho$. Therefore, the laws of nature are scale invariant. Therefore, the relation of gravity and scale invariance becomes clear.

The STOE rejects the notion of spacetime because of the arrow-of-time. The STOE arrives at the Equivalence Principle by a particle structure argument (Hodge 2015e). Therefore, geometric gravity and spacetime are unnecessary.

Each of the STOE axioms has been used in the development of models of observations in the big and the small. The strength of the Scalar Theory Of Everything (STOE) is its ability to describe an extremely wide range of observations and to predict observations. The axioms that replace Special Relativity are: (1) Time is an abstraction of the duration between events causing events. (2) The diameter of the hods is the same throughout the universe. (3) The distance between hods in a particle is related to plenum density $\rho$. Higher $\rho$ reduces the distance between hods. (4) The speed of photons and hods (light) is the greatest of any matter in a given environment. And (5) The speed of the plenum wave is much faster than the speed of the hods. The STOE passes the tests of Special Relativity and does much more. The STOE is a major paradigm shift.

ORCID iD

John C. Hodge: https://orcid.org/0000-0002-1520-2153 


\section{REFERENCES}

\section{References}

Afshar, S.S., 2007, Violation of the Principle of complementarity, and its implications, Proc. SPIE 5866, p. 229 http://www.arxiv:quant-ph/0701027 DOI 10.1117/12.638774

de Sangro, et al., 2012, Measuring Propagation Speed of Coulomb Fields, https://arxiv.org/abs/1211.2913 .

Hodge, J.C., 2004, Changing universe model with applications, http://www.arxiv.org/abs/astro-ph/0409765v1

Hodge, J.C., 2006a, Scalar potential model of redshift and discrete redshift, New Astronomy, Volume 11, Issue 5, March 2006, Pages 344358. http://www.sciencedirect.com/science/article/pii/S1384107605001387. http://www.arxiv.org/abs/astro-ph/0602344v1

Hodge, J.C., 2006b, Scalar potential model of the CMB radiation temperature, https://www.arxiv.org/abs/astro-ph/0603140

Hodge, J.C., 2006c, Scalar potential model of the Pioneer Anomaly, http://www.arxiv.org/abs/astro-ph/0612567v2

Hodge, J.C., 2012, Photon diffraction and interference, IntellectualArchive, Vol.1, No. 3, P. 15, http://intellectualarchive.com/?link=item\&id=597

Hodge, J.C., 2015a, Single Photon diffraction and interference, http://intellectualarchive.com/?link=item\&id=1557

Hodge, J.C., 2015b, Light diffraction experiments that confirm the STOE model and reject all other models, http://intellectualarchive.com/?link=item\&id $=1578$

Hodge, J.C., 2015c, Diffraction experiment and its STOE photon toy simulation program rejects wave models of light, http://intellectualarchive.com/?link=item\&id=1603 see video "stoe photon diffraction". (https://www.youtube.com/channel/UCc0mfCssV32dDhDgwqLJjpw)

Hodge, J.C., 2015d, Universe according to the STOE, http://intellectualarchive.com/?link=item\&id $=1648$

Hodge, J.C., 2015e, Structure and spin of the neutrino, electron, and positron, IntellectualArchive, Vol.5, No. 2, P.1-8 , http://intellectualarchive.com/?link=item\&id $=1648$

Hodge, J.C., 2016, STOE assumptions that model particle diffraction and that replaces $Q M$, http://intellectualarchive.com/?link=item\&id=1719

Hodge, J. C., 2017a. STOE inertia, IntellectualArchive, v.6(1), P. 158,http://intellectualarchive.com/?link=item\&id=1814. 


\section{REFERENCES}

Hodge, J.C., 2017b, Hodge experiment (continued) of interference with a slit in a transparent mask rejects wave models of light, IntellectualArchive, Vol.6, No. 6, p.1-6 http://intellectualarchive.com/?link=item\&id=1862 video: https://www.youtube.com/watch?v=A07bogzzMEI

Hodge, J.C., 2017c, Hodge experiment (continued) with opaque strips and about the Afshar Experiment, IntellectualArchive, Vol.6, No. 5, p.7-18 http://intellectualarchive.com/?link $=$ item\&id $=1872$

Hodge, J.C., 2018a, Magnetostatics relation to gravity with experiment that rejects Biot-Savart Law, IntellectualArchive, Vol.7, No. 3, p.1-8 http://intellectualarchive.com/?link=item\&id=1945 See video: https://www.youtube.com/watch?v=A07bogzzMEI

Hodge, J.C., 2018b, Another experiment rejects Ampere's Law and supports the STOE model, IntellectualArchive, Vol.7, No. 4, p.1-5 http://intellectualarchive.com/?link $=$ item\&id $=1956$

Hodge, J.C., 2018c, Two different types of magnetic field, IntellectualArchive, Vol.7, No. 4, p.1-8 http://intellectualarchive.com/?link=item\&id=1964

Hodge, J.C. 2019a. Interference Experiment with a transparent Mask Rejects Wave Models of Light, Optics and Photonics Journal, v.9(6). DOI: 104236/opj.2019.96008. http://www.scrip.org/journal/paperinformation.aspx?paperid=93056. See video: https://www.youtube.com/watch? $=$ =A07bogzzMEI

Hodge, J. C. 2019b. STOE explaination for the "ether wind". IntellectualArchive, v.8(2), P. 15. http://intellectualarchive.com/?link $=$ item\&id $=2111$.

Hodge, J.C. 2019i. Magnetic field evolves to gravity field:4 Atomic structure. IntellectualArchive, v.8(4), $\quad$ P. 30. http://intellectualarchive.com/?link=item\&id=2199.

Hodge, J. C. 2019j. Magnetic field evolves to gravity field:5 Final. IntellectualArchive, v. 8(4), $\quad$ P. 37. http://intellectualarchive.com/?link=item\&id=2233.

Hodge, J.C., 2020, Scalar Theory of Everything (STOE) unites the big, the small, and the four forces (GUT) by extending Newton's model, IntellectualArchive, Vol.9, No. 4, p. 14 http://intellectualarchive.com/?link=item\&id $=2414$

DOI: 10.32370/IA_2020_12_3

Michelson, A.A. \& Morley, E.W., 1987, On the Relative Motion of the Earth and the Luminiforus Ether, American Journal of Science, 34 (203) p. 333-345. 


\section{REFERENCES}

Rautio, J.A., 2020, Variability of decay rates points to a new theory of particles and gravity, https://www.researchgate.net/publication/350314443 and references therein. See also papers by Ephraim Fishbach and his team.

von Flandern, T., 1998. Physics Letters A 250, 1.

Verdad, F., 2019, Diffraction and the speed of light, DOI: $10.13140 /$ RG.2.2.25062.98888 


\title{
Physics use of mathematics
}

\author{
J.C. Hodge ${ }^{1 *}$ \\ ${ }^{1}$ Retired, 477 Mincey Rd., Franklin, NC, 28734
}

\begin{abstract}
Orthodox physics makes extensive use of number relation mathematics such as mapping, probability, and infinite series. This mathematics is devoid of causative relations. Other scientific disciplines such as medicine and chemistry use causative models. Using causative models would advance physics. Causation should be overtly stated in the mathematics. Causation is linked with emergence philosophy and not reductionism.
\end{abstract}

\section{Introduction}

Humans have limited ability to comprehend the universe. Our knowledge is neatly divided into separate and independent disciplines. Our survival depends on a generalist approach that adheres to the laws of the universe. Our experience in the macroscopic world serves as a base for expanding our knowledge. Our environment is continually changing. Maintaining status quo is not an option.

Understanding is the ability to predict events and observations. Wisdom is the ability to cause events and observations (Hodge 2012). Humanity has discovered that greater Understanding and greater Wisdom yields survival and population growth.

Humanity lacks the Wisdom to create a universe. But it has the Understanding to predict some events. The Wisdom humanity has is a smaller subset of Understanding that is a small subset of ontology. Thinking any of humanity's Understanding reflects ontology of the universe is hubris.

\footnotetext{
${ }^{*}$ E-mail: jchodge@frontier.com
} 


\section{INTRODUCTION}

Human Understanding devoted to expanding our survivability can be divided into two general categories: religious and scientific. Each has developed methods and criteria to advance human Understanding. Each works by recognizing patterns in the universe and by passing tests of survival.

Human modeling starts from postulates, which include methods of reasoning (logic), and extends to theorems. Theorems must be useful in predicting events. Survival for a longer time requires the amount of useful information and models to be expanded. Humans have developed models of how the universe works to serve the required expansion. "More fundamental" means the models humans need to explain the complexity of the entire universe (most general) could be simpler and more useful at the expense of an increased need for synthesis. This is Occam's razor applied to the human understanding of the universe. The synthesis of emergent models replaces the analysis of reductionism. The rules for synthesis must also be more universal.

Religious Understanding predominantly concerns human social and human organizing. The time span of test and improvement is centuries. The universe (nature) tends to work by rejecting competing systems (Carroll 2016) as does physics. Because of the time required to determine rejection, the religious method of logic is "trial-and-error". Typical moral thinking seems to lack mathematics, but statistics can model the characteristics of human development and suggest human organization theories. However, these theories are not yet at the Wisdom state of Understanding. The observation of several existing moral systems suggests humanity has much to learn.

Scientific Wisdom is concerned with the physical effects in the universe. Mathematics can "prove" the theorems by being self-consistent with its own postulates. Being "useful" is not a criterion for mathematics. Physical sciences must be consistent with observations that are the result of the largely unknown ontological workings of the universe. Therefore, physics can only reject arguments from the postulates. If the logic and the measurements are valid, then adjusting the postulates attains an increase in Wisdom.

A necessary paradigm shift in the fundamental models is long overdue.

This paper considers current knowledge concepts. Religious concepts are part of life and society. The next Theory of Everything model is considered to be a unification of principles for cosmology and Quantum Physics (QP). The Scalar Theory of Everything model (STOE) suggests the same set of principles should include life and society observations. The STOE demonstrates the type of postulate changes required. The basic functioning of the Universe is discussed in Section 2, Section 3 discusses causality and determin- 
ism, infinite mathematical series is discusses in Section 4, valid and invalid Mathematical Characteristics are discussed in Section 5, and emergence is discussed Section 6. The conclusion is in Section 7 .

\section{Basic functioning of the Universe}

Our daily experiences in our world suggests:

"Matter" coalesces into larger, cohesive bodies that may be considered as acting as one. Particles become atoms, molecules, bodies, life, and society. This is the emergence of increasing complexity.

\section{Relations between bodies .}

Change and Competition for limited Resources.

Fractal structures are common throughout the universe.

\section{Causality .}

Feedback loops cause a fine-tuning of parameters. The feedback loop between Sources and Sinks (Hodge 2006a) cause the hunting of the average temperature of the universe. This suggests that the universe is a series of nested feedback loops. The problem is identifying them. An atheist dilemma is from whence the feedback loops. Perhaps these are the many worlds within our universe.

\section{Causality and Determinism}

Causality is a prime topic and goal in many areas of human modeling (Beebee et al. 2009; Pearl 2010). Philosophers in epistemology investigate how causation may be inferred from statistical and observational data.

Causation is a contested concept in physics. Perhaps this is because a causal assumption is behind every causal conclusion. That is, causality is not an observation. The slogan "correlation does not imply causation" is particularly poignant in physics. However, models invoking causality rely on some premises that are not measured, but can result in predictions with changing conditions. 


\section{CAUSALITY AND DETERMINISM}

Statistical analysis assesses the parameters of a distribution drawn from a sample. Associations among the parameters are then inferred. This task is well managed to the purposes of physics as long as the experimental conditions remain the same. Indeed, the Universe is one, therefore one can expect all events are related to some degree of correlation to all other events.

The aim of physics must be to predict events under a dynamics of changing and unmeasurable conditions. The application of statistical methods is only a first step in observation that lack causality. Unfortunately, this is the condition in both cosmology and QP. However, "causality" is not a measurable observation. Therefore, causality is a necessary part of models, only. Further, models that omit causality are incomplete models.

A useful distinction between number concepts and causal concepts is as follows. A number, only, concept is any relationship that can be defined in terms of joint distribution of observable values. A causal concept is a relationship that cannot be defined from distributions alone and that has a before and after ingredient. The causal concept can be applied to observations that are outside the realm of the conditions of number models. Therefore, QP causation should be able to apply to cosmology.

Certain concepts have aided humanity develop greater Wisdom. The determinism of events and observations should be assumed even if the ontology of the universe is not deterministic. Therefore, cause-and-effect is assumed for all observations where effects are not assumed. Models are the suggestions of patterns of cause-and-effect. Yet, all models must have some assumed effects without causes. All other observations are then to be derived by the model. Because of human limitations, the better model has a minimum of uncaused effects while deriving all observations. For example, part of the unifying of cosmology observations and observation of the small should be the unifying of the uncaused effects. The STOE plenum is like the "space" of GR and the medium supporting wave action of QP. These are not anthropic type principles. Without determinism and cause-and-effect humanity would be unable to increase Wisdom.

However, even if the universe were ontologically deterministic, the assumptions made about the initial conditions would have to allow some undetermined cause. Therefore, the universe is ultimately unpredictable. So, the best that humanity could do is predict within a limited amount of duration and a limited amount of distance. Humanities quest for Wisdom is to expand these limits.

The use of statistical mathematics may be used when Understanding of 


\section{CAUSALITY AND DETERMINISM}

a physical model is inadequate. When the causes of disease were unknown, statistics help Understand and Predict likely out outbreaks and correlations. The correlation with polluted water helped reduce cholera although a physical cause was unknown.

QP uses a statistical approach. Some interpretations of QP suggest a physical reality. However, some of these interpretations result in many weird propositions. The STOE suggests that the universe is self-similar. Therefore, the equations and physical reality of the Newtonian scale apply to the very small scale. The core of QP rests on the explanations of light. The interference experiments seem contradictory to particle experiments such as the photoelectric experiment. The STOE follows the Newtonian model of light (Newton 1730, queries 17, 18, 19, 20, and 21). The Bohm Interpretation suggests particles have a definite position and momentum and the statistics results from an imprecise measurement. The Transactional Interpretation (TIQP) posits a wave returning from the future. The STOE suggest the "future" wave is a real wave that travels much faster than light in a real medium and that reflects from objects ahead of the photon. This medium wave is Bohm's "hidden variable". Thus, quantum eraser and entanglement experiments can be explained.

The model of a photon as a structure (Hodge 2016a) also suggests the light emitted from atoms suggests the atomic structure is rigid photons not electrons in orbits(Hodge 2019b). This model avoids many conceptual problems such as the lack of the decay of orbits without emission and the many ad hoc "selection rules".

Accepted physics has been reluctant to embrace causality among "spacelike" events. This has resulted in separate and political coexistence between Relativity (GR) and Quantum Mechanics (QP). However, the recent endeavor to find a "graviton" is suggesting recognition to merge these models. Also, the "entanglement" experiments require a Bohm-type "hidden variable" (violating "local-causality"). That is, requiring models to be causal may result in better predicting and useful models.

That an equation is causative requires a replacement of the equals sign $(=)$ such as $\rightarrow$. So, $\vec{\nabla} \rho \rightarrow \vec{F}$ implies $\vec{\nabla} \rho$ causes the $\vec{F}$. Whereas, $\vec{\nabla} \rho=\vec{F}$ implies only the values are the same.

Consider, the field equation in General Relativity. The right hand side (RHS) of energy and momentum are calculated values with an equal sign. The left hand side (LHS) are, at best mapped/fictitious values of $s$ and $t$. These values have no suggested relation to QP. Now redo the basic concept 


\section{INFINITE SERIES}

with causation. The RHS is of values, only. The reality to measured parameters is mass, distance, and time. That is, forces applied over distance and duration rather than energy which ignores dissipative forces. These cause the $s$ and $t$ parameters which now must be real and describe a varying geometry. But this interpretation may also apply to Bohm's model of his "hidden variables". Thus, insistence on causation provides a link between GR and QP. All we have to do is loose Special Relativity.

\section{Infinite series}

Describing data relationships with infinite series such as the Fourier Series and the Power Series works with any data relations. Such descriptions may have many, even unlimited, constants. Ptolemaic description of the planets orbits involves a simple Fourier Series - circles within circles. The numbers matched the data with good precision and forecast ability. The later Copernican model with elliptic orbits and Newton's gravity replaced it with a causative model.

The early description of the Rotation Curves (RCs) by Vera Rubin used a Power Series to model the data. The later Dark Matter model and later still the Quasi Steady State Cosmology and STOE model placed a Source at the center of spiral galaxies as a cause of the observed RCs.

Currently, QP wave analysis is a Fourier Series approach. The STOE is suggesting a causative model to replace QP.

\section{Valid and invalid Mathematical Character- istics}

Humanity has created mathematical methods of the universe that aid Understanding and Wisdom. If mathematics is a core characteristic of our universe, the success of mathematics helping humanity suggests that a high degree of rationalism is fundamental. Mathematics rejects the idea of duality.

Mathematics has two varieties, algebraic and geometric. Algebra deals with numbers that are counts of discrete things. Physics adds the standard of measure as the thing counted. Special functions of mathematics may be abstract so that the count is unrelated to measures and, therefore, unrelated 


\section{VALID AND INVALID MATHEMATICAL CHARACTERISTICS}

to physical processes in the universe. Geometric mathematics deals with continuous shapes.

When describing physical events or entities in the universe, the computation must yield some other observed value or shape in the universe, which may be in the future. Physics models create algorithms. That is, algorithms are cause-effect models of universe processes. An algorithm that yields an unobserved outcome or fails to yield an outcome (addressed by Turing as "uncomputable" and by Gödel as undecidable) is non-physical. The universe does produce outcomes over time. If a model suggests the outcome should be observed and it's not, then the algorithm is incorrect for the model or the model is incorrect. That is, an algorithm representing the physics of a universe process must be computable and decidable.

But mathematics and physics currently have limited ability to describe and predict events. Concepts outside those limits are considered with vague and poorly defined concepts. Consciousness, aims, and intentions are such concepts. Without a scientific definition, the discussion must be vague, subject to many interpretations, and, therefore, useless. Perhaps a new math may describe consciousness and brain functioning.

The STOE suggests a Universal Equation that calculates the force exerted at every point is a function of all galaxies and all mass in the universe (Hodge 2018b, 2020). The STOE is causal and Machian. However, the long-term average temperature of galaxy clusters hunts the same value for all clusters. Therefore, perhaps only a galaxy cluster need be considered (Hodge 2006b). The STOE concept serves to calculate the asymmetry of rotation curves (Hodge 2006c) and the periodic redshift measurements (Hodge 2006a) that mystify other models.

Human physics computability is limited by the degree of accuracy of a measurement. However, the universe has no such limitation. Another limitation results from having incorrect assumptions about the functioning of the universe and about the initial conditions of a modeled process. Mathematics starts with human assumptions, not physical assumptions.

The accepted units of standard measure lack some parameters such as the "cycle". Also, commonly used is that $c=G=h=1$ with no units. That these may vary is then lost in the mathematics.

The operation of division is used in mathematics but is disallowed in the universe. For example, a line is the extension of a point in space. A line defined as an infinite number of points is not physical. That is, irrational numbers such as $1 / 3$ and a result of infinity such as division by zero are 


\section{VALID AND INVALID MATHEMATICAL CHARACTERISTICS}

not points of a line. The key is that division introduces an uncertainty in a human calculation similar to a measurement uncertainty.

Transformation equations introduce fictitious parameters to aid the calculation. They are subject to all the potential problems of mathematics such as division by zero. The General Relativity (GR) field equation is such an equation. The introduced parameters are unreal. They must be re-converted to measurable parameters.

The STOE suggests the physical universe uses only cardinal numbers with zero and excludes negative numbers for physical values. For example, the particle and antiparticle behavior is due to differing structures (Hodge 2016a). The structure determines the type of vortices they cause. These vortices annihilate upon joining ( + and - ) (Hodge 2018a). This model has the additional advantage that the less probable structures are less numerous in the universe.

The ordering of universe physical conditions (ordinal numbers) derives from the measurements. That is, a single step $(+1)$ of the ordinal number may have varying measurement values and is non-physical. Therefore, the range of natural numbers is non-physical and confined to mathematics.

The STOE suggests one of the most fundamental components of the universe is physically continuous (Hodge 2014b). Natural numbers may represent the continuous component such as $\pi$ and such as transcendental functions only to an uncertainty level. The waves in the continuous component and the Universal Equation maintain the geometric lengths of distance without the division required by the algebraic calculation.

Other mathematical concepts of imaginary numbers, more than three spatial dimensions, and transforms should be viewed with skepticism. If a model calculation yields an unobserved value, then suspect the mathematics model process in addition to suspecting the assumptions. But, these mathematical concepts are mere band-aids to cover a need for a better physical model of initial conditions and processes. The STOE is an example of how this may be done.

Until humanity can create a universe, the inaccuracies of human physical models continue.

The synthesis of mathematics with physical observation has resulted in greater and more accurate predictability. The end goal is survival through usefulness. 


\section{EMERGENCE}

\section{Emergence}

Emergent agents and their simple rules of behavior form more complex entities and behaviors (Hodge 2016c). Two is a very fundamental form of organization. The STOE suggests there are two fundamental, physical components (hods and plenum) with their Spirit (interaction) and two major structures (sources/spiral galaxies and sinks/elliptical galaxies) of the universe (Hodge 2014b). The STOE Universal Equation is not a mathematical transformation because both sides of the equation are posited to be real physical entities. The hod/plenum model is the only model to predict and describe the Hodge diffraction experiments that rejects all wave model of light (Hodge 2014c, 2019c).

The relation between the agents and the emerged entities is causal. Therefore, because a single universe exists, a single Theory of Everything exists involving causal and Machian relations from the very small to the very large and involving the cause of society's success and life' consciousness (Hodge 2020). Additional concepts such as fractal structures and negative feedback loops from the emergent principal that describe the universe are also helpful.

The dark matter hypothesis is not an emergent, causal component of the universe. It is not a more primitive form because it doesn't emerge into baryonic matter. Instead it adds complexity rather than being simpler.

For example, life's principle of the survival-of-the-fittest could be applied to particles where only the structures of the long-lived particles (photon, electron neutrino, and electron) are key. The Serengeti rules (Carroll 2016) suggest feedback rules reject the weak rather than support the stronger. Likewise the CMB's feedback forms the temperature of the universe (Hodge 2006b). So, the stable agents at a given level of emergence are allowed to form diverse structures with their spirit. The unstable are rejected. The remainders are merely temporary as they form into more stable structures.

Combinations of simpler structures form more complex life. Human embryos go through the stages of evolution. State societies are composed of families, tribes, and chiefdoms. Likewise, electrons and neutrons are composed of photons. The analogy of one fractal scale to another is the ancient Chinese "Proof by Analogy".

Life has found the division of labor/energy/force into two sexes provides survival for more complex life forms. Darwin is credited with making a great stride in Understanding about life without an understanding in mathematics (Livio 2013). But Darwin had problems in how traits are passed to the 


\section{CONCLUSION}

next generation. Perhaps because of the lack of mathematics, it remained for Mendel to introduce genetics models into life process models. Gregor Mendel may have been thinking of sex division by two when he designed his experiments to look for two (dominant v. recessive) traits (Bronowski 1973). The sex of a child is not averaged. Cells divide by two. There are two strands of DNA. How the life functions are divided varies among species. The division of nurturing and provide/protect seems to allow humans a more complex structure (Hodge 2012). Boolean mathematics has allowed the construction of computers where base-three arithmetic failed. Societies must still survive natural internal collapse tendencies (Glubb 1977; Tainter 1990).

The life and society structures are thermodynamically open systems. Consequently, the universe is not adiabatic and is an open system with Sources and Sinks (Hodge 2014b).

Conversely, if a principle appears simpler for the data in physics but fails in life and society observations, then the principle is false. The fundamental principle is Nature's rules must be obeyed.

\section{Conclusion}

Humanity currently requires a paradigm shift in models of physics, life, and society. The amount of unexplained observational data is huge. More fundamental, causal, Machian descriptions are simpler, more useful, and apply to the entire universe including areas of mathematics, physical sciences, life, and society. Unphysical mathematical concepts are mere band-aids to cover a need for a better physical model of initial conditions and processes. The STOE is an example of how this may be done. However, because the universe's source of initial conditions is unknowable, the universe is unpredictable except for limited distance and duration.

Using causative models would advance physics. Causation should be overtly stated in the mathematics. Causation is linked with emergence philosophy and not reductionism.

\section{References}

(Eds.) Beebee, H., Hitchcock, C., and Menzies, P., 2009, The Oxford Handbook of Causation, (Oxford University Press, New York, New York, U.S.A.) 


\section{REFERENCES}

Bronowski, J., 1973, The assent of man, (BBC DVD, Ambrose Video Publishing, Inc., New York, New York, U.S.A.)

Carroll, S. B., 2016 The Serengeti Rules the quest to discover how life works and why it matters, (Princeton University Press, Princeton, New Jersey, U. S. A.)

Diamond, J., 1997 Guns, Germs, and Steel, (Norton, New York, New York, U. S. A.)

Diamond, J., 2012 The World Until Yesterday, (Viking, New York, New York, U. S. A.)

Glubb, J., 1973, The fate of empires and search for survival, (William Blackwood \& Sons, Edinburgh, Scotland). http://www.rexresearch.com/glubb/glubb-empire.pdf

Hodge, J.C., 2006a, Scalar potential model of redshift and discrete, New Astronomy, Volume 11, Issue 5, March 2006, Pages 344-358, arXiv: astro$\mathrm{ph} / 0602344 \mathrm{v} 1$.

Hodge, J.C., 2006b, Scalar potential model of the CMB radiation temperature, arXiv: astro-ph/0603140v1.

Hodge, J.C., 2006c, Scalar potential model of spiral galaxy rotation curves and rotation curve asymmetry, arXiv: astro-ph/0611029v2.

Hodge, J.C., 2012, Survival is the only moral goal of life, http://intellectualarchive.com/?link=item\&id=694 .

Hodge, J.C., 2013, Growth challenge of the United States, http://intellectualarchive.com/?link=item\&id=1093 .

Hodge, J.C., 2014a, Scalar Theory of Everything for steering humanity's growth, http://intellectualarchive.com/?link=item\&id=1310 .

Hodge, J.C., 2014b, Universe according to the STOE, IntellectualArchive, Vol.4, No. 6, P.6 , ISSN 1929-4700, Toronto, Jan., http://intellectualarchive.com/?link=item\&id=1648 . 


\section{REFERENCES}

Hodge, J.C., 2014c, Diffraction experiment and its STOE photon simulation program rejects wave models of light, IntellectualArchive, Vol.4, No. 6, P.11 , ISSN 1929-4700, Toronto, Jan., http://intellectualarchive.com/?link=item\&id=1603 .

RG project:

https://www.researchgate.net/project/STOE-photon-diffraction-and-

interference

Videos:

https://www.youtube.com/watch?v=OMAjKk6k6-k

https://www.youtube.com/watch?v=qFDB-K_sSjU

Hodge, J.C., 2016a, Structure and spin of the neutrino, electron, and positron, IntellectualArchive, Vol.5, No. 2, http://intellectualarchive.com/?link=item\&id=1694 .

Hodge, J.C., 2016b, STOE assumptions that model particle diffraction and that replaces QP, IntellectualArchive, Vol.5, No. 3, http://intellectualarchive.com/?link=item\&id=1719 .

Hodge, J.C., 2016c, STOE emergence, IntellectualArchive, Vol.5, No. 3, 2014, http://intellectualarchive.com/?link=item\&id=1757 .

Hodge, J.C., 2018a, STOE electric charge, IntellectualArchive, Vol.7, No. 2, http://intellectualarchive.com/?link=item\&id=1917 .

Hodge, J.C., 2018b, STOE replaces relativity and quantum mechanics, IntellectualArchive, Vol.7, No. 5, 2018, http://intellectualarchive.com/?link=item\&id=1979 .

Hodge, J.C., 2019a, QSSC model's next step is the STOE, IntellectualArchive, Vol.8, No. 1, http://intellectualarchive.com/?link=item\&id=2043 .

Hodge, J.C., 2019b, Magnetic field evolves to gravity field part:4 Atomic structure, IntellectualArchive, Vol.8, No. 4, 2019, http://intellectualarchive.com/?link=item\&id=2199 .

Hodge, J.C., 2019c, Interference Experiment with a Transparent Mask Rejects Wave Models of Light, OPJ, Vol. 9, No. 6, https://www.scirp.org/journal/paperinformation.aspx?paperid=93056 


\section{REFERENCES}

Hodge, J.C., 2020, Scalar Theory of Everything (STOE) unites the big, the small, and the four forces (GUT) by extending Newton's model, IntellectualArchive, Vol.9, No. 14, 2020, http://intellectualarchive.com/?link=item\&id=2414 .

Livio, M., 2013 Brilliant Blunders, (Simon \& Schuster, Inc., New York, New York, U. S. A.)

Newton, I., 1730 ed. Opticks, (Dover Publications, Inc., New York, New York, U. S. A.). Different edition have a different numbering scheme.

Pearl, J., 2010 The Mathematics of Causal Relations, in Shrout, P.E., Keyes, K., and Ornstein, K. (Eds.) Causality and Psychopathology: Finding the Determinants of Disorders and their Cures (Oxford University Press, Oxford, UK).

Tainter, J. A., 1990. The Collapse of Complex Societies, (Cambridge University Press, New York, New York, U. S. A.) 


\title{
Numerical Studies of Deformations and Crack Propagation in Reinforced Concrete Annular Sections Under Thermopower Loads
}

\author{
I.I. Karkhut Ph.D*, \\ Assistant professor $N U$ «LP» \\ J.J. Luchko Dr.Sc**, \\ Professor LNAU \\ V.V. Kirichok M.Sc ${ }^{* * * *}$ \\ Leading Engineer, Lira group of companies
}

\begin{abstract}
The article describes the current state and the level of research of annular cross-sections of structures of energy facilities operating under conditions of thermal and force effects. The results of a numerical experiment to study the deformability and crack resistance of annular cross-sections and their comparison with the results of testing physical models of fragments of reinforced concrete chimneys are presented. It is shown that at the modern level of development of the mathematical apparatus and computer calculation programs, using the deformation model, the deviation does not exceed $20 \%$. The described research results of other authors and this work confirm the possibility of replacing cost and long-term field tests with numerical experiments.
\end{abstract}

Key words: reinforced concrete ring, thermal power loads, numerical experiment

Introduction. Modern research of reinforced concrete annular cross-sections of structures Trends in the development of engineering practice show that the problem of monitoring the thermally stressed state of elements of engineering structures with the simultaneous provision of reliable conditions for their operation is becoming urgent. Reliable operation of constructed energy facilities, including those with sources of ionizing radiation, requires reliable modern calculation methods to obtain reliable data on the effect on materials and structures. Replacing cost and lengthy field tests with reliable numerical calculation methods is an urgent need to accelerate the development of this industry.

\footnotetext{
*email address: karkhoot1@ gmail.com, ORCID 0000-0002-9205-5118

** email address: lychco.diit@ gmail.com, ORCID 0000-0002-3675-0503

*** email address: k0965976337@ gmail.com, ORCID 0000-0002-4359-7148
} 


\section{Analysis of scientific and technical sources.}

At energy facilities, a lot of research has been carried out on annular reinforced concrete sections, which are under the influence of temperature and power loads [1-8], including those with external sheet reinforcement.

The authors of work [1] carried out research and developed the design of a sealing shell with double external reinforcement. This design provided the required level of fracture toughness of the structure.

Thus, in [2], the quantitative contribution of the effect of temperature drops on the stress in the reinforced concrete annular section and the outer steel shell of the hydraulic tunnel was analyzed. The stresses in the layers of the annular section were determined. It was concluded that the functioning of such a structure with temperature drops in the coolant can be simulated in a numerical experiment with high accuracy. The approach to mathematical modeling and the results of numerical analysis of physical experiments on annular specimens with double external reinforcement were carried out in [1, 3-5]. It was shown that a numerical experiment made it possible to take into account the temperature deformations of concrete with sufficient accuracy and to reduce the costs of research and design.

In [6], the results of the study of the annular beam of the NPP containment are presented. The importance of taking into account the processes of concrete heating in time for an accurate analysis of stresses in an annular section is indicated.

Such an analysis was also carried out in [7] for annular reinforced concrete cross sections under the influence of temperature loads, in which the main influence at an early age on the stressstrain state under temperature loads is created by shrinkage and hydration of concrete. It is shown that the models applied for the numerical analysis give insignificant deviations from the full-scale experiment.

Theoretical dependencies for calculating stresses in thin annular cross-sections of concrete chimneys and their computer analysis based on linear approximation are given in [8]. The influence of heating of the outer face on the stress in concrete with an annular section is considered. The importance of taking into account temperature effects for the design of reinforcement and the possibility of using numerical analysis is shown.

It is more expedient for numerical analysis to apply a nonlinear approximation taking into account the positions of the deformable model [9] and numerically simulate temperatures 
significantly higher than $50^{\circ} \mathrm{C}$, at which the effect of temperature on concrete should be taken into account.

The authors of [10] carried out numerous studies of the deformability and crack resistance of annular elements of protective reinforced concrete structures under the action of internal pressure and one-sided heating up to $150^{\circ} \mathrm{C}$. The results of experimental studies carried out on rings with bar reinforcement of periodic profile were analyzed by V.A. Kostornichenko and A.P. Krichevsky [10]. It was found that the processes of cracking in annular specimens are caused by the presence of temperature bending moments, which depend on the temperature difference in the section, the type and nature of the reinforcement. Since all the studied annular specimens had the same cross-section and percentage of reinforcement (Fig. 1a), the main influence on the cracking processes was created by the nature of the temperature distribution along the height of the cross-section, the duration of the temperature load and the strength characteristics of concrete.

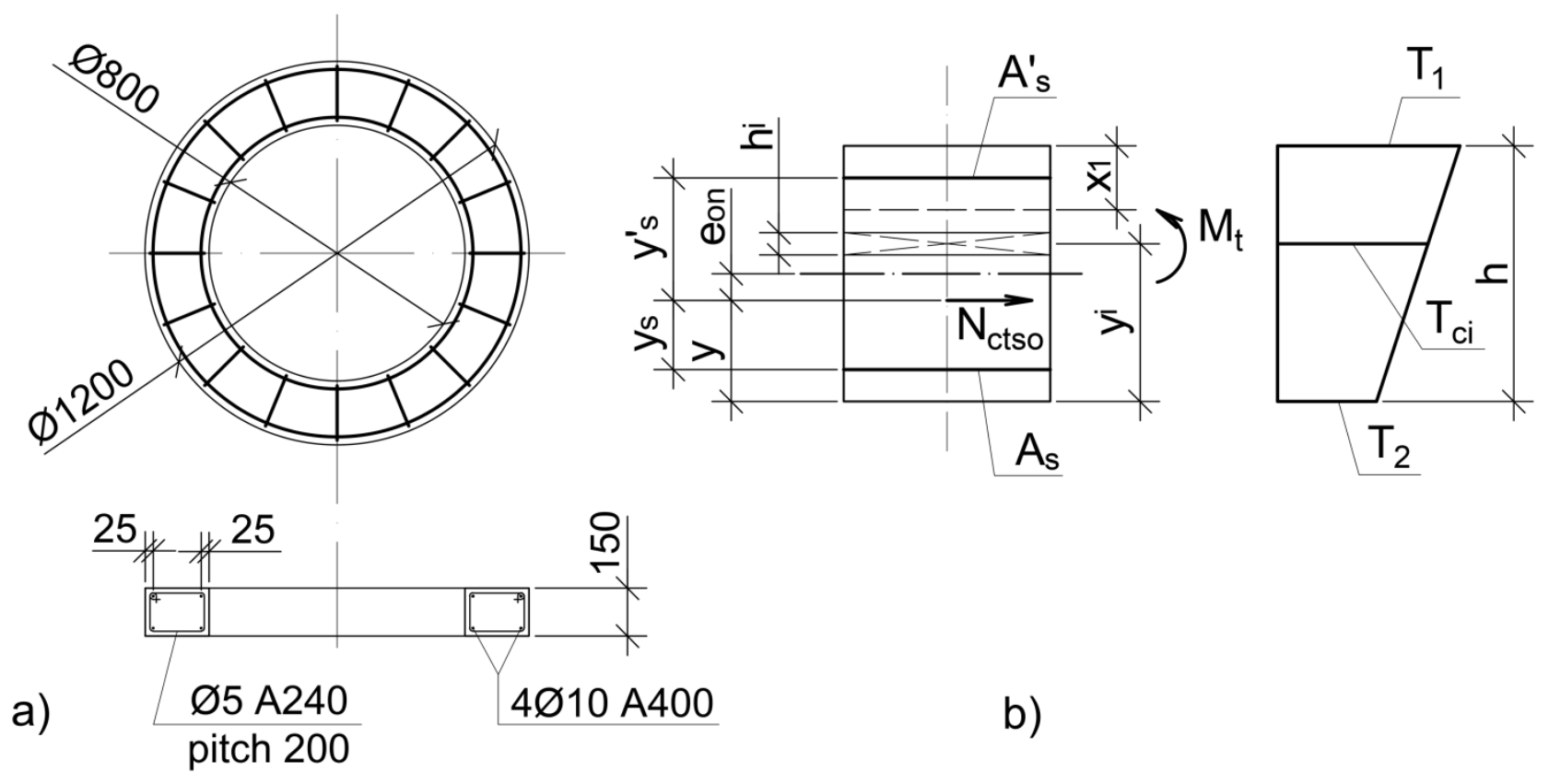

1. The design of the annular sample a) and the design scheme b).

The characteristics of the ring fragments that were investigated by

V. A. Kostornichenko [10] were taken for numerical studies, given in table 1. 
Table 1.

\begin{tabular}{|c|c|c|c|c|c|}
\hline \multirow{2}{*}{$\begin{array}{l}\text { Sample } \\
\text { code }\end{array}$} & \multirow{2}{*}{$\begin{array}{l}\text { Reinforcement } \\
\text { strength } f_{y}, \mathrm{MPa}\end{array}$} & \multicolumn{2}{|c|}{ Concrete strength, $\mathrm{MPa}$} & \multicolumn{2}{|c|}{ load } \\
\hline & & $f_{\text {c. prism }}$ & $f_{c t m}$ & $\mathrm{~T},{ }^{\circ} \mathrm{C}$ & $\mathrm{P}_{0}$ \\
\hline K8-1 & 477,3 & 34,6 & 1,84 & $150 / 60$ & - \\
\hline K8-2 & 477,3 & 34,6 & 2,00 & $150 / 60$ & + \\
\hline K7-1 & 476,0 & 30,0 & 2,20 & $20 / 60$ & cyclic \\
\hline K7-2 & 476,0 & 31,0 & 2,20 & $20 / 60$ & cyclic \\
\hline K5-1 & 477,5 & 34,8 & 2,00 & $150 / 60$ & - \\
\hline К5-2 & 477,5 & 34,8 & 2,02 & $150 / 60$ & + \\
\hline
\end{tabular}

A feature of the experimental studies [10] was that the internal pressure was created by heated cement, and the thermocouples measured the air temperature at the edges of the annular elements. Table 1 shows the concrete temperature of the outer edge of the ring. The ambient temperature was $20^{\circ} \mathrm{C}$ and convective heat exchange took place.

It was found that the first cracks in the rings were formed at a temperature difference along the height of the cross-section of $\approx 46^{\circ} \mathrm{C}$. The temperature moments of cracking were 2.24-2.48 $\mathrm{kNm}$. The maximum temperature moments, which during short-term tests were $3.0 \mathrm{kNm}$, decreased to $0.85 \mathrm{kNm}$ under prolonged exposure to temperature, and changed sign when cooled to normal temperature and amounted to $-2.4 \mathrm{kNm}$. The moments of cracking depend on the heterogeneity of the concrete along the height of the cross-section, plastic deformations of the concrete and the non-linear temperature distribution in the cross-section. The annular force at which cracks began to form at normal temperature was $35.8 \mathrm{kN}$. With a temperature difference of $110^{\circ} \mathrm{C}$, it decreased to $5.97 \mathrm{kN}$. A decrease in the magnitude of the cracking force by $4.2-5.3 \%$ was revealed with a curvilinear temperature diagram (non-stationary mode). In force tests and normal temperature, through cracking was recorded at a tensile annular force of $30 \mathrm{kN}$.

The crack opening width $w_{\text {crc }}$ in reinforced concrete rings with short-term heating was $0.1 \mathrm{~mm}$, with long-term heating $-0.075 \mathrm{~mm}$. In force tests, the crack opening width did not exceed 0.2 $\mathrm{mm}$ at the level of $80 \%$ of the breaking tensile force in the section. Cooling to normal temperature led to a decrease in the crack opening width to $0.025 \mathrm{~mm}$. 
An increase in the temperature gradient along the height of the cross-section from 40 to $110^{\circ}$ C together with short-term tensile forces from internal pressure at the level of 0.8 from the breaking pressure led to an increase in the width of the opening of normal cracks from 0.25$0.275 \mathrm{~mm}$ to $0.3-0.312 \mathrm{~mm}$, respectively.

The maximum height of non-through normal cracks was $5.9 \mathrm{~cm}$ for the first short-term heating, $6.33 \mathrm{~cm}$ for the long-term first heating, $6.4 \mathrm{~cm}$ for the re-heating. Cooling of the rings after heating led to the formation of through cracks in the cross sections, for which the maximum opening width was fixed with one-sided heating of the inner face. In other cross-sections, the height of non-through cracks was fixed at $3.9 \mathrm{~cm}$.

With prolonged exposure to elevated temperatures and temperature differences along the height of the cross-section, the crack opening width remained practically unchanged. The height and width of the crack opening did not increase with repeated heating of the inner face of the ring. The author [9] concluded that the reason for this was a decrease in temperature moments and the development of concrete shrinkage processes, which compensated each other. The relative deformations of the longitudinal axis of the rings with short-term heating of the inner face of the rings were $(53,7-57,2) \cdot 10^{-5}$, with prolonged heating $19,2 \cdot 10^{-5}$. Since the stress in the concrete in the compression zone of the rings was insignificant, the distribution of deformations along the height was assumed to be linear, and the stress was assumed to be elastic.

In experimental studies, the stress of the most heated compressed face of the concrete of the rings was 2.5-3.0 $\mathrm{MPa}$. The stresses in the longitudinal working reinforcement of the rings, measured in the course of experimental studies, amounted to 38-43 MPa under short-term and long-term exposure to internal pressure. Additional temperature stresses in this case were 20.8524.16 MPa with short-term heating and increased to 100.65-109.26 with prolonged exposure to elevated temperature.

The current standards [10] recommend taking into account additional stresses in the reinforcement from the temperature shrinkage of concrete at the level of $60 \mathrm{MPa}$ and not taking into account the work of tensile concrete in the limiting state. The modulus of deformation of concrete at elevated temperatures of $60-120^{\circ} \mathrm{C}$ decreased by $24-40 \%$, respectively.

According to the results of the analysis of experiments, it is concluded that the establishment of the moment diagram is influenced by the appearance of an additional force $\mathrm{N}_{\text {ctso }}$ (fig. $1 \mathrm{~b}$ ) 
with an eccentricity $e_{o n}$, depending on the development of plastic deformations of concrete and the temperature difference along the height of the ring cross section.

The additional force Nctso, calculated taking into account the already existing balanced diagram of temperature moments in the annular section, was $12.2 \mathrm{kN}$ with short-term heating and $43.0 \mathrm{kN}$ with long-term heating. This force reduced the moment of cracking in the rings by $14 \%$ at a temperature near the inner edge of $60^{\circ} \mathrm{C}$ and by $26 \%$ with an increase in temperature to $150^{\circ} \mathrm{C}$. A decrease in the strength of concrete when heated led to a decrease in the magnitude of the moment of cracking by $3-8 \%$. The nonlinear distribution of temperatures along the height of the cross section during the first short-term heating led to a decrease in the moment of cracking by $5.6 \%$ at a temperature near the inner edge of $60^{\circ} \mathrm{C}$ and by $5.3 \%$ with an increase in temperature to $150^{\circ} \mathrm{C}$. The work of tensioned concrete between cracks in accordance with recommendations of the norms [11] was taken into account using the coefficient $\Psi_{\mathrm{s}}$. It is recommended to take into account the presence of cracks with tensile forces in the ring at the level of $30 \mathrm{kN}$.

\section{Numerical experiment technique}

Numerical studies of ring fragments were carried out in the Lira 10.8 software package by the finite element method in a physically nonlinear formulation. The purpose of the research was to verify the developed algorithms in the formulation of a stationary temperature problem using the provisions of the deformation model, which is adopted in the current standards. The possibility of replacing cost full-scale tests with numerical modeling was tested. As initial data, we used the actual dimensions of the sections, reinforcement of annular specimens and strength reinforcement and concrete (Fig. 1, Table 1). Internal pressure was applied in steps of 0.25 of the maximum, the effect of which caused the appearance of the tensile force in the section, which was achieved in experimental studies. The relationship between the internal pressure $\mathrm{P}_{0}$ and the tensile annular forces was adopted according to the known dependencies of structural mechanics.

The stationary problem of thermal conductivity was modeled taking into account the data of experimental studies - the actual temperature level at the surface of the concrete faces of the rings. In this case, the temperature distribution over the depth of the samples in the numerical experiment corresponded to the physical experiment. 
The concrete ring was modeled using volumetric elements, longitudinal reinforcement and transverse stirrups were modeled using bar elements with appropriate stiffness and location. Temperature loads were applied to the inner and outer parts of the ring. As the physical properties of the base of the ring, characteristics were taken that corresponded to heavy concrete on Portland cement. The boundary conditions ensured free support of the ring on the surface. Two types of temperature boundary conditions for the outer surface of the ring were tested. In the first variant, the boundary condition was a fixed temperature of the outer face of $60^{\circ} \mathrm{C}$. In the second variant, the boundary conditions of Newton-Richman surface heat exchange were applied with the temperature of the outer edge of $60^{\circ} \mathrm{C}$ and the ambient temperature of $20^{\circ} \mathrm{C}$. The second variant made it possible to take into account the fact that in a real experiment the temperature was measured not of the ring itself, but the temperature of the environment that surrounds it.

\section{Comparison and analysis of the results of numerical and physical experiments}

The study of the effect of the tensile strength of concrete on the level of stresses in the reinforcement, the processes of cracking and the deformability of rings was of considerable interest for numerical analysis.

The results of the numerical determination of the crack opening width $w$, the height of the compressed concrete zone $x_{1}$ and the maximum tensile stresses $\sigma_{s 1, \max }$ in the reinforcement are given in Tables 2 and 3. In this case, the crack opening width was calculated according to the method described in [9]. All initial data for this dependence were obtained by the finite element method. Table 2 shows the results of a numerical experiment without taking into account the tensile strength of concrete, which can also simulate the operation of samples with smooth reinforcement, the adhesion of which to concrete significantly deteriorates when heated.

Table 2.

Numerical experiment results $\left(f_{c t m}=0.2 \mathrm{MPa}\right)$

\begin{tabular}{|l|l|l|l|l|l|}
\hline $\begin{array}{c}\mathrm{P}_{0} \\
\mathrm{MPa}\end{array}$ & \multicolumn{1}{|c|}{$\mathrm{T}_{1},{ }^{\circ} \mathrm{C}$} & \multicolumn{1}{c|}{$\mathrm{T}_{2},{ }^{\circ} \mathrm{C}^{*}$} & \multicolumn{1}{c|}{$\sigma_{s 1, \max , \mathrm{MPa}}$} & $x_{1}, \mathrm{~mm}$ & $w_{\text {crc }}, \mathrm{mm}$ \\
\hline 0 & 150 & 60 & 89 & 25 & 0,0433 \\
\hline 0.5 & 150 & 60 & 140 & 0 & 0,111 \\
\hline 1,0 & 150 & 60 & 220 & 0 & 0,215 \\
\hline 1,5 & 150 & 60 & 299 & 0 & 0,317 \\
\hline 2,0 & 150 & 60 & 379 & 0 & 0,421 \\
\hline 2,0 & 20 & 20 & 429 & 0 & 0,486 \\
\hline
\end{tabular}


Note: $*$ - convective heat transfer on the outer part of the ring (Newton-Richmann boundary condition).

$\mathrm{P}_{0}$ - internal pressure, $\mathrm{T}_{1}, \mathrm{~T}_{2}$ - respectively the temperatures inside and outside the ring, $\sigma_{s 1, \max }$ - maximum stress in steel reinforcement, $x_{1}$ - the height of the compressed zone, $w$ - crack opening width.

In the output data, the tensile strength of concrete is conventionally assumed to be close to zero, $f_{c t m}=0,2$ МПа. A similar assumption is made in [9] when calculating crack opening. Table 3 shows the results of a numerical experiment taking into account the work of tensioned concrete between cracks. The designations in the tables are adopted in accordance with [9].

Table 3.

Numerical experiment results $\left(f_{\text {ctm }}=2.02 \mathrm{MPa}\right)$

\begin{tabular}{|l|l|l|l|l|l|}
\hline $\begin{array}{c}\mathrm{P}_{0} \\
\mathrm{MPa}\end{array}$ & \multicolumn{1}{|c|}{$\mathrm{T}_{1},{ }^{\circ} \mathrm{C}$} & \multicolumn{1}{|c|}{$\mathrm{T}_{2},{ }^{\circ} \mathrm{C}^{*}$} & \multicolumn{1}{|c|}{$\sigma_{s 1, \max , \mathrm{MPa}}, \mathrm{mm}$} & $w_{c r c}, \mathrm{~mm}$ \\
\hline 0 & 150 & 60 & 68 & 0,05 & 0,0245 \\
\hline 0,5 & 150 & 60 & 79 & 0,0375 & 0,0339 \\
\hline 1,0 & 150 & 60 & 95 & 0,0125 & 0,0488 \\
\hline 1,5 & 150 & 60 & 148 & 0 & 0,121 \\
\hline 2,0 & 150 & 60 & 226 & 0 & 0,222 \\
\hline 2,0 & 20 & 20 & 223 & 0 & 0,218 \\
\hline
\end{tabular}

Note: * - convective heat transfer on the outer part of the ring (Newton-Richmann boundary condition).

Designation similar to Table 3

The temperature tensile stresses in the reinforcement of the annular specimen, obtained by numerical simulation, significantly depend on the accounting or neglect of the concrete tensile work. Failure to take into account the work of tensioned concrete led to an increase in the level of stresses in the reinforcement from $19-31 \%$ to almost double at normal temperatures.

The experimental crack opening width in annular specimens under the action of internal pressure and temperature load was compared with that obtained in a numerical experiment. At normal temperature, the deviation of the numerical values of the crack opening width from the experimental ones was about $9 \%$, with short-term heating - 19\%, with thermal power loads $16-20 \%$, taking into account the work of concrete between the cracks. The maximum crack opening width of $0.218 \mathrm{~mm}$ did not exceed the limit values in accordance with the current standards [9]. 
The displacements $\Delta$ and deformations of the most compressed and most stretched extreme concrete fibers of the section of annular specimens determined in a numerical experiment are given in Tables 4 and 5.

Table 4.

Displacements and deformations of annular specimen faces $\left(f_{c t m}=0.2 \mathrm{MPa}\right)$

\begin{tabular}{|c|c|c|c|c|c|c|c|c|}
\hline $\begin{array}{c}\mathrm{P}_{0}, \\
\mathrm{MPa}\end{array}$ & $\mathrm{T}_{1},{ }^{\circ} \mathrm{C}$ & $\begin{array}{c}\mathrm{T}_{2},{ }^{*} \\
{ }^{\circ} \mathrm{C}\end{array}$ & $\begin{array}{c}\Delta^{\prime}, \\
\mathrm{mm}\end{array}$ & $\begin{array}{c}\Delta, \\
\mathrm{mm}\end{array}$ & $\begin{array}{c}\sum \varepsilon_{\mathrm{c}(1)} \\
10^{-5}\end{array}$ & $\begin{array}{c}\sum \varepsilon_{\mathrm{c}(2)} \\
10^{-5}\end{array}$ & $\varepsilon_{\mathrm{c}(1)}, 10^{-5}$ & $\varepsilon_{\mathrm{c}(2)}, 10^{-5}$ \\
\hline 0 & 150 & 60 & 0,553 & 0,743 & 138,2 & 123,9 & $-12,0$ & 63,9 \\
\hline 0.5 & 150 & 60 & 0,699 & 0,878 & 174,7 & 146,4 & 24,7 & 86,4 \\
\hline 1,0 & 150 & 60 & 0,937 & 1,098 & 234,3 & 183 & 84,3 & 123 \\
\hline 1.5 & 150 & 60 & 1,176 & 1,318 & 293,9 & 219,7 & 143,9 & 159,7 \\
\hline 2,0 & 150 & 60 & 1,414 & 1,538 & 353,6 & 256,3 & 203,6 & 196,3 \\
\hline 2,0 & 20 & 20 & 0,907 & 0,836 & 226,8 & 139,3 & 226,8 & 139,3 \\
\hline
\end{tabular}

Note: * - convective heat transfer on the outer part of the ring (Newton-Richmann boundary condition)

$\mathrm{P}_{0}$ - internal pressure, $\mathrm{T}_{1}, \mathrm{~T}_{2}$ - respectively the temperatures inside and outside the ring, $\Delta^{\prime}$ and $\Delta$ are, respectively, the radial displacements of the inner and outer parts

кільця, $\sum \varepsilon_{\mathrm{c}(1)}, \sum \varepsilon_{\mathrm{c}(2)}$ - total deformations taking into account thermal expansion

on the inner and outer parts of the ring, $\varepsilon_{\mathrm{c}(1)}, \varepsilon_{\mathrm{c}(2)}$ are the sum of elastic and plastic deformations on the inner and outer parts of the ring, respectively.

Table 5.

Displacements and deformations of annular specimen faces $\left(f_{c t m}=2.02 \mathrm{MPa}\right)$

\begin{tabular}{|l|l|l|l|l|l|l|l|l|}
\hline $\begin{array}{c}\mathrm{P}_{0,} \\
\mathrm{MPa}\end{array}$ & $\begin{array}{l}\mathrm{T}_{1}, \\
{ }^{\circ} \mathrm{C}\end{array}$ & $\begin{array}{c}\mathrm{T}_{2}, * \\
{ }^{\circ} \mathrm{C}\end{array}$ & $\begin{array}{c}\Delta^{\prime}, \\
\mathrm{mm}\end{array}$ & $\begin{array}{c}\Delta, \\
\mathrm{mm}\end{array}$ & $\begin{array}{l}\sum_{\mathrm{c}_{\mathrm{c}(1)},} \\
10^{-5}\end{array}$ & $\begin{array}{l}\sum_{\varepsilon_{\mathrm{c}(2)},} \\
10^{-5}\end{array}$ & $\varepsilon_{\mathrm{c}(1)}, 10^{-5}$ & $\varepsilon_{\mathrm{c}(2),}, 10^{-5}$ \\
\hline 0 & 150 & 60 & 0,494 & 0,688 & 123,6 & 114,6 & $-26,0$ & 54,6 \\
\hline 0.5 & 150 & 60 & 0,530 & 0,720 & 132,5 & 120 & $-18,0$ & 60 \\
\hline 1,0 & 150 & 60 & 0,579 & 0,765 & 144,7 & 127,5 & $-5,3$ & 67,5 \\
\hline 1.5 & 150 & 60 & 0,736 & 0,910 & 184,1 & 151,7 & 34,1 & 91,7 \\
\hline 2,0 & 150 & 60 & 0,974 & 1,130 & 243,5 & 188,3 & 93,5 & 128,3 \\
\hline 2,0 & 20 & 20 & 0,470 & 0,431 & 117,4 & 71,9 & 117,4 & 71,9 \\
\hline
\end{tabular}

Note: * - convective heat transfer on the outer part of the ring (Newton-Richmann boundary condition)

Designation similar to Table 4 
The height of cracks obtained in a numerical experiment using dependence (1) was $75.8 \mathrm{~mm}$ and differed from the experimental values by $18-20 \%$ for all test modes.

$$
\varepsilon_{c t u}=-2 f_{c t m} / E_{c d}
$$

All designations are adopted in accordance with [9]. In this case, the generalized coefficient of the deformation modulus reduction from the temperature of 0.60 at the crack tip was used. Failure to take into account the work of concrete in tension leads to an increase in the deviations of the width of the opening and the height of the cracks in the experimental values. The maximum crack opening width of $0.445 \mathrm{~mm}$ at thermal power loads and $0.486 \mathrm{~mm}$ at normal temperature significantly exceeds the limit values given in the current standards [9].

In the numerical experiment with the first short-term heating and the action of the maximum internal pressure, the radial displacements of the rings were $1.538 \mathrm{~mm}$ without taking into account the work of stretched concrete and $1.13 \mathrm{~mm}$ taking into account stretched concrete. With prolonged heating of the inner face to $150^{\circ} \mathrm{C}$ and the maximum internal pressure, the radial displacements of the rings were $0.743 \mathrm{~mm}$ without taking into account the work of stretched concrete and $0.688 \mathrm{~mm}$ taking into account stretched concrete. Long exposure at a temperature of $150{ }^{\circ} \mathrm{C}$ led to a twofold increase in displacements.

Under thermal and force loads, the principle of superposition was preserved, i.e., the summation of displacements from various factors. Long-term one-sided heating of the rings corresponds to large displacement values, since in this case irreversible plastic deformations of concrete are fully manifested. Comparison of experimental displacements with the results of a numerical experiment showed that for specimens with bar reinforcement, as well as for specimens with external sheet reinforcement [1,3], under short-term exposure to load and temperature, radial displacements can be defined as for structures operating in the elastic stage. With prolonged exposure to temperature loads, calculations should take into account the effect of irreversible plastic deformations.

\section{Conclusions.}

Based on the results of comparing the results of a numerical experiment and experimental studies of crack resistance and deformability of annular specimens under the action of thermoforce loads, their analysis and comparison, the following conclusions can be drawn. 
1.Computer simulation of reinforced concrete three-layer annular fragments of protective structures showed the possibility of using a numerical experiment and existing algorithms in the formulation of a stationary thermoelasticity problem to determine with high accuracy the stress-strain state of samples in the mode of stationary short-term and long-term heating and the action of internal pressure. When using a deformation model that takes into account the work of tensile concrete between cracks, deviations from the experimental data were within 8$20 \%$.

2. The stresses in the reinforcement and concrete of a three-layer annular fragment obtained in a numerical experiment under the action of force and thermo-force loads in the formulation of the stationary thermoelasticity problem showed good agreement with the results of experimental studies on full-scale models. The deviation did not exceed 7-10\% when taking into account the tensile work of the concrete section. Without taking into account such work, deviations exceeded $90 \%$.

3.The nonlinear deformable model adopted in the current standards [9], taking into account the real deformation diagrams of concrete and reinforcement, reliably describes the processes occurring in the structure and allows to unambiguously determine its stress-strain state at all load levels, including the limiting state.

\section{References}

1. Report No.01850016741, research work on the topic "Development and study of strength and deformability of structures of sealing heat storage tanks with the inclusion of a new type of sheet reinforcement in a reinforced concrete section". - Lvov: LOLPI, 1989.- 96 p. (contract No.4172 - responsible performer).

2. L.N. Gakhova. Temperature-induced stresses in reinforced structures. Geodynamics and Stress State of the Earth`s Interior (GSSEI 2017). IOP Conf. Series: Earth and Environmental Science 134 (2018) 012021, doi: 10.1088/1755-1315/134/1/012021.

3. I. I. Karkhut, O. V. Krochak, S. B. Maksimovich. Modeling the reinforced concrete shell with a protective structure. Mathematical modeling and computing. Volume 8, Number 3, 2021, pp. 391-399. DOI: https://doi.org/10.23939/mmc2021.03.391.

4. I.I. Karkhut. Temperature loads on reinforced concrete protective structures. Lviv, 2015, publishing house "LP" - $248 \mathrm{p}$.

5. J.J. Luchko, B.B. Kovalchuk, II Karhut. Thermal stress state of structural concretes, reinforced concrete and reinforced concrete structures and bridges. Lviv, 2020, Publishing House "Svit" - 326 p. 
6. Raghupati Roy, U.S.P. Verma and A.S. Warudcar. Analisis of Massive Reinforced Concrete Ring Beam of Nuclear Containment Structure due to Heat of Hydration. Transactions of the $15^{\text {th }}$ International Conference on Structural Mechanics in Reactor Technology (SMiRT 15). Seoul, Korea, August 15-20, 1999.

7. M. Briffaut, F. Benboudjema, J.M. Torrenti, G. Hanas. Numerical analysis of the thermal active restrained shrinkage ring test to study the early age behavior of massive concrete structures. Engineering structures. Vol. 33, issue 4. April 2011. Pages 1390-1401.

8. M. Slijepcevic, R. Vukomanovic, G. Broceta. Stress distribution in concrete chimneys due to elevated temperatures. $1^{\text {st }}$ International Symposium Students FOr Resilient soCiEty (SFORCE 2018), Novi Sad, September 28-29, 2018. Conference paper, February 2019.

9. DSTU B V.2.6-156:2010 Concrete and reinforced concrete structures made of heavy concrete. Design rules. Kyiv, 2011. State Enterprise "Ukrarchbudinform" - 118 p.

10. Krichevsky A.P. Calculation of reinforced concrete engineering structures taking into account temperature influences - M., 1984. Stroyizdat - 148 p.

11. SNiP 2.03.04-84 Concrete and reinforced concrete structures intended for operation in conditions of exposure to elevated and high temperatures. - M, 1985. Gosstroy of the USSR $54 \mathrm{p}$. 


\title{
Corruption in the Economy of Ukraine
}

\author{
Kofanov Andrii \\ Legal Advisor to the Council of Europe Programme "Decentralization and \\ Territorial Consolidation in Ukraine”, PhD of Juridical Sciences, Associate \\ Professor, Professor of Department of Forensic Support and Forensic Expertise \\ of the National Academy of Internal Affairs, Kiev, Ukraine \\ ORCID ID 0000-0002-5242-2518 kofanov_andrey@ukr.net
}

\author{
Pavlovska Nataliia \\ PhD of Juridical Sciences, Associate Professor, Associate Professor of Theory \\ and History of Law, Kyiv National Economic University, Kiev, Ukraine \\ ORCID ID 0000-0003-3311-0364 wwwpav@gmail.com \\ Kulyk Maryna \\ PhD of Juridical Sciences, Associate Professor of Criminal Produce of the \\ National Academy of Internal Affairs, Kyiv, Ukraine \\ ORCID ID 0000-0003-1373-6749 coolss777@ukr.net
}

\author{
Tereshchenko Yuliia \\ PhD of Juridical Sciences, Professor of the Department of Criminal Procedure \\ of the National Academy of Internal Affairs, Kyiv, Ukraine \\ ORCID ID 0000-0002-5353-0887_vladysikter@ukr.net
}

\author{
Symchuk Anatolii \\ Senior Teacher at the Department of Criminal Procedure of the National \\ Academy Internal Affairs, Kyiv, Ukraine \\ ORCID ID 0000-0002-8663-8210 symchukas@gmail.com
}

\begin{abstract}
The research was conducted on the basis of the method of system analysis and generalization of information obtained during the survey conducted by different categories of law enforcement officers who carry out pre-trial investigation of the said crimes, as well as reports from the Ministry of Internal Affairs of Ukraine, the National Police of Ukraine, National Anti-Corruption Bureau of Ukraine, etc. for 2016-2019. The most relevant motives and methods of committing corruption crimes were analyzed and found that bribery and corruption were the first among economic crimes, and the increase in the number of these crimes was facilitated by the high corruption of state bodies in various spheres of public life. The key issues that will reduce the level of corruption in the state are outlined.

Keywords: National Anti-Corruption Bureau (NABU), investigation of criminal proceedings, corruption, organized economic crime.
\end{abstract}


Introduction These are the National Agency for the Prevention of Corruption (NAPC), the National Agency for the Identification, Search and Management of Assets Obtained from Corruption and Other Crimes (ARMA), the National Anti-Corruption Bureau (NABU) and the Specialized Anti-Corruption Prosecutor's Office (SACPO). ARMA is similar to the return and asset management institutions and operates successfully in EU member states; one of the main functions of the NAPC is to verify the declarations of officials; NABU detectives investigate corruption crimes at the highest level of government. The SACPO assess this investigation and refer criminal proceedings to the court, where they support the prosecution during the proceedings (Tab. 1-3).

Starting in 2015, the first criminal proceedings on embezzlement of funds of state enterprises for the total amount of about 1 billion hryvnia were included in the Unified Register of Pre-Trial Investigations (URPI). As of February 1, 2016, the Office's detectives are entering 56 proceedings into the pre-trial investigation register. Most of the proceedings -19 were referred to the Office by the Attorney General's Office. Fifteen production facilities are included in URPI on the basis of own developments of detectives and analysts of the Bureau, as well as on the basis of information provided by individuals and legal entities. However, it should be noted that in 2016, the most corruption-related crimes were detected by the national police (Fig. 1).

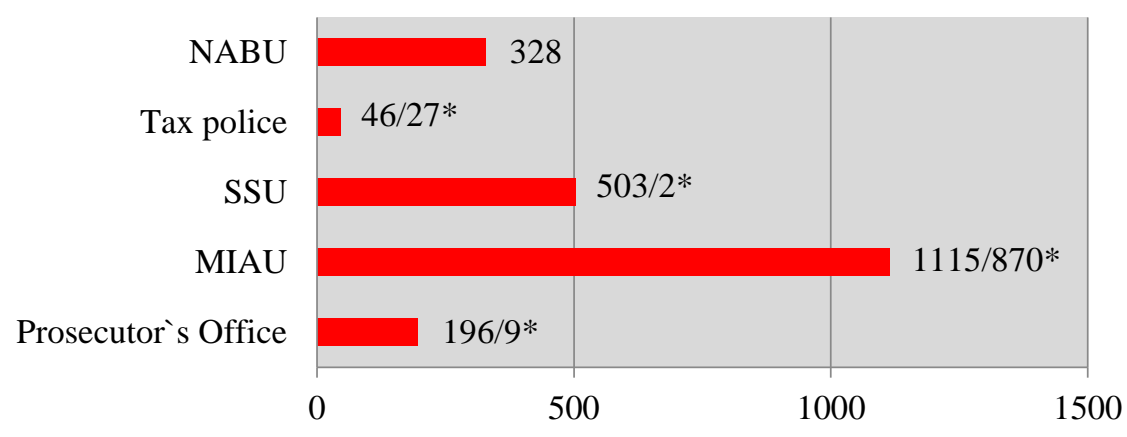

Figure 1. The number of criminal proceedings filed in the Unified Register of Pre-Trial Investigations 2016/*5 months of 2017 [1]

In terms of types of economic activity, most of the proceedings are related to the spheres of public administration, defense, compulsory social insurance - 22; transport, warehousing, postal and courier activities -6 ; electricity, gas, steam and air conditioning -5 , as well as financial and insurance activities. In the context of persons subject to verification of 
involvement in corruption offenses, most of the proceedings concern the activities of heads of state enterprises -19 proceedings, judges -13 proceedings, civil servants and officials of local self-government 1 and 2 categories -11 proceedings, senior officials -6 , prosecutors -5 .

In accordance with article 65 of the Law of Ukraine "On prevention of corruption" from 14.10.2014 №1700-VII "persons specified in the first part of article 3 of the Law, for committing corruption or corruption-related offenses in accordance with the procedure established by law are subject to criminal [2], administrative, civil [3] and disciplinary liability" [4].

Within the framework of the pre-trial investigation of criminal proceedings, the first arrests for cash in hryvnias and foreign currency were imposed - UAH 400,7 thousand, USD 109 thousand, EUR 2.4 thousand, 2 thousand RUB. Also, applications were filed in the amount of 346.2 million UAH.

For 2014-2018, 15.8 thousand bribe-takers were revealed. The general tendency of the results of the fight against bribery has improved somewhat, both by the number of exposed bribes ( $+7 \%$ for 2018 vs. 2014) and by the share of bribery in the total number of crimes in the field of official activity (15\% in 2014 against 18\% in 2018). Only in 2018 were bribery cases of 1800 worth 60.7 billion UAH, including 179 bribes, the amount of which exceeded 100 thousand UAH (for the five-year period of such crimes disclosed 585). The number of bribes amounting to more than UAH 250 thousand has more than doubled in 2018 compared to 2014.

Table 1.

Distribution of proceedings according to sources of information [5]

\begin{tabular}{|c|c|c|}
\hline Criminal proceedings & $\begin{array}{c}\text { Only active } \\
\text { proceedings as } \\
\text { of } \\
31.12 .2016\end{array}$ & $\begin{array}{c}\text { Only active } \\
\text { proceedings as } \\
\text { of } \\
31.12 .2017\end{array}$ \\
\hline $\begin{array}{l}\text { registered on the basis of applications of individuals } \\
\text { and legal entities received by the NABU }\end{array}$ & 19 & 12 \\
\hline $\begin{array}{l}\text { registered for detectives and analysts`s own } \\
\text { developments }\end{array}$ & 31 & 23 \\
\hline $\begin{array}{l}\text { registered by detectives based on statements and } \\
\text { reports of Ukrainian deputies }\end{array}$ & 2 & 1,5 \\
\hline $\begin{array}{l}\text { Transmitted by the Attorney General's Office and } \\
\text { other law enforcement units }\end{array}$ & 31 & $31+3,3$ \\
\hline Other: & & \\
\hline
\end{tabular}


registered on the basis of materials from other law enforcement units

registered by court order

\begin{tabular}{|l|r|}
\hline 8 & 6,1 \\
\hline 9 & 21 \\
\hline
\end{tabular}

In terms of the typology of offences, the most crimes investigated by the Detectives of Bureau fall within the scope of article 191 of the Criminal Code - "Appropriation, embezzlement or appropriation of property by abuse of office" ( 88 proceedings); the second most common article is article 364 of the Criminal Code - "Abuse of power or official position" (53 proceedings); and the third largest number of offences under article 368 of the Criminal Code - "Acceptance of an offer, promise or receipt of an undue advantage by an official" (45 proceedings).

Table 2.

The activity of NABU [6]

\begin{tabular}{|l|c|c|}
\hline & as of 31.12 .2017 & as of 31.12 .2018 \\
\hline Criminal proceeding in work & 487 & 635 \\
\hline Criminal proceedings referred to the court & 107 & 176 \\
\hline The amount of damage caused by crimes & 153,3 billion $z$ & 220,02 billion $z$ \\
\hline Was indemnified for damages & 253,3 million $z$ & 452,37 million $z$ \\
\hline
\end{tabular}

Table 3.

Information about combating economic crimes [7]

\begin{tabular}{|l|c|c|c|}
\hline Criminal offences in the Budget sphere & 2016 & 2017 & 2018 \\
\hline Administrative protocols on corruption have been drawn up & 2449 & 3504 & 3700 \\
\hline
\end{tabular}


Crimes in the sphere of economic activity are revealed

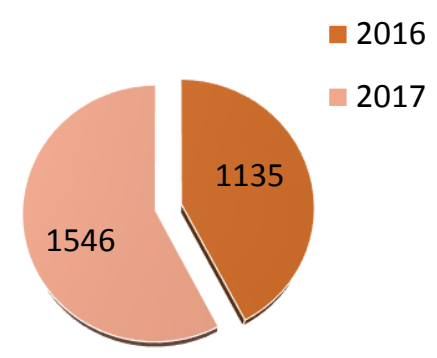

Crimes in the field of official activity are revealed

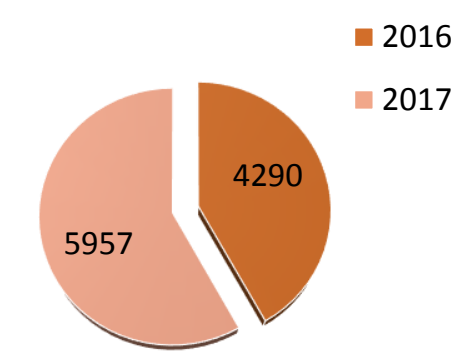

Crimes related to the use of budget funds are revealed

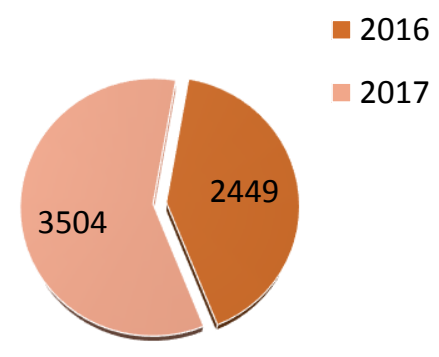

Figure 2. The results of police work in countering economic crimes [8]

As of June 30, 2018, appropriation, misappropriation or seizure of property by abuse of office - $33.5 \%$ (Article 191 of the Criminal Code of Ukraine), acceptance of a proposal, promise or obtaining an unlawful benefit by an official - $26.9 \%$ (Article 368 of the Criminal Code of Ukraine), abuse of power or official position - $11 \%$ (Article 364 of the Criminal Code of Ukraine), fictitious business - $3.5 \%$ (Article 205 of the Criminal Code of Ukraine), creation of a criminal organization - $2.6 \%$ (Article 256 of the Criminal Code of Ukraine) [9].

The most common deficiencies in the interaction of special units in the fight against economic crime are the following: insufficient exchange of information (concealment) $-25 \%$ of respondents, inconsistency of actions $-20 \%$, conflict of interests $-15 \%$, low qualifications and poor vocational training $-12 \%$.

Regarding shortcomings in the exchange of information between regulatory and law enforcement units, $25 \%$ of respondents indicated that full information is not provided; $14 \%$ that there is no legislatively established mechanism for implementing the exchange of information; $10 \%$ - insufficient technical capabilities for reference information exchange; $7.2 \%$ - the actual lack of information sharing. In addition, the respondents drew attention to the violation of the deadlines for completing assignments; the existence of internal "card systems" of indicators (as a result, everyone works only on "his" indicator); lack of close cooperation; parallelism of work of many services and duplication of functions; unhealthy competition and rivalry even within one unit, and even more so with other departments; formalism in solving specific issues; lack of bilateral exchange of information; insufficient level of professional training of employees of supervisory authorities and so on (Materials of the survey conducted 
by the employees of various special units) [10].

\section{DISCUSSION AND CONCLUSION}

The research results give the following conclusions: 1. The problem of corruption and organized economic crime in Ukraine has become quite threatening. It has received wide distribution in all spheres of society, among all branches of government. 2. Corruption among the ruling political and economic elite has become the norm of behavior, not the exception. It remains inaccessible to law enforcement units, which themselves are partially affected by corruption and do not have sufficient opportunities to combat it. 3. Corruption and organized economic crime have gone beyond state borders and undermine state and international institutions of power and economy, threaten social institutions, democracy, human rights, moral principles of society, and impede economic development [11]. 4. Anti-corruption legislation is applied only selectively, mainly with respect to the lowest categories of public servants and officials or individual high-ranking officials who have extremely discredited themselves in the eyes of the public and their own elite. 5. Purposeful fight against corruption cannot be carried out as a result of one-time and short-term actions of any degree of activity and rigor at any level, but needs long-term socio-economic, political and legal transformations. This activity should be based on a combination of preventive and repressive measures. At the same time, the priority role should be given to preventive measures in general social and specially criminological nature, which would create a transparent system for effective state and public control.

In order to improve the activities of special units that carry out the detection of corruption and economic crimes, it is necessary: resolve the conflict existing in the current legislation regarding the procedure for providing information to law enforcement units regarding the funds and property of certain legal entities and individuals; to unify and specify in a single legislative act the conditions and procedure for the provision of marked information to law enforcement and other authorities; to determine the specific mechanisms of interaction of special units that carry out the detection of malfeasance with other units, to which the legislation imposes the obligation of operational, technical, informational and other support for activities [12].

\section{References}

1. Source: https://mvs.gov.ua/ua/infographic/ 
2. Kryminal'nij kodeks Ukrai'ny [Criminal Code of Ukraine] URL: https://zakon.rada.gov.ua/laws/show/2341-14

3. Cyvil'nij kodeks Ukrai'ny [Civil Code of Ukraine] URL: https://zakon.rada.gov.ua/laws/show/435-15

4. Pro zapobigannja korupcii': Zakon Ukrai'ny vid [On prevention of corruption: Law of Ukraine of] 14.10.2014 №1700-VII URL:https://zakon.rada.gov.ua/laws/show/1700-18

5. Source: https://nabu.gov.ua

6. Source: https://nabu.gov.ua

7. Source: https://mvs.gov.ua/ua/infographic/

8. Source: https://www.slideshare.net/Police_Ukraine/12-2017-86017535

9. Reports from the of NABU, 2018

10. Dudnikov A. On the interaction of law enforcement and controlling authorities in the investigation of economic crimes committed by organized groups. Materials of the final conference of the joint Ukrainian-American research program of the Academy of Legal Sciences of Ukraine and the National Institute of Justice of the Department of Justice of the United States. Kharkiv, Ukraine, 2001. pp. 46-49.

11. Kofanova O., Tereshchenko Yu., Kutsyi R., Morhun N. \& Gushchyn O. Actual situation of computer crime in the credit and financial sphere of Ukraine (modern aspects). Banks and Bank Systems. 2019, vol. 14, no. 1, pp. 172-180. DOI: 10.21511/bbs.14(1).2019.15

12. Bogatyrev I., Topchiy V., Koropatnik I., Kotliarenko O. \& Kofanov A. Problems and perspectives for attracting investments in economy of Ukraine. Investment Management and Financial Innovations, 2019. vol. 16, no. 2, pp. 195-205. DOI: $\underline{10.21511 / \mathrm{imfi} .16(2) .2019 .17}$ 


\title{
Current State of Issues and Perspective of Judicial and Judicial- Expert Activity Improvement in Ukraine
}

\author{
Kotlyarenko Lidiya \\ Doctor of Biological Sciences, Professor, \\ Professor of Department of theory, methodology and organisation of physical \\ training and sports of the National University of Defence of Ukraine
}

ORCID ID 0000-0001-5237-8564 lida_oleg@ukr.net

\section{Pavlovska Nataliia}

PhD of Juridical Sciences, Associate Professor, Associate Professor of Theory and History of Law, Kyiv National Economic University, Kiev, Ukraine

ORCID ID 0000-0003-3311-0364 wwwpav@gmail.com

\section{Komarynska Yuliia}

PhD of Juridical Sciences, Associate Professor, Professor of Department of Criminology and Forensic Medicine of the National Academy of Internal

Affairs, Kiev, Ukraine

ORCID ID 0000-0002-1747-1816 ubk2006@ukr.net

\section{Nesen Olha}

Professor of the Department of Criminalistics and Forensic Medicine National Academy of Internal Affairs, Kyiv, Ukraine Candidate of Medical Sciences, Associate Professor ORCID ID 0000-0001-9340-815X katynesen@gmail.com

\section{Kotliarenko Oleksandr}

PhD in Law, Colonel Chief, Military Law Research Division, Center for Military and Strategic Studies, Ivan Chernyakhovskyi National Defense

University of Ukraine, Kyiv, Ukraine

ORCID ID 0000-0001-8776-2515 lida_oleg@ukr.net 


\begin{abstract}
Modern globalization and integration of international norms into the national legislation offers new challenges and priorities for the transposition of international standards into forensic activities of Ukraine.

The study of foreign practice of regulating forensic activities provides new opportunities to improve the quality and professional competence of forensic examinations conducted by respective institutions. Successful accession to the European community is dependent on internal democratic development, achieving new quality of society, and irreversible democratic transformations in all spheres of social life [1].

Keywords: Criminal Procedure Code of Ukraine an investigator, expert, implementation, international standards, examination, procedures, Civil Procedural Code of Ukraine.
\end{abstract}

Introduction. The concept of 'inner conviction' is used in many legal acts and scientific literature.

Thus the Civil Procedural Code of Ukraine enshrines the rule that the question of sufficiency of the evidence to establish the circumstances relevant to the case, the court decides in accordance with its inner conviction. (Article 80).

The court also evaluates evidence based on its inner conviction proceeding from a comprehensive, complete, objective and direct study of the evidence available in the case (Article 89) [2].

According to Article 94 Criminal Procedure Code of Ukraine an investigator, prosecutor, investigating judge, or court, based on their belief, which is based on a comprehensive, complete and impartial investigation of all the circumstances of criminal proceedings, shall, in accordance with the law, evaluate each evidence in terms of its suitability, admissibility, reliability, and the totality of evidence collected in terms of sufficiency and interrelation for making the appropriate procedural decision. According to Article 388 of the Criminal Procedural Code of Ukraine jurors take the following oath: "I, (full name), hereby swear to perform my duties honestly and impartially, take into account only the evidence examined in court, be guided by the law, my inner conviction and conscience, as befits a free citizen and a fair person." [3].

Similar rules regarding the decision of the court, based on its inner conviction, the issue of the sufficiency of the evidence to establish the circumstances relevant to the case, exist in the Economic Procedural Code of Ukraine (Articles 79, 86) and in the Administrative Procedure Code of Ukraine (Article 76). However these norms fail to define the concept of 'inner conviction' [4]. 
Such subjective factor as internal conviction of a forensic expert based on objective data obtained in the course of examination of objects of expert evaluation is not excluded but also plays an essential role in forensic analysis [5].

The processes of forming inner conviction of a forensic expert, although they have common aspects with judges and jurors however, significant differences do not allow to treat them as similar [6].

The principle of 'equality of the parties to legal proceedings' provides for equality of their procedural opportunities. Under current conditions, there is no equal opportunity for the prosecution and the defense to resort to special knowledge.

On the other hand, a dubious understanding of competition in criminal proceedings leads to discussions about the feasibility of introducing 'defense examination" and 'prosecution examination', about 'competition of experts' or 'competition of expert opinions'.

The development of the institute of 'requisite knowledge' and the elaboration of the basics of 'forensic examination' entails a legitimate question about their relationship with forensic knowledge. The solution to this problem is related to the limits of criminology and its subject area.

This problem is particularly relevant since the legal acts regulating forensic expertise attempt to classify special knowledge and identify types of forensic examinations.

In addition, these classifications are of a rather dubious nature. Today, the problem of attributing certain examinations to the class of forensic is debatable [7].

In particular, according to Subparagraph 1.2.1 of Paragraph 1.2 Section I of the Instruction concerning appointment and conduct of forensic examinations and expert research, approved by Order of the Ministry of Justice No. 53/5 of October 8, 1998 as amended by the Order of the Ministry of JusticeNo.1350/5 of July 27, 2015 as amended by the Order of the Ministry of Justice No. 83/5 of January 10, 2019 forensic examination shall comprise handwriting examination, linguistic examination of speech, technical examination of documents, examination of weapons and tracks and the circumstances of its use, technical (research signs of damage to the clothing associated with concurrent injuries, which are held in forensics office); graphic arts, portrait; examination of the holograms; video recording; explosive; industrial explosions; materials, substances and products (paints and coatings; polymeric materials; fibrous materials; fuel and lubricants; glass, ceramics; narcotic drugs, psychotropic 
substances, their analogues and precursors; alcohol mixtures; soils; metals and alloys and their products; presence of harmful substances (pesticides) in the environment; substances of chemical production and specialty chemicals; food products; strong and toxic substances); biological.

It should be noted that according to Article 92 of the Constitution of Ukraine, the basis of judicial expertise is determined exclusively by the laws of Ukraine. It can be concluded that departmental instructions and regulations concerning forensic activities should apply exclusively to employees of departments that have adopted such standards and should not apply to civil law relations for the provision of expert services by persons who are not employees of state forensic institutions [8].

The negative factors that limit the rights of the defense party may include the use of the term 'forensic examination' in the legal acts of Ukraine, the essence of which in modern conditions does not fully correspond to its form (name).

The definition of the term 'forensic examination' is very vague and has no clear differential features which would allow it to be allocated to a separate class of forensic examination [9].

Limiting the exclusive right to conduct forensic, forensic medical and forensic psychiatric examinations only to state specialized institutions (Article 7) reflects the 'monopoly' of state specialized institutions in performing certain types of forensic examinations, deprives experts who do not work in these institutions of the opportunity to conduct expert research (deprivation of the profession of an expert).

The restoration of justice should be connected with the possibility of inviting independent experts, conducting alternative examinations, and a wide range of opportunities for applying special knowledge [10].

Among other things, there is an issue of the speed of legal proceedings. The monopoly that is currently observed with examinations delays the very examination process.

For instance, the National Anti-corruption Bureau of Ukraine (hereinafter referred to as $\mathrm{NABU}$ ) notes that sometimes they have to wait quite a long time for the examination required for the further pre-trial investigation of the case (when e.g. there are limited terms of a pre-trial investigation), which directly affects the quality and possibility of bringing the case to court. 
In addition, the existing legislation regarding expertise contradicts the Law of Ukraine 'OnNational anti-corruption Bureau of Ukraine ' No. 1698-18, which indicates that NABU detectives have the right to attract specialists and experts at their discretion (including foreign ones), while the court appoints an expert at its discretion [11].

The change in the procedure of involving an expert in criminal proceedings requires attention. In particular, Article 243 of the Criminal Procedure Code of Ukraine (hereinafter referred to as the CPC of Ukraine) specifies that an expert is involved if there are grounds for conducting an examination on behalf of an investigating judge or court, provided at the request of a party to criminal proceedings.

In this case, the investigator is actually deprived of the right to decide on the involvement of an expert. Article 244 CPC of Ukraine sets the procedure for consideration by an investigating judge of a request for an expert examination.

Certain attempts to establish the "adversarial nature of the parties" are reflected in Article 245 CPC of Ukraine "Obtaining samples for examination".

This provision of the law states that 'if it is necessary to obtain samples for examination, they are taken by the party to the criminal proceedings who requested the examination or upon whose request the examination was appointed by the investigating judge'. At the same time, the procedure for obtaining samples is not actually defined, especially with regard to the actual mechanisms of action on the part of the defense.

To ensure equal opportunities in obtaining samples for comparative research, the legislator allowed the parties to the criminal proceedings to have temporary access to items and documents and, if necessary, to withdraw them (Articles 160-166 of the CPC of Ukraine), as well as to receive samples for examination (Article 245 of the CPC of Ukraine). The question arises: Is it possible to ensure parity of the parties to criminal proceedings in converting these opportunities? [12].

New trends and the latest technologies for conducting examinations encourage scientists to pay attention to digital technologies that can be used not only for good but also with criminal intent. The latest United Nations report, "The Age of Digital Interdependence" - presented in early summer 2019 - addressed the challenges humanity faces in the digital age. In the spring of 2019, the OECD in its report 'Solving Tax Problems of the Digital Economy" thoroughly 
investigated changes in the tax sphere, the principles of income generation through digital tools, including cryptocurrencies [13].

The year 2017 was a turning point in the crypto economy: financial institutions introduced bitcoin futures, major investors began to enter the crypto market, cryptocurrency became a means of accumulation and saving. It becomes obvious that further ignoring of the cryptocurrency is impossible.

Today, the lack of independent legal regulation of creation ('mining') and circulation ('trading') of cryptocurrencies in Ukraine, as well as the lack of appropriate methods for conducting forensic examination generates a legislative vacuum [14].

Currently a new direction of scientific research is being opened, which requires the attention of judicial experts, lawyers, investigative bodies, and courts to this problem.

In particular, the research staff of the Odessa Scientific Research Institute of Forensics (SRIF) is developing a relevant scientific topic.

Conclusion. The situation in forensic science in Ukraine, in particular in matters related to the implementation of forensic activity in court proceedings, requires further elaboration and clarification, taking into account the reform of the judicial system and the development of new trends and new technologies for conducting examinations.

\section{References}

1. G. Filonenko. Democratization of Ukrainian society as a fundamental component of Ukraine's entry into the European space. Veche. 2011. \# 2 (Jan.). P. 12.

2. M.Khaustova. International standards in the context of European integration processes in Ukraine. Journal of National Academy of Legal Sciences of Ukraine \#2 (89) Pp. 44-45.

3. O.Oleinik. Foreign experience of administrative and legal regulation of forensic activities. Customs Business. 2013. No. 4 (88) P. 270.

4. G.K.Avdeeva. Problems of harmonization of Ukrainian legislation in the field of forensic expertise with the legislation of the European Union - access mode http://dspace.nlu.edu.ua/bitstream/123456789/7223/1/Avdeeva_634.pdf

5. I.Pyrig. Classification of forensic examinations and problems of improving legislation, Kharkiv 'Pravo' 2018, p.25, access mode:

https://www.hniise.gov.ua/user files/File/sbornik/2018/\%d0\%9a\%d0\%be\%d0\%bd\%d1\%84 \%d0\%90\%d0\%ba\%d1\%82\%20\%d0\%bf\%d0\%b8\%d1\%82\%d0\%b0\%d0\%bd\%d0\%bd\%d1\%8 f\%20\%d1\%81\%d1\%83\%d0\%b4\%20\%d0\%b5_2018.pdf 
6. E.Manko. Features of forming the inner conviction of a forensic scientist (versus judge, jury and investigating judge), Kharkiv "Law" 2018, p. 48

7. V.Shepitko. Use of special knowledge in criminal proceedings: current trends and some problems, Collection - Current issues of forensic science, Kharkiv "Pravo" 2018, c.40

8. G.Prokhorov-Lukin, G. Avdeeva. Comment on the draft law of Ukraine "On Forensic Activities", 'Legal Ukraine' magazine, 1/4, p. 45, access mode:

http://dspace.nlu.edu.ua/bitstream/123456789/10348/1/Avdeeva_Prohorov-Lukin_37-62.pdf

9. G.Avdeeva. Forensic examinations: reality or myth? Kryminalist pershodrukovany. 2016. \#13. Pp. 75-78.

12. V.Shepitko. Use of special knowledge in criminal proceedings: current trends and some problems, Collection - Current issues of forensic science, Kharkiv "Pravo" 2018, p. 66

11. Forensic examination: old changes, new consequences - access mode: https://yur-gazeta.com/golovna/sudova-ekspertiza-stari-zmini-novi-naslidki.html

12. V.Shepitko. Use of special knowledge in criminal proceedings: current trends and some problems, Collection - Current issues of forensic science, Kharkiv "Pravo" 2018, p. 65

13. M.Zagryadskaya. Cryptocurrencies in Ukraine, access mode:: https://yurgazeta.com/publications/practice/podatkova-praktika/kriptovalyuti-v-ukrayini.html

14. A.Rebenko. Cryptocurrencies and forensic activities: points of contact, immediate prospects. Collection - Current issues of forensic science, Kharkiv, Pravo Pulishing House 2018, p.40 


\title{
The Concept of Distributivity In Old High German and Middle High German Texts
}

\author{
Galyna Iarmolovych \\ PhD student, German department, \\ Faculty of Romance and Germanic Philology \\ Odessa National I.I.Mechnikov University \\ Odessa, Ukraine
}

\begin{abstract}
Quantification and numbers, numerals and number words have been in the focus of research on different levels of linguistical studies. The mathematical thinking and understanding of primitive arithmetical manipulations have been covered from both the mathematical and psychological points of view. The concept of distribution developed from the ability to group objects and belongs to the second wave of the mathematical understanding of primitive people. Being one of the first concepts developed in the human consciousness it stayed un-nominalised until the development of the number consequence paradigm. The distributive constructs existing in the Modern German language are a result of development from the Proto Indo European through the Proto Germanic, Old High German, and Middle High German languages. However, the modern standard concept of distributivity is built on the preceding word - i.e., a number of colloquial variations keep being used in some German dialects.
\end{abstract}

Keywords: distributive numerals, German language history, numeral, number, linguosynergetics, selforganising systems

Quantification, numbers, and numerals as the foundational entities of mathematical thinking have raised interest among scientists in a wide range of disciplines. They have been and keep being studied from the philosophical, ethnolinguistical, historical, linguistical, anthropological, and psychological points of view. In this article the focus is on the concept of distribution, grouping and a subsection of numerals - the distributive numerals. The exemplary material used in this article, was found in the epics written in the Old High German and Middle High German languages and dictionaries of the corresponding languages.

A ,methodological revolt" - is believed to have happened in the past twenty years in language related fields of research. The focus of scientists around the world has moved from „what?“ to „how?“ and „why?“. The insatiable striving for the systematising of isolated knowledge, description, and explanation is connected to the dominant image of static and invariable systems. The appearance and development of this scientific doctrine is easy to explain: the chaotic uninterrupted stream of events/phenomena, their permanent shift and change, their evolution and diffusivity - this all demands a set of more or less steady descriptive tools. Static systems allow one to organize a variety of phenomena and to make them easier to 
observe, to perceive, and to research. Hence the static method has served linguistics well - it has created a clear, transparent system organized in a hierarchical order.

Unfortunately, the disadvantages of such a system are also well known: its passion for organizing leads to the gradual idealization and thus to the generalization of the concepts, causing the simplification of the object under study, i.e. language itself. While studying language as a dynamic system, including all its chaotic phenomena, we deal with the general problem of reality`s structure, with the possibility of revealing universal laws, by which natural and artificial language systems function. Linguists German and Pishchalnikowa support this belief „Various and multi -aspectual text studies have shown, from the psycholinguistics point of view, in the past 10-15 years, that the language is no linear sequence of language elements, but rather a complex hierarchically organized exponent of a certain nonlinear notional/conceptual entity“ $[1,11]$. The science of linguistics should equally study the isolated phenomena, the mechanisms of natural speech and the cognitive structures that an individual's intellectual activity rests upon.

Observing events and facts from the synergetics` point of view has brought humanities closer to such disparate subjects as physics and mathematics. Thus, numerous notions and terms are being effectively applied to the objects of linguistic research. The main goal of synergetics phrased by the editors of the Synergetics`Volume in the Encyclopedia of Complexity and System Science is " ... the search for unifying principles for systems that are composed of many individual parts or components, and that may show the phenomenon of self-organization, i.e., the spontaneous formation of spatial, temporal, spatial-temporal or functional structures" $[2,6]$. The main point that linguosynergetics brings into focus in language research is that "the unity itself represents a different, independent substance, than the elements composing it, and thus the laws of building a system are substantially different from the laws of syntagmatics and paradigmatics of separate elements" $[1,12]$. It is typical for linguosynergetics to draw attention to systematic ideas and their implementation into cognition and speech-producing modelling activities [3, 232]. Keywords strongly connected with synergetics - „Attractors, chaos, bifurcations and possibly catastrophes are rigorously defined mathematical terms that can only be used metaphorically when talking about language." [4, 3] However the primary ones remain intact - its all about chance events and fluctuations. The ground ideas of synergetics are openness, nonlinear nature, dynamicity of the system. These principles, when applied to 
language research reveal new knowledge about meaning-making, the functioning of communicative processes and language training methods.

Diachronic research has a special place in linguosynergetics research. Since the selforganizing language systems are inherently dynamic, this method can be shown to be especially effective in investigating the origins of language. The works of Nettle, Livingstone, Ehala, and Hurford attempt to explain the existing language diversity and its roots, as the evolution of a single language. The questions in focus could not be answered, when investigating only from a single individual's point of view. A successful project would need a complex approach from the perspective of a language as a self-organising system with the aid of structure models and computer simulations. The most relevant subfields in linguistics are: phonological systems, the emergence of grammar, word adoption and the development of concepts. Unfortunately the lack of computer literacy among linguists prevents them from expanding computer simulations, but there is a clear point of contact with yet another remote field of knowledge.

Another difficulty on the way of a linguist researching in the field of diachronic linguosynergetics is the study material itself. Studying a language system diachronically is, basically, studying phenomena between language stages remote from each other in time (synchronic language systems) by comparing and analysing them. What distinguishes it from language history is that it focuses rather on the critical stages and the evolutionary processes that surely exist in the void between the already described synchronic reflexes of a language. The existence of only written artifacts, the fragmentary nature of the preserved material, and its thematical, dialectal, stylistic and social diversity make it hard to conduct a clean, adequate experiment. Hence, T.I.Dombrovan, sees the Bible (its asynchronical text versions) as the common point of comparison for analysing diachronic change in language structure. [5, 29] Highly equal with respect to context they perfectly illustrate the structural change, that has happened in the textual corpus.

The perception and understanding of a number by humans is one of the primary proofs of mental development. Numerous archaeological findings denote that counting and quantifiers appeared before the invention of writing. Such proofs have appeared all around the world and are present in various forms. Most often these are knots, bones, bundles, dots, cuts, stones, sticks, mussels and other objects easily found in nature. For example, a young wolf s bone, found on the territory of the modern Czech Republic in 1937, is covered in cuts of different 
length which are grouped in a certain way. [6, 9]. The analysis of these cuts and their grouping leads to the conclusion that the counting existed in this territory in the prewriting period and calls into question the widespread belief, rooted in Jakob Grimm`s theory, that it developed from the observation of the hand, fingers and fists.

A similar conclusion was made by the ethnographers working on the findings in the cave Drachenloch 2,5 kilometres up in the Alps [7, 141]. This proves the central role of bear caves in the rituals of primitive people. Stoliar describes the findings as highly systematised structures used for bear-bone storing. A part of the whole cave was separated from the rest with six stone boxes filled with a certain amount of skulls, femurs, tibia and other bigger bear`s bones. The totemic meaning of bears to the primitive people is undeniable, but another conclusion made by Stoliar is that the grouping of objects and the systematisation (circle and cross) point to an already developed understanding of distribution. This kind of grouping and distribution presumably served the purpose of keeping track of the amount of animals defeated by each warrior, defining the winner and attempting to amplify their strength. Very similar conclusions were made in other caves with a comparable distribution of objects (Baverian Petershalle, Austrian Salzofen and French Kluni) [8, 100; 7, 144].

One of the earlier methods of keeping accounting records were the so-called tally sticks. They were used on most territories that carry the burden of having a standard number system because of their primitive functioning, but they are often hard to decode due to their local usage. For example, the Han dynasty w wooden sticks with inscriptions are believed to be an intermediate stage between typical tally sticks and written numerals. This method of preserving information set roots so deep into the minds of people, that even now the Chinese write their characters vertically. The word for book in the Chinese language is a bundle of sticks Before the officiation of the Han sticks different provinces used different kinds of symbols to create a functioning accounting system, but with Han sticks it became easier to account for purchases and usage of resources. This simplification led to the appearance of distributive symbols leading to even greater simplification. $[9,168]$ It should be also mentioned, that even after the actual nominalisation of numerals and spread of Latin and Arabic number symbols this primitive method of counting was often used by illiterate people to handle business up to the beginning of the 19-th century $[8,101]$. 
Another primitive but not linear way of denoting distribution without writing are the knots. In this case the different types of knots/different colours/different materials were used to identify different numerals and the usage of several rows of knots was responsible for the multiplication of the previous rows. The knot-numerals existed for "strategic" base numbers, such as $1,2,5,10,20[9,176]$

The concept of distribution has a long history in morphological and syntactical studies, but the term "distributive numeral" was first introduced into linguistics in the dissertation of David Gil in 1982 [10]. In his thorough work he outlines the morphology, syntax and semantics bringing up examples from the Tagalog, Maricopa, Georgian, English, and German languages. He has consistently elaborated on this topic further, having finally created a page/chapter on distributive numerals on WALS (the World Atlas of Language Structures online) [11]. The page he developed maps the way distributive numerals are formed, covering a total of 251 languages and dialects. The information given on the map is a cumulative gathering of research from scientists all over the world.

The possible categories are:

- no distributive numeral at all: 62 (the languages of this category still display the concept of distributivity, they just use paraphrasing of different kind)

- marked by reduplication: 85 (this category is believed to be the oldest, most primitive one, and to have been the way numerals, at least some of them, appeared in the first place)

- $\quad$ marked by prefix: 23

- $\quad$ marked by suffix: 32

- $\quad$ marked by preceding word: 21

- $\quad$ marked by following word: 5

- marked by mixed or other strategies: 23

While covering Germanic languages, David Gil refers to a particularly interesting pattern displayed in Dutch, Yiddish and German [11]. On the map he separates 3 types of Yiddish (Bessarabian, Lithuanian and Polish) - with all mark distribution preceding word, 4 types of Dutch (standard, Brabantic, Limburg and Seeuws) - with no distributive numerals and 15 types of German. The latter covers dialects of Germany, Austria and Switzerland - which, 
unlike the standard language (where distribution is formed with the preceding " $\mathrm{je}$ "), is shifting between `no distributive numerals` and the ones 'formed with the help of a preceding word`. The German (Bavarian, Mansfeldish, Westfalian, Thuringian, Hannover, Berlin, Ripuarian) and Austrian (Upper Austrian) colloquial dialects resemble their Western counterparts in having no distributive numeral construction. Zurich, Thurgau, Ostschweiz, Bern, Appenzell - the Swiss dialects display a colloquial usage of the "je" construct. Further movement to the East brings other words into the equation of distributivity. For example, the Timisoara dialect uses "jeder" and the Lodz version of Yiddish preserves the inherited from the Middle High German "zu". Moving to the East from Lodz, one once again finds distributive numerals formed by a preceding word.

The variation of distributing structures described above leads to the immediate object of study of this article, namely the distributive constructs in Old High German and Middle High German. In the course of our research the following constructs were found:

- distribution marked by the preceding word;

- distribution marked by the following word;

- distribution marked by suffixation;

- distribution marked by mixed or other strategies;

The construct of $j e+$ cardinal numeral stem, which is common in modern German, is present in the form of $i e+$ cardinal numeral stem:

dô nam si aber Esêalt

und huop ir ie zwêne mit gewalt

über der bürge zinne.

Lanzelet, 7615 [12]

Bi handen si sich viengen, ie zwo und zwo neben ein ander giengen.

Rabenschlacht, 140 [13]

It is also present in the combination of $z e, z u$, zuo sometimes connected with the following cardinal numeral stem in a proclitical junction (both - separated and unified versions can be found in the same text): 
Owe, do nam er Schemmingen

(do nam er schemingen $P$.)

ze beiden sporn, do liez er dar chlingen.

Rabenschlacht 393 [13]

Distribution marked by the following word appears in three variations - a numeral sequence with the stem falt (see table 1), cardinal numerals, with the stem mal (counting bases are prominent here) (see table 2), and a rare example used exclusively with the thousand with the stem stunt.

der dinge ist tûsent stunt mê,

diu lânt dir selten werden wê;

Die Klage, 687 [14]

Table 1

\begin{tabular}{|l|l|l|l|l|}
\hline & $\begin{array}{l}\text { Proto } \\
\text { Germanic }\end{array}$ & Old High German & Modern German & Modern English \\
\hline $\mathbf{2}$ & *twifaldaz & zwifalt & zweifach & twofold \\
\hline $\mathbf{3}$ & prī + -feald. & drifalt & dreifach & threefold \\
\hline $\mathbf{4}$ & *fepurfalpaz & & vierfach & fourfold \\
\hline $\mathbf{5}$ & fïf + -feald. & fiffalt & fünffach & fivefold \\
\hline$\sim$ & -faldaz-falpaz & gimanagfalton & mehrfach & manifold \\
\hline
\end{tabular}

Table 2

\begin{tabular}{|l|l|l|l|}
\hline & Middle High German & Modern German & Modern English \\
\hline 1 & Einmâl & einmal & once \\
\hline 2 & ze-mâle & zweimal & twice \\
\hline 100 & hant-mælec, hant-mâl, hunt-mâl & hundert mal & hunded times \\
\hline 1000 & dôzemale & tausend mal & thousand times \\
\hline$X$ & un-mælic & kein mal & no time (never) \\
\hline
\end{tabular}


Distribution marked by suffixation was found in the following two cases: zwiro, driror. The last example found in the Rabenschlacht is distribution marked by a pluractional verb in one manuscript and by a preposition+noun structure in the other: wider seiten - each side:

$N u$ wert iuch, wichrozzen! nu wert uch vast ir recken $P$.

Uns bestent di chuenen widersazzen.

vns besten die kunen wider seiten $P$.

Rabenschlacht 835 [13]

The latter example demands a deeper explanation of the correlation of distributive numerals with the pluractional verbs. In the Duden dictionary the distributive number word can be found under the name of „Distributivum“ with a link to „Verteilungszahlwort“ and „Distributivzahl“ as synonyms - Numerale, das die Einteilung in untereinander gleiche Mengen bezeichnet; Verteilungszahlwort, Einteilungszahl (im Deutschen durch ,je“ wiedergegeben; z. B. ,je drei“c) [15]. A numeral that describes the division into equal quantities (Author`s translation). The function given by this description does not cover the whole concept of distributivity. The latest cross-semantic approaches describe its function as "plurality of events or individuals distributed with respect to another plurality" [16, 1] The difference between the two is that distributive numerals modify noun phrases to indicate a plurality of individuals while the pluractional morphemes modify verb phrases to indicate a plurality of events. Which means that they pertain to different syntactic categories and different semantic domains. Distributive numerals and pluractional verbs also share important compositional properties. First of all, the plurality of actions or events is described relative to another plurality referred to in context. They both act as a plurality filter and put restrictions on what may serve as a distributive key $[16,17]$. In this case the verb widerscezzen does not belong to the domain of pluractional verbs because it does not indicate the plurality of events, though it definitely indicates the opposition, thus setting a plurality filter on the amount referred to.

\section{Conclusions}

Despite certain weaknesses (non-ideal research material, lack of computational literacy) diachronical linguosynergetics complements the traditional language history research with a new perspective - studying the language as a dessipative system using new, cognitive instruments. 
The concept of distribution has developed from the grouping of objects which has developed from the need to process bigger numbers, which in its turn has developed from the primitive human ability to distinguish few from many, which is a direct result of evolution. Thus, the concept of distribution existed longer than many other quantification concepts and arithmetical operations. Nevertheless, the actual nominalisation of this group of quantifiers happened after the appearance of cardinal and ordinal numerals and is based on the usage of their stems. Its verbal realisation differs from language to language and can be grouped by the way it is marked into seven main groups.

In Old-High German as in Middle High German the concept of distributivity is formed in four ways: on a proclitic pronoun-noun bond of $z e-, z u-z u o$ - and the numerals`stem; through the suffixation $-r-$ - -ir-, -ro-; through the addition of a preceding word, $i e$; through the addition of the following words/stems: falt, mâl, stunt. The material researched for this article gave another example a contextual distribution of wider, which works only for opposing entities in one manuscript and a verb widerscezzen representing distributive plurality in the other.

The stems used in the formation of the distributive numerals are mostly the ones believed to be "bases of counting". They were at first unstable and conditioned by the local needs, later they gradually developed into stable ones, one, two, five, ten, hundred, dozen, following the laws of linguosinergetics (naturally developing ecosystems of languages).

The concept of distributivity has lately come into light, due to the numerous studies that were done on this topic, but it remains understudied in some aspects.

\section{References}

1. German I. A. Pishchalnikova V. A., 1999. Linguosynergetics. Barnaul: Altai National University. Pp.110.

2. Hutt A. Haken H., 2020. Synergetics. (Encyclopedia of Complexity and Systems Science). Stuttgart: Springer. Pp. 455.

3. Ismailova O. I., 2018. The Peculiarities of Linguistic Synergetics. Synergy of science. №25. - p. 881-884.

4. de Boer B., 2009. Self-organisation in language. Cambridge University Press. [online] Available at: https://www.cambridge.org/core/books/selforganisation-and-evolutionof-biological-and-social-systems/selforganisation-inlanguage/19F8A15FFC0A82A179F6B115BE2E3BEB.

5. Dombrovan T. I., 2014. Diachronic linguosynergetics as a new approach to the studies of language development. Writings in Romance-Germanic Philology. №2. p. 24-32. 
6. Resnikoff, H. and Wells, R., 1984. Mathematics in civilisation. New York: Dover.

7. Stoliar A.D. 1971 Natural art of neanderthals as the basis of genesis. Natural Art. Novosibirsk. p. 118-164.

8. Rybakov B.A. 1994. The paganism of the old slavs. Moscow: Nauka.

9. Menninger, K. 2013. Number Words and Number Symbols. New York: Dover Publications.

10. Gil, D., 1982. Distributive numerals. Los Angeles: University of California, Los Angeles dissertation.

11. Gil, D., 2021. WALS Online - Chapter Distributive Numerals. [online] Wals.info. Available at: <https://wals.info/chapter/54> [Accessed 2 March 2021].

12. Kragl, F. and Ulrich, 2006. Lanzelet. Berlin: Walter de Gruyter.

13. Lienert, E. and Wolter, D., 2005. Rabenschlacht. Tübingen: Max-Niemeyer Verlag.

14. von Aue, H. and Gärtner, K., 2015. Die Klage. Berlin/München/Boston: De Gruyter.

15. Duden. 2021. Verteilungszahlwort. [online] Available at: <https://www.duden.de/rechtschreibung/Verteilungszahlwort> [Accessed 3 March 2021].

16. Kuhn, J., 2019. Pluractionality and distributive numerals. Language and Linguistics Compass, 13(2), p.e12309. 


\title{
Communicative Taboos in Modern Business Etiquette
}

\author{
Kanyukova Irina Yanovna, \\ Candidate of Pedagogical Sciences, Associate Professor of the Department \\ of Philosophy and Pedagogy, Kiev National University of Culture and Arts, \\ Kiev, Ukraine,
}

\author{
Sidorovskaya Evgeniya Andreevna, \\ Candidate of Cultural Studies, Senior Lecturer of the Department \\ of Philosophy and Pedagogy, Kiev National University of Culture and Arts, \\ Kiev, Ukraine
}

\begin{abstract}
The article examines the features of communicative taboos in business etiquette.
The taboo system has protected core values for centuries and has been an unwritten social code. Taboo reflects the foundations of morality, spiritual culture, features of thinking and worldview of individuals and ethnocultural communities. The spheres and nature of taboos are a reflection of the times and cultures of the people and are clearly manifested in the process of intercultural communication. Violation of the most severe taboos can lead to termination of contact.

The study found that in the process of intercultural communication, given the similarity of most taboo topics, the degree of categoricalness of their use is different, or the circumstances under which certain topics can be raised are different.

In order to comply with the verbal rules of business etiquette valid in one's own or in other cultures and ethnic groups and at the same time ideologically express the necessary meaning, promoting friendly intercultural communication, it is necessary to use a number of ways not to break taboos related to language units. etc. In the case of nonverbal taboos, mutual misunderstanding and non-perception in the process of nonverbal communication usually occurs because a somatic object is used to nonverbally express a certain meaning or perform a certain movement, which cannot be used from the point of view of another culture.
\end{abstract}

Key words: verbal taboos, nonverbal taboos, intercultural communication, business etiquette, taboo topics

Актуальність дослідження. Однією з характерних особливостей міжкультурної комунікації - особливої форми комунікації двох або більше представників різних культур, етносів, процес якої представлений обміном інформації та культурними цінностями взаємодіючих культур, що відображає іiі нормативну природу, є широке поширення різноманітних соціальних обмежень, заборон, які штучно звужують сферу спілкування окремих індивідів та їх груп. Особливе місце займають вони в діловому етикеті - сукупності правил та норм, визнаних загальноприйнятими в діловій сфері та міжнародному економічному співробітництві. 
Зважаючи на посилення загальносвітової відкритості та взаємозалежності країн, регіонів, підприємств та співтовариств - глобалізаційних процесів, актуальним $є$ дослідження проблематики табу в рамках ділового етикету в контексті особливостей міжкультурної комунікації.

Аналіз публікацій. Взаємодія культур на сучасному етапі розвитку наукової думки розглядається у складному динамічному контексті - процеси модернізації в усіх галузях життєдіяльності людини являють собою складний багаторівневий синтез різних підсистем, маркованих відповідними акцентами у системі ціннісних переваг.

Особливу увагу науковців у контексті глобалізаційних процесів привертає питання впливу на сучасну культуру спілкування, взаємодію людей під час міжкультурної комунікації. Серед вітчизняних дослідників окремі аспекти міжнародного ділового етикету висвітлено у наукових публікаціях та розвідках Н. Ботвіна, О. Брух, Н. Завальницької, Ю. Словської, М. Лукачевич, В. Малахова, І. Осечинського, Ю. Палеха, Л. Ручко, В. Снітинського, М. Стахова, С. Цвілюк, С. Федько, I. Хожило, Г. Чайки та ін.

Вивчення феномену «табу» - елемента ділового етикету, тактичної складової культурної компетенції, що передбачає вміння розпізнавати ціннісні установки, ознаки психологічної та соціальної ідентичності, характерні для окремої культури, дозволяє виділити «проблемні» сфери та діагностувати стан духовності суспільств.

Мета статті - виявити особливості комунікативних табу в рамках ділового етикету.

Виклад основного матеріалу. Важливою складовою діалогу культур є знання та дотримання національних культурно-специфічних особливостей. Зазвичай комунікатори спілкуються відповідно до власних національних норм комунікативної поведінки, що, як правило, не повністю відповідають нормам іноземного партнера.

В міжкультурній комунікації табу займають особливе місце, оскільки непорозуміння, що викликані порушенням табу є найбільш відчутними.

Табу - багатопланове явище мови та культури, що включає лінгвокогнітивний, соціокультурний, психологічний, психолінгвістичний, прагмалінгвістичний та лінгвістичний аспекти. 
Термін «табу», що належить до міждисциплінарної термінології і широко використовується в антропології, етнології, соціології, культурології та інших науках має полінезійське походження. Відомий антрополог Т. Норскот стверджує, що табу включає в себе священну (або навпаки, нечисту) ознаку осіб або речей; рід обмежень, заборон, що витікають з цієї ознаки та святість (або пї протилежність - нечистість), що відбувається внаслідок порушення цих заборон [7].

Табу означає заборону, що виникає в сфері суспільного життя на різних рівнях людського розвитку. Початково поняття табу, що з'явилося у багатьох народів на основі міфологічних вірувань [5, с. 104], використовувалося лише для означення особливого роду заборон на певні дії. Проте якщо будь-яке поведінкове табу є забороною, то не будьяка норма поведінки, що забороняє певні дії $\epsilon$ табу, оскільки табу $є$ забороною особливого роду.

Незважаючи на відмінність давнього і сучасного розуміння табу - якщо у первісної людини при дотриманні табу на першому місці стояли страх перед демонічними силами, забобони та упередження, то нині людиною керують такі емоційно-модальні стани як сором, скромність, дотримання заповідей, небажання образити кого-небуть - сенс та детермінуючі ознаки табу лишаються незмінними, а саме, психологічний, соціальний та релігійний фактори його виникнення.

Зі змінами культурних умов сфера використання табу також трансформується, оскільки відкидаючи табу попередніх історичних етапів, сучасне суспільство створює нові табу, а деякі теми табуювання лишаються незмінними.

Термін «табу» на сучасному етапі розвитку суспільства означає порушення правил порядності або етикету.

Вітчизняна дослідниця Ю. Словська, визначає табу як «жорстку заборону або ситуативне обмеження на вживання в мовленні певних мовних одиниць (звуків, букв, лексем, словосполучень тощо), несегментних фонетичних одиниць (тону, висоти голосу, тембру, інтонації тощо), тем, а також уникання спілкування з окремими особами, зумовленого різними екстралінгвістичними чинниками (релігійно-магічними, суспільнополітичними, культурними, морально-етичними тощо» [2, с. 49].

Дослідники наголошують на трьох основних компонентах табу:

- глибока впевненість людей, які належать до певного колективу; 
- відчуття страху перед невідомою небезпекою;

- заборона як норма життя [9, с. 258].

Е. Ліч стверджує, що табу можна віднести до культурних універсальній [4, с. 46]. Оскільки раніше багато явищ та подій здавалися людям незрозумілими, викликаючи відповідно страх та побоювання, вони ухилялися від вимовляння назви певного феномену або предмету - так з'явилися заборонені або табуйовані слова. У багатьох культурах є заборона на вживання назв певних предметів та явищ. Наприклад, імен богів, духів та демонів, смерті, хвороб, тварин, сонця, вогню, місяця та частин людського тіла.

Зазвичай табу поширюється на поводження з культово-значущими предметами $\mathrm{i}$ особами - релігійній забороні у первісних народів підлягали певні дії з метою уникнення ворожих проявів надприродних сил, окрім того існувала заборона на вживання певних слів, зумовлена соціально-політичними, історичними, культурними, етичними та емоційними факторами.

Наприклад, у китайській культурі типовим є табу на вимову або написання імен пращурів та імператорів - у Китаї з давніх давен вважалося актом прояву глибокої неповаги вимовити ім'я поважної та старшої людини, особливо імператора та власного батька.

У даному дослідженні поняття табу розуміємо як соиіально та культурно зумовлена заборона вимовляти ті або інші слова та вирази, а також заборона здійснювати певні регламентовані культурою та суспільством дії.

На думку дослідників, зазвичай табу викликані невідповідністю між біологічним станом людини та його біологічними характеристиками з одного боку і культурним або соціальним статусами людини, з іншого. Вони виникають внаслідок протиріччя між відносною свободою тілесної, мовної, акціональної та іншої поведінки людини та регламентаціями, що накладаються на іiі поведінку соціальним колективом або культурою [3, с. 6].

Комунікативні табу в контексті специфіки ділового етикету можемо типологізувати наступним чином:

- вербальні табу: заборона на використання грубих або нецензурних виразів, а також недоречних у тій чи іншій комунікативній ситуації мовних формул, що використовуються без урахування статусно-рольових стосунків між комунікантами; 
- невербальні табу (заборона конкретної жестикулящії, міміки, поз): заборона використання окремих компонентів невербальної поведінки під час спілкування (наприклад, не можна відвертатися від співрозмовника, пильно дивитися в очі, сильно жестикулювати, багаторазово торкатися до співрозмовника, голосно розмовляти, говорити швидко, тримати руки в кишенях тощо);

- тематичні табу: заборона обговорення певних тем, що вважаються принципово конфліктними та етично недоречними (табуйовані теми є динамічним, соціально залежним поняттям, оскільки в умовах внутрішньокультурної комунікації певні теми можуть припинити вважатися табу, а інші - навпаки табуюватися).

На думку дослідників, саме недотримання тематичних табу $\epsilon$ найбільш небезпечним для комунікативних взаємодій, оскільки це може викликати непередбачувану емоційну реакцію або суспільний докір [9, с. 239].

Хоча існують й інші типологізації. Наприклад, Г. Крейдлін розрізняє вербальні, невербальні та змімані, або вербально-невербальні комунікативні табу. До останнього типу дослідник відносить заборону вимовляти певні слова і одночасно виконувати ті чи інші знакові дії в актах комунікації [3, с. 6]. На думку науковця, у кожній галузі функціонування табу доцільно виділити такі відгалуження, як контекстно (ситуативно) незалежну та контекстно (ситуативно) зумовлену.

Поняття табуйованості знаходиться в морально-етичній площині суспільної свідомості, відповідно у зв'язку з цим класифікація тем на припустимі і неприпустимі також має морально-етичний характер, що сформувався під впливом суспільної думки за принципом комунікативної доречності або недоречності.

Серед основних сфер функціонування вербальних табу виділяється релігія, моральна сфера та політика, а також суспільна та міжособистісна поведінка людей, ритуальна та церемоніальна галузь (в середині кожної виокремлюють особливо табуйовані теми та предмети).

Так, наприклад, найпоширенішими тематичними табу для європейців є:

- обговорення теми смерті;

- обговорення інтимних стосунків;

- обговорення расової, національної, гендерної, релігійної приналежності; 
- обговорення негативних явищ дійсності (безробіття, проституція, злидні, алкоголізм, наркоманія, збройні конфлікти та ін.);

- обговорення захворювань; обговорення дискусійних тем з точки зору моралі, етики та права (аборти, сурогатне материнство, евтаназія, клонування та ін.);

- недоречні питання особистого характеру.

Окрім того, у Великобританії не прийнято обговорювати особисте життя, погані звички та захворювання, публічно говорити про фізіологічні процеси організму. Забороненими темами вважаються також питання про заробітню платню, сімейний стан та вік, тобто табуйованими $є$ такі теми, які так чи інакше могли б викликати незадоволення або непорозуміння з боку співрозмовника, призвести до суперечок або чвар.

Евфемізм як один із різновидів стилістичних засобів дозволяє співрозмовникам варіювати мови в залежності від комунікативних умов, за необхідністю приховувати або варіювати власні наміри, з метою уникнення конфліктів у спілкуванні, які можуть відбуватися у випадку прямолінійної номінації певних дій, предметів та ін., тобто у випадку порушення табу.

Табу та евфемізми підтримують відповідний культурний рівень вербального спілкування та етичні норми мовної поведінки.

Дослідники наголошують на відмінностях невербальних табу в культурах апофатичного ставлення, суть якого полягає в прагненні людини приховати тіло від сторонніх очей, зробивши його непомітним, непримітним і разом із тим, ідеальним, та культурах вільної тілесної поведінки, водночас акцентуючи на важливості контексту, оскільки невербальні знакові дії можуть бути табуйованими або нетабуйованими в залежності від значень, які вони виражають [3, с. 8].

Наприклад, підморгування табуйовано в апофатичних культурах у контексті флірту і дозволено в культурах вільної тілесної поведінки, хоча у випадку використання даного жесту як натяку на «співучасть в таємній події» дозволено в обох культурах.

Для жестових табу важливу роль відіграє розподіл, що стосуються до самих тілесних об’єктів, табуйованих у конкретній культурі у ситуації, що передбачає виконання певного жесту або певного незнакового руху. Зокрема, деякі табуйовані 
тілесні об'єкти в іншій культурі позиціонуються як повноправні компоненти фізичної реалізації жесту або руху такої ж форми.

Взаємне непорозуміння та несприйняття в процесі невербальної комунікації зазвичай виникає тому, що для невербального вираження певного сенсу або виконання певного руху використовується соматичний об'єкт, яким з точки зору іншої культури користуватися не можна.

Наприклад, у процесі спілкування з людиною мусульманської культури, а також деяких інших культур, не можна використовувати ліву руку, оскільки у них вона вважається нечистою (в культурі мусульман для всього брудного, що вимагає використання рук, треба використовувати саме ліву руку). У багатьох країнах, у тому числі на Близькому Сході, деяких частинах Індії та Африки (в тому числі Західної Африки) [6, с. 171] табуйованим є використання лівої руки для того, щоб помахати людині на знак привітання, прийняти подарунок або щось передати (навіть якщо порушується принцип фізіологічної зручності).

Відповідно до європейського етикету неприпустимо сидіти, схрестивши ноги, під час розмови з людиною тої культури, в якій ця поза осуджується.

Важливість знання та дотримання табу національних культур у процесі міжкультурного ділового спілкування не применшує важливість дотримання вербальних та невербальних табу загальноприйнятих в масштабах світового ділового етикету, до яких належить:

- табу на прояв ознаки переваги або зневаги до співрозмовника;

- табу на створення психологічних бар'єрів;

- табу на відкриту критику або приниження співрозмовника;

- табу на нетактовні дії стосовно співрозмовника (наприклад, ігнорувати, висловлювати підозри, висміювати, обривати промову та ін.) [1, с. 97];

- табу на тримання рук у кишенях, складання їх на грудях, жест вказівним пальцем та ін.

Система табу протягом століть захищала основні цінності та була неписаним соціальним кодексом. Табу відображає основи моральності, духовної культури, особливості мислення та світосприйняття окремих особистостей та етнокультурні спільноти. Сфери та характер табуювання є відображенням доби та культур народу і 
проявляються в процесі міжкультурного спілкування. Порушення найбільш жорстких табу може призвести до припинення контакту.

Висновки. Дослідження виявило, що в процесі міжкультурної комунікації за умови схожості більшості тем табу, відмінними є ступінь категоричності їх вживання, або ж відрізняються обставини за яких можуть бути підняті ті чи інші теми.

3 метою дотримання чинних у власній або в чужій культурах та етносах вербальних правил ділового етикету і водночас ідеоматичного вираження необхідного сенсу, сприяючи доброзичливому міжкультурному спілкуванню, варто використовувати ряд способів не порушувати табу, пов’язаних з мовними одиницями, зокрема синонімічні перефразування, метафоричні заміни та ін. У випадку з невербальними табу взаємне непорозуміння та несприйняття в процесі невербальної комунікації зазвичай виникає тому, що для невербального вираження певного сенсу або виконання руху використовується соматичний об'єкт, яким з точки зору іншої культури користуватися не можна.

\section{References}

1. Gritsenko, T.B., Ishchenko, T.D., Melnichuk, T.F. (2007). Kyiv: Center for Educational Literature.

2. Yelovskaya, Y. V. (2015). Implementation of taboos in business discourse (on the material of business speech of Ukrainians). Odessa Linguistic Bulletin. Issue 5 (1), pp. 48-51.

3. Kreidlin, G. E. (2018). Non-verbal taboos and mixed communicative taboos in different cultures. Izvestiya RAN. Series of Literature and Language. Vol. 77. no. 4., pp. 5-14.

4. Lich, E. (2001). Culture and communication: The logic of the relationship of symbols. On the use of structural analysis in social anthropology. Moscow: Eastern Literature.

5. Reformatskiy, A. A. (1998). Taboos and euphemisms. Introduction to linguistics. Moscow: Aspect Press.

6. Ameka, F. K., Breedweld, A. (2004). Areal cultural scripts for social interaction in West African communities. Intercultural Pragmatics, Issue 1-2.

7. Britannica. The Editors of Encyclopaedia. "Taboo". Encyclopedia Britannica. URL : https://www.britannica.com/topic/taboo-sociology. Press.

8. Kanazawa, I. (2001). Introduction to Religious Anthropology, Religious Culture

9. Wardhaugh, R. (2006). An Introduction to Sociolinguistics (Fifth edition). Oxford: Blackwell Publishers Ltd. 


\section{Translation of the References to the Author's Language}

\section{Список використаних джерел}

1. Гриценко Т.Б., Іщенко Т.Д., Мельничук Т. Ф. Київ : Центр учбової літератури, 2007. $344 \mathrm{c}$.

2. Словська Ю. В. Реалізація табу в діловому дискурсі (на матеріалі ділового мовлення українців). Одеський лінгвістичний вісник. 2015. Вип. 5(1). С. 48-51.

3. Крейдлин Г. Е. Невербальные табу и смешанные коммуникативные табу в разных культурах. Известия РАН. Серия Литературы и языка. 2018. Т. 77. № 4., С. 5-14.

4. Лич Э. Культура и коммуникация: Логика взаимосвязи символов. К использованию структурного анализа в социальной антропологии. Москва : Восточная литература, 2001. 142 с.

5. Реформатский А.А. Табу и эвфемизмы. Введение в языковедение. Москва : Аспект Пресс, 1998. 536 с.

6. Ameka F.K., Breedweld A. Areal cultural scripts for social interaction in West African communities. Intercultural Pragmatics, 1-2. 2004.

7. Britannica. The Editors of Encyclopaedia. "Taboo". Encyclopedia Britannica. URL : https://www.britannica.com/topic/taboo-sociology (дата звернення : липень 2021). $362 \mathrm{p}$.

8. Kanazawa I. Introduction to Religious Anthropology, Religious Culture Press, 2001.

9. Wardhaugh R. An Introduction to Sociolinguistics (Fifth edition). Oxford: Blackwell Publishers Ltd, 2006. 418 p. 


\title{
The Colosseum in the film «Roman Holiday» (1953)
}

\author{
Turchynova Ganna
}

Candidate of Pedagogic Sciences, Associate Professor

Dragomanov National Pedagogical University

Pet'ko Lyudmila

Candidate of Pedagogic Sciences, Associate Professor

Dragomanov National Pedagogical University

\section{Grigoruk Valeria}

Student of Faculty of Natural and Geographical Education and Ecology

Dragomanov National Pedagogical University

"While stands the Coliseum, Rome shall stand; When falls the Coliseum, Rome shall fall; And when Rome falls - the World."

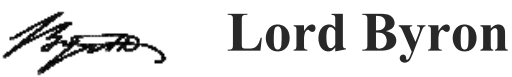

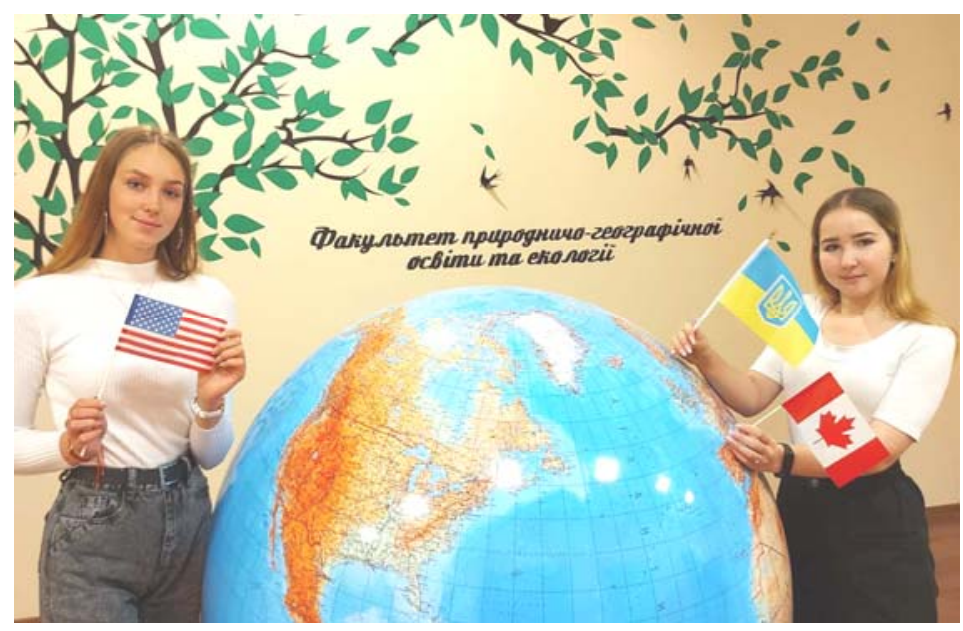

Fig. 1. Students A. Melnychuk [29] and V. Grigoruk.

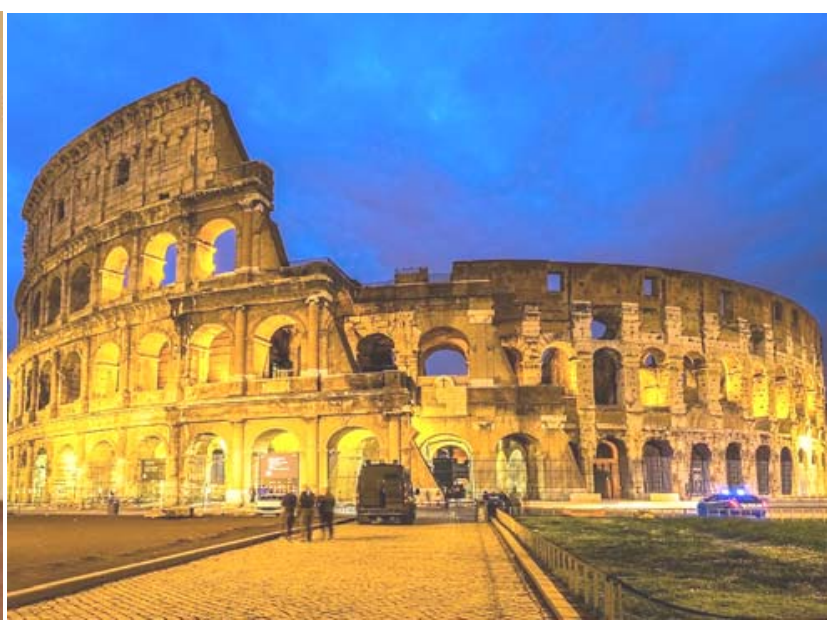

Fig. 2. The Colosseum, Rome (Italy).

\begin{abstract}
This article is dedicated to the Colosseum and a classic movie filmed in Rome "Roman Holiday" (1953, USA). It was the first Hollywood film to be filmed and processed entirely in Italy. The great thing about Rome is that not much changes in the historic city centre. The story is about princess Ann (played by Audrey Hepburn) who comes to Rome and slips out one evening from the Embassy, and an American journalist (Gregory Peck). Joe takes Ann around Rome for a "Grand Day Out" and we have loads of views of Rome, both the famous monuments and the streets, squars, and bridges. So when Audrey Hepburn surveys the Colosseum, she's really surveying the Colosseum.
\end{abstract}


In the film "Roman Holiday", Princess Ann holds on tight as they race through the roads past the famous Colosseum. The stars riding a Vespa made an iconic movie poster for the film, during an important era for Italian filmmaking.

The authors of the article offer an innovative approach to the formation of a professionally oriented foreign language learning environment by studying the filming locations of the masterpiece of world cinema "Roman Holiday" (1953, USA), on the example of the Colosseum. It is a typical example copied throughout the empire: a highly decorative exterior, seats set over a network of barrel vaults, and underground rooms below the arena floor to hide people, animals and props until they were needed in the spectacles of the"Theatre of Death".

Rememered the greatest English historian of all time Bede, Lord Byron's poem"Childe Harold's Pilgrimage", gladiators.

Key words: university, professionally oriented foreign language learning environment, students, "Roman Holiday" (1953, USA), the Colosseum, St. Bede the Venerable, "Childe Harold's Pilgrimage" by Lord Byron, gladiators.

Roman Holiday (1953, USA) is a classic movie filmed in Rome. The great thing about Rome is that not much changes in the historic city centre. We can see the same things today as tourists could in the 1950s when this movie was made (movie [34]).

Our student project group is studying the filming locations $[9 ; 12 ; 13 ; 24 ; 25$; $28 ; 29 ; 58 ; 59]$. Our paper is dedicated to the Colosseum (Fig. 1), see videos [46; 2].

With Rome as the backdrop, Audrey Hepburn's Princess Ann rendezvoused with adventure, freedom and romance in the 1953 mega flick Roman Holiday (1953).

The story is about princess Ann (played by Audrey Hepburn) who comes to Rome and slips out one evening from the Embassy, and an American journalist (Gregory Peck) who spots her lying on the bench at night but doesn't recognize her at first, takes her home and puts Ann to bed in his flat. The next morning he's discovered who she is and realizes he's got a story on his hands [55], video [37].

Joe takes Ann around Rome for a "Grand Day Out" and we have loads of views of Rome, both the famous monuments and the streets, squars, and bridges as they zip around the city on a Vesta scooter [55] (Fig. 3, 4, 5, 6).

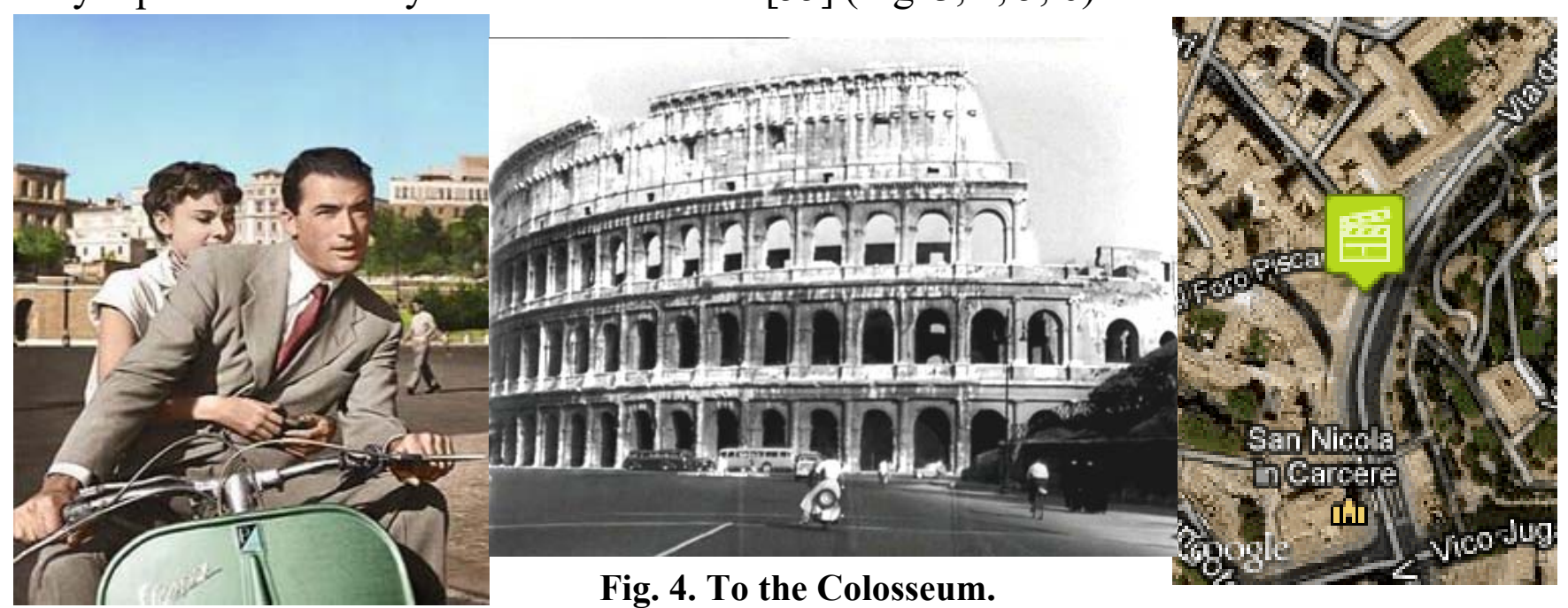

Fig. 3. On a Vesta scooter (Roman Holiday, 1953).

Fig. 5. The Colosseum on the map. 
The Colosseum can never be too far away when we're in Rome, so of course the largest amphitheatre in the world makes an appearance in the lives of our one-day lovers. Its 2,000-year-old history weaves in the glory of an invincible architecture and the violence of gladiator battles and animal hunts [42]. It's one of the symbols of Rome.

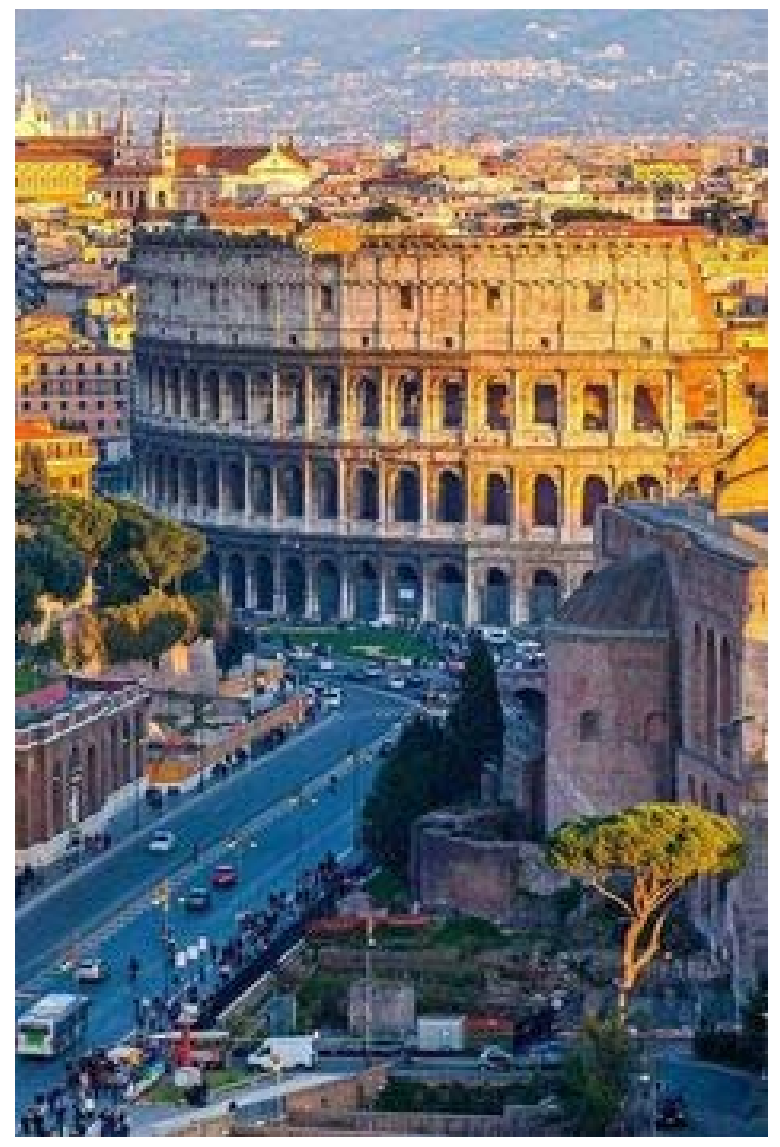

Fig. 6. Via dei Fori Imperiali and the Colosseum.

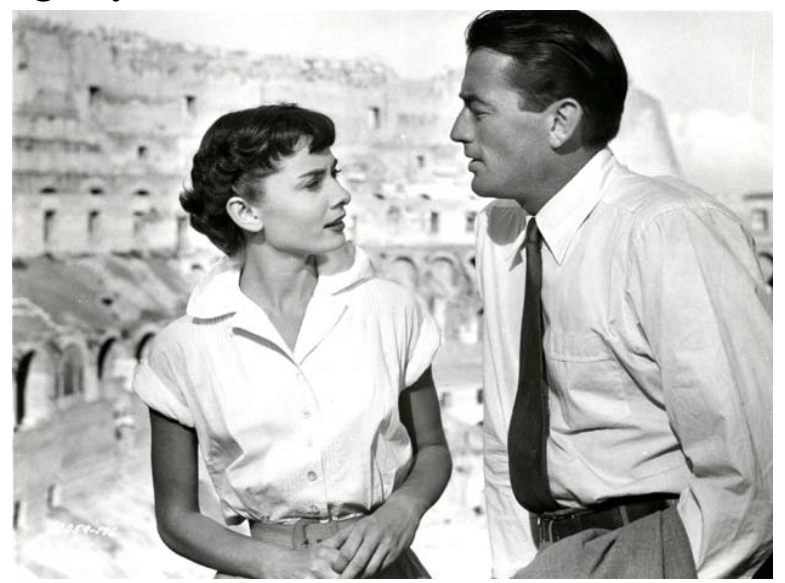

Fig. 7. Audrey Hepburn and Gregory Peck (1953).

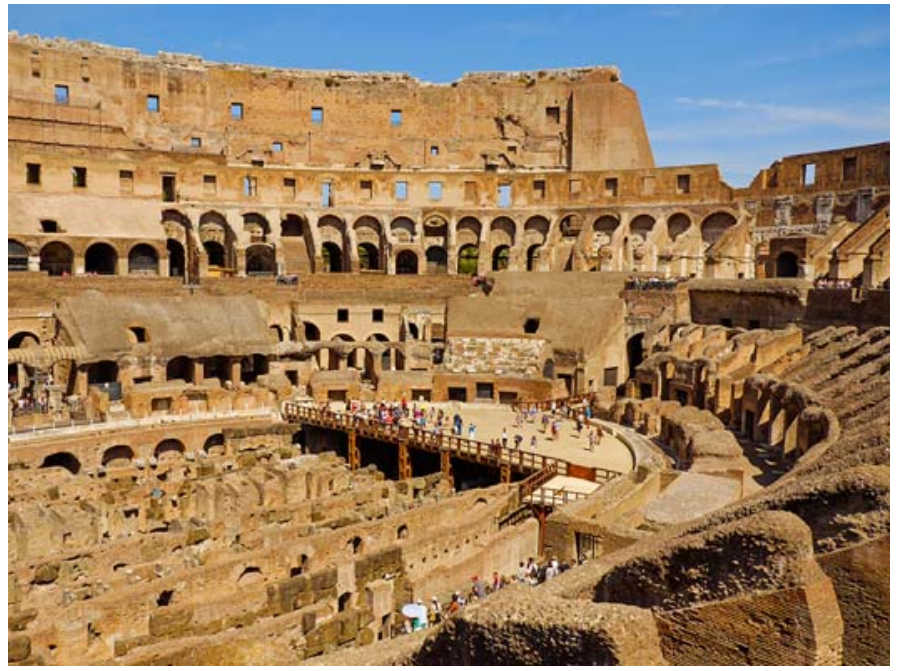

Fig. 8. Interior of the Colosseum.

At the beginning of the mentioned episode from the film Roman Holiday (1953) Irving (Fig. 9) failed to gain a strict answer to the upcoming destination of Joe and Anne (see the video [38]), yet the scene is being passed into another one on the motorbike. (And some words about Joe's friend Irving. More than just generating keepsakes, Eddie Albert also provides valuable humor to the film's already bubbly surface. We "always get a kick out of Joe spilling his drink on Irving to prevent him from spilling any beans,... also enjoy his guerrilla style of picture taking, such as driving a car while taking shots (this actually mirrors Wyler's shooting style as well) [40]).

The movie duet passes the Teatro Marcello, an ancient theater with a history of two thousand years, often misregarded as the Coliseum. This city landmark is located within easy distance to Piazza

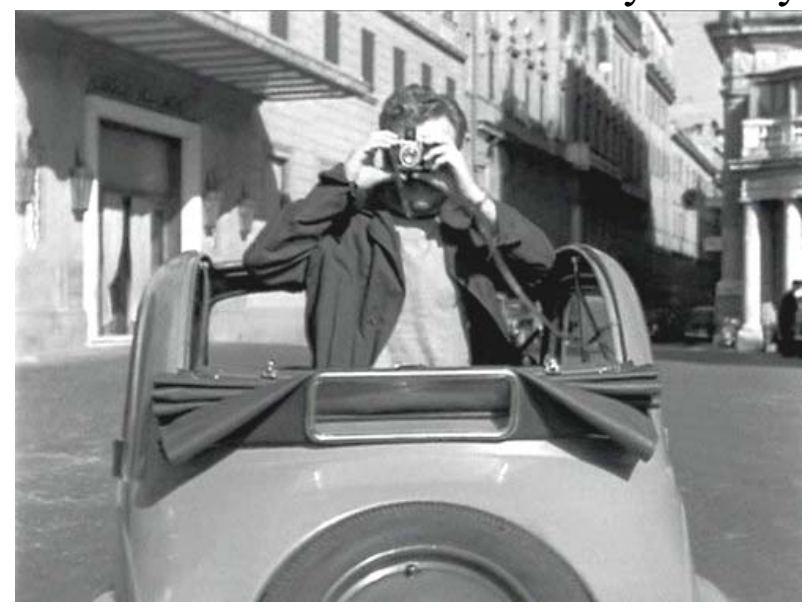

Fig. 9. Eddie Albert as Irving (Roman Holiday, 1953). 
Venezia square. The background panorama of the upcoming scenes includes a part of Vittoriano (Vittorio Emanuele II Monument) far behind (Fig. 10).

Finally, another shift of the camera interspaces the shot with a magnificent Coliseum, a world-wide recognized landmark of Rome, a reminder of the once vanished glory of the Roman Empire. The scene takes Joe and Anne from behind, all while they are moving along Via Dei Fori Imperiali (Fig. 4, 5, 6, 10) up to the

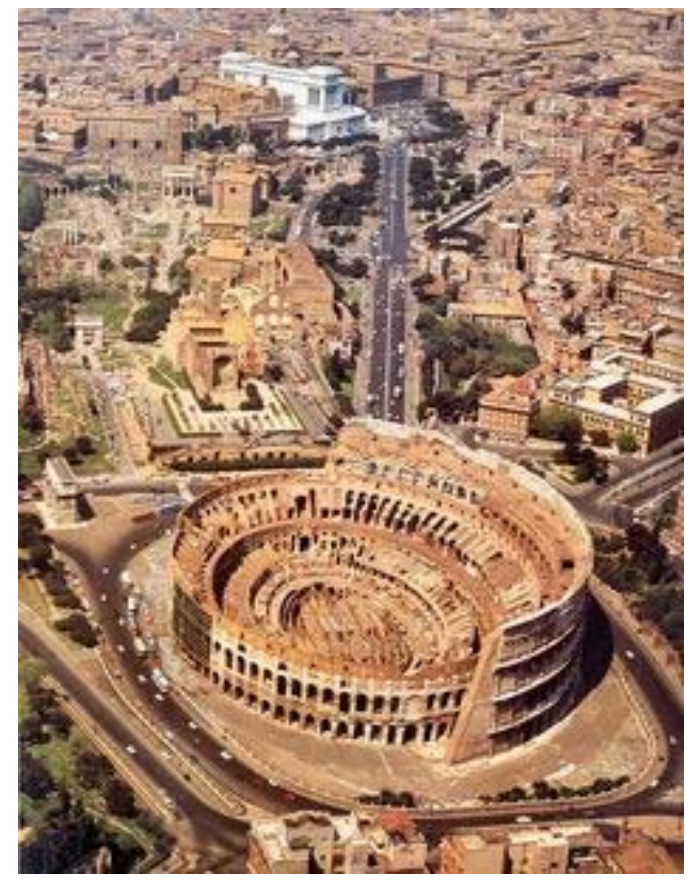

legendary arena. A movie visit to Coliseum turns out to be a source of some breathtaking panoramas with the best inner dimensions and angles of the arena, had once seats for 50000 people [4]. (Fig. 8, 10, 11), see the video [6].

The movie trio then makes a pit stop at the Colosseum. Like many of the structures in Rome the pictures we see do not do it justice, but Roman Holiday (1953) comes close to capturing its sheer immensity (Fig. 4, 6, 8, 10, 11), see the video [1].

In the days before computer-generated images, real men tore each other apart, and this is where they did it. The largest amphitheater in the world had just a few strategically placed tourists in it when a guide explained its 2,000-year

Fig. 10. Via Dei Fori Imperiali. history to Princess Ann and Joe [44]. (Fig.7,8,11, 12,13, 14). We can see a truly wonderful movie starring Gregory Peck and Andrey Hepburn. It was the first Hollywood film to be filmed and processed entirely in Italy. So when Audrey Hepburn surveys the Colosseum, she's really surveying the Colosseum [41], see the video [33].

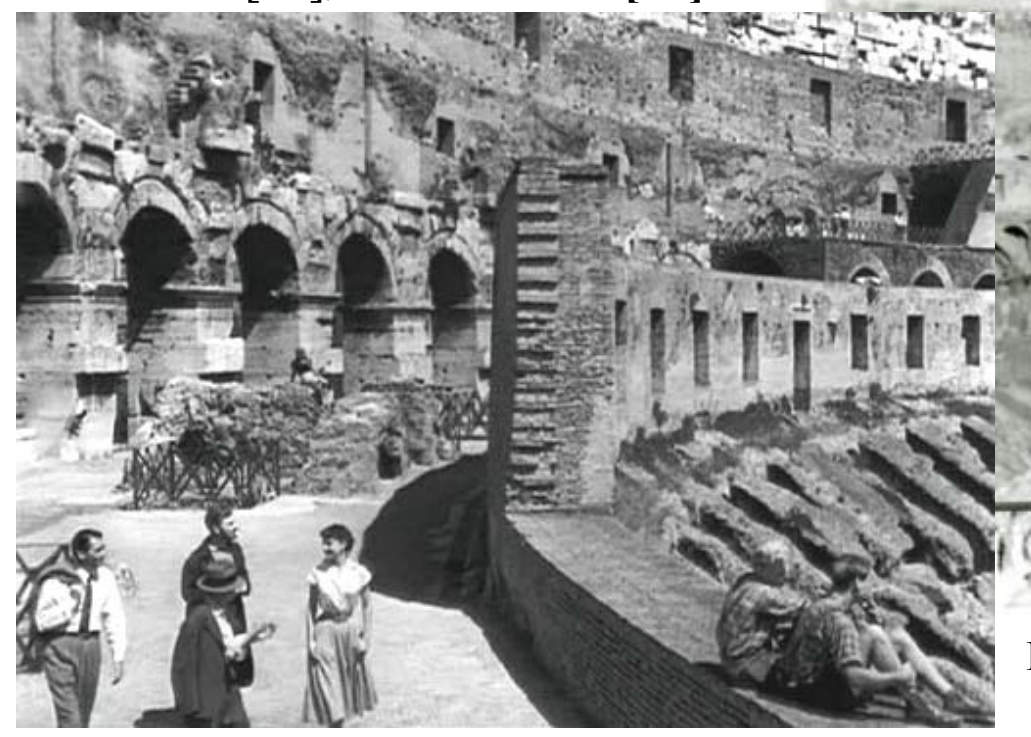

Fig. 11. Roman Holiday (1953, USA). Ann. Joe, and Irving inside the Colosseum.

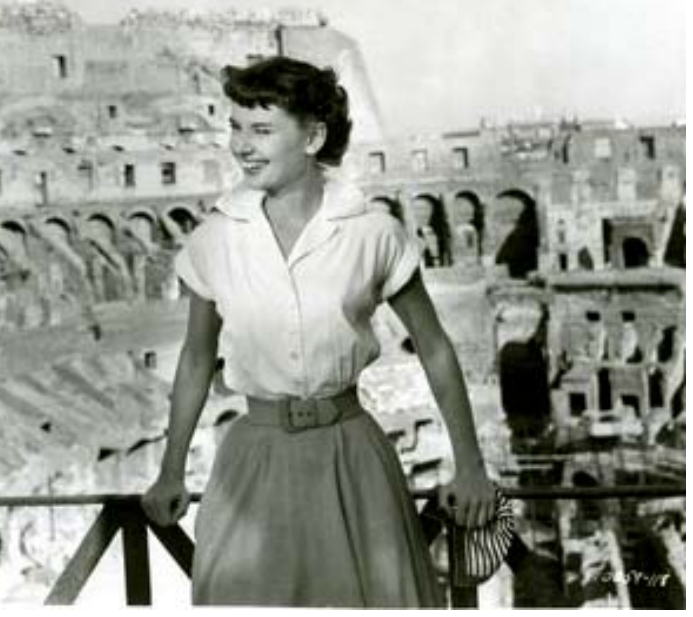

Fig. 12. A. Hepburn as Princess Anne. Roman Holiday (1953, USA).

From the script of the movie "Roman Holiday" (1953). In the city, Joe drives along the streets on a little Vespa scooter; Princess Ann riding side-saddle on the 
back, her arms wrapped around his waist (Fig. 3, 4, 32). She looks out smiling at the sights as they drive to the Colliseum, looming up before them. They walk inside the Colliseum, accompanied by a guide who points to the structure, instructing Ann (Fig. 9, 11, 14). Joe follows just behind them, being joined now by Irving (Fig. 14). They walk to the edge, looking down over the centre of the structure. Ann listens to guide, watched on by Joe and Irving who lights up a cigarette. Holding the lighter,Irving signals secretly to Joe who acknowledges him with a private signal of his own. Back on the streets of Rome and Joe and Ann ride along on the scooter, followed by Irving in a small open-topped car. Irving overtakes them and, as Joe points out the sights to Ann, he takes pictures out of the back of the vehicle, barely regaining control of the vehicle afterwards [39], see the video [45].
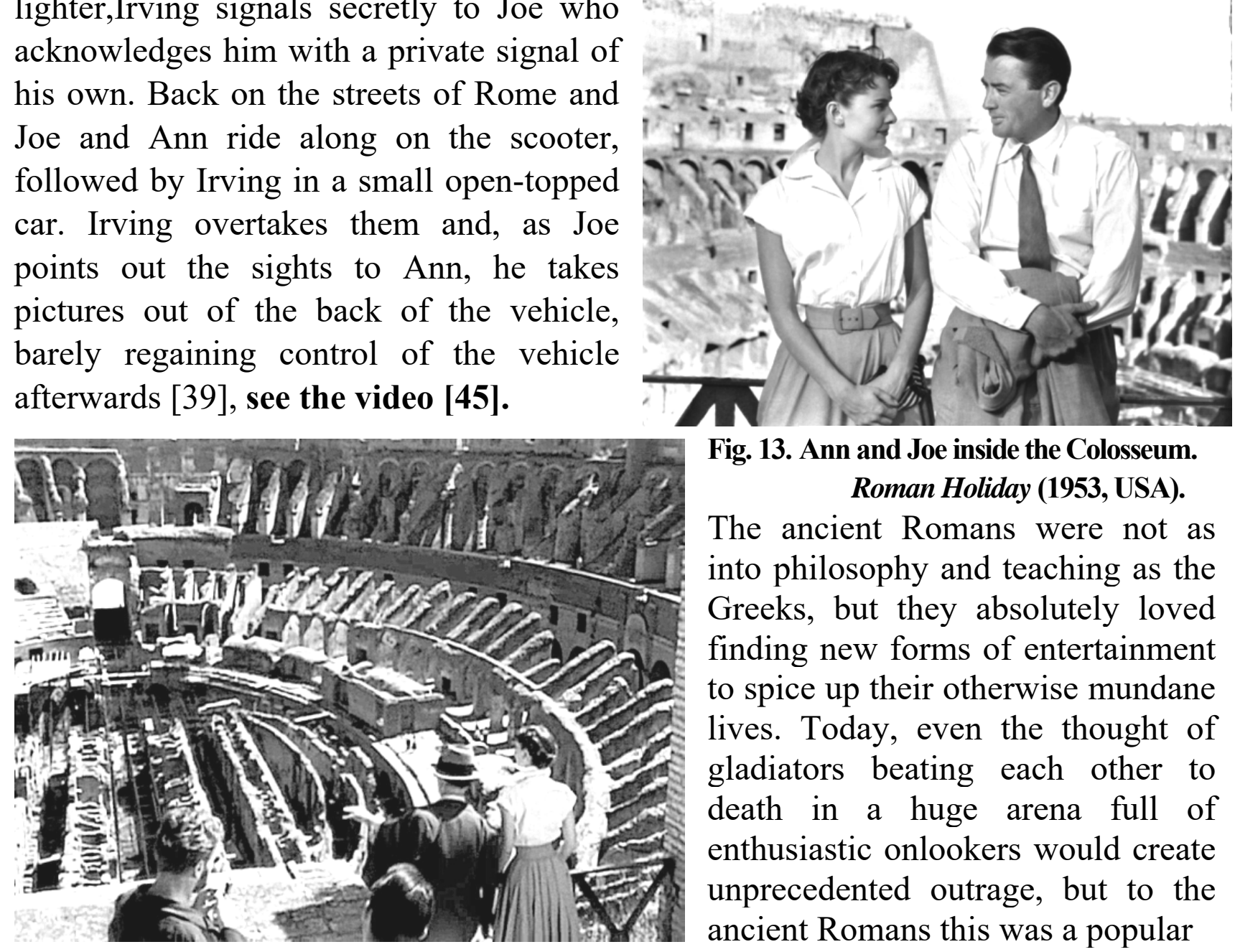

Fig. 13. Ann and Joe inside the Colosseum. Roman Holiday (1953, USA).

The ancient Romans were not as into philosophy and teaching as the Greeks, but they absolutely loved finding new forms of entertainment to spice up their otherwise mundane lives. Today, even the thought of gladiators beating each other to death in a huge arena full of enthusiastic onlookers would create unprecedented outrage, but to the ancient Romans this was a popular Fig. 14. Roman Holiday (1953, USA). The Colosseum. and common form of entertainment.
However, despite the short life expectancy, being a gladiator was in many ways one of the most glamorous professions in ancient Rome. Gladiator battles would draw thousands of spectators, including the biggest names in contemporary Roman society (see video [53]), Fig. 15, 16.

The Colosseum, is not only the symbol of the city but is also one of the most famous monuments in the world, was started by Vespasiano but finished by Tito in $80 \mathrm{AD}$ and opened to the public with a special inauguration 100 days long. It was constructed to give Rome a place worthy of its famous Gladiators Games [35; 15].

In order to honor the most popular of these ancient Roman superstars, here is the list of the top 10 ancient Roman gladiators [53; 45 (text)], Fig. 18.

The Romans were very blood thirsty, especially when it came to entertainment. It is estimated that 500,000 men and over 1 million animals were killed in the Colosseum. Archaeologists have spent years on the excavation and preservation of 
the hypogeum, the under-floor complex where gladiators trained and animals were raised with lifts, above [20], (Fig. 15, 17), see the video [5].

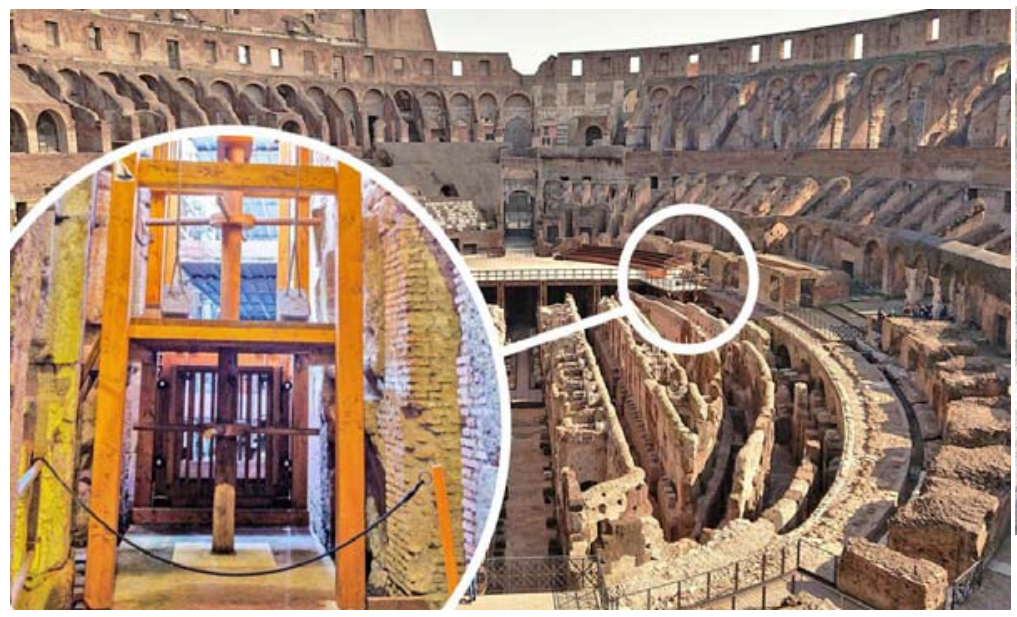

Fig. 15. The hypogeum, the under-floor complex.

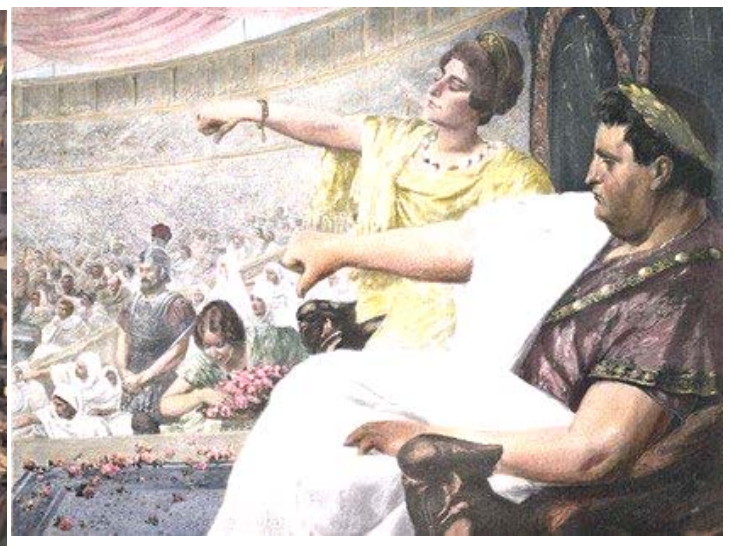

Fig. 16. The Roman emperor Nero. The first century AD in Rome.

Hidden from the 50,000 bloodthirsty fans 2,000 years ago, the basement has been opened to visitors for the first time, offering a close-up look at the secret heart of the historic venue. The cramped corridors beneath Rome's Colosseum were a frightening place where gladiators prepared for combat and slaves pushed wild beasts into lifts to propel them into the arena above. "This was the backstage of the Colosseum, a monument within a monument which has now been fully restored and reopened," Alfonsina Russo, director of the Colosseum, said (2021) [20], see video [49].

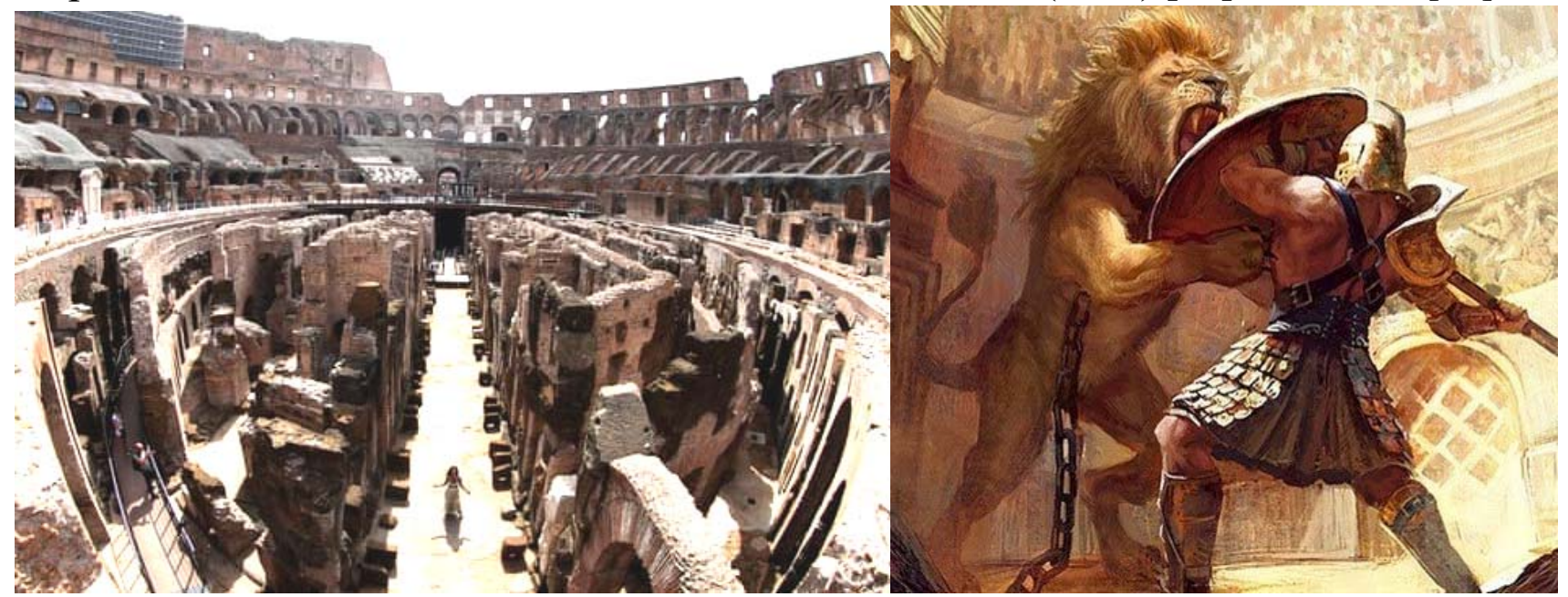

Fig. 17. The hypogeum.

Fig. 18. Gladiator Carpophorus.

The Roman amphitheatre, completed under Emperor Titus in AD 80, once had a wooden floor covered with sand that was built on top of a network of tunnels and rooms where gladiators and animals waited before entering the arena. But the floor was removed in the late $1800 \mathrm{~s}$ when archaeologists began to excavate the subterranean levels of the structure. The underground area was opened to the public in 2010 and visitors can also see the tunnels when they look down from what were the tiered rows of seats [18], see the video [19].

The new, hi-tech stage will be able to quickly cover or uncover the underground networks below, allowing them to be protected from the rain or to be aired out. The idea of rebuilding the arena of the Colosseum, the biggest amphitheatre 
constructed during the Roman empire, was first mooted by archaeologist Daniele Manacorda in 2014. The idea was supported by Franceschini, who said at the time the arena could also be used for re-enactments of the gladiator battles. In Roman times, crowds would fill the Colosseum to watch gladiators defeat animals including bears, tigers, elephants and rhinoceros $[18 ; 54]$.

Milan Ingegneria, a structural engineering and architecture firm, has won an $€ 18.5 \mathrm{~m}(£ 16 \mathrm{~m})$ bid to build and install a retractable arena floor that will allow visitors "to see the majesty of the monument" from its centre, culture minister Dario Franceschini said. The project is expected to be completed within the next two years."In 2023, we will have the splendour of the Colosseum with its arena again,"

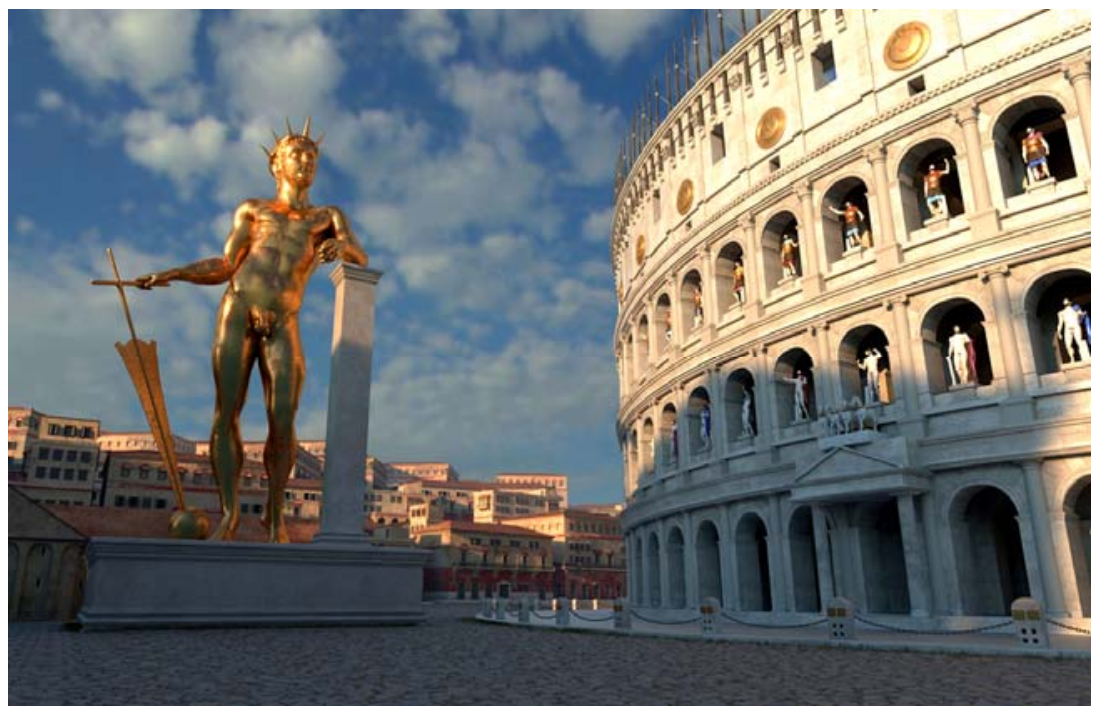

Fig. 19. The Colossus of Nero.

Franceschini added [18].

But why was it decided to call it the Colosseum? The Colosseum is the most visited attraction in Rome, originally called the Flavian Amphitheatre; yet Colosseum is a nickname from the middle ages recalling not the size of the gladiatorial arena but of an entirely different monument - a gigantic bronze statue so-called The Colossus of Nero (Fig. 19, 21). Ancient writers tell of an enormous bronze statue commissioned by the narcissistic and crazed young emperor Nero for the entrance of his party palace the 'Domus Aurea' (built after the 'Great Fire' of 64 AD). Tradition has it that the statue was of the emperor Nero (Fig. 16) posing as the sun god Sol, an attempt by Nero to grasp divine status while still living. There are many stories about the statue, its size, the face (Fig. 20) and what happened to it. Several emperors changed the face of the statue, adding their own likeness or removing that of an earlier emperor. Yet despite its association with an apparently crazed and despotic ruler the statue endured for at least three hundred years [7], see video [46].

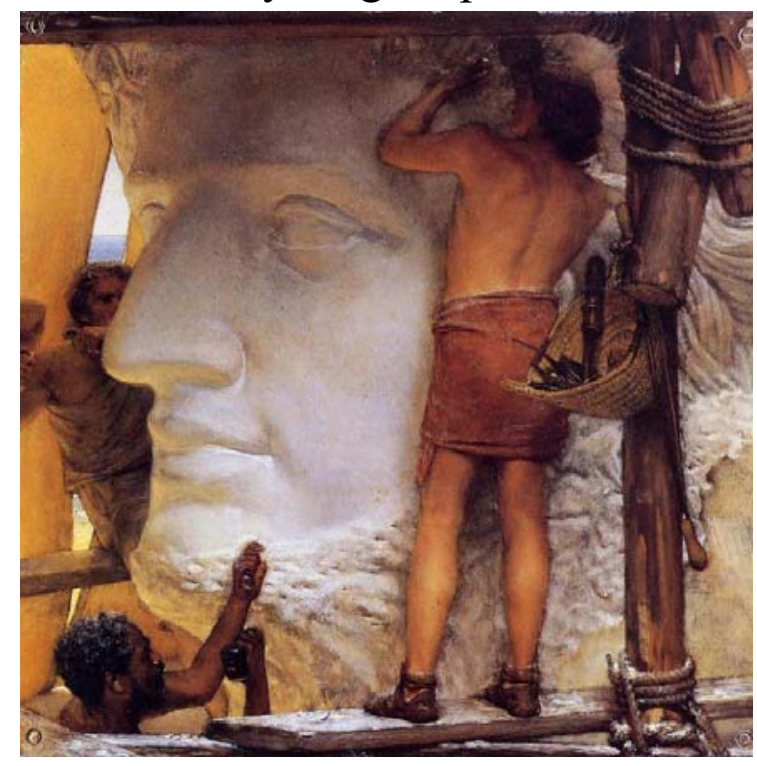

\section{Fig. 20. The face of The Colossus of Nero.}

Three main sources are Pliny, Suetonius and Cassius Dio, all writing at different times and they do not agree. Pliny tells us he visited Zenodorus' workshop and so perhaps is the most reliable. 'Summoned to Rome by Nero, he made a colossus 
$106 \frac{1}{2}$ feet tall'; the text is corrupted, some claim it reads 119 feet, or it may have been copied wrongly by later writers. Suetonius tells us it was 120 -foot-tall and Cassius Dio writing over a hundred years later tells us one hundred feet high. The statue wore a crown with rays (of sun) coming out of it - was this included in the height of the colossus? (see the video [60] 1:20 min).

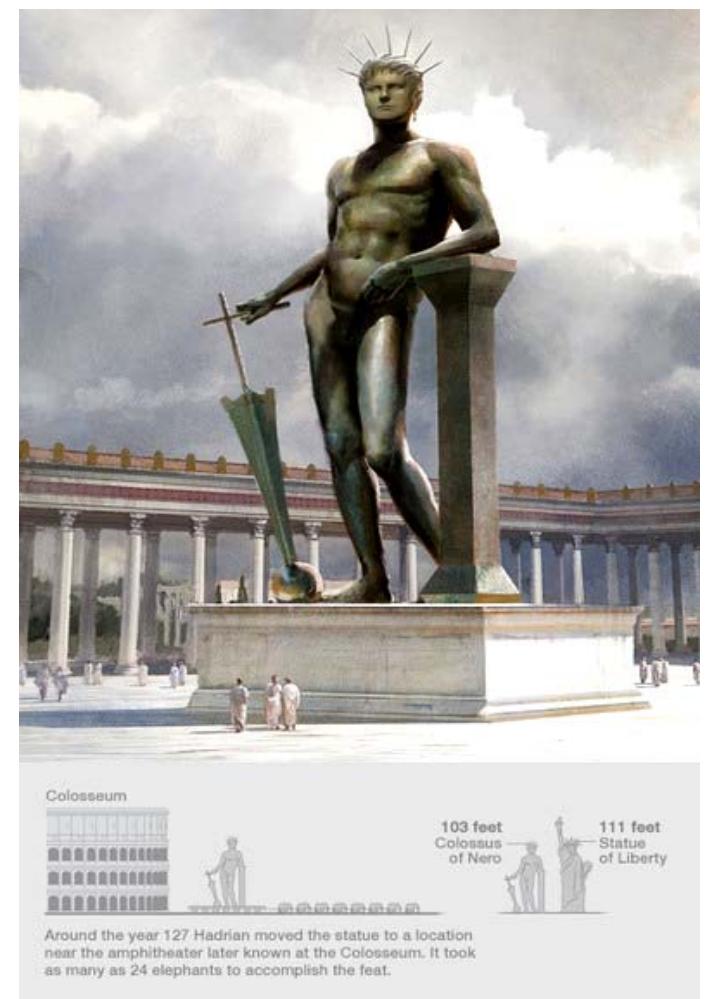

Over fifty years later Hadrian placed the statue on a marble covered base next to the Flavian Amphitheatre. So, the colossus was somewhere between $106 \mathrm{ft}$ and $120 \mathrm{ft}$ with or without its crown and base [7], Fig. 19, 21.

The last mention of the statue is in 354 $\mathrm{AD}$ and many believe it was destroyed in the sack of 410, or brought down by earthquakes shortly after. Yet a statement from the 7th century Saint Venerable Bede (Fig. 22), English Benedictine monk suggests it may have still been there in

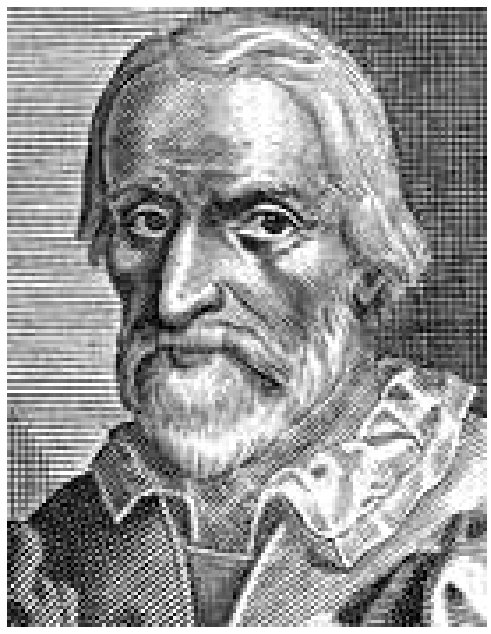

Fig. 21. 'So long as the Colossus stands, Rome shall stand...'

Fig. 22. Portrait of Saint Bede. medieval times: 'So long as the Colossus stands, Rome shall stand; when the Colossus falls, Rome too shall fall; and when Rome falls, so falls the world' [7]. (Fig. 21).

St Bede ['bi:da] - also known as the Venerable Bede - is widely regarded as the greatest of all the Anglo-Saxon scholars. He wrote around 40 books mainly

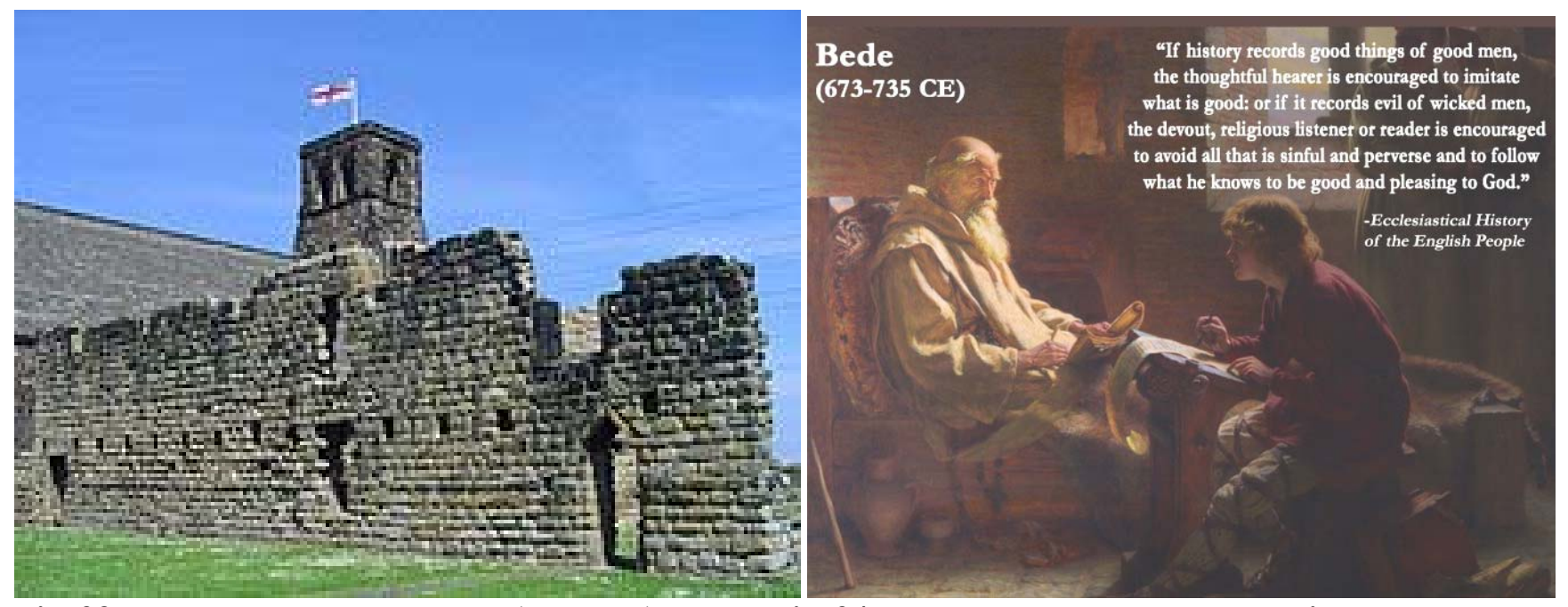

Fig. 23. The monastery at Jarrow (England).

Fig. 24. The Venerable Bede Translating the Last Chapter of St John' (1926) by James Doyle Penrose. 
dealing with theology and history. The Venerable Bede (673 AD-735 AD) was probably born in Monkton, Durham. Nothing is known of his family background. At the age of seven he was entrusted to the care of Benedict Biscop, who is $674 \mathrm{AD}$ had founded the monastery of St Peter at Wearmouth. In $682 \mathrm{AD}$, Bede moved the monastery at Jarrow (Fig. 23), where he spent the rest of his life. By the age of 19 he had become a deacon and was promoted to priest at 30 . His scholarship covered a huge range of subjects, including commentaries on the bible, observations of nature, music and poetry.

His writings reveal how the values of Christianity were implanted and integrated within the violent warrior society that existed at that time His most famous work, which is a key source for the understanding of early British history and the arrival of Christianity, is 'Historia Ecclesiastica Gentis Anglorum' or 'The Ecclesiastical History of the English People' which was completed in 731 AD. It is the first work of history in which the AD system of dating is used. Written towards the end of his life and dedicated to King Ceolwulf of Northumbria, 'The Ecclesiastical History' represented the culmination of Bede's lifetime's work. In it, not only did he leave a coherent record of the heroic foundation of early Christianity in England, but it also set an example of how this was successfully achieved. Bede is also concerned to show the unity of the English, despite the disparate kingdoms that still existed when he was writing. [14; 10].

Bede died in his cell at the monastery in May 735 AD (Fig. 23, 24).

Today, Bede is widely recognised as the greatest Anglo-Saxon scholar of his day, and by many as the greatest English historian of all time (see videos [43]):

If history records good things of good men,

the thoughtful hearer is encouraged to imitate

what is good: or if it records evil of wicked men,

the devout, religious listener or reader is encouraged

to avoid all that is sinful and perverse and to follow

what he knows to be good and pleasing to God.

(From the preface of Bede's Ecclesiastical History of the English People (and relevant letters), translated by Leo Sherley-Pride, R. E. Latham and D. H. Farmer (Penguin Classics, 2003). URI : https://thehistorianshut.com/2017/08/15/bede-2/)

Also, "a Roman holiday" - entertainment acquired at the expense of others' suffering, or a spectacle yielding such entertainment (Webster's New World College Dictionary, 4th Edition. Copyright $\left({ }^{\circ} 2010\right.$ by Houghton Mifflin Harcourt. All rights reserved).

"A Roman holiday" (noun):1) a public spectacle or controversy marked by barbarism, vindictiveness, or scandal; 2) pleasure or advantage gained from the discomfort or suffering of others.

(Most material @ 2005, 1997, 1991 by Penguin Random House LLC. Modified entries $(2019$ by Penguin Random House LLC and HarperCollins Publishers Ltd)

We also want to add that an instance in which someone experiences enjoyment on account of someone else's suffering. The expression, first used in this sense in 
Byron's "Childe Harold" (IV, 141) [11; 26] (Fig. 25, 26), derives from the fact that the Roman Empire frequently proclaimed work-free days on which to hold gladiatorial games. "A Roman holiday" can function as a loose equivalent of the German term Schadenfreude, which also means pleasure derived from another person's misfortune [52]:

....He reck'd not of the life he lost nor prize,

But where his rude hut by the Danube lay,

There were his young barbarians all at play,

There was their Dacian mother -- he, their sire,

Butcher'd to make a Roman holiday --

All this rush'd with his blood -- Shall he expire

And unavenged? -- Arise! ye Goths, and glut your ire! [11], Fig. 26, .27.

As we have mentioned earlier in our article, the famous statement of The Venerable Bede 'So long as the Colossus stands, Rome shall stand...' is considered in the context of studying the Colosseum in Rome. Therefore, note that these words were remembered by Lord Byron in his poem "Childe Harold's Pilgrimage" (1812-1818) in

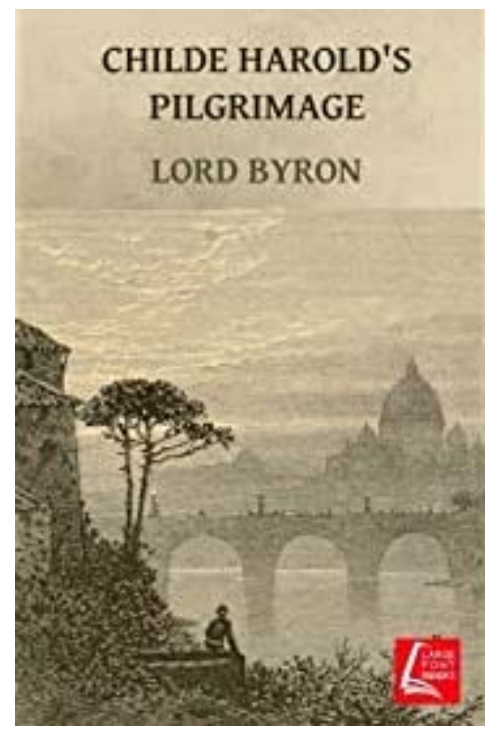

Canto IV (Fig. 27):

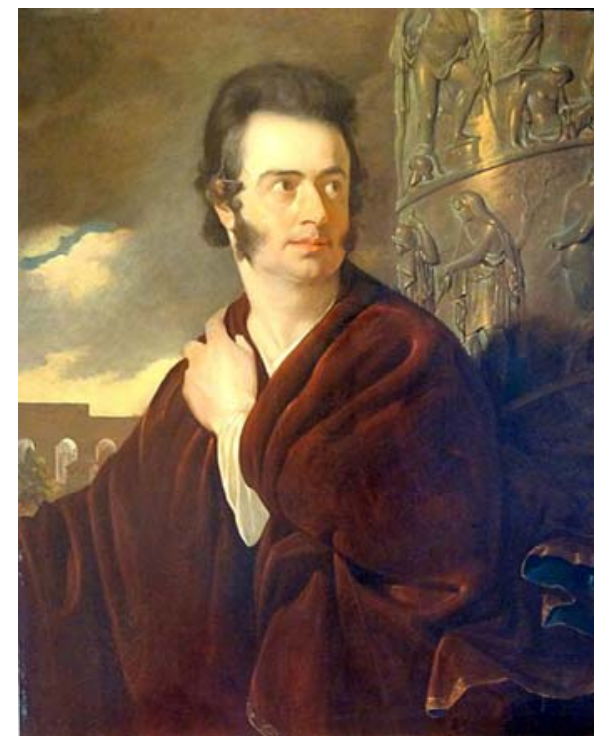

Fig. 26. Portrait of Lord Byron (1814).
Fig. 25. Childe Harold's Pilgrimage ( ed. 2018) by Lord Byron.

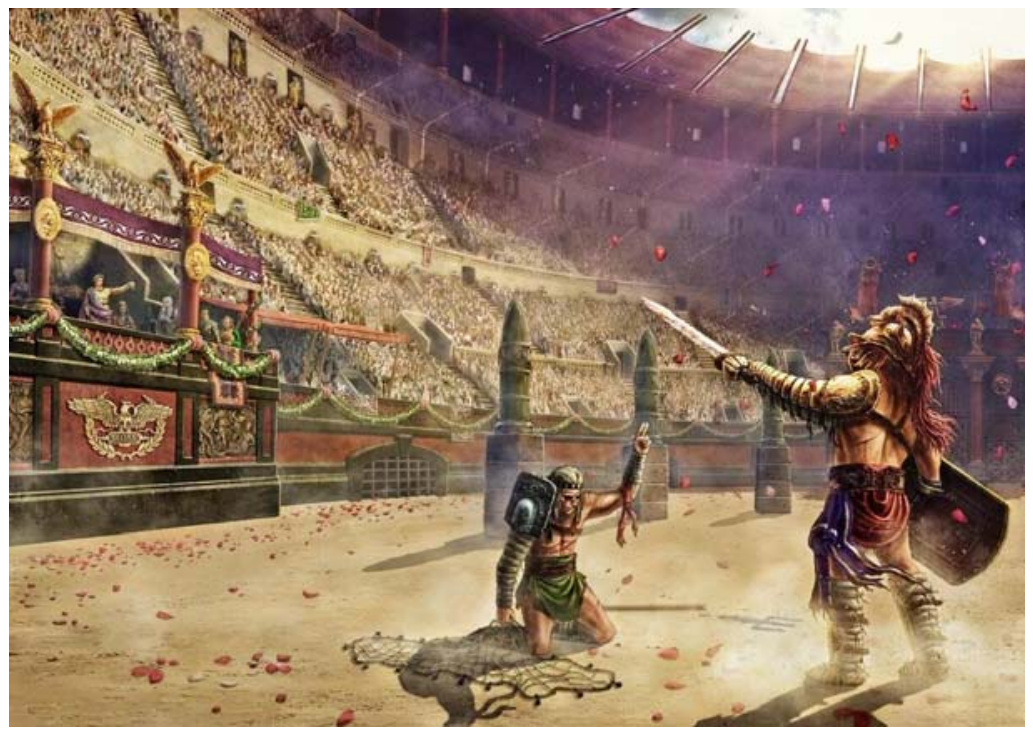

Fig. 27. A Roman holiday in the Coliseum.

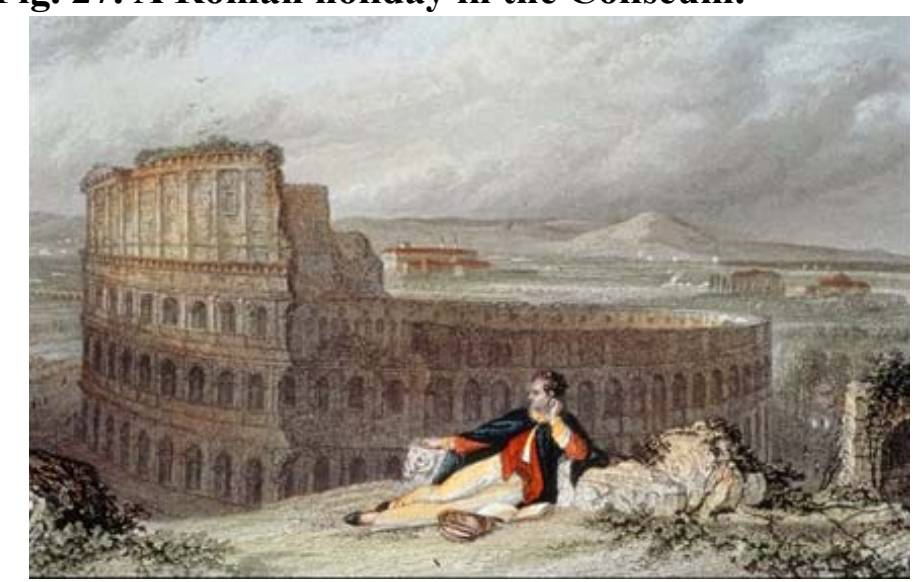

'While stands the Coliseum, Rome shall stand; When falls the Coliseum, Rome shall fall; And when Rome falls -- the World.' From our own land

Thus spake the pilgrims o'er this mighty wall In Saxon times, which we are wont to call Ancient; and these three mortal things are still On their foundations, and unalter'd all; Rome and her Ruin past Redemption's skill, The world, the same wide den -- of thieves, or what ye will... [11;27], Fig. 28.

Fig. 28. Lord Byron contemplating the Coliseum (about 1817) by Thomas Phillips. 
The Colosseum was built by the emperor Vespasian (see videos $[57 ; 61 ; 51]$ ), with construction starting in 72 BC, ending eight years later. His son, Titus (Fig. 19), inaugurated the Colosseum with 100 days of games, which included mock naval battles (in about one metre of water ([videos $[48 ; \mathbf{1 6}]$ ), execution of animals, and gladiator combat. According to ancient historian Eutropius, 5,000 animals were killed during those inaugural games (see the video [49]).

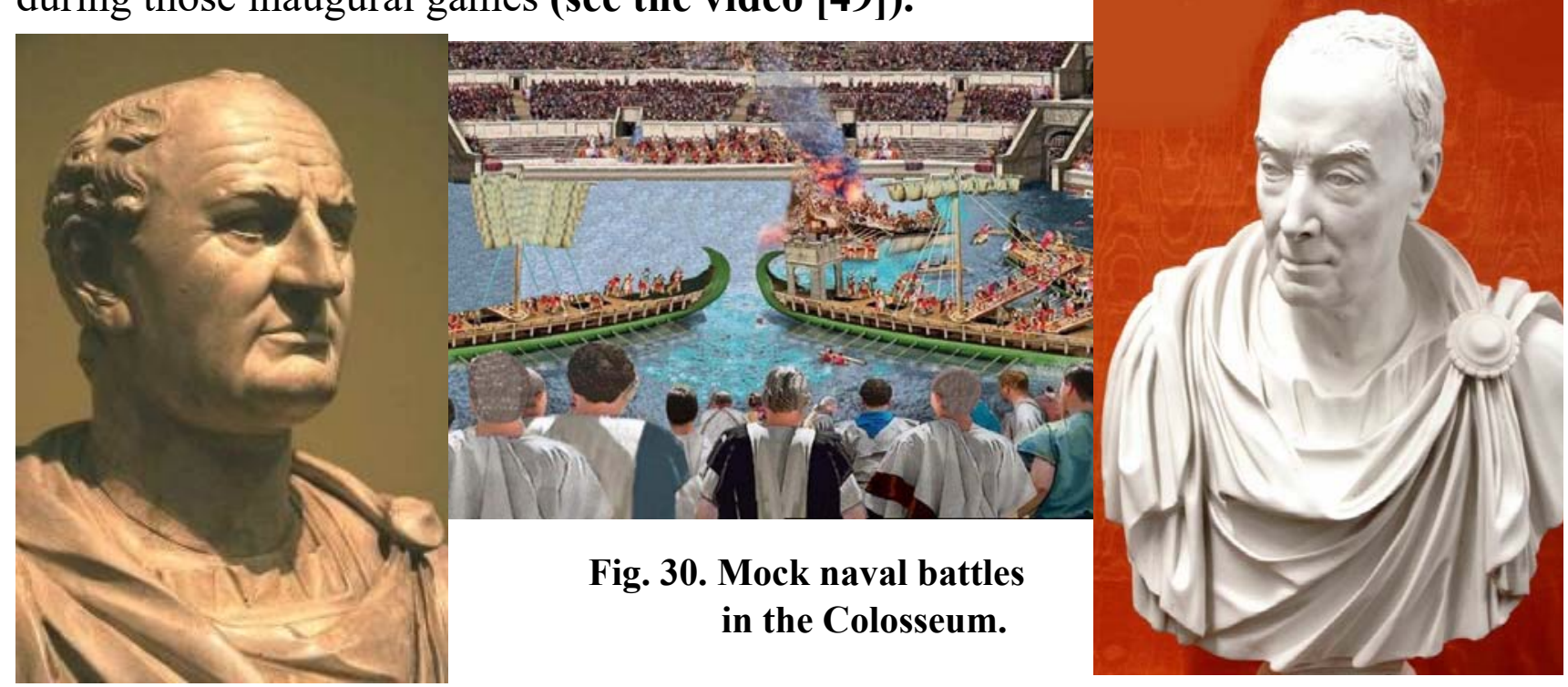

Fig. 29. The emperor Vespasian.

Fig. 31. The emperor Titus.

In its heyday, the amphitheater could host between 50,000 and 70,000 spectators [30].

But the rivalrous brother of Titus, Domitian (emperor 81-96), was quick to have a basement built with ring-formed walls and narrow passages. A series of winches and the capstans would have allowed teams of slaves to pull in unison and hoist heavy animals from the basement to the main arena, and this machinery has been reconstructed. After the fall of the Roman Empire, it was used as housing and as source of material for other construction work around the city [30], see videos [14].

And now, at about the centre of the Roman Forum in Rome, stand three pillars that support the remains of a horizontal frieze. This is what remains of a temple dedicated to the defiled Emperor Vespasian and his

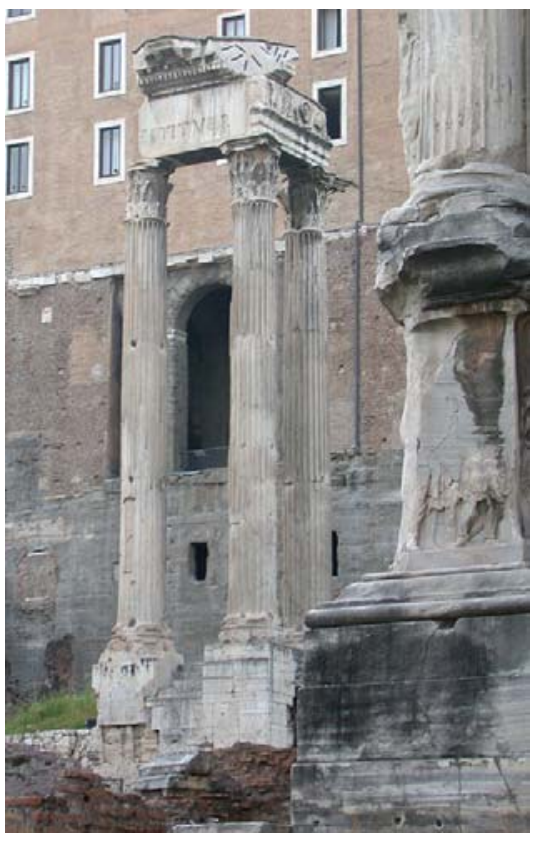
defiled son Titus, who both ruled Fig. 32. The Temple of Emperor Vespasian and his son Titus. at the end of the 1st century AD. It was their son and brother, the Emperor Domitian, who erected this temple. The building thus illustrates a key step in the design of the empire: the deification of Vespasian and Titus after their death [50].

Award-winning historian Bettany Hughes is on a mission that will take us across Italy's ancient sites and into the psyches of the emperors, gladiators, and generals of the Roman Empire in documantary Eight Days That Made Rome (2017). Explore the rise and fall of one of history's most extraordinary reigns, defined by 
eight critical days. From the defeat of the Carthaginian Empire to Julius Caesar's crossing the Rubicon River to Constantine's conversion to Christianity, explore this remarkable period and meet its key figures [14].

At last. Everything about the movie fascinated us. More importantly though, it was the effortless charm of the film Roman Holiday that struck us greatly. This film though, really does belong to Audrey Hupbern $[22 ; 23]$. Her performance at the age

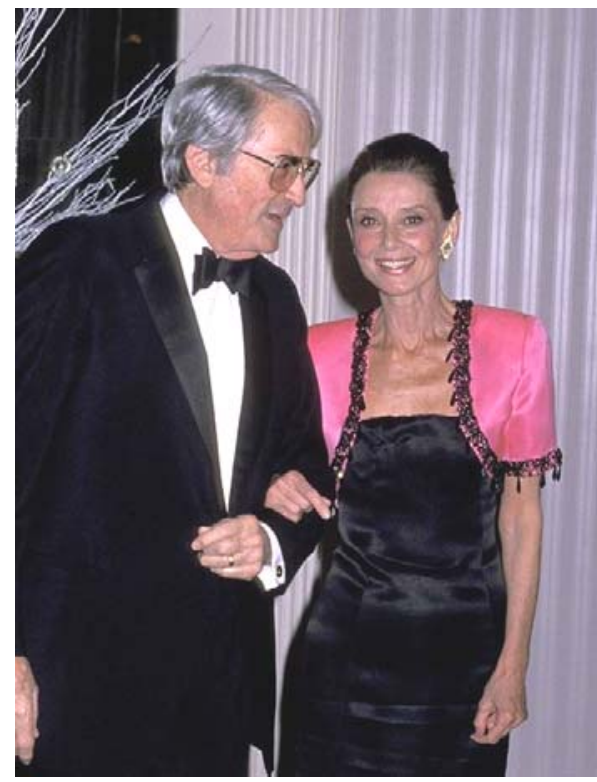
of 23 was just the perfect mix of sprightly innocence and delightful charisma that even the simplest things are a pleasure to watch (Fig. 34, 36). We think the simplicity of the story, as well as the lovely mix of lighthearted humour and sweet poignancy, make Roman Holiday

(1953) truly unique.

To sum up, when we think about this movie, probably the first scene that comes to our minds is the Vespa scene. The iconic Vespa ride (Fig. 3, 4,36) that Fig. 33. G. Peck and A. Hupbern (1988). made us all dream of having a similar experience, especially in the moment in which the Colosseum is the background. This is a stunning view that is worth seeing at least once in life.

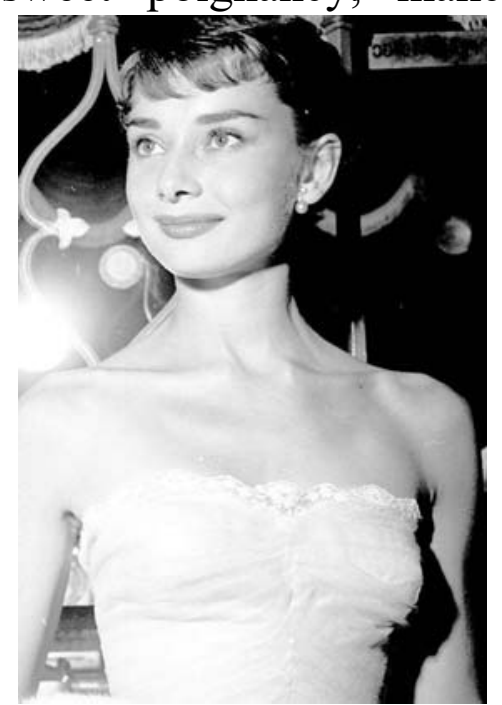

Fig. 34. Audrey Hupbern at the premiere of 'Roman Holiday' (1953).

During the duration of the Roman Empire the Colosseum was restored on various occasions because of the many fires and earthquakes that hit it over the years. The history behind this work of architectural splendor is absolutely fascinating and well-worth learning about (Fig. 35).

The film Roman Holiday (1953) is a great guide for everybody who loves traveling, watching movies and series and visiting filming locations.

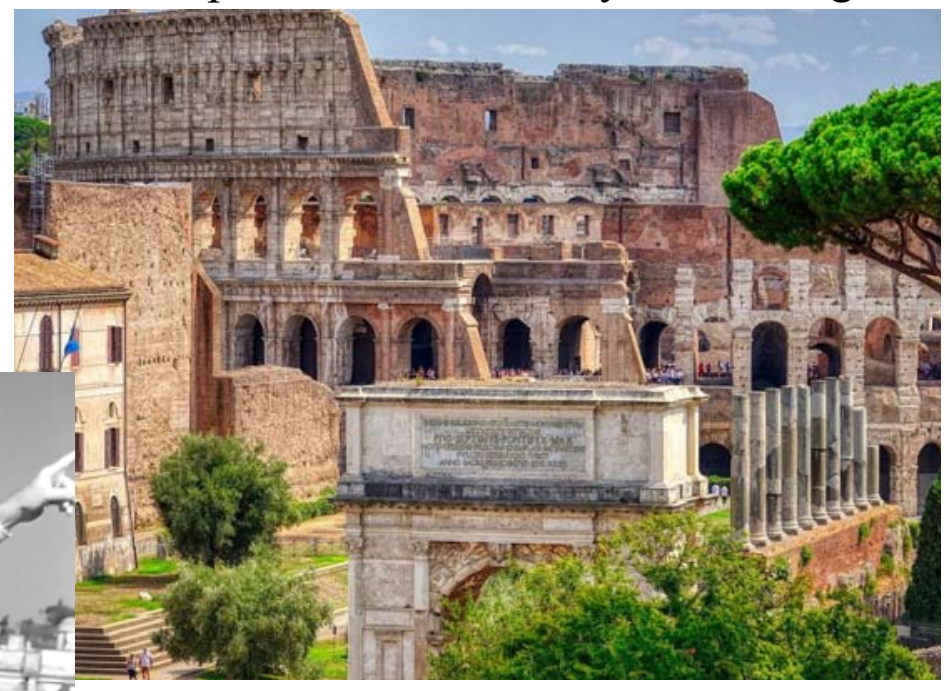

Fig. 35. The Colosseum, Rome.

Fig. 36. Roman Holiday (1953). The movie duye G. Peck and A. Hupbern. The iconic Vespa ride around Rome. 


\section{References}

1. Ancient Colosseum: A Virtual reality experience with Oculus Rift. URI : https://www.youtube.com/watch?v=bAWTJO6oz-o

2. Ancient Rome reconstructed. URI : https://www.youtube.com/watch?v=OfwoX3Vyjua

\section{(from 15.10 min.)}
3. Childe
Harold's
Pilgrimage.
Canto
IV.
URL :

https://petercochran.files.wordpress.com/2009/03/chp4.pdf

4. Chornyi M. 'Roman Holiday' Filming Locations. URL :

https://www.recenzent.org.ua/roman-holiday-filming-locations/
5. Colosseum
reconstructed $\mathrm{c}$.
by
archeolibri
s.r.l.
URL :

https://www.youtube.com/watch? $\mathrm{v}=8 \mathrm{sLy} 5 \mathrm{VCMuKM}$

6. Colosseum, Rome

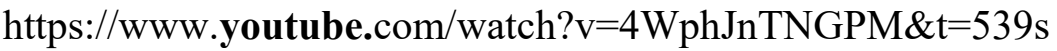

[HD].

URL :

7. Colossus of Nero. URI : https://colosseum.info/colossus-of-nero/

8. Eyewitness Travel Family Guide to Italy: Rome and Lozio. London : Dorling Kindersley Publishing Pvt

Ltd,

2014.

https://books.google.com.ua/books?id=FHpAAwAAQBAJ\&pg=PT198\&lpg=PT198\&dq=video+The+ Colosseum + in + the + film $+\ll$ Roman + Holiday $» \&$ source= $=$ l\&ots $=$ bp $8 I n-$

i1SS\&sig=ACfU3U2dWnWgSjjya71BvVNfzNGad9t3Lg\&hl=ru\&sa=X\&ved=2ahUKEwi78aSCr5 XyAhVEgf0HHWD5A3AQ6AF6BAgGEAM\#v=onepage $\& q=$ video $\% 20$ The $\% 20$ Colosseum $\% 20 \mathrm{in}$ $\% 20$ the $\% 20$ film $\% 20 \ll$ Roman $\% 20$ Holiday»\&f=false

9. Fesyna A., Pet'ko L., Turchynova G. Spanish Steps in Rome and movie Roman Holiday (1953) : Abstracts of the $\mathrm{V}^{\text {th }}$ International Scientific and Practical Conference «Theoretical and scientific bases of development of scientific thought» (Rome, February 16-19, 2021). Italy, Rome : Bookwire $^{\mathrm{TM}}$. 2021. Pp. 152-161.

URL http://enpuir.npu.edu.ua/handle/123456789/33239

10. Johnson Ben. The Venerable Bede. URI : https://www.historicuk.com/HistoryUK/HistoryofEngland/The-Venerable-Bede/

11. George Gordon, Lord Byron. Childe Harold's Pilgrimage. Canto the Fourth. URI : http://knarf.english.upenn.edu/Byron/charold4.html

12. Herasymchuk Y., Pet'ko L. English Romantic Poets John Keats and Percy Bysshe Shelley in Rome and The Legendary Movie "Roman Holiday" // Topical issues of practice and science: abstracts of the XXVI ${ }^{\text {th }}$ International scientific-practical conference (London, 18-21 May 2021). Great Britain. London: Bookwire $^{\mathrm{TM}} .2021 .835$ p. Pp. 138-149. URI : http://enpuir.npu.edu.ua/handle/123456789/34070

13. Herasymchuk Y., Pet'ko L., Turchynova G. The Spanish Square in Rome and movie Roman Holiday. Multidisciplinary research : abstracts of the XIV ${ }^{\text {th }}$ International scientific-practical conference (Bilbao, 21-24 December 2020). Spain. Bilbao: International Science Group, 2020. Pp. 113-123.

URI : http://enpuir.npu.edu.ua/handle/123456789/32566
14. History.
The
Venerable
Bede
(673 AD-735 AD).
URI : http://www.bbc.co.uk/history/historic_figures/bede_st.shtml

15. Hopkins Keith. The Colosseum: Emblem of Rome. BBC. History. URI : http://www.bbc.co.uk/history/ancient/romans/colosseum_01.shtml

16. How Romans flooded the Colosseum for sea battles. URI : https://www.ted.com/talks/janelle_peters_how_romans_flooded_the_colosseum_for_sea_battles/tra nscript

17. How the Roman Colosseum Was Built. URL :

https: //www.youtube.com/watch?v=09meiYkTsBo\&t=32s

18. Giuffrida Angela. Rome's Colosseum to gain hi-tech arena floor. The Guardian. Sun 2 May 2021. URL : https://www.theguardian.com/world/2021/may/02/rome-colosseum-to-gain-hitech-arena-floor 
19. Inside and Underground Secrets of the Colosseum. Rome Travel Italy. URI : https://www.youtube.com/watch?v=EEPzsLHkRns

20. Kington Tom. Colosseum's lifts return from depths of history. The Times. Saturday June 26 2021. URL : https://www.thetimes.co.uk/article/colosseums-lifts-return-from-depths-of-history$5 \mathrm{p} 8 \mathrm{pnkn} 7 \mathrm{p}$

21. Know about the magnificent infrastructural work of imperial Rome, especially Roman masonry. URI : https://www.britannica.com/video/187678/infrastructure-masonry-Rome-Roman

22. Kirilchuk N., Pet'ko L. The Style Icon And The Rose "Audrey Hepburn": Abstracts of the IV ${ }^{\text {th }}$ International Scientific and Practical Conference «Prospects and achievements in applied and basic sciences» (Budapest, February 9-12, 2021). Hungary. Budapest : Bookwire $^{\mathrm{TM}}$. 2021. Pp. 57-72.

URL : http://enpuir.npu.edu.ua/handle/123456789/33212

23. Klymenko N., Pet'ko L. The image of British actress Audrey Hepburn in a rose named after "most beautiful woman of all time". Topical Issues of Science and Practice : abstracts of VII Sientific and Practical Conference (London, 02-06 November 2020). Great Britain, London : International Science Group, 2020. 781 p. Pp. 42-51.

24. Kruhlova A., Pet'ko L. "Oh, Tiber, Father Tiber!" and movie Roman Holiday (1953) : Abstracts of the $\mathrm{V}^{\text {th }}$ International Scientific and Practical Conference «Theoretical and scientific bases of development of scientific thought» (Rome, February 16-19, 2021). Italy, Rome : Bookwire $^{\mathrm{TM}}$. 2021. Pp. 162-171.

URL http://enpuir.npu.edu.ua/handle/123456789/33253

25. Kruhlova A., Pet'ko L. "Roman Holiday" (1953) filming locations in Rome: Tiber River // Trends in the development of modern scientific. Abstracts of XXXI International Scientific and
Practical
Conference.
Vancouver,
Canada.
2021.
Pp. 102-116.

URI : ttp://enpuir.npu.edu.ua/handle/123456789/34665

26. Lord Byron. Childe Harold's Pilgrimage. Publisher: CreateSpace Independent Publishing Platform, 2018. 128 p.

27. Childe Harold's Pilgrimage Canto IV Full Audiobook by George Gordon by Narratives.

URI : https://www.youtube.com/watch?v=UU1VEFSubA8

28. Machak V., Pet'ko L. The Pantheon. Rose Petals and the Film "Roman Holiday" // Science and practice, problems and innovations: Abstracts of VII International Scientific and Practical Conference. Ottawa, Canada, 2021, pp. 53-68.

URL : http://enpuir.npu.edu.ua/handle/123456789/33285

29. Melnychuk A., Pet'ko L. Palazzo Brancaccio in the film "Roman Holiday" (1953) // Interaction of society and science: problems and prospects : abstracts of the XXX International Science Conference (London, May 18-21, 2021). Great Britain. London : Bookwire ${ }^{\mathrm{TM}}$. 2021. Pp. 126-139. URI : http://enpuir.npu.edu.ua/handle/123456789/34579

30. Messia Hada. Rome's Colosseum opens its underground for the first time in its history. $C N N$ Travel. $25^{\text {th }}$ June 2021. URI: https://edition.cnn.com/travel/article/colosseum-rome-undergroundhypogea/index.html

31. Pet'ko Lyudmila. Teaching methods and the formation of professionally oriented foreign language learning environment in conditions of university. Intellectual Archive. 2016. Volume 5. No. 4 (July/August). Toronto : Shiny Word Corp., Canada. PP. 73-87.

32. Ray Sanjana. The Colosseum Opens Its Underground Tunnels to Tourists. National Geographic Traveller India. June 30, 2021. URI : http://www.natgeotraveller.in/the-colosseumopens-its-underground-tunnels-to-tourists/

33. Rome, Italy: The Colosseum. URI :

https://www.youtube.com/watch?v=xaSbYIeqGWg

34. Roman Holiday (1953). URL : http://filmatika.ru/english_movies/roman-holiday/ with

\section{English subtitles}

35. Roman Holiday, a movie that made the History of Cinema. URI : https://www.romeprivateguides.com/en/blog/about-rome/roman-holiday.html 
36. Roman Holiday: movie. 1953 (USA). Starring: Gregory Peck, Audrey Hepburn. Director: William Wyler. URI : https://www.dailymotion.com/video/x3rp5md (in English)

37. Roman Holiday (1953). Film locations then and now. URL:

https://www.youtube.com/watch?v=6YIs8xaKCOA

38. Roman Holiday (1953) - (Movie Clip) Scooter. URI :

https://www.tcm.com/video/1066945/roman-holiday-1953-scooter

39. Roman Holiday (1953) Script. URI :

http://www.script-o-rama.com/movie_scripts/r/roman-holiday-script-transcript.html

40. Roman Holiday (1953). Spoilers for Roman Holiday, Sabrina, Breakfast at Tiffany's and

Spartacus. URI : http://hal0000.blogspot.com/2009/02/roman-holiday-1953.html

41. Roman Holiday (1953). The Blonde at the Film. A fresh look at old films. November 21,

2013. URI : https://theblondeatthefilm.com/2013/11/21/roman-holiday-1953/

42. Sohini Das Gupta. On a Roman Holiday Trail. National Geographic Traveller India.

August 23, 2019. URL : http://www.natgeotraveller.in/on-a-roman-holiday-trail/

43. St Bede. URI : https://www.youtube.com/watch?v=YfJa-fwB02I

44. Stabiner Karen. In Rome, Using 'Roman Holiday' as a Guide. New York Times. Oct. 18,

2016. URI : https://www.nytimes.com/2016/10/23/travel/roman-holiday-film-rome-italy-hepburnpeck.html

45. The Colosseum in the film «Roman Holiday». URL: https://youtube/dhJN1RLR1jI

46. The Colosseum Virtual Walking Tour in 4k. URL :

https://www.youtube.com/watch? $\mathrm{v}=\mathrm{eJeF} 7 \mathrm{hDB} 0 \mathrm{UA}$

47. The glory of Ancient Rome. All parts. Documentary. Collection. URI:

https://www.youtube.com/watch? $v=$ ZxRZBtMktHc

48. The Great Flood: Could the Colosseum Host Gigantic Sea Spectacles? | Blowing Up

History. URI : https://www.youtube.com/watch?v=xbOAXAaao0o

49. The Story Behind the Colosseum's Greatest Battle. URI :

https://www.youtube.com/watch? $\mathrm{v}=$ fbhuqovrrak

50. The Temple of Emperor Vespasian and his son Titus. URI :

http://en.cityzeum.com/p/the-temple-of-emperor-vespasian-and-his-son-titus

51. The Untold Story Of Emperor Vespasian | Vespasian | Odyssey. URI :

https://www.youtube.com/watch? $\mathrm{v}=\mathrm{bUdotxA} 0 \mathrm{ws} 8$

52. Top definition Roman holiday. URI :

https://www.urbandictionary.com/define.php?term=Roman\%20holiday

53. Top 10 Famous Ancient Roman Gladiators. URL :

https://www.youtube.com/watch? $=-56$ thbCUnT4\&t $=10 \mathrm{~s}$

54. Top 10 Famous Ancient Roman Gladiators (text format). URL :

https://www.ancienthistorylists.com/rome-history/top-10-famous-ancient-roman-gladiators/

55. Traveling through the movies - Roman Holiday. URL:

https://tvortravels.wordpress.com/2013/04/28/traveling-through-the-movies-roman-holiday/

56. Turchynova G, Pet'ko L., Holovko T. Studying Gardens of the World with Students of

Higher Education Establishments. Intellectual Archive. Toronto: Shiny Word.Corp. (Canada). 2020.

Vol. 9 (October/December). No. 4. Pp. 94-107.

DOI: 10.32370/IA_2020_12_12

57. Vespasian: Savior of Rome \& Father of the Colosseum. URI :

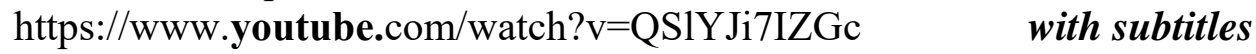

58. Vynohradova N., Pet'ko L. 'Roman Holiday' filming locations in Rome: Trinità dei Monti : Abstracts of the $\mathrm{V}^{\text {th }}$ International Scientific and Practical Conference «Theoretical and scientific bases of development of scientific thought» (Rome, February 16-19, 2021). Italy, Rome : Bookwire $^{\mathrm{TM}}$. 2021. Pp. 172-185.

URL : http://enpuir.npu.edu.ua/handle/123456789/33252

59. Yudytskyi B., Pet'ko L. Roman Forum and "Roman Holiday", a movie that made the

History of Cinema // Current issues of science and education: Abstracts of XIV International 
Scientific and Practical Conference (Rome, March 23-26, 2021). Italy, Rome : Bookwire ${ }^{\mathrm{TM}} .2021$, pp. 56-70.

URL : http://enpuir.npu.edu.ua/handle/123456789/33556

60. What happened to the missing half of the Colosseum? URI : https://www.youtube.com/watch?v=hIO8chsH_7U

61. Why Romans Adored Emperor Vespasian | Imperium: The Path To Power| Timeline. URI : https://www.youtube.com/watch?v=r72X5oUPTwM

\section{Translation of the Abstract to the Author's Language}

УДК 378.147:811.111]:791.5

Турчинова Г., Петько Л., Григорук Л. Колізей у фільмі «Римські канікули» (1953).

Стаття присвячена Колізею та фільму «Римські канікули» (1953, США). Це - перший голлівудський фільм, який був знятий і повністю оброблений в Італії. В історичному центрі міста мало що змінилося. Історія про принцесу Анну (актриса Одрі Хепберн), яка приїжджає 3 офіційним візитом до Риму і тікає одного вечора 3 посольства, та американського журналіста (Грегорі Пек), який дарує принцесі Анні захоплюючий день відпочинку в Римі, наповнений незабутніми враженнями. Ми бачимо прекрасні краєвиди Риму, відомі архитектурні пам'ятки, вулиці, площі, фонтани і мости. Місто - музей. Тож, коли Одрі Хепберн оглядає Колізей, вона справді оглядає Колізей. У фільмі "Римські канікули" принцеса Анна міцно тримається Джо, коли вони мчать дорогами повз знаменитий Колізей. Кінозірки, що їхали на «Веспі», створили знаковий кінопостер до фільму, під час важливої ери для італійського кіномистецтва.

Автори статті пропонують інноваційний підхід до формування професійно орієнтованого іншомовного освітнього середовища шляхом вивчення зйомок шедевра світового кінематографа «Римські канікули» (1953, США), на прикладі Колізею. Це типовий приклад, скопійований по всій імперії: надзвичайно декоративний зовнішній вигляд будівлі ззовні та всередині з підземними кімнатами під підлогою арени (гіпогеніум), щоб сховати людей, тварин та реквізит, поки вони чекають своєї участі у гладіаторських боях. «Театр смерті». Згадується найвідоміший англійський історик Беда, поема лорда Байрона "Паломництво Чайльда Гарольда", гладіатори.

Ключові слова: університет, професійно орієнтований іншомовний освітній простір, студенти, фільм «Римські канікули» (1953, США), Колізей, гіпогеум, англійський історикБеда Преподобний, лорд Байрон «Паломництво Чайльда Гарольда», гладіатори. 


\title{
Methods of Using the Google Classroom Service in Teaching Historical Disciplines During Blended and Distance Learning
}

\author{
Dmytro Nefyodov \\ Doctor of Historical Sciences \\ Associate Professor at the Department of History \\ V. O. Sukhomlynskyi National University of Mykolaiv \\ nefyodovdv@gmail.com
}

\begin{abstract}
The article deals with the methods of using the Google Classroom service in teaching historical disciplines during blended and distance learning. The author of the article has come to the conclusion that with the help of distance education technologies it is not only possible to put a number of routine pedagogical activities on a computer's shoulders, but to organize really qualitative, individual, differentiated teaching. In the author's opinion, in the Google Classroom service it is convenient and effective to work both for a teacher and a student/pupil, as the service provides the users with a generic working device, possesses a human-engineered interface and capabilities necessary for the participants of the educational process.

Key words: higher education institutions, comprehensive secondary institutions, Google Classroom, distance teaching/learning, blended teaching/learning
\end{abstract}

Present-day developments of digital technologies provide the opportunity of their active implementation into the educational process. At present we can highlight a distinct tendency of changing the role of digital technologies - from the common support of the educational process with technical means to formation of electronic educational resources (EER), computer-based learning environment (CBLE) and accomplishment of distance learning.

An advanced training session both in a comprehensive secondary institution (CSI) and in a higher education institution (HEI) can no longer be imagined without using information and communication technologies (ICT), without the combination of traditional teaching means and methods with the ICT tools. The implementation of modern information technologies into the educational process opens new opportunities of solving various pedagogical tasks. With spreading digital technologies teaching/learning takes the form of a continuous, individual-oriented, flexible and dynamic process.

Internet technologies that are quickly mastered by CSI and HEI give the graduating students self-confidence, create comfortable conditions for self-realization and creativity, 
increase their motivation to studies, enlarge their social circle, provide a great amount of various educational resources. And they also open a number of opportunities for a teacher: to highlight a theoretical issue more deeply, that helps the participants of the educational process to scrutinize thoroughly processes and phenomena, which could not be studied without using the interactive models; they are also the infinite possibilities for realization of inclusive education etc.

The present and the future of our pupils and students is a knowledgeable society. The academician Andrei Petrovich Semenov's statement "To teach a person to live in the information world is the most important task of the contemporary school" must become determinative in the work of every modern teacher.

In the light of these processes the distance teaching systems are to the fore today. These systems have long been known to the teachers of HEI. But CSI discovered the distance teaching relatively recently due to the quarantine with regard to the coronavirus pandemic and had to cope with it as fast as possible.

Let's give deeper consideration to the Google Classroom system, which has become widespread due to its simplicity and accessibility for the participants of the training process. For the last part of May 2014 the Google company began its limited testing of its educational platform "Classroom", intended for classroom studies. According to the Google information, for the first few months more than 100 thousand people from 45 countries enrolled to try this service. Today any person who has a Google account can start using it. This system of training can be used both on a computer and on a slate or a smartphone.

Access to this software is possible after a user's registration and receiving a normal user Google account.

With Google Classroom a user can make a training classroom or join the existing one. A number of training groups that a teacher can make and a pupil can be enrolled is unlimited.

While scheming an online-classroom a teacher (instructor) adheres to the following principles:

- of scientificity and feasible difficulties;

- of availability of education;

- of visibility;

- of awareness and creative activity; 
- of enriching and educative nature of teaching;

- of creating a positive emotional background.

In the Classroom you can use (download) textbooks, lectures, presentations on topics as well as videos from YouTube.

In Google Classroom teachers can easily and quickly make and check tasks in the electronic form, and also determine a delivery date. The tasks and pieces of work are then automatically systematized into the structure of folders and documents on Google Drive, understandable both to teachers and students. With the help of the service you can immediately see the tasks, which caused some problems while doing them.

The peculiarities of the Google Classroom system are as follows:

- the usage of only Google tools (Google Drive, Google Documents, Google Forms etc.);

- a common folder "Classroom" is made on Google Drive for the participants of the educational process;

- the folder "Classroom" is available both for the individual student and for the class (group) in general.

The advantages of the Google Classroom system are as follows:

- the functionality: the ability to publish the theoretical material, tasks, to post grades in the register, a calendar etc;

- the organization of collective work;

- the free-of-charge basis;

- the support of the Ukrainian language;

- the brand Google is known and used by everyone;

- this service can be used both on a personal computer and on a smartphone and a slate, as well as with the help of special mobile applications.

The Mykolaiv economic lyceum № 2 of the Mykolaiv city council activated the complimentary subscription to the G Suite for Education service since the first weeks of distance teaching/learning in March 2020.

Doctor of Historical Sciences, Associate Professor of the Department of History of Mykolaiv V.O. Sukhomlynskyi national university D.V. Nefyodov combines his work at the university and teaching disciplines of a social humanitarian cycle in the Mykolaiv economic 
lyceum № 2. Since the first days of moving to the distance teaching/learning he began to use the Google Classroom service in his work together with his colleagues.

Thus, each subject which is taught (History of Ukraine, World History, Foundations of Legal Studies, Civics) and each class (group) of the lyceum has the appropriate Classroom on the Google Classroom service.

In the Classroom all classes and lessons are arranged according to the usual timetable, the tasks and explanations for doing them are made and downloaded, the deadlines are set. Having done his homework each student sends it to the Classroom and after checking it by the teacher he gets a sufficient grade (fig. 1).

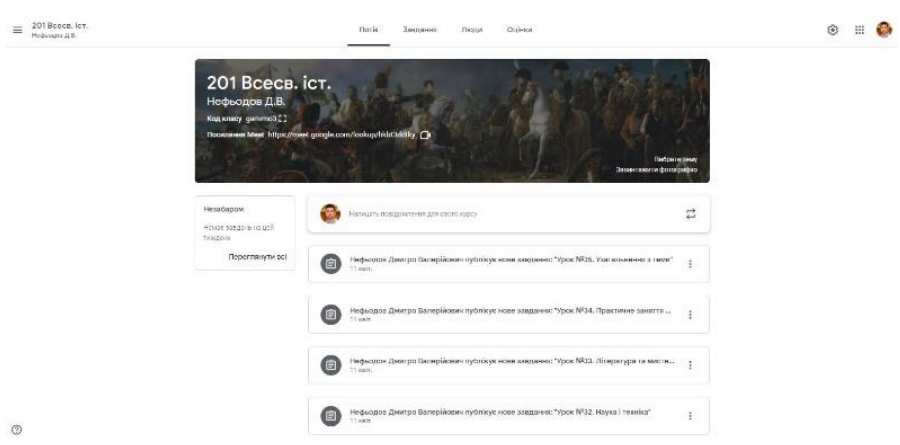

Fig. 1.

Besides that, the service has tools for arranging all the students' grades in the format of a register and striking an average grade for a topic, a semester, a year.

One of the most important tools of the Classroom is also the service "meet" - the opportunity to give classes in the format of a video-conference (fig. 2).

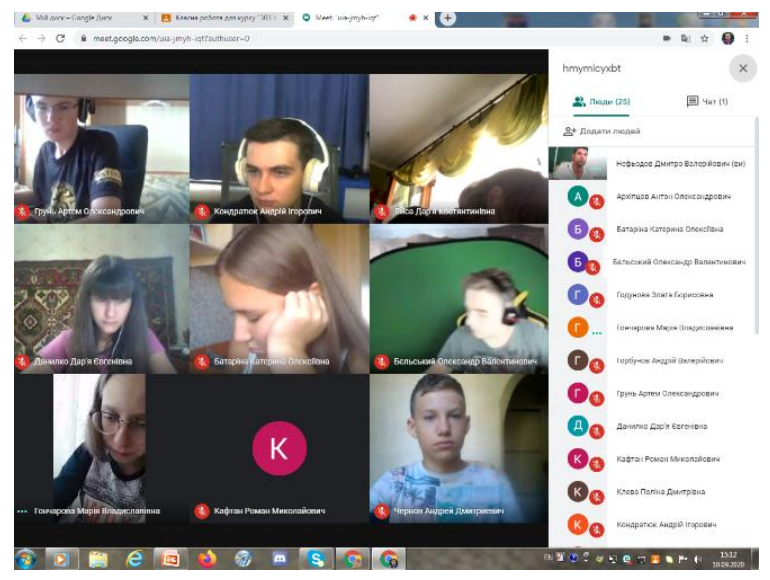

Fig. 2 
Thus, we can make a conclusion that with the help of distance education technologies it is not only possible to put a number of routine pedagogical activities on a computer's shoulders, but to organize really qualitative, individual, differentiated teaching.

The Google Classroom service allows to avoid the organization problems of providing consumer's choice service, such as an e-mail, calendar and Drive service, and to focus on those things which a teaching establishment and a teacher must be engaged - in expanding the resources for more qualitative support of the educational process.

Google Classroom possesses a lot of opportunities: making tasks which are integrated with Google Drive; electronic collaboration on tasks, that provides a two-way communication between a student and a teacher; communication in online mode; assessment of the tasks which have been done.

In our opinion, in the Classroom it is convenient and effective to work both for a teacher and a student/pupil, as the service provides the users with a generic working device, possesses a human-engineered interface and capabilities necessary for the participants of the educational process.

\section{References}

1. Gazeykina A.I., Toporova N.V., Udartseva D.A. Primenenie servisa Google Classroom dlya organizatsii domashney rabotyi $v$ shkole [The usage of the Google Classroom service for organization of homework at school] // Aktualnyie voprosyi prepodavaniya matematiki, informatiki i informatsionnyih tehnologiy. 2019. № 4. S. 214220.

2. Demeshkevych V. Osoblyvosti vykorystannia servisiv Google $v$ diialnosti pedahohichnykh pratsivnykiv [The peculiarities of using Google services in teaching employees' activity] // Oblasna naukovo-praktychna Internet-konferentsiia «Shliakhy efektyvnoho vprovadzhennia osvitnikh tekhnolohii u navchalnykh zakladakh». Kirovohrad, 2016. Rezhym dostupu: http://konf.koippo.kr.ua/blogs/index.php/blog12/title-434.

3. Plish I.V. Vykorystannia informatsiino-komunikatsiinykh tekhnolohii upravlinnia yakistiu osvity $v$ shkolakh pryvatnoi formy vlasnosti [The usage of information and communication technologies of education quality management in privately operated schools] // Informatsiini tekhnolohii i zasoby navchannia. 2012. № 1 (27). Rezhym dostupu: http://journal.iitta.gov.ua

4. Tulina E. Kratkiy obzor osobennostey i funktsiy LMS-sistemyi ot tsifrovogo giganta Google [A brief review of peculiarities and functions of the LMS system from the digital giant Google] // Vvedenie v Google Classroom. 2014. Rezhim dostupa: https://newtonew.com/news/vvedenie-v-google-classroom 
5. Chumak L.O. Mozhlyvosti servisu Google Classroom dlia orhanizatsii navchalnoho protsesu [The Google Classroom service facilities for organization of the educational process] // Visnyk Prydniprovskoi derzhavnoi akademii budivnytstva ta arkhitektury. 2018. № 6. S. 65-70. 
DOI: 10.32370/IA_2021_09_12

\title{
Conceptual Technologies of Application of Coaching Technology in Public Administration
}

\author{
Maria Surzhyk \\ Postgraduate student \\ of the Educational and Scientific Institute of Public Administration and \\ Civil Service of Taras Shevchenko National University of Kyiv \\ Kyiv, Ukraine \\ E-mail: surzhykmaria77777@ gmail.com \\ ORCID ID https://orcid.org/0000-0002-8812-1581
}

\begin{abstract}
The article reveals the concept of coaching as an innovative technology of public administration. The technology is based on a democratic leadership style, formed by systematic thinking and a somewhat organized technique of questions, which ultimately focuses on the prospect of positive change and optimization of production relations, based on cooperation and feedback.

The global goal of coaching in public administration is defined, which provides constant updating of skills of managerial competence and successful leadership through the formation of worldview, adoption of holistic attitudes, a certain culture of communication and interaction, motivation.

The effectiveness of the use of coaching technology in public administration is substantiated.

The main further prospects of work on the research are determined. Develop scales of indicators for evaluating the effectiveness of coaching technology in public administration.
\end{abstract}

Keywords: coaching, coaching models, public administration,

Постановка проблеми в загальному вигляді та ї̈ зв'язок із важливими науковими чи практичними завданнями. У процесі зростання інтелектуалізації, виконання завдань високого рівня складності, вміння швидко адаптуватись до нових умов, мислити критично та нестандартно, володіти високим рівнем стресостійкості, комунікабельності, прагнення до навчання протягом життя $є$ принциповими вимогами, які постають перед сучасною політичною елітою у процесі державотворення. Відповідно, виникає потреба і у пошуку нових форм вдосконалення професійних навичок, компетенцій у будь-яких органах влади. Перед представниками публічної влади щоденно постає необхідність глибокого аналізу соціально-психологічних факторів управлінської діяльності. До загальних компетенцій стоїть гостра потреба додати індивідуально-психологічні особливості працівників, усвідомлення та інтерпретація ситуацій, що виникають під час реалізації державно-владних повноважень, володіння навичками конструктивної комунікації, ведення переговорів, врегулювання конфліктних ситуацій тощо. 
Компетенції необхідно розуміти як наявну здатність із погляду знань, умінь, навичок і установок, яка забезпечує реалізацію професійних завдань на високому рівні, відповідність законодавству. Науковці визначають близько 86 професійних компетенцій державних службовців. Більшість з них дотримується думки, що саме коучинг є тією технологією управління, яка дозволяє сформувати необхідні компетенції представникам органів державної влади та суттєво вплинути на ефективність діяльності в цілому.

В останнє десятиліття в Україні саме поняття і навчання коучингу, як професії, набирає все більшої популярності.

Аналіз останніх досліджень $\boldsymbol{i}$ публікацій. Питаннями результативності застосування коучингу в управлінській діяльності займалися зарубіжні науковці: Дж. Уітмор, Т. Голві, Л. Уітворт, який обгрунтував відмінність поняття коучингу від менторства та наставництва. Його дослідження продовжили Г. Кімсі-Хаус, М. Ландсберг, Д. Роберт та інші. Дослідження цих авторів містять способи реалізації коучингової взаємодії, методи застосування коучингу, окремі аспекти з оцінювання елементів коучингу. Серед вітчизняних науковців варто відзначити праці: О. Кузьміна, Н. Чухрай, В. Павлова, Л. Круглова, В. Гурієвської та інші. В. Гурієвською здійснено аналіз можливостей застосування технології коучингу в системі державного управління та підвищення кваліфікації державних службовців. Науковці висвітлили трактування поняття «коучингу», особливості його застосування, рекомендації щодо розвитку потенціалу працівників із застосуванням даного методу.

Цілі статті. Основною метою статті є охарактеризувати коучинг як технологію державного управління; обгрунтувати ефективність використання технології коучингу в публічному управлінні; охарактеризувати основні підходи застосування коучингу в світовій та Українській практиці.

\section{Виклад основного матеріалу дослідження.}

Сьогодні коучинг - звичне явище як у сфері бізнесу, де він активно використовується у сфері управління людськими ресурсами (HR-менеджмент), у роботі з бізнесконсультантами, аудиторами, фахівцями з підбору персоналу, так і в інших сферах людського життя: освіті, спорті, особистому житті тощо [5, с.8].

Основоположником коучингу вважається Джон Уітмор, який в 1992 р видав книгу "Коучинг високої ефективності" після видання якої розпочинається активне вивчення 
науковцями основних понять та підходів у застосуванні. Уітмор, як минулий спортсмен, виділив схожі підходи у досягненні результатів спортивних та професійних через ідеї Тіма Геллвея, творця теорії "Внутрішньої гри" (Inner Games), про психологічні тренуваннях спортсменів. Т. Голві у своїй книзі пише, що ідея внутрішньої гри спала йому на думку під час роботи тренером із тенісу.

Основним меседжем підходу коучингу стає усвідомлення того, що гравець (учень) вже володіє всіма природними задатками, необхідними для подолання внутрішнього супротиву та досягнення високих результатів своєї діяльності. Тому ключовим завданням коуча стає створення оптимальних умов до реалізації потенціалу підопічного.

Наразі питання глобальних та швидкісних змін ще не стояло так гостро, як сьогодні.

Бурхливий розвиток компаній доткомів (dotcom, dot-com, dot.com), що розпочався наприкінці 90-х рр.. ХХ століття) спричинив революційний перехід від звичних механізмів прийняття управлінських рішень, на які потрібно витрачати забагато часового ресурсу, що в подальшому впливає на ефективність результату та своєчасність прийняття рішень.

Відповідно до цього виникає потреба у пошуку таких нових напрямів, які будуть впливати на високу ефективність, що розуміється у зниженні перешкод та підвищення потенціалу.

Відповідно до вищезазначеної теорії Т. Голві, коучинг - це методика розкриття потенціалу особистості для максимізації власної продуктивності та ефективності. Сьогодні, це поняття розкривається при більш глибинному дослідженні. «Незважаючи на існування Міжнародної федерації коучингу (ICF) з представниками у 138 країнах, якщо переглянути слово «соасh» чи «соaching» на інтернет-сторінці Оксфордського словника, ми практично нічого не дізнаємося про те, чим саме ці люди займаються. Словник пропонує два визначення. Перше - це автобус далекого сполучення, вагон поїзду та спосіб переміщення. Друге визначення говорить про спортивний інструктаж та навчання, приватних чи додаткових уроках... В коучингу рух - все, а інструктаж та навчання - майже нічого», - говорить Джон Уітмор [6, с.24].

Нестандартність визначення терміну коучингу готує нас до того, що і сам метод змушує шукати нестандартні, креативні підходи, які виходять за рамки стандартного 
сприйняття, при цьому дотримуючись основної мети - підвищення результатів, а головним питанням залинити - як найкраще досягнути цієї мети та утримати результат.

В управлінській практиці можливості застосування коучингу надзвичайно широкі: мотивація працівників, оцінка і атестація; делегування повноважень, виконання завдання; рішення проблем, планування і контроль; питання взаємин, розвиток працівників; створення команди, групова робота.

Коучинг можна проводити до, після і під час виконання робіт. Він може проходити спонтанно, тривати одну хвилину або цілу годину. Таким чином, головний інструмент для керівника, який хоче «включити мозок» своїх співробітників, це ефективні питання $[4, \mathrm{c.4}]$.

«У більшості випадків коучинг застосовується на підприємствах в ролі унікального системного підходу до утворення корпоративної культури, методів розвитку співробітників, створення і реалізації стратегій підприємств. За винятком цього, керівники, які використовують метод коучингу як метод управління персоналом, мають можливість найбільш простіше і ефективніше утримати цінних працівників у своїй організації, тим самим знижуючи плинність кадрів. Коучинг можна застосовувати до всіх співробітників організації, але особливо він є необхідним для таких категорій, як: керівники, успішні співробітники, працівники, яким необхідні нові навички.

Безсумнівно, впровадження коучингу в організаціях повинно починатися 3 керівників та керівників підрозділів.

Коучинг для керівників вищої та середньої ланки проводиться з метою: розвитку управлінських навичок; впровадження коучингу в систему організації діяльності; залучення співробітників в роботу організації; адаптації нових керівників; розвитку системного мислення» $[4$, с.5].

Отже, коучинг - це організований, цілеспрямований процес, який орієнтований на досягнення максимально можливого результату, 3 використанням, безпосередньо, внутрішнього потенціалу людини з опорою на зовнішні умови.

Сучасний рівень розвитку держави нерозривно зв'язаний із розвитком освіти, науки, інновацій та має базуватися на інтеграції науки, психології, практики. «управлінської діяльності та розкриває зміст когнітивної і інноваційної складової державного управління [3, с.33]. 
Аналізуючи різні підходи до визначення поняття коучинг в Такий підхід до державно-управлінської діяльності потребує розглядати технології коучингу як об'єкт науки державного управління, оскільки це дає змогу вивчати і враховувати соціальнопсихологічні складові державноуправлінській діяльності ми приходимо до висновку, що коучинг в системі державного управління - це технологія, яка «базується на демократичному стилі керівництва, сформованому системному мисленні та певним чином організованій техніці запитань, що в кінцевому підсумку орієнтована на перспективу позитивних змін та оптимізацію виробничих відносин, на основі співробітництва і налагодження зворотного зв'язку. 3 іншого боку, коучинг - це компетенція менеджменту та стиль лідерства, що допомагає управлінцям реалізовувати цілі та розвиватися через взаємодію [3, с.36].

Глобальна мета коучингу в державному управлінні передбачає постійне оновлення навичок управлінської компетентності та успішного керівництва через формування світогляду, прийняття цілісних установок, певну культуру у спілкуванні та взаємодії, мотивації. Крім того, через такі глобальні аспекти формуються індивідуальні якості управлінця, що виражаються в усвідомленні власних дій та мотивів, делегуванні відповідальності, ефективності використання часового ресурсу, вдосконалення власних професійних навичок та вдосконалення інтелектуального рівня з виходом на високий рівень індивідуальної задоволеності від процесу управлінської діяльності [3, с.37].

Коучинг у системі органів державної влади - це спеціально організований процес надання допомоги керівникам, колективу (чи групі осіб) у розв'язанні проблем державноуправлінської діяльності, як послуги, що їх надають незалежні спеціалісти, та як засіб підвищення соціально-психологічної компетенції управлінців [2].

Коучинг в організаціях $\epsilon$ соціально-управлінським інструментом розвитку публічних управлінців, спрямованим на поліпшення кількісних і якісних характеристик діяльності, удосконалення професійних і особистісних навичок як керівників, так i звичайних працівників. Досвід багатьох іноземних компаній свідчить, що використання коучингу в управлінні персоналом дає змогу підвищити ефективність роботи, вдосконалити професійні та особисті навички співробітників.

Впровадження коучингу як методу управління дає змогу здійснити якісні зміни в компаніях, а саме: вивести відносини керівників з підлеглими на рівень «дорослий - 
дорослий», створити умови для щирості та відкритості всіх учасників процесу; сформувати відповідальність у співробітників за прийняті рішення i отриманий результат; надати можливість працівникам управляти своєю працею: розподіляти час, визначати необхідні ресурси, що розкриє внутрішній потенціал співробітників, створить внутрішню мотивацію, а також підвищить задоволеність від роботи; по-іншому поглянути на своє життя, підвищити його якість, позбутися внутрішніх бар'єрів, що перешкоджають досягненню цілей, і навчитися знаходити власні ресурси як керівникам, так і їх підлеглим.

В Україні на сьогодні відсутнє державне регулювання сфери коучингу, оскільки у класифікаторі професій відсутня така професія як коучер. Діяльність коучера регламентована лише вид надання інформаційних та консультаційних послуг. Наразі стоїть гостро питання підготовки таких спеціалістів в Україні. Діючі тренери-коучі, які надіють послуги відповідно рівня, мають переважно підготовку закордонних фахівців. Стримуючим фактором розвитку коучингу $є$ те, що вітчизняні бізнес-структури до дослідили достатньо глибоко специфіку діяльності таких тренерів та не залучають їх до своєї діяльності. На території України бізнес-коучерів активно залучають лише транснаціональні корпорації та компанії з іноземними інвесторами.

Висновки. Отже, коучинг в системі органів державної влади спрямований на забезпечення високих стандартів виконання завдань, створення атмосфери, яка стимулює креативність, генерацію нових ідей i $\epsilon$ надійним фундаментом інтегрованості працівників, так як проявляється через підтримку, співпрацю та партнерство, допомагає набути нових конкурентних переваг.

Перспективи подальших розвідок у даному напрямі ми вбачаємо в подальшій розробці шкали індикаторів оцінювання результативності застосування технології коучингу в публічно-управлінській діяльності.

\section{References}

1. Coaching is a tool for personal and professional development.: http://www.lifecoach.com.ua.

2. Gurievskaya, V. (2010). Technologies of psychological counseling in public authorities of Ukraine. Mechanisms of public administration. Kyiv. 
3. Gurievskaya, V. (2011). Coaching as an applied technology of public administration. Bulletin of the National Academy of Public Administration, 1, 32-39.

4. Karminska-Belobrova, M. (2018). Coaching as an innovative tool for management development in Ukraine. Bulletin of the National Technical University "Kharkiv Polytechnic Institute" (economics, 47 (1323), 3-7.

5. Nezhyns'ka, O., Tymenko, V. (2017). Basics of coaching: a textbook. Kyiv. DISA PLUS.

6. Whitmore, D. (2019). Coaching. Basic principles and practices of coaching and leadership. Moscow: Alpina Publisher.

\section{$\underline{\text { Translation of name and affiliation to author's language }}$}

\section{Марія Суржик}

аспірант Навчально-наукового інститут публічного управління та державної служби Київського національного університету імені Тараса Шевченка 
DOI: 10.32370/IA_2021_09_13

\title{
Specifics of the Concert Master's Pedagogical Activity in the Context of Trends of Modern Art Education
}

\author{
Koresandovich Natalia Mykolayivna, \\ applicant of the Kyiv National \\ University of Culture and Arts, \\ Kyiv, Ukraine
}

\begin{abstract}
The article considers the problems of pedagogical activity of the accompanist through the prism of the peculiarities of the development of art education in the first decades of the XXI century.

It is stated that the current stage in the pedagogy of concertmaster activity is characterized by the presence of formed and developed by specialists in various fields of science basic concepts, scientific and methodological principles, methods of artistic and aesthetic education of future musicians. It was found that the issue of pedagogical competence of the accompanist is one of the urgent problems, as each historical stage of development of society, forming its own guidelines for art pedagogy, makes new demands or modifies existing ones. It is noted that the problems of concertmaster activity in the context of art education at the present stage are determined by the nature and content of the conditions that characterize the life of modern society.

It is emphasized that the prospects for the development of pedagogical activities of the accompanist include educating future artists of the best artistic and aesthetic qualities, creating in the learning process conditions for comprehensive personal development, meeting professional and spiritual needs, developing their creative abilities and skills of artistic research.

The specifics of the development of modern art education involves the transformation of traditional methods and approaches to teaching in order to adapt to the requirements of modern students, as well as - to the conditions of socio-cultural space.
\end{abstract}

Key words: accompanist, pedagogical activity, modern art education, performance, music-educational process, creativity.

Актуальність дослідження. Діяльність концертмейстера (виконавська, організаційна, педагогічна) унікальна власною поліфункціональністю, що передбачає органічне поєднання амплуа концертмейстера, педагога та співучасника дії.

В умовах сучасної мистецької освіти складно уявити навчальну роботу у вокальних та інструментальних класах освітніх закладів без концертмейстера, діяльність якого стала більш складною та багатоплановою, що зумовлено посиленням вимог до професійного рівня, необхідністю розробки універсальних критеріїв професійної майстерності концертмейстера, які включають ряд необхідних особистісних якостей.

Теоретико-практичний дискурс педагогічної діяльності концертмейстера у цьому контексті зазнає відчутних змін, що зумовлює актуальність дослідження даного аспекту проблематики концертмейстерства. 
Аналіз публікацій. Історія концертмейстерства як виду музичної практики нараховує кілька століть, практично з часів середньовічних мандруючих музикантів менестрелів, жонглерів та шпільманів. Проте і на сучасному етапі розвитку гуманітарного знання, досліджень, що надавали б цілісне уявлення про базові принципи та специфічні особливості концертмейстерської діяльності недостатньо. Це пояснюється тривалим культивуванням даного виду музичної діяльності в галузі аматорського музикування та позиціюванням його супутнім видом занять в творчій діяльності виконавця-професіонала. Водночас аналіз останніх досліджень та публікацій засвідчує активізацію наукового інтересу до проблематики педагогічної майстерності концертмейстера. Наприклад, О. Щербінін у науковій публікації «Професійна діяльність музиканта-педагога: сучасні вимоги та критерії оцінювання» [11] обгрунтовує вимоги до фахівців музично-педагогічної галузі, здійснюючи спробу виявити специфіку оперування відповідними спробами передачі власного творчого досвіду; О. Переверзєва в статті «Педагогічні аспекти професійної діяльності концертмейстера у загальнокультурному та музично-естетичному розвитку майбутнього вчителя музичного мистецтва» [9] аналізує професійну діяльність концертмейстера відповідно до специфіки системи закладів вищої освіти, акцентуючи на дослідженні доцільності трансформацій та доповнень з метою удосконалення професійної підготовки концертмейстерів в умовах спеціальних освітніх закладів; В. Зорін у публікації «Педагогічна майстерність піаністаконцертмейстера» [4] висвітлює методологію діяльності піаніста-концертмейстера; О. Умрихіна та А. Подолян у науковій розвідці «Роль піаніста-концертмейстера в педагогічній освіті» [10] розглядають педагогічний аспект діяльності концертмейстера в контексті успішного виховання педагога-музиканта; Р. Гургула та I. Сфремова в публікації «Педагогічний аспект підготовки майбутнього піаніста-концертмейстера» [3] зосереджують увагу на вивченні психолого-педагогічної площини навчання піаністівконцертмейстерів у педагогічному коледжі та ін.

У даному дослідженні педагогічна діяльність концертмейстера розглядається крізь призму особливостей та тенденцій розвитку сучасної мистецької освіти.

Мета статті - виявити особливості педагогічної діяльності концертмейстера в контексті особливостей розвитку мистецької освіти в перші десятиліття XXI ст. 
Виклад основного матеріалу. В сучасному науковому вітчизняному та закордонному вимірі розуміння та осмислення концертмейстерства суттєво відрізняються, що зумовлено різницею термінології - «concertmaster» в більшості країн трактується як «перша скрипка в оркестрі», натомість педагог, який допомагає музикантам у процесі навчання вивчати партії, а також акомпанує інструменталістам і вокалістам - терміном «ріanist» [3, с. 26].

Головною особливістю професійної діяльності концертмейстера є комплекс його виконавських та тактико-психологічних вмінь, що окрім вміння чути власне виконання, передбачає знання партії партнера та навички органічно реагувати на ситуативний контекст з метою демонстрації слухачам цілісної виконавської інтерпретації [7, с. 128]; концертмейстер має чітко передавати головні параметри стилю музичного твору, співвідноситись з індивідуальністю соліста та явити власне обличчя в сумарному виконавському результаті.

Концертмейстерство, як творча багатопрофільна діяльність піаніста, включає в себе базові константні компоненти - власне адресант, музикант-художник широкої кваліфікації та його спеціальні ансамблеві навички, психологічні якості, педагогічні та організаційні здібності.

Професійна підготовка кадрів для повноцінної в творчому відношенні діяльності в усіх галузях музичного мистецтва, виховання естетично розвинутих та самостійно мислячих музикантів, ставить в галузі музичної освіти серйозні завдання як перед педагогами, так і перед концертмейстерами. Відповідно, зростають вимоги до професійної майстерності, що включає не лише високий в художньому та технічному відношенні рівень володіння виконавськими та психологічними навичками і прийомами, але й педагогічними компетенціями, що передбачає знання педагогічних аспектів професійної діяльності, специфіку мистецької педагогіки та вміння застосовувати власні знання на практиці.

Функції концертмейстера мають педагогічний характер, оскільки участь у виборі педагогом програми i спільне вивчення музичного твору сприяють розвитку музикальності та індивідуальності соліста. Відповідно педагогічний бік діяльності піаніста вимагає використання власного концертмейстерського досвіду, зокрема виразного виконання, що сприяє сприйняттю форми, метроритму, ладу та інших засобів 
художньої виразності, а також ряду спеціальних умінь та навичок в галузі суміжних виконавських дисциплін, знань в галузі психології та педагогіки. Л. Баренбойм наголошує, що концертмейстер має бути наділений відчуттям професійної відповідальності за художній результат, культурою спілкування та проявляти педагогічний такт, витримку, оптимізм у вирішенні поставлених завдань [1, с. 27].

Діяльність концертмейстера передбачає співпрацю 3 представниками різних художніх спеціальностей (наприклад, інструменталістами та вокалістами, хоровими колективами, вокальними, інструментальними i хореографічними ансамблями). Відповідно, він має бути музикантом-універсалом, який зазвичай виконує і педагогічні функції.

Педагогічні аспекти діяльності концертмейстера базуються на всебічному аналізі твору, визначенні стилістичних особливостей, технічних труднощів та виконавських засобів сценічної виразності.

На думку В. Калініної, професійний концертмейстер - важлива ланка в складному ланцюгу музично-навчального процесу, а суть його роботи полягає в забезпеченні художньої творчості партнера або партнерів засобами музичного супроводу, що доцільно розглядати як один зі способів педагогічної діяльності [5, с. 8].

Основою змісту та структури творчої діяльності концертмейстера є педагогічна концепція розвиваючого навчання, відповідно до якої робота над удосконаленням професійних музично-виконавських знань, навичок та вмінь партнера або партнерів знаходиться в тісному зв'язку з універсальним розвитком індивіда, розширенням його художніх знань та загальнокультурної ерудиції, активізацією творчих та пізнавальних можливостей.

В. Кононено акцентує на тому, що сама природа концертмейстерського мистецтва призначена для виховання музичної культури майбутніх вчителів музики, як частини всієї їх духовної культури, в єдності з педагогічною технологією забезпечення цього процесу [6, с. 3].

Педагогічний аспект роботи концертмейстера складається 3 гностичного, конструктивного, комунікативного та організаційного компонентів. Концертмейстер, який створює атмосферу спільного пошуку, співтворчості, що допомагає учню розширити власні можливості, повинен володіти мастерністю педагогічної імпровізації. 
Дослідники наголошують, що фундаментальною основою навчально-виховного процесу, з якого походять всі його аспекти, повинно виступати розуміння педагогічної спрямованості професії концертмейстер як виховання спільних способів музичнохудожньої діяльності. Зокрема, в навчальному курсі «Концертмейстерський клас» корінне протиріччя художньої освіти в цілому між призначенням та змістом мистецтва i методами його вивчення та викладання конкретизується в протиріччі між сутністю «мистецтва концертмейстера» як фундаменту художнього розвитку педагога-музиканта та організацією цього процесу з поцій формування лише професійних знань, вмінь та навичок. Відповідно комплекс «специфічних» концертмейстерських навичок на вмінь, що традиційно виділяється на практиці, має змінити свій статус і бути переосмислений як універсальна «технологія» музичного виконавства [6, с. 19].

Водночас теоретики та практики концертмейстерської діяльності констатують, що жоден навчальний заклад не в змозі сформувати «закінченого концертмейстерапрофесіонала» [2, с. 25], а лише дає принципи, базові навички та знання в галузі концертмейстерства, які надалі індивід удосконалює самостійно протягом всієї професійної кар'єри.

Однією з тенденцій сучасної музичної педагогіки $є$ зміна визначення статусу концертмейстера як педагога-репетитора або, відповідно до західної термінології, «коуч». Наприклад, Л. Курицькою вперше здійснено спробу адаптування коучінгового підходу, що передбачає, окрім виконання традиційних функцій, пов'язаних із художньовиконавськими компетенціями музиканта, виконання психологічних, організаційних та консультативних функцій, зокрема:

- формування мотивації учня та його психологічної готовності до концерту;

- підтримка в процес подолання труднощів;

- емоційна підтримка та емпатія;

- планування та координація виконання етапів роботи;

- оцінка професійних можливостей соліста та їх розвиток;

- часткове виконання функції педагога зі спеціальності, диригента, режисера та ін.

Теоретик і практик концертмейстерської діяльності стверджує, що в музичній освіті коучінг може розумітися як унікальне ставлення до студента, з метою його 
підтримки, спрямоване на самостійну постановку цілей та пошук способів їх досягнення, яке максимально задіює його музичні та загальні здібності, що реалізують його професійно-технічний та творчий потенціал, сприяють ефективності та особистісному зростанню [8, с. 266].

Однією з актуальних тенденцій мистецької освіти на початку третього десятиліття XXI ст. є дистанційне навчання, а його активне використання як альтернативного традиційному в умовах загрози поширення коронавірусної інфекції $\epsilon$ не лише виправданим, а й необхідним. У зв’язку з цим виникла гостра проблема пошуку нових технологій навчання та їх використання в діяльності концертмейстерів. Наприклад, дієвим способом допомоги майбутньому музиканту в процесі вивчення твору є запис аудіофайлу партії супроводу.

Перспективами подальшого дослідження означеної проблематики $є$ аналіз педагогічної діяльності концертмейстера в контексті особливостей його підготовки в закладах музичної освіти та власне його участі в навчальному процесі як викладача в закладах мистецької освіти України.

Висновки. Сучасний етап у педагогіці концертмейсерської діяльності характеризується наявністю сформованих та розроблених спеціалістами різних напрямів науки основних понять, науково-методичних принципів, методик системи художньоестетичного виховання майбутніх музикантів. Дослідження виявило, що проблематика педагогічної компетенції концертмейстера належить до числа актуальних проблем, оскільки кожен історичний етап розвитку суспільства, формуючи власні орієнтири мистецької педагогіки, висуває нові вимоги або модифікує чинні. Відповідно специфіка розвитку сучасної мистецької освіти передбачає трансформацію традиційних методів та підходів викладання з метою адаптування до вимог сучасних студентів, а також - до умов соціокультурного простору.

Проблеми концертмейстерської діяльності в контексті мистецької освіти на сучасному етапі визначаються характером та змістом умов, що характеризують життя сучасного суспільства. Перспективи розвитку педагогічної діяльності концертмейстера спрямовані на виховання у майбутніх митців найкращих художньо-естетичних якостей, створення в процесі навчання умов для всебічного розвитку особистості, задоволення 
професійних та духовних потреб, розвиток творчих здібностей та навичок художньодослідницької діяльності.

\section{References}

1. Barenboim, L.A. (1974). Musical pedagogy and performance. Leningrad: Music.

2. Bobrova, E. V., Buslova, E. V., Akhlestina, A. Yu. (2020). Actual problems of the professional activity of an accompanist in the context of modern music education. Culture and art in the modern educational space: Materials of the IV All-Russian scientific and practical conference (with international participation), dedicated to the 60th anniversary of the founding of music, pedagogical and art education at Kostroma State University. Resp. ed. and comp. T.V. Ludanov, ed. and comp. N. E. Musinova, pp. 21-27.

3. Gurgula, R. I., Efremova, I. M. (2021). Pedagogical aspect of training future pianistaccompanist. Pedagogy of formation of creative personality in higher and general education schools, no. 75, pp. 26-31. DOI https://doi.org/10.32840/1992-5786.2021.75-1.5.

4. Zorin, V. V. (2019). Pedagogical skills of pianist-accompanist. Gilea: scientific bulletin, Issue 145 (2), pp. 72-75.

5. Kalinina, V. D. (2015). Basic components and professional specification in the creative activity of the accompanist-pianist. Abstract of Ph.D. Saratov : Saratov State Conservatory named after L. V. Sobinov.

6. Kononenko, V. A. (2008). The art of accompanist in professional education of a music teacher. Abstract of Ph.D. Moscow : RAO "Institute of Art Education".

7. Kravets, M. V, Borisova, E. N. (2017). Psychological and pedagogical aspect of training a future pianist-accompanist in the context of a professional communicative environment. Scientific-methodical electronic journal "Concept", no. 3, pp. 127-133.

8. Kuritskaya, L. V. (2019). Coaching approach in working with students of the accompanist class. Manuscript. Tambov: Diploma, Vol. 12, Issue 11, pp. 265-269.

9. Pereverzeva, O. (2019). Pedagogical aspects of the professional activity of the accompanist in the general cultural and musical-aesthetic development of the future teacher of musical art. Pedagogical education: theory and practice, Issue 27, pp. 226-230.

10. Umrikhina, O., Podolyan, A. (2017). The role of pianist-accompanist in pedagogical education. Collection of scientific works of UDPU named after Pavel Tychyna, Issue 2, Part 2, pp. 286-295.

11. Shcherbinin, O. M. (2018). Professional activity of a musician-teacher: modern requirements and evaluation criteria. Scientific notes of NDU named after M. Gogol, no. 1, pp. $85-89$.

\section{Translation of the References to the Author's Language}

\section{Список використаних джерел}

1. Баренбойм Л.А. Музыкальная педагогика и исполнительство. Ленинград : Музыка, 1974. 335 с. 
2. Боброва Э. В., Буслова Е. В., Ахлестина А. Ю. Актуальные проблемы профессиональной деятельности концертмейстера в условиях современного музыкального образования. Культура и искусство в современном образовательном пространстве : Материалы IV Всероссийской научно-практической конференции (с международным участием), посвященной 60-летию основания музыкальнопедагогического и художественного образования в Костромском государственном университете. Отв. ред. и сост. Т.В. Луданова, ред. и сост. Н Е. Мусинова. 2020. С.21-27.

3. Гургула Р. I., Єфремова I. М. Педагогічний аспект підготовки майбутнього піаніста-концертмейстера. Педагогіка формування творчої особистості у вищій i загальноосвітній школах. 2021. № 75. C. 26-31. DOI https://doi.org/10.32840/19925786.2021.75-1.5.

4. Зорін В. В. Педагогічна майстерність піаніста-концертмейстера. Гілея: науковий вісник. 2019. Вип. 145(2). С. 72-75.

5. Калинина В. Д. Базовые компоненты и профессиональная спецификация в творческой деятельности концертмейстера-пианиста : автореферат дис. канд искусствоведения : 17.00.02 / Саратовская государственная консерватория имени Л. В. Собинова. Саратов, 2015. 15 c.

6. Кононенко В. А. Искусство концертмейстера в профессиональном образовании учителя музыки : автореферат дис. канд. педагогических наук : 13.00.08 / РАО «Институт художественного образования». Москва, 2008. 22 с.

7. Кравец М. В., Борисова Е. Н. Психолого-педагогический аспект подготовки будущего пианиста-концертмейстера в контексте профессиональной коммуникативной среды. Научно-методический электронный журнал «Концепт». 2017. № 3. С. 127-133.

8. Курицкая Л. В. Коучинговый подход в работе со студентами концертмейстерского класса. Манускрипт. Тамбов : Грамота, 2019. Т. 12. Вып. 11. С. 265-269.

9. Переверзєва О. Педагогічні аспекти професійної діяльності концертмейстера у загальнокультурному та музично-естетичному розвитку майбутнього вчителя музичного мистецтва. Педагогічна освіта: теорія і практика : збірник наукових праць. 2019. Вип. 27. C. $226-230$.

10. Умрихіна О., Подолян А. Роль піаніста-концертмейстера в педагогічній освіті. Збірник наукових праць УДПУ імені Павла Тичини / гол.ред. Мартинюк М.Т. Умань : ВПЦ «Візаві», 2017. Вип.2, Ч.2. С. 286-295.

11. Щербінін О. М. Професійна діяльність музиканта-педагога: сучасні вимоги та критерії оцінювання. Наукові записки НДУ ім. М. Гоголя. 2018. № 1. С. 85-89. 
DOI: 10.32370/IA_2021_09_14

\title{
Organization of Experimental Work on the Formation of Musical and Aesthetic Competence of Adolescents in Out-Of-School Art Education
}

\author{
Liao Bin \\ Postgraduate student \\ Dragomanov National Pedagogical University (Kyiv, Ukraine)
}

\begin{abstract}
The article emphasizes that the state of modern art education in Ukraine and China requires the introduction into the practice of music education of students of out-of-school educational institutions of new methods aimed at forming their musical and aesthetic competence. Presented step-by-step method covers piano preparation of teenage students in two planes-performing and art-theoretical and provides for the presence of three stages: organizational-orientational, intellectual-deepening and creative-enriching. The main purpose of the first organizational and orientation stage of education was to acquire in adolescents a positive motivation for musical and aesthetic activities and the expansion of the thesaurus of musical knowledge.

The second (intellectually-deepening) stage was aimed at theoretical and practical development of musical knowledge in order to form in adolescents musical and aesthetic competence, filling musical and intonation vocabulary, expanding musical and aesthetic worldview, activating emotional impressions, comparing their own experiences with artistic content of piece of music, accumulation of musical thesaurus and musical performance experience. The third (creative-enriching) stage was aimed at developing the ability to genre-style embodiment of interpretive ideas, creative evaluation of musical phenomena on the basis of the system of values adopted in the art of music.
\end{abstract}

Key words: musical-aesthetic-competence, out-of-school art institutions, piano training, teenagers, piano teaching methods.

Актуальність. На сучасному етапі реалізації освітньої стратегії особливої ваги набуває питання формування музично-естетичної компетентності підлітків у закладах позашкільної мистецької освіти. Така тенденція простежується не тільки в Україні, а і в Китаї. Державну політику у сфері позашкільної освіти у цих країнах визначають Державна національна програма «Освіта» (Україна XXI століття), «Закон України «Про освіту» (2017p., у новій редакції з 16.01.2020p.), «Про позашкільну освіту», Концепція «Нової української школи» (2016р.), «Стратегія розвитку освіти в Китаї у XXI столітті», «Реформи розвитку базової освіти КНР». У цих документах позашкільна освіта розглядається як цілісна міжгалузева і багаторівнева система для забезпечення розвитку здібностей та таланту обдарованих дітей та молоді.

Зокрема відомий педагог О. Бруднов зазначає наступне: «Відмінність мережі установ позашкільної освіти дітей від інших освітніх установ полягає в тому, що в них дитина проходить зовсім інший освітній шлях... Ми не тільки даємо їй інформацію, а 
включаємо у процес, що сприяє освоєнню різних галузей людської діяльності, знання, дозволяє набувати вміння та навички, вдивлятися в майстерність своїх рук, в досконалість свого педагога, і на основі цього робити власний вибір і визначати шляхи розвитку» [1, с. 26-32].

Теоретико-методологічна складова музично-естетичного розвитку учнів підліткового віку представлена у дослідженнях Н. Миропольської, Г. Падалки, Л. Паньків, О. Ростовського, О. Рудницької, Л. Хлєбнікової, Г. Шевченко, О. Щолокової. Частково означена проблема знайшла відображення у наукових розвідках українських (Г. Бриль, В. Мішедченко, О. Сбітнєвої, І. Слятіної) та китайських (Лі Джуйцін, Тженг Чен-Лі, Тун Даоцзинь, Чжоу Гуанрен) науковців.

Водночас, огляд наукової літератури засвідчив, що проблема формування музично-естетичної компетентності підлітків у закладах позашкільної спеціалізованої мистецької освіти ще не стала предметом цілісного дослідження.

Mema cmammi - презентувати поетапну методику формування музичноестетичної компетентності підлітків у закладах позашкільної мистецької освіти.

Виклад основного матеріалу. Авторська експериментальна методика передбачала цілеспрямоване та поетапне формування визначених на попередньому етапі дослідження компонентів музично-естетичної компетентності (мотиваційно-цільового, комунікативно-емоційного, ціннісно-інтелектуального). Вона реалізувалася на основі таких принципів: ідеального та еталонного в музичному мистецтві, культурної самоідентифікації, міжкультурного діалогу, творчого універсалізму, а також педагогічних умов: створення у закладах позашкільної мистецької освіти художньоестетичного середовища, розвитку у підлітків здатності до повноцінного сприйняття музичних творів, постійного оновлення музично-інтонаційного словника, вивчення в процесі навчання фортепіанної музики для дітей та юнацтва, оволодіння підлітками навичками художньої інтерпретації музичних творів та формування музичноестетичного світогляду.

Формування музично-естетичної компетентності підлітків здійснювалось за допомогою таких музично-естетичних форм навчання: усні (роз'яснення змісту музичного твору); практичні (порівняння з іншими творами); творчі (демонстрація окремих уривків 3 творів, інтерпретація музичних творів); проблемно-пошукові 
(створення проблемних ситуацій під час фортепіанних занять); самостійного сприйняття, вивчення та інтерпретування мистецьких творів.

Проведення методики формування музично-естетичної компетентності підлітків здійснювалося впродовж трьох етапів: організаційно-орієнтаційного, інтелектуальнопоглиблюючого, творчо-збагачувального, кожен з яких мав свою мету, завдання, засоби педагогічного впливу та спеціально розроблене методичне забезпечення. Етапи було сплановано таким чином, аби на кожному з них відбувалось поступове формування усіх компонентів музично-естетичної компетентності. При цьому ми враховували, що це має бути безперервним процесом музично-естетичного саморозвитку і самовдосконалення.

Так, на першому (організаційно-орієнтаційному) етапі увага зосереджувалася на формуванні позитивної мотивації підлітків до музично-естетичної діяльності та розширенні тезаурусу музичних знань. Проведення даного етапу здійснювалось на основі міждисциплінарного та гедоністичного підходів, 3 урахуванням принципів культурної самоідентифікації та міжкультурного діалогу, вікових особливостей учнів підліткового віку, а також реалізації такої педагогічної умови як створення в закладах позашкільної мистецької освіти художньо-естетичного середовища, розвитку здатності до повноцінного сприйняття музичних творів та розвиток музично-естетичного світогляду учнів. Завдання цьвого етаnу полягали в окресленні провідних напрямів фортепіанного розвитку учнів на період експерименту, формуванні зацікавленості музичним мистецтвом, установки на естетичне сприймання дійсності, активізації емоційно-чуттєвої сфери підлітків. Для вирішення поставлених завдань використовувалися такі форми роботи як пояснення змісту музичного твору і порівняння з іншими творами, а також ігрові, пізнавальні, дискусійні методи.

Загальновідомо, що сформована музично-естетична компетентність підлітків включає розвинуту здатність сприймати твори мистецтва. Це стосується, в першу чергу, їх образного змісту, а також виражає прагнення учнів усвідомити переживання, втілені композитором, художником, балетмейстером у своїх творах, отримати насолоду від досконалості їх форм. При цьому, здатність до сприйняття і розуміння мистецтва змінюється разом з естетичним зростанням учнів.

3 метою розвитку здатності до сприйняття творів різних видів мистецтв учням експериментальної групи було запропоновано проблемно-пізнавальні завдання: 
прослухати, оглянути та проаналізувати низку живописних, скульптурних та архітектурних творів.

Для його виконання були використані методи художньо-естетичного наведення та естетичного оцінювання, відібрані живописні твори різних жанрів: пейзаж (О. Кокошка «Буревій», Ма Юань «Гірською стежкою по весні», Лі Кежань «Кленовий ліс у Данься»); портрет (К. Малевич «Квіткарка», О. Кричевський «Сім’я», Чжао Менфу «Монах у червоному одязі», Ло Чжунлі «Батько»; історичний живопис (Ф. Красицький «Гість із Запоріжжя», О. Мурашко «Похорон кошового», І. Рєпін «Козаки пишуть письмо турецькому султану»; народне мистецтво (І. Падалка «Фотограф на селі», I. Марчук «Очі дивляться нам услід», М. Приймаченко «Горіховий звір».

При сприйнятті творів живопису учням необхідно було дотримуватися таких порад: дивлячись на картину, не обмежуватися лише спогляданням; зрозуміти, яку роль виконують композиція і колорит, без яких вона є тільки натуралістичним переказом дійсності; дивлячись на пейзаж, не задовольнятися лише тим, що зображено, адже метою художника було не сліпе ії копіювання, а передача почуттів.

Під час сприйняття скульптурних зразків (В. Архипенко «Жінка, що йде», В. Татлін «Конструкція у блакитному й жовтому», Р. Петрук «Мойсей», Т. Бертель «Меркурій із сопілкою», А. Канова «Амур і Психея») увага учнів приверталась на особливості та відмінності скульптури минулих віків та сучасності; на загальну структуру, фактуру, і матеріал, на новації і творчі пошуки кожного митця.

В якості архітектурних були наведені приклади будівель у стилі класицизму в різних містах України: Палац Розумовського в Батурині (Ч. Камерон і А. Рінальді), головний корпус Київського національного університету імені Т. Шевченка (В. Беретті), Палац Потоцьких в Одесі (Ф. Буффо). Це дало можливість прослідкувати особливості розвитку мистецтва архітектури епохи класицизму. Під час ознайомлення з цими спорудами учні з'ясовували, що мистецтво класицизму - це ідеал гармонії, довершеності й досконалості. Цей стиль заснований на принципах античності і керується його правилами та канонами; класицизм прагнув виразити піднесені, героїчні й моральні ідеали, створити ясні та органічні образи. Для будівель, створених у цьому художньому стилі, характерні масивні і досить стійкі конструктивні елементи прямокутних і арочних форм. 
Виконання цих завдань супроводжувалося інтерактивними іграми («Склади літературне оповідання», «Уяви, що ти митець», «Інтерв’ю» тощо), а також пізнавальнопошуковими завданнями: знайти подібності в творах одного жанру, виявити особливості архітектурного стилю або живописного жанру, відзначити основні виражальні засоби в образотворчому мистецтві, скульптурі та архітектурі, дати назву представленій картині або скульптурі.

Оцінювання вправ здійснювалось за 12-ти бальною шкалою за такими вимогами: уміння сприймати твір глибоко, цілісно, з урахування всіх складових художньої мови, комплексне сприйняття твору, враховуючи його контекст і підтекст, емоційна реакція на сприйнятий твір, співвідношення інтелектуального і чуттєвого в процесі сприйняття творів. І хоча всі відповіді були індивідуальними, нам вдалося систематизувати найбільш переконливі думки і судження підлітків.

Другий напрямок першого етапу передбачав зацікавленість учнів музичним мистецтвом в процесі фортепіанного навчання. Він спрямовувався на теоретичне та практичне освоєння музичних знань з метою формування у підлітків музично-естетичної компетентності, наповнення музично-інтонаційного словника, розширення музичноестетичного світогляду і активізації емоційних вражень.

Учням пропонувалося оволодіти методами ескізного ознайомлення з музичними творами та читання 3 аркуша. Для роботи за цими методами було розроблено репертуарний список, до якого були включені нескладні для виконання, але різнобічні за змістом та жанром твори, наприклад, І. Шамо «Скерцо», В. Кирейко «Колискова», В. Барвінський «Думка». На індивідуальних заняттях педагог методом музичноестетичного навіювання направляв увагу учнів на особливості композиторського стилю, емоційно-образного змісту, засоби художньої виразності, і головне, - на виявлення музично-естетичної цінності даних творів.

Завдяки проведеній роботі на цьому етапі дослідження було визначено основні напрями формування музично-естетичної компетентності підлітків, значно підвищено рівень їх комунікативно-емоційної взаємодії та пізнавальної мотивації, закладено основи ціннісного ставлення до музично-естетичної діяльності та перспективного бачення процесу власного фортепіанного зростання. 
Другий етап (інтелектуально-поглиблюючий) спрямовувався на теоретичне та практичне освоєння музичних знань 3 метою формування у підлітків музичноестетичної компетентності, наповнення музично-інтонаційного словника, розширення музично-естетичного світогляду, активізації емоційних вражень, співставлення власних переживань 3 художньо-образним змістом твору, накопичення музичного тезаурусу та музично-виконавського досвіду. Цей етап грунтувався на гедоністичному, компетентнісном та жанрово-стильовому підходах з орієнтацію на принципи ідеального та еталонного в музичному мистецтві, міжкультурного діалогу, естетизації змісту навчання; при цьому реалізовувалися такі педагогічні умови: постійного оновлення музично-інтонаційного словника підлітків в процесі фортепіанних заняття, розвиток здатності до повноцінного сприйняття музичних творів та використання фортепіанної музики для дітей та юнацтва. Завдання даного етапу передбачали розвиток емоційної чутливості, оволодіння навичками комунікативної взаємодії, стимулювання прагнень на оволодіння художньою інформацією. Було використано методи музично-естетичного узагальнення та музично-естетичного порівняння; передбачено використання творчопізнавальних завдань.

Завдання даного етапу передбачали розвиток емоційної чутливості, оволодіння навичками комунікативної взаємодії, стимулювання прагнень на оволодіння художньою інформацією. Враховуючи, що формування музично-естетичної компетентності підлітків передбачає i художньо-виконавський розвиток, до експериментальної методики були включені цікаві та різнохарактерні твори, використовувалися методи музично-естетичного узагальнення та музично-естетичного порівняння також передбачалося використання творчо-пізнавальних завдань.

Наприклад, знайомство учнів $з$ двома цікавими фортепіанними циклами сучасних композиторів В. Сильвестрова «Кітч-музика для фортепіано» і Чжан Чжао «Китайська фортепіанна мрія» відбувалося на груповому занятті в класі одного викладача. Так, під час знайомства з першим циклом учні дізналися, що він складається 3 п’яти частин, в яких провідною творчою настановою для автора стала медитативність - спосіб світовідчуття, зафіксований в музичному тексті, який в даному контексті став механізмом смислового творення міського романсу. В процесі обговорення підліткам було наголошено, що В.Сильвестров $є$ одним із найбільш своєрідних сучасних 
українських композиторів, світогляд якого дослідники відзначають як переважно ліричний [2, с. 17-19].

Натомість композитор Чжан Чжао у циклі «Китайська фортепіанна мрія» взяв за мету представити світу художню цінність китайської фортепіанної музики. Сенс своєї праці він виразив словами: «У моєму розумінні китайська мрія - це мрія нації, водночас, - це мрія кожного китайця, і це наша музична мрія як музичних працівників» [4, с. 3234]. Під час знайомства $з$ циклом увага учнів зверталась на цікаву драматургію твору, а саме, цикл «Китайська фортепіанна мрія» складається 3 чотирьох частин, в яких «переплітаються час і простір». У кожній з них фортепіано імітує звучання дзвонів або курантів, тим самим символізуючи відлік часу. Бій курантів відзначає епохи китайської цивілізації від давнини до сучасності. Так, у першій частині відображене героїчне минуле китайського народу, а друга - це нагадування про велике потрясіння нації від західної промислової революції. Третій удар дзвону символізує тріумф революції, повстання народу проти несправедливості і відродження національної економіки. Четвертий удар - це майбутнє Китаю, його процвітання і культурне відродження, здійснення китайської мрії (зайняти провідне місце в сучасному світі).

Наступним було ескізне ознайомлення та самостійна робота над згаданими творами. На прослуховуванні у класі використовувався метод виконавської демонстрації, тобто учні експериментальної групи представляли свої інтерпретаційні задуми й анотації, а потім їх обговорювали та відстоювали власну виконавську позицію. Після завершення прослуховування учні перейшли до виконання нового проблемнопошукового завдання: відібрати та систематизувати за відповідним характером твори інших композиторів з власного репертуару та репертуару своїх товаришів. Результати виконання цього завдання засвідчили інтерес підлітків до пошуку нових творів. Вони відзначили, що такий пошук завжди є цікавим, оскільки допомагає їм ознайомитись із новими творами.

Третій (творчо-збагачувальний) етап спрямовувався на розвиток здатності до жанрово-стильового втілення інтерпретаційних задумів, творчого оцінювання музичних явищ на основі прийнятої у суспільстві системи цінностей; вироблення вмінь емоційновольової регуляції концертних виступів, розвиток інтелекту і музикальності. Цей етап грунтувався на акмеологічному, гедоністичному та компетентісному підходах із 
використанням принципів творчого універсалізму та міжкультурного діалогу, ідеального та еталонного в музичному мистецтві.

Під час його проведення реалізовувалися такі педагогічні умови: постійного оновлення музично-інтонаційного словника, розвиток музично-естетичного світогляду, оволодіння уміннями художньої інтерпретації музичних творів. Ми прагнули адаптувати підлітків до концертних виступів, що вимагало виховання емоційно-вольових якостей, вміння тримати себе на сцені, спрямовуючи увагу на виконання творчих завдань. Враховуючи набутий на попередніх етапах музично-естетичний досвід підлітків, активно використовувалися дискусійні та творчі, ілюстративні та сюжетні методи, проблемнопошукові форми навчання.

Важливим напрямком у оновленні музично-інтонаційного словника підлітків вважали вивчення поліфонічних творів. Зазначимо, що цей феномен як атрибут художнього діалогу представлений в музичному мистецтві, літературі, поезії, драматургії, архітектурі, живописі. В музичній педагогіці поліфонія застосовується в процесі навчання учнів різного шкільного віку, при цьому виконання поліфонічних творів є одним із найскладніших завдань фортепіанного навчання. Поряд із розвитком різних виконавських умінь (художньо-технічних, імпровізаційних, темпо-ритмічних, педалізації та тембрального забарвлення, музично-виконавської артикуляції) уміння виконувати поліфонічні твори стають важливою складовою музично-естетичної компетенції підлітків. Відтак із учнями експериментальної групи була проведена бесіда «Особливості поліфонічної музики», в процесі якої розглядались та демонструвались поліфонічні твори Й. Баха, Й. Брамса, П. Хіндеміта, М. Регера, Д. Шостаковича та відомого китайського композитора Хуан Цзи. У процесі бесіди було відзначено поліфонічний доробок українського композитора В. Бібіка, зокрема його цикл «24 прелюдії і фуги», про який Л. Грабовський писав: «Думаю, що такого фундаментального, значного, оригінального, багато в чому новаторського циклу прелюдій i фуг після П. Хіндеміта і Д. Шостаковича ще не було написано» [7].

Після ознайомлення із значною кількістю поліфонічних творів підлітки прийшли до висновку, що їх виконання потребує артистичної зрілості та широти світогляду. Глибина та краса музичної думки композитора вимагає від виконавця широких знань і всебічних навичок, тонкого музичного смаку і багатого інтелекту. Отримані дані 
наприкінці третього етапу засвідчили значне підвищення рівня всіх компонентів музично-естетичної компетентності. Зокрема, підвищилась мотивація до фортепіанного навчання, вони почали активніше набувати знання та уміння 3 метою яскравого та емоційного виконання музичних творів. Підлітки навчилися адаптуватися до власних концертних виступів, тримати себе на сцені, спрямовуючи увагу на виконання творчих завдань.

Висновки. Отже, результатом навчання підлітків у фортепіанних класах закладів позашкільної мистецької освіти стала позитивна динаміка сформованості музичноестетичної компетентності як цілісного та відносно стійкого особистісного утворення, що містить комплекс взаємопов'язаних мотиваційно-цільових, комунікативноемоційних, ціннісно-інтелектуальних детермінант, котрі забезпечують безперервний музично-естетичний розвиток та виконавське зростання підлітків.

\section{References}

1. Brudnov A.K. Sistema vospitaniya i dopolnitel'nogo obrazovaniya detey: ot idey do vnedreniya [System of upbringing and additional education of children: from ideas to implementation]. Pedagogika. 1999. No. 6. Pp. 26-32.

2. Zhalyeyko D.M. Try pohlyady ta try prochytannya: porivnyal'nyy analiz vykonavs'kykh versiy fortepiannoho tsyklu «Kitch-muzyka»V. Syl'vestrova [Three views and three readings: a comparative analysis of the performance versions of the piano cycle "Kitsch Music" by V. Silvestrov]. Visnyk KHDADM. 2014. No. 8. Pp. 16-21.

3. Mystets'ka osvita u vymirakh suchasnosti: problemy teoriyi ta praktyky. Naukova shkola Ol'hy Pylypivny Shcholokovoyi [Art education in the dimensions of modernity: problems of theory and practice. Scientific school of Olga Pylypivna Shcholokova] : [monohrafiya] / red.: O.M. Polatayko; Nats. ped. un-t im. M.P. Drahomanova. Dnipropetrovs'k : Adverta, 2014. $305 \mathrm{p}$.

4. Ni In. Sozdaniye «Kitayskoy mechty» dlya fortepiano. Na puti k utverzhdeniyu roli vostochnoy tsivilizatsii. Interv'yu s Chzhan Chzhao [Creation of "The Chinese Dream" for piano. Towards an assertion of the role of Eastern civilization. Interview with Zhang Zhao ]. Muzyka. 2015. No. 3. Pp. 32-34.

5. Pet'ko L.V. Linhvosotsiokul'turnyy pidkhid u vyvchenni amerykans'koyi novorichnoyi pisni «Jingle Bells» [Linguo-sociocultural approach in the study of American New Year's song "Jingle Bells"]. Topical issues of pedagogy: Collective monograph. Editoria di Modena, Roma, Italy. 2019. Pp. 31-58.

6. Pet'ko L.V. Stymulyuvannya tvorchykh zdibnostey pidlitkiv zasobamy vtilennya obrazu kazkovoho personazhu [Stimulation of creative abilities of teenagers by means of embodiment of an image of a fairy-tale character ]. Lyal'ka yak znak, obraz, funktsiya: Mater. 
vseukr. nauk.-prakt. konf. «Druhi Marka Hrushevs'koho chytannya» / za red. O.S. Naydena. Kyyiv. : VD «Stylos», 2010. Pp. 200-204.

7. Frayt O. Fortepianni al'bomy ta tsykly ukrayins'kykh kompozytoriv dlya ditey: istoriya $i$ suchasnist' [Piano albums and cycles of Ukrainian composers for children: history and modernity]. Drohobych : Vydavnytstvo DDPU im. I. Franka. 2010. 94 p.

8. Chen Kai, Shcholokova Olga. Methodological basis of the future musicians-educators performance-educational activity. Intellectual Archive. Toronto: Shiny Word.Corp. (Canada). 2018. (May/June). Vol. 7. No. 3. PP. 94-104.

9. Shcholokova Olga, Ding Yun. Pedagogical Principles of Young Pupils' Music Culture Formation in Piano Teaching Process. Intellectual Archive. 2015. Vol. 4. No. 6 (November). Toronto : Shiny Word Corp., 2015. Pp. 160-169.

\section{Translation of the Title, Abstract and References to the Author's Language}

\section{УДК 37.018.54:78].016:[37.015.31:7](043.3)}

Ляо Бінь. Організація експериментальної роботи 3 формування музичноестетичної компетентності підлітків у закладах позашкільної мистецької освіти.

У статті наголошується, що стан сучасної мистецької освіти України і Китаю вимагає впровадження в практику музичного навчання учнів позашкільних закладів освіти нових методик, спрямованих на формування їх музично-естетичної компетентності. Представлена поетапна методика охоплює фортепіанну підготовку учнів підліткового віку у двох площинах: виконавській і художньо-теоретичній, що передбачає наявність трьох етапів (організаційно-орієнтаційного, інтелектуальнопоглиблюючого і творчо-збагачувального).

Основним призначенням першого (організаційно-орієнтаційного) етапу навчання стало набуття у підлітків позитивної мотивації до музично-естетичної діяльності та розширенні тезаурусу музичних знань.

Другий (інтелектуально-поглиблюючий) етап був спрямований на теоретичне та практичне освоєння музичних знань з метою формування у підлітків музично-естетичної компетентності, наповнення музично-інтонаційного словника, розширення музичноестетичного світогляду, активізації емоційних вражень, співставлення власних переживань з художньо-образним змістом твору, накопичення музичного тезаурусу та музично-виконавського досвіду.

Третій (творчо-збагачувальний) етап спрямовувався на розвиток здатності до жанрово-стильового втілення інтерпретаційних задумів, творчого оцінювання музичних явищ на основі прийнятої у музичному мистецтві системи цінностей.

Ключові слова: музично-естетична-компетентність, позашкільні мистецькі заклади, фортепіанна підготовка, підлітки, методика фортепіанного навчання.

\section{Лimepamypa}

1. Бруднов А. К. Система воспитания и дополнительного образования детей: от идей до внедрения Педагогика. 1999. № 6. С. 26-32. 
2. Жалсйко Д. М. Три погляди та три прочитання: порівняльний аналіз виконавських версій фортепіанного циклу «Кітч-музика» В. Сильвестрова. Вісник ХДАДМ. 2014. № 8. С. 16-21.

3. Мистецька освіта у вимірах сучасності: проблеми теорії та практики. Наукова школа Ольги Пилипівни Щолокової : [монографія] / ред.: О. М. Полатайко; Нац. пед. унт ім. М.П. Драгоманова. Дніпропетровськ : Адверта, 2014. 305 с.

4. Ни Ин. Создание «Китайской мечты» для фортепиано. На пути к утверждению роли восточной цивилизации. Интервью с Чжан Чжао. Музыка. 2015. № 3. С. 32-34.

5. Петько Л. В. Лінгвосоціокультурний підхід у вивченні американської новорічної пісні «Jingle Bells» // Topical issues of pedagogy: Collective monograph. Editoria di Modena, Roma, Italy. 2019. Pp. 31-58.

6. Петько Л. В. Стимулювання творчих здібностей підлітків засобами втілення образу казкового персонажу. Лялька як знак, образ, функція: Матер. всеукр. наук.-практ. конф. «Другі Марка Грушевського читання» / за ред. О. С. Найдена. Київ. : ВД «Стилос», 2010. C. 200-204.

7. Фрайт О. Фортепіанні альбоми та цикли українських композиторів для дітей: історія і сучасність. Дрогобич : Видавництво ДДПУ ім. І. Франка. 2010. 94 с.

8. Chen Kai, Shcholokova Olga. Methodological basis of the future musicians-educators performance-educational activity. Intellectual Archive. - Toronto: Shiny Word.Corp. (Canada). 2018. (May/June). Vol. 7. No. 3. PP. 94-104.

9. Shcholokova Olga, Ding Yun. Pedagogical Principles of Young Pupils' Music Culture Formation in Piano Teaching Process. Intellectual Archive. 2015. Volume 4. No. 6 (November). Toronto : Shiny Word Corp., 2015. Pp. 160-169. 
DOI: 10.32370/IA_2021_09_15

\title{
Social Dance as a Phenomenon of Modern Dance Practice
}

\author{
Zhuravlova Anastasia Volodymyrivna, \\ lecturer of the department of choreographic art \\ Kiev National University of Culture and Arts, \\ Kiev, Ukraine
}

The article is devoted to the study of social dance as a phenomenon of modern dance practice.

It is emphasized that in modern culture there is an increase in interest in social dance, which necessitates a theoretical understanding of this phenomenon in particular and dance culture in general from the standpoint of modern science, because at the moment its level does not correspond to the degree of practical interest in social dance.

It is stated that for most world civilizations, dance in general and social dance in particular, is one of the most important expressions of their worldview, which represents both historical and contemporary cultural values. And forms of movement illuminate and define gender, shape personal and group identity, and reflect and define political and religious status and aesthetic values.

Thanks to advances in the media, social dance is now one of the most popular pastimes in the world, combining dance forms of past centuries with new ones, such as hip-hop and contact improvisations.

The study found that the phenomenon of social dance in the context of dance practice in the XXI century. is an organic combination of elements of various areas of dance culture with the culture of modern society, as well as the promotion of philosophical and ideological paradigm of freedom of movement and communication in dance.

Keywords: social dance, phenomenon, dance practice, improvisation, bodily-spatial event.

Актуальність дослідження. Танець займає важливе місце в соціальній структурі всіх культур протягом всієї історії людства. Зазвичай танець визначається як спосіб людського вираження засобами руху або особливий художній рух, оснований на виразних рухах людського тіла, проте, не зважаючи на те, що рух дійсно є його фундаментальною особливістю, танець не варто зводити виключно до руху. У ряді теоретичних визначень танець позиціонується як свідомий спосіб ритмічних рухів тіла у визначеному обмеженому просторі, проте такі спортивно-кінезіологічні або художні теорії танцю зазвичай не враховують багато символічних аспектів танцю. У багатьох випадках вони зводять танець до його фізичного компоненту з точки зору естетично досконалої ритмічної фізичної активності і не акцентують на багатьох ролях та значеннях, які танець має у суспільстві, в якому виникає та існує. Враховуючи вищесказане, актуальним та важливим стає дослідження танцю як частини соціального життя та культурної практики. 
В сучасній культурі спостерігається підвищення інтересу до соціального танцю, що зумовлює необхідність теоретичного осмислення цього феномену зокрема i танцювальної культури в цілому з позицій сучасної гуманітаристики, оскільки на даний момент його рівень не відповідає ступеню практичного інтересу до оволодіння соціальним танцем.

Безумовно, соціальний танець не є абсолютно новим предметом дослідження, проте окремі питання не отримали відповідного висвітлення в просторі вітчизняної академічної школи.

Аналіз публікацій. На початку XXI ст. завдяки трансформаційним процесам, що відбувалися в світовій танцювальній практиці, в західному академічному просторі значно активізувалося наукове вивчення різноманітних аспектів соціального танцю як складного культурно-мистецького феномену сучасності. Для прикладу назвемо наукові публікації Дж. Скінер «Соціальний танець для успішної старості» [15], Б. КоенСтретунер «Соціальний танець: контекст та дефініція» («Social Dance: Contexts and Definitions») [8], дослідження К. Кноле «Сальса, Меренга, Бачара та їх величезний бум» («Salsa, Merengue, Bachata und deren enormer Boom») [9], С. Слоат «Карибський танець від Абакуа до ука: як дух формує ідентичність» («Caribbean Dance from Abakuá to Zouk: How Movement Shapes Identity») [16] та ін. Аналіз публікацій засвідчив і посилення наукового інтересу серед вітчизняних дослідників. Серед інших назвемо статті Р. Гриценюка «Соціальні танці в соціокультурному просторі XXI ст.: спортивнозмагальний аспект» [2], Д. Погибіль «Педагогіка соціального танцю в сучасному соціокультурному просторі» [5], О. Плахотнюка «Квітнесенція соціальних танців» [6] та ін.

У сучасному академічному вимірі дослідження соціального танцю позиціонують важливим інструментом для розуміння людства, оскільки спостереження та аналіз танцю в його культурному контексті $є$ центральним для вивчення культур і життєво важливим аспектом в міжкультурному дослідженні.

Дане дослідження спрямоване на розширення вітчизняної теоретичної бази для аналізу феномену соціального танцю.

Мета статті - визначити та розкрити різноманітні значення і нюанси соціального танцю в сучасних суспільствах. 
Виклад основного матеріалу. 3 антропологічної точки зору танець можна визначити як культурну практику і як соціальний ритуал, відповідно до якого танець розглядається як засіб естетичного задоволення і засіб встановлення зв'язків та певної структури в суспільстві [13, p. 132]. Танець як соціальний ритуал можна розглядати крізь призму символічних аспектів конкретної культури та процесів ідентифікації i диференціації через значення, як він виробляє для людей цієї культури.

Танець завжди має певне значення, що залежить від соціального середовища, в якому він з'являється: наприклад, якщо у певному танці партнер повертає партнерку під рукою, на денонативному рівні цей рух передає значення повороту, а на більш широкому культурному, конотативному рівні цей рух може свідчити про чоловіче домінування та жіноче підкорення, тобто про шовінізм і патріархальну культуру. Проте в окремих випадках цей рух може бути ознакою жіночого домінування і чоловічого преклоніння жінці, що означає матріархальну структуру суспільства $[12$, р. 7]. К. Сакс наголошує, що танець в усі часи і в усіх культурах - від магії та анамізму палеолітичної людини до корінних релігій африканських народів і племен; від давніх цивілізацій Сходу та давніх суспільства середньовічної Свропи до західних капіталістичних суспільств - тісно пов'язаний з життям конкретного суспільства, оскільки він є формою спілкування та невід'ємною частиною відтворення соціальної системи [14, p. 43]. За Бурдьє танець як особлива мова є соціально-історичним явищем, що залежить від простору і часу, в якому він існує, а також від тогочасних провладних структур [7, p. 4]. Т. Полхемус зазначає, що суспільства створюють танці і що танець насправді $є$ «метафізикою культури», тому, що культура конкретного суспільства втілена у формах матеріальної і фізичної культури, а остання також стилізована і схематизована у формі танцю $[11$, p. 8].

Науковці наголошують, що в процесі дослідження ролі танцю в соціальному житті доцільно виокремлювати два напрями: соціальний (побутовий) танець, який змінюється відповідно до культурним традиціям різних епох та аматорське хореографічне мистецтво, яке є дозвіллєвою діяльністю. Відповідно на сучасному етапі танець розвивається в напрямках професійного мистецтва, аматорського мистецтва та соціального танцю, який деякі дослідники називають тимчасовою категорією, оскільки кожна історична доба та соціальна група впливали на створення певного напряму танцю, відображалися на його стилістичних особливостях і створювали власні музично- 
хореографічні форми. Так, наприклад, В. Нікітін акцентує на існуванні певного протиставлення соціального танцю і танцю як виду мистецтва, що, на його думку, викликано семантичними причинами, оскільки один і той самий термін «сучасний танець» має різні значення. Дослідник наголошує, що головна відмінність полягає в тому, що аналіз танцю, який тісно пов'язаний з життям людського суспільства, дає зрозуміти, що в цій ролі танець існував протягом всієї історії людства, а аналіз танцю як виду мистецтва дає змогу точно визначити історичні межі зародження та розвитку того чи інщого напрямку, стилю або жанру танцювального мистецтва [3, с. 293].

На думку О. Плахотнюка, соціальний танець доцільно розглядати як «різновид парних танців, упорядкованих та кодифікованих для доступного виконавства та вивчення, що виокремились 3 бального та фольклорного танцю» [6, с. 29]; «нове сприйняття танцювальної культури сьогодення, основною якої є легке і невимушене танцювання будь-якого виду хореографії, що спрямоване на задоволення естетичних, соціальних й комунікативних задоволень потреб людини, а не заради професійного виконавства чи спортивних досягнень» $[6,29]$.

Зауважимо, що в академічному вимірі наразі не існує єдиного загальноприйнятого визначення поняття «соціальний танець», а його багатозначність вимагають обов'язкового уточнення який саме аспект танцювального феномену є предметом дослідження. Характерною тенденцією в країнах пострадянського простору $\epsilon$ ототожнення багатьма науковцями терміну «соціальний танець» та «побутовий танець» (підгрунтям цієї тенденції є переклад англомовного терміну «social», безпосередньо пов'язаного з соціумом та спілкуванням), що визначається як танець, що виконується в побуті для задоволення самих танцюристів. Проте, на думку Н. Осінцевої, подібне трактування не є коректним, оскільки дає підстави відносити до соціального танцю і народні танці, які також безпосередньо пов'язані з спілкуванням людей в певному соціумі у вільний час для особистого задоволення [4, с. 783].

Поділяючи думку дослідниці щодо неправомірності ототожнення термінів, які описують соціальний танець та необхідності виявлення його однозначного терміну, не зважаючи на протиріччя інтерпретації, що полягають в складності визначення генези даного явища як не лише продовження напряму який існував раніше, а нового явища у танцювальній культурі, яке наразі знаходиться на стадії активного становлення, у даному 
дослідженні розглядаємо соціальний танець як танець, що має соціальну функцію і контекст, а характерними ознаками є відсутність постійного танцювального партнера, варіативність послідовності рухів, імпровізація, об’єднання людей, які належить до різних культур та забезпечення їх комунікативної взаємодії і взаєморозуміння.

На думку французького філософа А. Бад’ю, танець - це єдине мистецтво, яке підкорене простору [1, с. 70]. У випадку соціального танцю сучасності, кожна пара, яка танцює на спільних майданчиках, створює власний простір для діалогу, результатом якого є створення унікальної невеличкої події, завжди нової і неповторної, що «призупиняє час і розгортається у просторі» [1, с. 68], відповідно партнери створюють специфічну тілесно-просторову подію.

Джерелами імпровізації в соціальному танці є онтологічна сутність танцю, яка спрямовує його до свободи:

- від усталених та/або кодифікованих танцювальних фігур;

- від професійних знань та високої /віртуозної техніки виконання;

- від соціальної ієрархії [4, с. 793].

Дослідники розглядають соціальний танець як транскультурну генезу святкового ритуального дійства, унікальну ритуалізовану практику сучасності, що, на відміну від багатьох інших явищ сучасної масової культури, має не північноамериканське, а південноамериканське та африканське походження i наголошують на тому, що походження ритмів соціального танцю безпосередньо пов'язано з революційним духом та карнавальною традицією, тобто традицією святкового ритуального дійства, неочевидною метою якого є мирне співіснування всіх культурних шарів [10, с. 9-10].

Важливими особливостями соціального танцю є те, що:

- соціальний танець не має автора хореографії, оскільки він створений людьми і саме зміни в укладі людського життя призводять до виникнення та популяризації нових рухів та фігур;

- соціальний танець репрезентує своєрідну картину переплетіння, протистояння, симбіозу та синтезу традицій, культур, ритмів, образів та міфів;

- функціональне призначення соціального танцю полягає в об'єднанні суспільства (за Б. Кохен-Стратінер одним з багатьох призначень соціального танцю $є$ зібрати всіх разом для того, щоб щось відсвяткувати) [8, р. 122] з метою святкування; 
- у соціальному танці відсутній постійний танцювальний партнер (як, наприклад, в бальному або спортивному бальному танці), що зумовлено прагненням до розширення комунікативної взаємодії;

- важливим аспектом соціального танцю є імпровізація - завдяки відсутності жорстко структурованої послідовності рухів танцюристи можуть виконувати різноманітні танцювальні варіації.

Соціальний танець характеризується унікальним процесом творчого вираження в реальній формі, оскільки позбавлений завдання створити твір мистецтва, не ставить за мету створення певного результату творчості, що несе певну ідею та створюється хореографом-творцем або групою хореографів.

Висновки. Цінності культури втілюються (в прямому і переносному сенсі) в їі танцювальних формах, і для більшості світових цивілізацій танець загалом і соціальний танець зокрема, є одним із найбільш важливих виразників їх світогляду, що репрезентує як історичні, так і сучасні культурні цінності. А форми руху освітлюють та визначають гендер, формують особисту і групову ідентичність, а також відображають і визначають політичній і релігійний статус та естетичні цінності.

Завдяки досягненням в галузі засобів масової інформації соціальний танець наразі $\epsilon$ одним із найбільш популярних розваг людей в усьому світі, поєднавши танцювальні форми минулих століть з новими, такими як хіп-хоп та контактна імпровізація.

Дослідження виявило, що феномен соціального танцю в контексті танцювальної практики XXI ст. полягає в органічному поєднанні елементів найрізноманітніших напрямів танцювальної культури 3 культурою сучасного суспільства, а також популяризації філософсько-світоглядної парадигми свободи руху та спілкування в танці.

\section{References}

1. Badiou, A. (2014). A small guide to aesthetics. St. Petersburg: Publishing House of the European University at St. Petersburg.

2. Gritsenyuk, R. A. (2020). Social dances in the socio-cultural space of the XXI century: sports and competitive aspect. Art notes, Issue 38, pp. 79-84.

3. Nikitin, V. Yu. (2014). Dance as a socio-cultural phenomenon. Three faces of Terpsichore. MGUKI newspaper, no. 6, pp. 292-298.

4. Osintseva, N. V. (2021). Philosophical understanding of modern social dance. Diploma, no 4, pp. 780-794. 
5. Pogubil D. O. (2013). Pedagogy of social dance in the modern socio-cultural space. Scientific journal of NPU named after MP Drahomanov. Series 14: Theory and methods of art education, Issue 15, pp. 173-177. 28-37.

6. Plahotniuk, O. (2018). The flowering of social dances. Dance studios, Issue. 1, pp.

7. Bourdieu, P. (1994). Language and Symbolic Power. Cambridge: Polity Press

8. Cohen-Stratyner, B. (2001). Social Dance: Contexts and Definitions. Dance Research Journal, Issue 33, pp. 121-124.

9. Knolle, C. (2008). Salsa, Merengue, Bachata und deren enormer Boom. Dissertation Dr. Phil. Wien. DOI: 10.25365/thesis.3197.

10. Lisina, L. (2012). Ontology of the cultural influence dance as a ritual. Context and reflection: philosophy about the world and man, no. 2-3, pp. 9-19.

11. Polhemus, T. (1993). Dance, Gender and Culture. In: Helen Thomas (ed.), Dance, Gender and Culture. London: Macmillan, pp. 3-15.

12. Pusnik, M. (2010). Introduction: Dance as Social Lifeand Cultural Practice. Antropological notebooks, Issue 16 (3), pp. 5-8.

13. Radcliffe-Brown, A. R. (1994). Struktura in funkcija v primitivni družbi [Structure and Function in Primitive Society]. Ljubljana: ŠKUC, Filozofska fakulteta.

14. Sachs, C. (1994). World History of the Dance. New York: W. W. Norton \& Company.

15. Skinner, J. (2013). Social Dance for Successful Aging. Anthropology \& Aging Quarterly, Vol. 34, Issue 1, pp. 18-29.

16. Sloat, S. (2005). Caribbean Dance from Abakuá to Zouk: How Movement Shapes Identity. Gainesville : University Press of Florida.

\section{Translation of the References to the author's language}

\section{Список використаних джерел}

1. Бадью А. Малое руководство по инэстетике / пер. с фр. Д. Ардамацкой, А. Магуна. Санкт-Петербург: издательствово Европейского университета в СанктПетербурге, 2014. 156 с.

2. Гриценюк Р. А. Соціальні танці в соціокультурному просторі XXI ст.: спортивно-змагальний аспект. Мистецтвознавчі записки: зб. наук. праць. 2020 Вип. 38 С. 79-84.

3. Никитин В. Ю. Танец как социокультурный феномен. Три лика Терпсихоры. Вестник МГУКИ. 2014. № 6. С. 292-298.

4. Осинцева Н .В. Филосовское осмысление современного социального танца. Грамота, 2021. № 4. С. 780-794. 
5. Погибіль Д. О. Педагогіка соціального танцю в сучасному соціокультурному просторі. Науковий часопис НПУ імені М. П. Драгоманова. Серія 14 : Теорія і методика мистецької освіти. 2013. Вип. 15. С. 173-177.

6. Плахотнюк О. Квітнесенція соціальних танців. Танцювальні студії : зб. наук. пр. 2018. Вип. 1. С. 28-37.

7. Bourdieu P. Language and Symbolic Power. Cambridge: Polity Press, 1994. 303 p.

8. Cohen-Stratyner B. Social Dance: Contexts and Definitions. Dance Research Journal. 2001. Issue 33. pp. 121-124.

9. Knolle C. Salsa, Merengue, Bachata und deren enormer Boom. Dissertation Dr. Phil. Wien, 2008. DOI: 10.25365/thesis.3197.

10. Lisina L. Ontology of the cultural influence dance as a ritual. Контекст и рефлексия: философия о мире и человеке. 2012. № 2-3. С. 9-19.

11. Polhemus T. Dance, Gender and Culture. In: Helen Thomas (ed.), Dance, Gender and Culture. London: Macmillan, 1993. pp. 3-15.

12. Pusnik M. Introduction: Dance as Social Lifeand Cultural Practice. Antropological notebooks. 2010. Issue 16 (3). pp. 5-8.

13. Radcliffe-Brown A. R. Struktura in funkcija v primitivni družbi [Structure and Function in Primitive Society]. Ljubljana: ŠKUC, Filozofska fakulteta, 1994. 244 p. $469 \mathrm{p}$.

14. Sachs C. World History of the Dance. New York: W. W. Norton \& Company, 1994.

15. Skinner J. Social Dance for Successful Aging. Anthropology \& Aging Quarterly. 2013. Vol. 34. Issue 1. pp. 18-29.

16. Sloat S. Caribbean Dance from Abakuá to Zouk: How Movement Shapes Identity. Gainesville : University Press of Florida, 2005. 442 p. 
DOI: 10.32370/IA_2021_09_16

\title{
Specificity of M. Novak's Activity in the Context of the Development of Ukrainian Film Production in the Countries of North America
}

\author{
Turchak Lesya Ivanovna \\ PhD in Art History, Associate Professor, \\ Kiev National University of Culture and Arts, \\ Kiev, Ukraine
}

The article examines the film production activities of one of the leading figures of socio-political and cultural life of the Ukrainian community in New York and Los Angeles in the mid-twentieth century. The activity of M. Novak in the context of the attempt to develop the Ukrainian film industry in order to outline the national identity is studied. The peculiarities of M. Novak's professional and public activity in the context of the specifics of the Ukrainian diaspora in Canada and the USA are revealed and his contribution to the Ukrainian film industry abroad is clarified.

The study found that the common semantic and stylistic basis of films of the Ukrainian diaspora in Canada and the United States in the 20-60's of the twentieth century. became the baggage of Ukrainian culture of their creators, the traditions of domestic cinema, in which they worked before emigrating, as well as the general attitude to the preservation of traditions of Ukrainian culture of the diaspora in North America, typical of the second wave of emigration in general.

Through his own activities in the field of film production and distribution of documentary and feature films, M. Novak contributed to the nation-building dialogue and the actualization of the communicative efficiency of world Ukrainians.

Keywords: M. Novak, Ukrainian film production, diaspora, USA, Canada, film producer, distribution, public activity.

Актуальність дослідження. Сучасні дослідники розглядають діаспору як невід'ємну складову нації, завданням якої є збереження української ідентичності, традицій, культури, мистецтва. Хвилі еміграції, які проходили в Україні сприяли тому, що велика кількість талановитих людей змушена була залишити батьківщину. Справу свого життя вони продовжили в еміграції, тим самим не лише зберегли культурні традиції а і продовжили їх, сприяли популяризації української культури в різних країнах Європи та Америки. Українське кіно в діаспорі розвивалось, видозмінювалось, набуваючи нових форм і наповнюючись новими сенсами відповідно до національної специфіки та культурної традиції країни. Феномен емігрантського кіно як і культури в цілому відтворює ситуацію вибуху та породженої ним культурної дисгармонії, що згодом упорядковується, набуваючи рис нової знакової системи (за Ю. Лотманом).

Кінематографічна, громадська та культурна діяльність М. Новака в українській діаспорі Канади та Сполучених Штатів Америки в контексті специфіки процесу 
культурної асиміляції, взаємоінтеграції та привнесеної традиції породжує феномен, що викликає науковий інтерес.

Аналіз публікацій. Дослідження протягом останніх тридцяти років стали популярним науковим напрямом у світовій гуманітаристиці, що розвивається в нову перспективну академічну дисципліну.

Незважаючи на науковий інтерес до різноманітних аспектів діяльності представників української діаспори, вітчизняними дослідниками професійна, громадська та культурна діяльність М. Новака лишається недостатньо невисвітленою. Однією з небагатьох наукових публікацій, присвячених постаті М. Новака в контексті кіновиробництва в Новому Світі є стаття Ю. Мицика «Спроба створення українського Голлівуду (Микола Новак)» [15]. Г. Карась в статті «Особливості менеджменту української музичної культури в діаспорі» [8] розглядає діяльність М. Новака як талановитого організатора театральних вистав, концертів, демонстрацій українських музичних фільмів. Окремі аспекти діяльності М. Новака висвітлено у наукових статтях, предметом дослідження яких став український закордонний кіноматограф першої половини XX ст. або творча діяльність відомих режисерів в еміграції, наприклад, публікації Л. Косаківської «Василь Авраменко - Іван Кавалерідзе: «кінодуель» через океан» [12], Р. Бучко та А. Дорошенка «Український закордонний кінематограф 19301945» [3], О. Ковальчук «Збереження та збагачення культурної спадщини українцями у США (кінець XIX - початок 40-х pp. XX ст.)» [10], I. Патрон «Кіноспадщина Юліана Дороша в контексті розвитку кіномистецтва на західноукраїнських землях у 20-30 роках ХХ століття» [18] та ін.

Мета статті - з'ясувати його внесок в українську кіноіндустрію за кордоном, виявити особливості професійної та громадської діяльності М. Новака в контексті специфіки української діаспори в Канаді та США.

Виклад основного матеріалу. Микола Новак народився 14 лютого 1902 р. у с. Мерешівка (Рогатинський повіт) у родині столяра, навчався в Рогатинській гімназії. В роки Першої світової війни юнак організував групу «Молода Січ», в яку входили тринадцять підлітків (прикладом для наслідування став український добровольчий легіон українських січових стрільців, що діяв у складі австро-угорської армії), в листопаді 1918 р., після проголошення Західноукраїнської народної республіки, вступив 
добровольцем до Української Галицької Армії, а після поразки в польсько-українській війні (1918-1919рр.), проводив активну пропагандистську діяльність серед українських вояків та вступив до лав Української військової організації (УВО), що сформувалася у 1920 р. Після демобілізації в 1926 р. М. Новак емігрував до Канади, поєднуючи громадсько-політичну діяльність (учасник Українського військового об'єднання) 3 роботою та захопленням театром (юнак брав участь у самодіяльному українському театрі) [9, с. 173].

У 1929 р. М. Новак переїхав до Сполучених Штатів Америки (м. Нью-Йорк), там продовжив громадсько-політичну діяльність, був одним із співорганізаторів Організації державного відродження України, перші осередки якої створені наприкінці 1920-х рр. під час перебування в Північній Америці голови Проводу українських націоналістів С. Коновальця. Головною метою організації, під час 1-го з’їзду в 1931 р., було затвердження фінансової підтримки та допомоги діяльності Українській військовій організації та Організації українських націоналістів, а згодом пріоритетним стало питання збереження національної ідентичності українців у Сполучених Штатах Америки [13, с. 235]. Діяльність М. Новака в межах організації як заступника їі голови зосереджувалася передусім на галузі театрального мистецтва. Зокрема, Г. Карась стверджує, що М. Новаком наприкінці 1920-х рр. - початку 1930-х рр. було організовано концерти танцюристів В. Авраменка, хорові концерти О. Кошиця, а також концертні виступи відомого соліста-баритона П. Ординського і скрипаля та композитора Р. Придаткевича [8, c. 178].

У 1931 р. М. Новак став менеджером однієї 3 шкіл українського танцю В. Авраменка та співорганізатором Ювілейного Комітету Українських Танцюристів, створеного до річниці діяльності українських танцюристів на території Північної Америки, що відбувся 25 квітня 1931 р. М. Новаку було доручено перевірити рівень майстерності хореграфів у найбільших осередках української діаспори та запросити їх для участі у святковій виставі в Метрополітен Опера. Внаслідок його організаційної діяльності в нью-йоркському концерті, метою якого було ознайомлення представників різних національностей з українським хореографічним мистецтвом, брали участь 500 танцюристів та 100 співаків, а зібрані кошти були передані В. Авраменко для подальшої популяризації української культури [17, с. 116-117]. 
Ю. Мицик наголошує, що саме тоді у М. Новака виник задум виробництва українських кінострічок [15, с. 43]. Натхненний результатами українського кіновиробництва в США та Канаді, ініційованого пастором Іваном Яцентієм (земляком М. Новака), зокрема німою кінострічкою «Галичина» (1929 р.), у 1934 р. М. Новак намагався запустити зйомки фільму про відомих серед української громади бойовиків ОУН, учасників однієї з найгучніших акцій націоналістичного підпілля на території міжвоєнної Польщі Василя Біласа та Дмитра Данилишина, розстріляних польською владою 23 грудня 1932 р. після чергового пограбування державного поштового відділення в містечку Городок біля Львова, проте через ряд об’єктивних причин реалізувати задум не вдалося. Р. Бучко наголошує, що зібраний М. Новаком матеріал став основою для написання п’єси, постановку якої йому вдалося здійснити лише в 1940х рр. після переїзду в м. Лос-Анджелес [3, с. 281].

Першим проектом М. Новака як кінопродуцента в Новому Світі стала кінострічка «Наталка Полтавка» (Наталка - співачка Метрополітен-Опери Т. Сабанієва, Петро - Д. Кріона, Микола - Ф. Свистун, Терпелиха - О. Діброва, Возний - М. Водяний та ін.). Дослідники стверджують, що 3 ініціативою екранізувати найвідомішу п’єсу I. Котляревського до М. Новака звернувся пропагандист української народної культури в цілому та українського танцю зокрема, відомий хореограф, засновник мережі танцювальних шкіл у містах Канади та США Василь Авраменко, у творчому доробку якого на той час було кілька німих фільмів [15, с. 43]. Як стверджує С. Мензелевський, В. Авраменко передусім прагнув «прославити українську культуру в Північній Америці поза локальним діаспорним контекстом» [14] та врятувати українську культуру від асиміляції. Його мета безсумнівно відповідала прагненням М. Новака на шляху до державного відродження України.

26 травня 1936 р. М. Новаком було організовано корпорацію першого звукового фільму «Наталка Полтавка» «Авраменко Філм Продакшн Інкорпорейтед», яку очолив М. Бойчук, а членами комітету були активні учасники Організації державного відродження України (М. Новак обіймав посаду секретаря), а за місяць до того започатковано спеціальний журнал «призначений українській фільмовій і балетній справі та народному житті» часопис «Промінь», основними призначеннями якого були заохочення потенційних інвесторів, популяризація майбутньої стрічки серед української громади 
Північної Америки та чітке формулювання головного «меседжу» фільму. Редактор часопису $€$. Скоцко наголошував на тому, що значення кінострічки передусім було культурно-політичним, оскільки представлені українській громаді в США та Канаді українські радянські фільми - це позбавлена національного духу «російськобольшевицька пропаганда» [19, p. 701]. Проте, дослідники наголошують на відсутності бажання у представників антибільшовицьких митців співпрацювати, наприклад, С. Мензелевський стверджує, що О. Кошиць, відомий український диригент i композитор, відмовився працювати над фільмом В. Авраменка, тому вирішено було запросити К. Швєдова, викладача Московської консерваторії. У доповіді «Як повстала українська фільма «Наталка Полтавка» М. Новак також акцентує на конфлікті О. Кошиця 3 хореографом, його негативній рецензії, надруковані у газеті «Свобода», а також на тому, що режисером стрічки став американський режисер Е. Улмер, «бувший асистент славного на ввесь світ театрального режисера Рейнгардта» [4]. Варто зазначити, що М. Новак також був задіяний у кінознімальному процесі як актор (Landlord). В одному 3 інтерв'ю Е. Улмер стверджує, що кошти на кіновиробництво (понад 18000 доларів) були зібрані членами Спілки мийщиків вікон в Нью-Йорку, які заздалегідь продавали білети на кіносеанси, а на знімальний майданчик приїздили діти зі своїми костюмами з усієї країни для виконання танцювальних номерів [19, p. 701].

Прем'єрний показ кінофільму українською мовою (з субтитрами англійською) відбувся в нью-йоркському кінотеатрі «Венеція» (7-ма авеню) 25 грудня 1936 р. Незважаючи на неабиякий інтерес серед глядачів Сполучених Штатів Америки (кінострічку було показано в найбільших осередках української діаспори - Буфало, Бостон, Чікаго, Філадельфія, Детройт та ін.) і Канади (з березня 1937 р. фільм показано в Клівленді, Едмонтоні, Торонто, Саскауні, Вінніпезі), а також в цілому досить схвальні рецензії на кінострічку в періодичних виданнях (лише окремі сцени та танцювальні номери були розкритиковані режисером $Є$. Деславом та О. Кошицем), фільм провалився у прокаті через невдалу дистриб'юторську стратегію та замалі інвестиції в рекламу. $3 \mathrm{i}$ спогадів М. Новака дізнаємося, про особливості дистрибуції кінострічки в містах Канади: «Крім летючок різних, афішів, оголошень в пресі, найняли ми фармера з білими кониками, збудували на його санях «українську хату», а на хату начепляли різні великі реклами, попросили дві дівчини, які через мікрофони голосили кожного дня по полудні 
про прем’єру фільму «Наталка Полтавка» [7, с. 232]. На заваді популяризації української кінострічки в Новому Світі стала і зовнішня політика Радянського союзу. 3 метою нівелювання «націоналістичного» впливу серед української громади в США радянською владою було ініційовано екранізацію опери М. Лисенка «Наталка Полтавка» на кіностудії «Українфільм» (режисер І. Кавалерідзе, Наталка - К. Осмяловська, Микола С. Шкурат, Петро - М. Платонов) та прем’єрного показу першої кіноопери українського кіномистецтва практично одночасно з версією кінокорпорації М. Новака в США (на початку лютого 1937 р. корпорацією «Амкіно» фільм було випущено в прокат в кінотеатрі «Рузвельт») [7, с. 165]. На думку М. Новака, яку він висловив на нараді членів корпорації, дистрибуція радянської версії «Наталки Полтавки» - саботаж Москви, задуманий з метою «вбити наш бізнес» [17, с. 153]. Як наслідок внутрішніх розбіжностей між членами студії «Авраменко фільм» корпорація розділилася на дві групи: перша, очолена В. Авраменком, утворила корпорацію «Укрфільм» та розпочала зйомки фільму «Запорожець за Дунаєм», а друга - фільму «Маруся» за твором М. Старицького (невдовзі після прем’єри В. Авраменко викупив права на показ кінострічки на території Північної Америки) [3, с. 280].

М. Новак у складі другої групи розпочав роботу над екранізацією п’єси «Ой не ходи, Грицю, на вечорниці» на кошти української громади, залучивши до співпраці виключно провідних українських діячів культури і мистецтва діаспори США та Канади: Л. Булгакова (режисер), О. Кошиця (композитор, керівник хорової музики, диригент хору та фахівець з етнографіï), Р. Придаткевича (композитор оркестрового супроводу та диригент оркестру), А. Кистя та В. Кедровського (автори сценарію), Г. Кириченка (диригент); акторів: С. Мельник - Маруся, М. Стегницького - Микола, П. Чорнюка Хома, М. Скоробогача - Дмитро, Н. Троїцьку - Галина, С. Доню - Дарина, Г. Троян Оксана, а також активістів $з$ діаспори. М. Новак зіграв епізодичну роль Потапа, батька Марійки. Кінострічка «Маруся», на думку дослідників, «значно перевищила «Наталку» 3 мистецького боку» [15, с. 44], а завдяки більш вдалій дистриб'юторській стратегії мала неабиякий успіх у прокаті, проте без сумніву конкурувати з художніми фільмами американського виробництва не могла.

Дослідники кінематографу наголошують, що рівень конкурентоздатності конкретної кінематографії залежить від трьох груп факторів: стан, постановка та 
ідеологія кіносправи; тип та особливості зовнішнього соціального контексту; характер взаємодії кінематографу з зовнішнім громадським середовищем [5, с. 98]. Розуміючи, що з багатьох об’єктивних і суб'єктивних причин, у тому числі обмеженість глядацької аудиторії за етнічним показником, недостатнє фінансування (художні фільми «Наталка Полтавка» та «Маруся» були зняті власним коштом українських емігрантів), втручання з боку радянської влади та ін., М. Новак сфокусувався на створенні документальних фільмів.

Завдяки організаційним здібностям М. Новака спілкою В. Авраменка було озвучено фільм «Галичина», «Гуцульщина», завершено зйомки документального фільму «Трагедія Карпатської України» режисера К. Лисюка, присвяченого темі боротьби українців Закарпаття за незалежність (кошти з показу фільму в містах США та Канади були призначені на зйомки короткометражних кінострічок з життя української еміграції та завершення фільму «Тріумф українського танцю» В. Авраменка) [2, с. 6], а також «вдалий документальний кінорепортаж» [9, с. 173] про Перший Конгрес Українців Америки (липень 1940 р.). Кінострічка «Галичина» І. Яцентія, відзнята в 1934 р. частково в Рогатинщині, була призначена для ознайомлення глядачів США з пам'ятними місцями української землі (Княжа гора, церква Святого Юра, Театр Стадника, Волоська Церква та ін.) та розкриття етапів визвольної боротьби українського народу. Німий фільм було перемонтовано та озвучено за методом кінотехніка С. Федіва, що полягав у магнетичному озвучуванні. Дослідники наголошують, що ця стрічка, разом із фільмом «Мистецький документ з гуцульського весілля», знятого І. Яцентією в 1936 р. «викуплені Миколою Новаком, який у 1950-х роках активно демонстрував ці кінотвори в українських осередках у США та Канади» [3, с. 255]. Б. Берест, відомий історик діаспори, до переліку німих кінофільмів, які були озвучені С. Федівим для фірми М. Новака додає фільм «Гуцульщина», відзнятий Ю. Дорошем в 1938 р. [1, с. 195].

На думку В. Ковпак, кінематографічна діяльність українців в еміграції стала потужним соціокомунікативним каналом інформаційного простору, унікальним «концентрованим багатоступеневим кодом репрезентації різних інформаційних моделей медіакартини світу» [11, с. 23].

У 1941 р. М. Новак здійснив дистрибуцію «фільмової драми із життя закарпатських українців» «Забутий край» (перша назва «Марійка Невірниця», режисер 
В. Ванчура, автор сценарію І. Ольбрахт, К. Нови), прем’єра якої в Сполучених Штатах Америки відбулася в Нью-Йорку 1 листопада 1941 р. Варто зазначити, що фільм було знято в 1934 р. на Закарпатті в селах біля Чорної Ріки чеською фільмовою компанією «Славія фільм», головну роль виконав А. Кість, а решту - місцеві жителі, включно 3 виконавицею головної жіночої ролі Г. Шкелебей [16, с. 4]. Силами спілки кінострічку субтитровано англійською мовою [3, с. 281].

У 1943 р. М. Новак переїздить до Лос-Анджелесу, ставши співзасновником місцевого українського культурного осередку, працював над написанням кіносценаріїв («Ілюзії Москви») та статей на тему кіномистецтва і життя в Голлівуді до журналів і часописів [9, с. 173].

Активний «організатор українського життя в Лос-Анджелесі» [6, с. 8] М. Новак пропагував національну культуру за кордоном. Зокрема був одним із засновників та президентом Українського культурного центру (Лос-Анджелес, Каліфорнія; перша назва Український соціальний центр), заснований в 1944 р. для пропаганди соціального та культурного життя українців та надання взаємодопомоги, а також членом Ради мерії 3 міжнародних візитів. Ним було організовано численні концертні виступи капели бандуристів Г. Китастого, ансамблю «Калина», хорів під керівництвом Р. Кичмарського, В. Чайковського, сольних виступів інструменталістів та багатьох зірок української опери [17, с. 494-498]. У 1956 р. М. Новаком засновано український театр «Київ» (ЛосАнджелес), в якому 27 жовтня того ж року проведено концерт провідних солістівінструменталістів та оперних співаків з Сан-Франциско: І. Вовка, А. де Пом'ян, О. Задорожної-Акіншиної, В. Мартиненка, В. Чайковського та ін.

У 1979 р. надруковано спогади М. Новака «На сторожі України», присвячені українській еміграційній кінопродукції [17].

Висновки. Діяльність М. Новака в галузі кіноіндустрії отримала виявлення в контексті організації кінознімального процесу, надзвичайно активної продюсерської діяльності, дистрибуції українських кінострічок та пропагуванні української культури в країнах Північної Америки.

Дослідження виявило, що спільною основою виробництва художніх та документальних кінострічок, розвитку яких сприяв М. Новак, стали надбання української культури їх творців, традиції вітчизняного кіно, в якому вони працювали до 
від’їзду в еміграцію, а також загальна установка назбереження традицій української культури діаспори в Північній Америці, характерна для другої хвилі еміграції в цілому.

Власною діяльністю в галузі кіновиробництва та дистрибуції документальної і художньої кінопродукції, М. Новак посприяв забезпеченню націотворчого діалогу та актуалізації комунікативної ефективності світового українства.

\section{References}

1. Berest, B. (1964). History of Ukrainian cinema. New York.

2. Buchko, R. (1991). We know ours abroad. Movie screen news, no. 7, p. 6.

3. Buchko, R., Doroshenko, A. (2016). Ukrainian foreign cinema 1930-1945. History of Ukrainian cinema 6 in 5 volumes Vol. 2: 1930-1945.

4. Reviews about the first Ukrainian sound film "Natalka Poltavka". December 1936 TsDAVO of Ukraine. F. 4465. Op. 1. Ref. 1022. Arc. 4.

5. Zhabskiy, M. I. (2011). Factors of competitiveness of national cinematographies. VGIK Bulletin, no. 10, pp. 96-110.

6. Seidler, N. "Will you forgive me, my mother-in-law...": life and creative paths in the homeland and abroad of Ukrainian Ivan Ovechko. URL:

http://library.mlt.gov.ua/images/kraieznavstvo_Melitopolia/Natalia_Zaidler.pdf

7. Kavaleridze, I. P. (2017). Memoirs. Drama. Journalism / compiler S. Menzelevsky. Kyiv: Oleksandr Dovzhenko National Center.

8. Karas, G. V. (2016). Features of management of Ukrainian musical culture in the diaspora. Carpathian region, no. 1 (8), pp. 177-184.

9. Book of artists and figures of Ukrainian culture (1954). The first meeting of Ukrainian artists from Canada and America with citizenship. Toronto.

10. Kovalchuk, O. (2005). Preservation and enrichment of cultural heritage by Ukrainians in the United States (late nineteenth - early 40's of the twentieth century.). Ukraine of the XX century: Culture, ideology, politics, Issue 9, pp. 753-773.

11. Kovpak, V. A. (2017). Information and communication activities of postwar Ukrainian emigration: the semantic matrix of the idea of the nation. Abstract of Ph.D. Zaporozhye : Classical Private University.

12. Kosakivska, L. (2003). Vasyl Avramenko - Ivan Kavaleridze: "film duel" across the ocean. Cinema Theater, no. 4, pp. 8-10.

13. Kucheruk, O. S. (2010). Organization of State Revival of Ukraine (ODVU). Encyclopedia of the History of Ukraine: Vol. 7. Kyiv: Naukova Dumka.

14. Menzelevsky, S. (2017). In the struggle for the "national film", or How Ukrainians made films in America. Ukrainian Pravda. May 23, 2017. URL : https://life.pravda.com.ua/culture/2017/05/23/224323/. 
15. Mytsyk, Y. (2020). Attempt to create Ukrainian Hollywood (Mykola Novak). Cinema, no. 2, pp. 43-44.

16. Novak, M. (1941). The forgotten land. Freedom. October 24, 1941. Part 246. P. 4.

17. Novak, M. (1979). On guard of Ukraine: own memories, historical materials, documents, correspondence, archive. Los Angeles, California: Published by the author.

18. Patron, I. (2018). Film heritage of Julian Dorosh in the context of the development of cinema in Western Ukraine in the 20-30s of the twentieth century. Scientific Bulletin of the IK Karpenko-Kary Kyiv National University of Theater, Film and Television, Issue 23, pp. 92100.

19. Gevinson, A. (Ed.). (1997). The 1911-1960: American Film Institute Catalog of Motion Pictures Produced in the United States: Within Our Gates: Ethnicity in American Feature Films / American Film Institute. University of California Press.

\section{Translation of the References to the Author's Language}

\section{Список використаних джерел}

1. Берест Б. Історія українського кіно. Нью-Йорк, 1964. 272 с.

2. Бучко Р. Знаймо наших за кордоном. Новини кіноекрану. 1991. № 7. С. 6

3. Бучко Р., Дорошенко А. Український закордонний кінематограф 1930-1945. Історія українського кіно 6 у 5-ти т. Т. 2 : 1930-1945 / голов. ред. Г. Скрипник; НАН України ; ІМФЕ ім. М .Т. Рильського. Київ, 2016. 448 с.

4. Відгуки про перший український звуковий фільм «Наталка Полтавка». Грудень 1936 р. ЦДАВО України. Ф. 4465. Оп. 1. Спр. 1022. Арк. 4.

5. Жабский М. И. Факторы конкурентоспособности национальных кинематографий. Вестник ВГИК. 2011. № 10. С. 96-110.

6. Зайдлер Н. «Чи простиш, моя ненько-вкраїно...»: життєві і творчі дороги на батьківщині та за їі межами українця Івана Овечка. URL : http://library.mlt.gov.ua/images/kraieznavstvo_Melitopolia/Natalia_Zaidler.pdf звернення : 12 червня 2021).

7. Кавалерідзе I. П. Мемуари. Драматургія. Публіцистика / упорядник С. Мензелевський. Київ : Національний Центр Олександра Довженка, 2017. 688 с.

8. Карась Г. В. Особливості менеджменту української музичної культури в діаспорі. Карпатський край. 2016. № 1 (8). С. 177-184.

9. Книга мистців і діячів української культури. Перша зустріч українських мистців Канади й Америки з громадянством. Торонто 1954. 316 с.

10. Ковальчук О. Збереження та збагачення культурної спадщини українцями у США (кінець XIX - початок 40-х рp. XX ст.). Україна XX ст.: Культура, ідеологія, політика. 2005. Вип. 9. С. 753-773. 
11. Ковпак В. А. Інформаційно-комунікаційна діяльність післявоєнної української еміграції: смислова матриця ідеї нації : автореферат дис. доктора наук із соціальних комунікацій : 27.00.01 / Класичний приватний університет. Запоріжжя, 2017. 40 с.

12. Косаківська Л. Василь Авраменко - Іван Кавалерідзе: «кінодуель» через океан. Кіно Театр. 2003. № 4. С. 8-10.

13. Кучерук О. С. Організація державного відродження України (ОДВУ). Енциклопедія історії України: Т. 7: Мі-О / редкол.: В. А. Смолій (голова) та ін. НАН України. Інститут історії України. Київ : Наукова думка, 2010. 728 с.

14. Мензелевский С. У боротьбі за «національну фільму», або Як українці знімали кіноопери в Америці. Українська правда. 23 травня 2017. URL: https://life.pravda.com.ua/culture/2017/05/23/224323/ (дата звернення : 12 червня 2021).

15. Мицик Ю. Спроба створення українського Голлівуду (Микола Новак). КіноТеатр. 2020. № 2. С. 43-44.

16. Новак М. Забутий край. Свобода. 24 жовтня 1941. Ч. 246. С. 4.

17. Новак М. На сторожі України: власні спогади, історичні матеріали, документи, листування, архів. Лос Анджелос; Каліфорнія: Накладом автора, 1979. 604 с.

18. Патрон I. Кіноспадщина Юліана Дороша в контексті розвитку кіномистецтва на західноукраїнських землях у 20-30 роках XX століття. Науковий вісник Київського національного університету театру, кіно і телебачення імені І. К. Карпенка-Карого. 2018. Вип. 23. С.92-100.

19. Gevinson A. (Ed.). The 1911-1960: American Film Institute Catalog of Motion Pictures Produced in the United States: Within Our Gates: Ethnicity in American Feature Films / American Film Institute. University of California Press, 1997. 1344 p. 


\section{Manuscript Guidelines}

1. All submitted papers must contain the Title, Name of author(s), Affiliation (if any), Abstract and List of References (Literature) written in English. The Abstract must count not less than 100 and not more than 300 words and must be the good representation of your article. Optionally paper may also contain this information duplicated in another language.

2. Font faces. Arial, Times, Times New Roman, Courier New and Helvetica.

3. Language. You may use any language for your paper text, however English is MUCH preferable.

4. Title. Font size - 16, bold. Position - central alignment.

5. The author's name. Font size - 14, bold. Position - central alignment.

6. The affiliation (your University etc). Font size - 14, regular (not bold). Position - left alignment.

7. The word "Abstract". Font size - 12, bold-italics. Position - central alignment.

8. The text of the abstract. Font size - 10, regular (not bold).

9. The word "Keywords" (if any). Font size - 10, bold. Position - left alignment.

10. The text of keywords (if any). Font size - 10, regular (not bold). Position - left alignment.

11. Text of article. Font size - 14. Position - left alignment or fully justified. Line spacing - 1.5 lines.

12. The word "References" (if any). Font size - 12, bold-italics. Position - central alignment.

13. The text of References (if any). Font size - 12, regular (not bold).

In all other cases please use your own good judgment or contact our Editorial Board.

\section{Where to find us}

The "IntellectualArchive" is distributed to major libraries across Canada and the US, including

Library of Congress, USA (http://lccn.loc.gov/cn2013300046 ) ,

Library and Archives Canada

(http://collectionscanada.gc.ca/ourl/res.php?url_ver=Z39.88-2004\&url_tim=2012-09-

05T01\%3A46\%3A54Z\&url_ctx_fmt=info\%3Aofi\%2Ffmt\%3Akev\%3Amtx\%3Actx\&rft_dat=40904933\&r

fr_id=info\%3Asid\%2Fcollectionscanada.gc.ca\%3Aamicus\&lang=eng) and others.

The references to articles published in the "IntellectualArchive" are available in the

Google Scholar, (http://scholar.google.ca/scholar?q=\%22IntellectualArchive\%22 ),

Arxiv.org (http://search.arxiv.org:8081/?query=\%22Intellectual\%20Archive\%22\&in= ),

WorldCat.org (https://www.worldcat.org/search?q=n2\%3A1929-4700\&qt=advanced \&dblist=638 ) ,

Academia.edu

(http://www.academia.edu/15503799/Light_diffraction_experiments_that_confirm_the_STOE_model_and

_reject_all_other_models )

The National Research Council (Italy) (http://data.cnr.it/data/cnr/individuo/rivista/ID658222 )

Наукова бібліотека of the University named after Dragomanov, Ukraine

(http://enpuir.npu.edu.ua/handle/123456789/7974?mode=full )

Google.com (https://www.google.ca/\#q=site:IntellectualArchive.com ) thousands of links etc. 